\title{
- Geology of the Gold Belt in the James River Basin Virginia
}

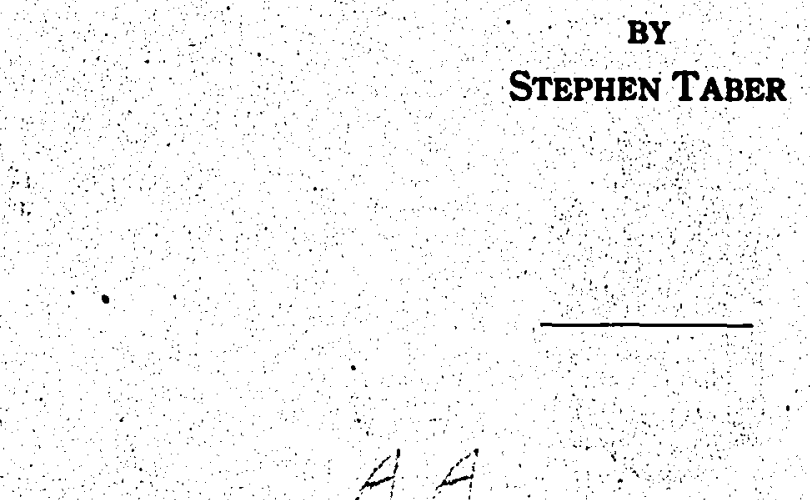

A Dissertation Presented to the Faculty of the University of Virginia an Partial Fulfilment of the Requirements for the Degree OF Doctor of PhILOSOPHY

CHARLOTTESVILLE

UNIVERGITY OF VIRGINIA

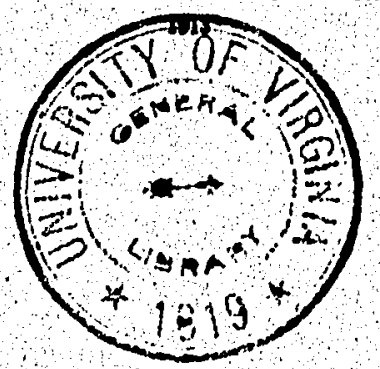





\section{CONTENTS}

Iltustritions $\ldots \ldots \ldots \ldots \ldots$ PAge

INTRODUCTION

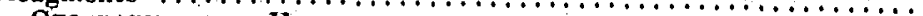

PTER I.GEOGRAPHY AND HISTORY $\ldots \ldots \ldots \ldots \ldots \ldots \ldots \ldots \ldots \ldots \ldots \ldots \ldots$

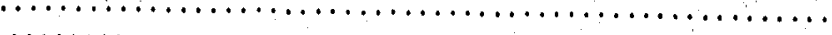

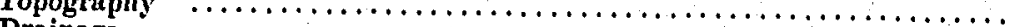

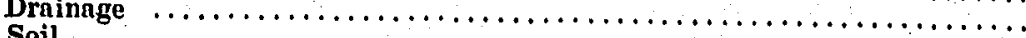

Soil

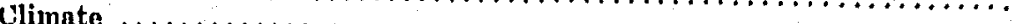

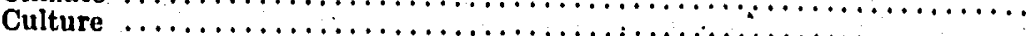

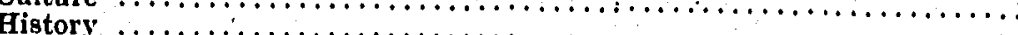

Production $\ldots \ldots \ldots \ldots \ldots \ldots$

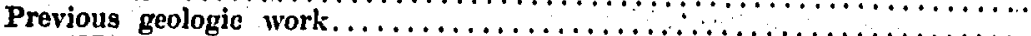

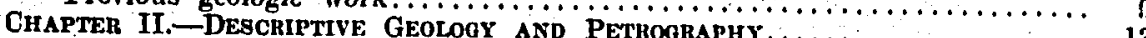

Introduction

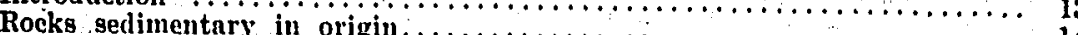

General clnssificntion origin. $\ldots \ldots \ldots \ldots \ldots \ldots \ldots \ldots \ldots \ldots \ldots \ldots \ldots \ldots \ldots$

.

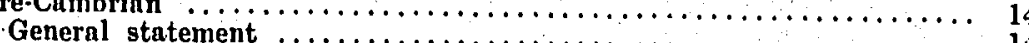

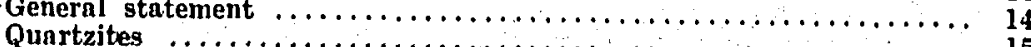

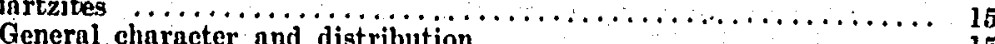

Details of

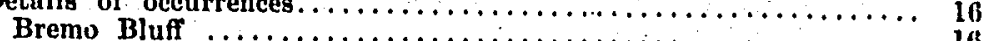

Tellurium mine $\ldots \ldots \ldots \ldots \ldots \ldots \ldots \ldots \ldots$

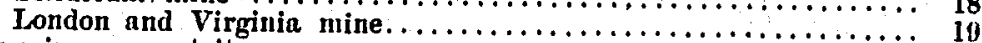

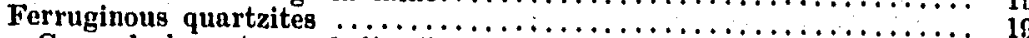

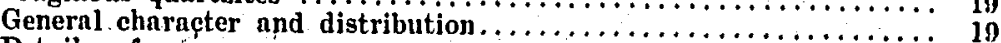

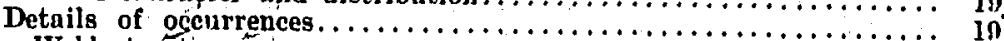

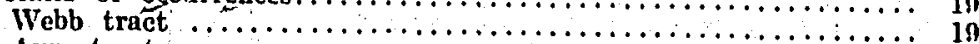

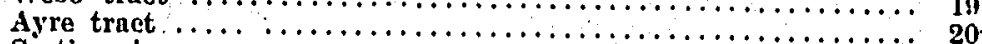

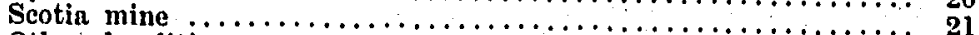

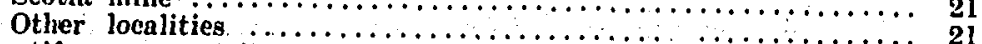

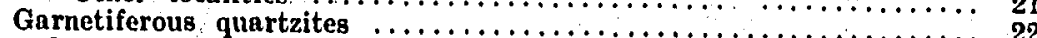

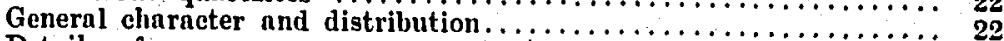

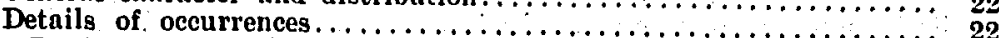

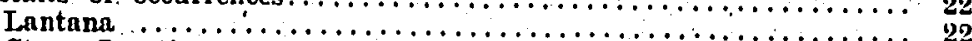

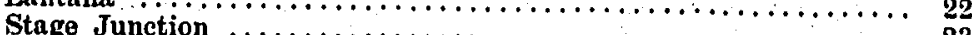

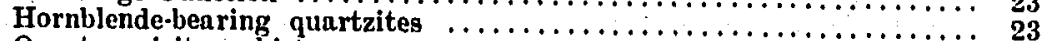

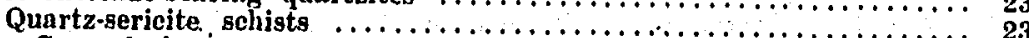

Generul character and distribution $\ldots \ldots \ldots \ldots \ldots$

Genesis

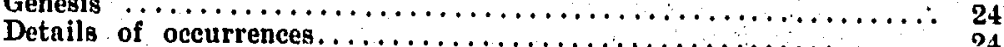

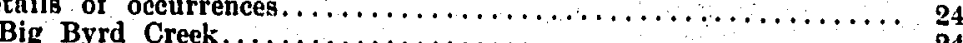

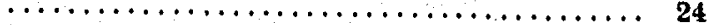

New Canton-Diliwy $\ldots \ldots \ldots \ldots \ldots \ldots \ldots \ldots \ldots \ldots \ldots \ldots \ldots \ldots \ldots$

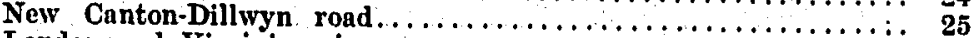

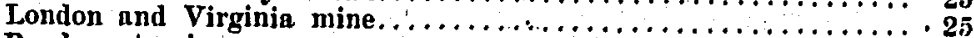

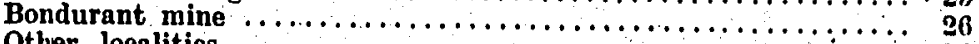

Cyanite schists

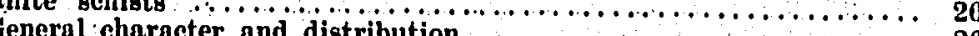

$\ldots \ldots \ldots \ldots \ldots \ldots \ldots \ldots \ldots \ldots \ldots+26$

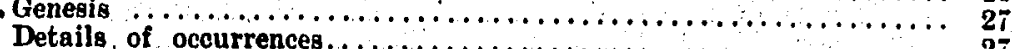

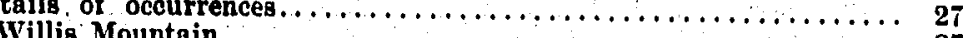

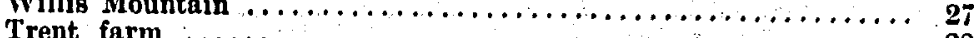

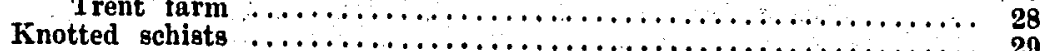

General character and distribution $\ldots \ldots \ldots \ldots \ldots \ldots \ldots \ldots \ldots \ldots \ldots \ldots$

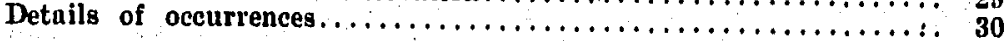




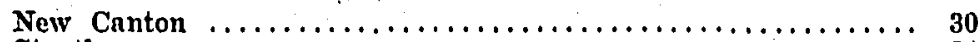

Strnthmore $\ldots \ldots \ldots \ldots \ldots \ldots \ldots \ldots \ldots \ldots \ldots \ldots \ldots \ldots \ldots \ldots \ldots \ldots \ldots \ldots \ldots \ldots \ldots \ldots,{ }_{34}$

The Tellurium schists............................ 34

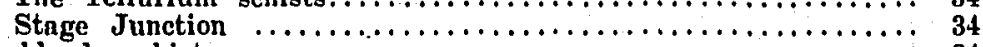

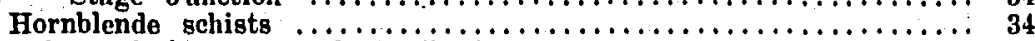

General charncter and distribution......................, 34

Details of occurrences............................... 35

New Canton $\ldots \ldots \ldots \ldots \ldots \ldots \ldots \ldots \ldots \ldots \ldots \ldots \ldots \ldots \ldots, 35$

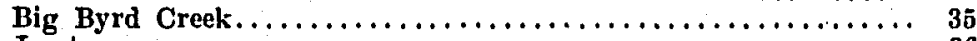

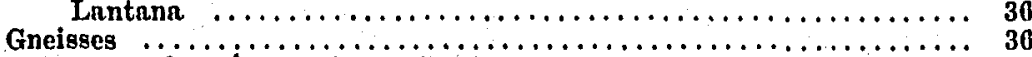

General character and distribution. $\ldots \ldots \ldots \ldots \ldots \ldots \ldots \ldots \ldots \ldots, 36 \ldots \ldots \ldots \ldots$

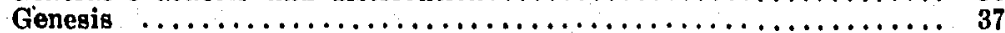

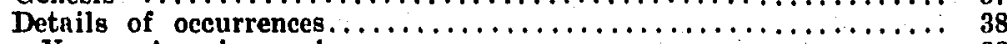

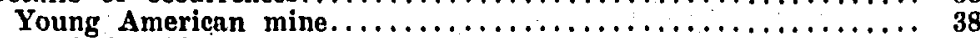

Bowles bridge $\ldots \ldots \ldots \ldots \ldots \ldots \ldots \ldots \ldots \ldots \ldots \ldots \ldots \ldots \ldots, 38$

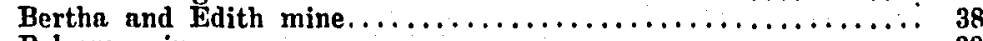

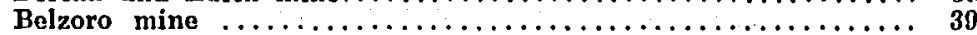

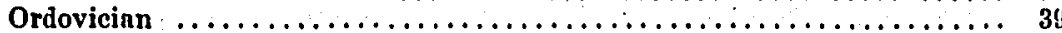

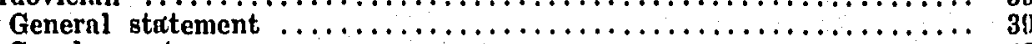

Conglomerate $\ldots \ldots \ldots \ldots \ldots \ldots \ldots \ldots \ldots \ldots \ldots \ldots \ldots \ldots \ldots \ldots \ldots \ldots,{ }_{40}$

General character and distribution $\ldots \ldots \ldots \ldots \ldots \ldots \ldots \ldots \ldots \ldots, 40$

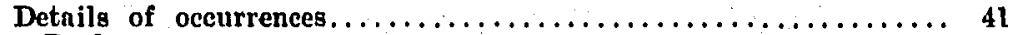

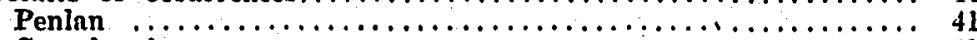

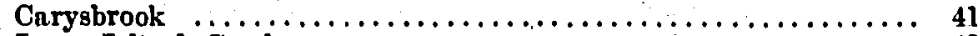

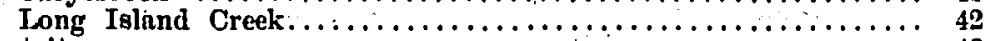

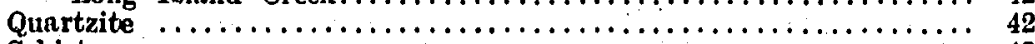

Schist $\ldots \ldots \ldots \ldots \ldots \ldots \ldots \ldots \ldots \ldots \ldots \ldots \ldots \ldots \ldots \ldots \ldots, 42$

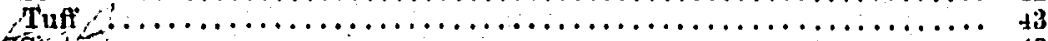

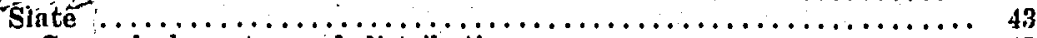

General character and distribution $. \ldots, \ldots \ldots \ldots, \ldots \ldots, \ldots \ldots, 48$

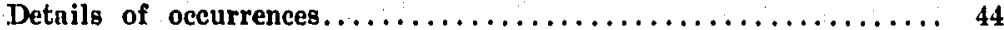

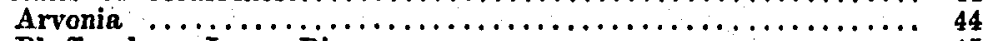

Bluffs along James River......................... 45

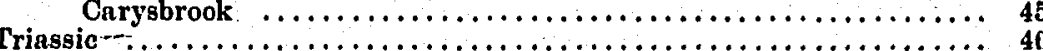

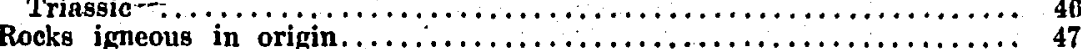

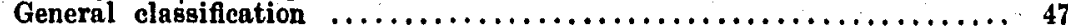

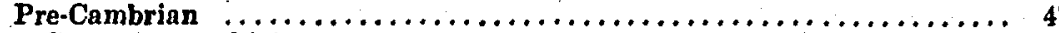

Greenstone schists ............................... 4

General character and distribution $\ldots \ldots \ldots \ldots \ldots \ldots \ldots \ldots \ldots \ldots, 47$

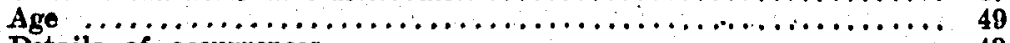

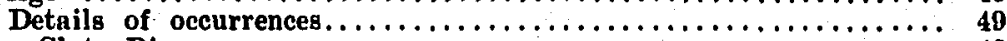

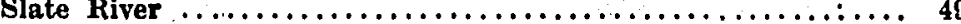

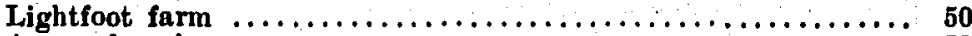

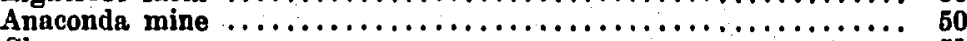

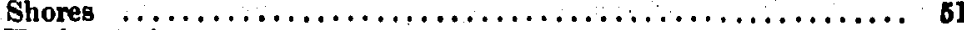

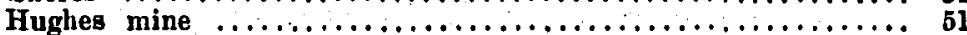

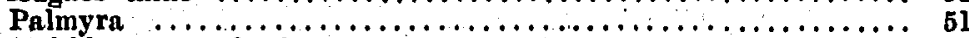

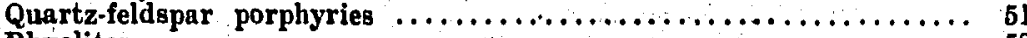

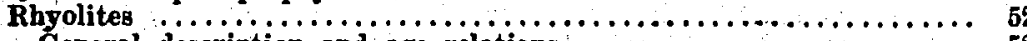

General description and age relations $\ldots \ldots \ldots \ldots \ldots \ldots \ldots \ldots \ldots \ldots, 52$

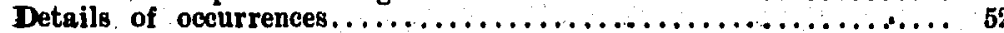

Bremo Bluff $\ldots \ldots \ldots \ldots \ldots \ldots \ldots \ldots \ldots \ldots \ldots \ldots \ldots \ldots \ldots \ldots \ldots \ldots, 52$

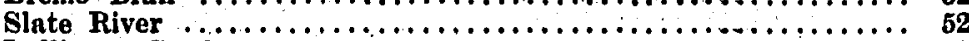

Ballinger Creek $\ldots \ldots \ldots \ldots \ldots \ldots \ldots \ldots \ldots \ldots \ldots \ldots \ldots \ldots \ldots, 52$

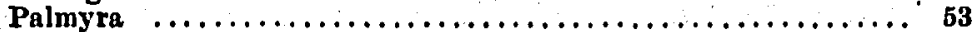

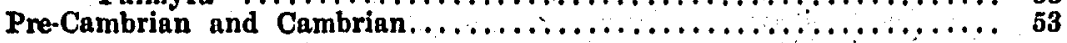


Granites, their associnted pegmatites, and hornblende schists........ Introductory statement $\ldots \ldots \ldots \ldots \ldots \ldots \ldots \ldots \ldots \ldots \ldots \ldots \ldots \ldots$

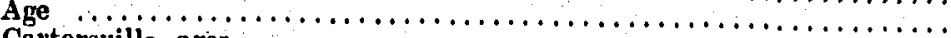

Cartersville aren..$\ldots \ldots \ldots \ldots \ldots \ldots \ldots \ldots \ldots \ldots \ldots \ldots \ldots \ldots \ldots$

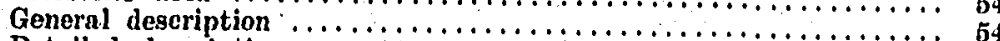

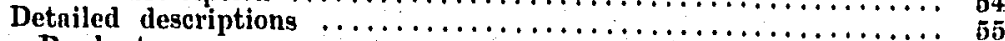

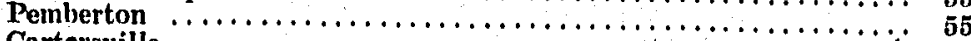

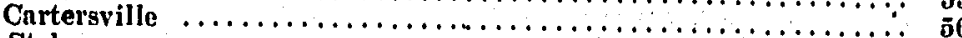

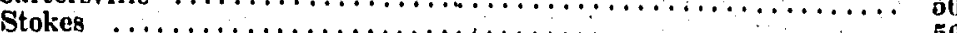

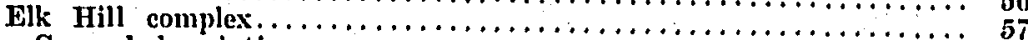

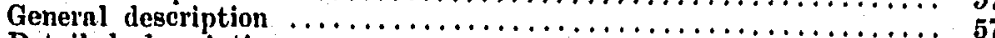

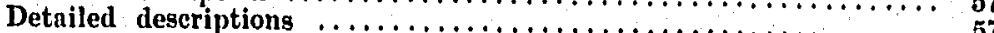

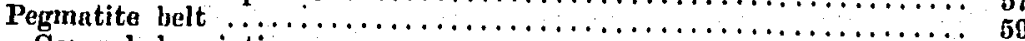

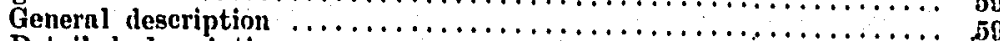

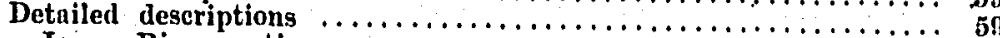

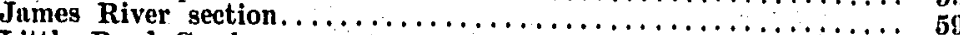

Little Byrd Creek...................................

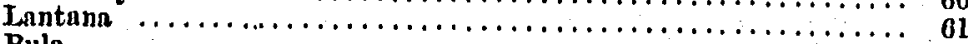

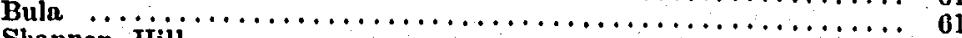

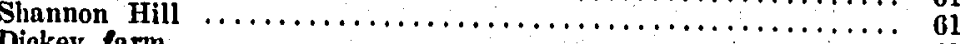

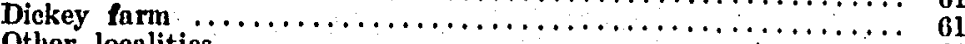

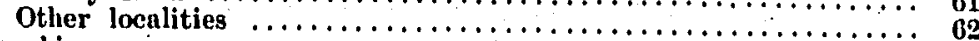

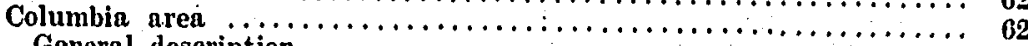

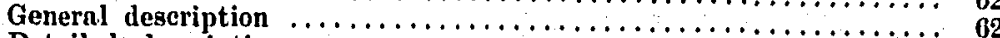

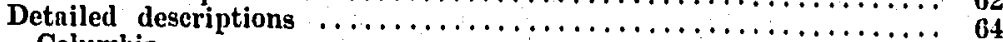

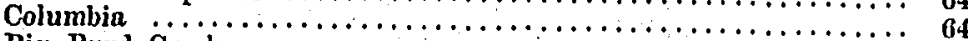

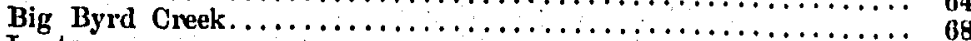

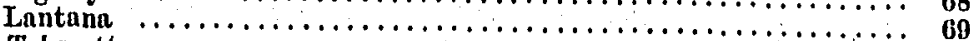

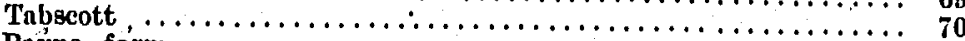

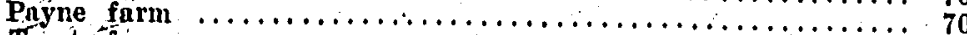

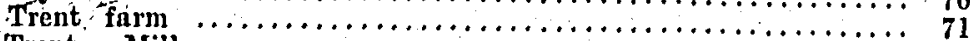

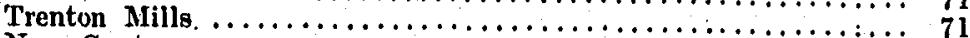

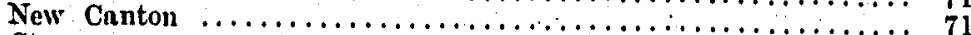

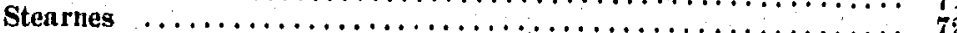

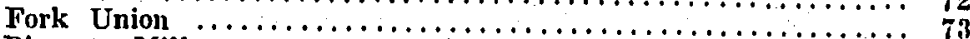

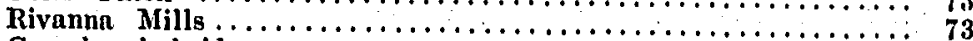

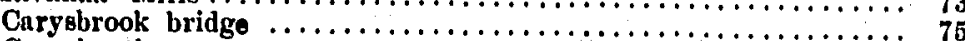

Carysbrook

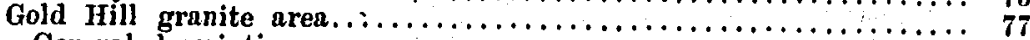

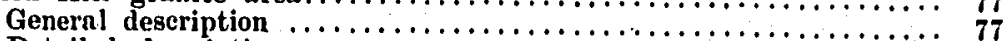

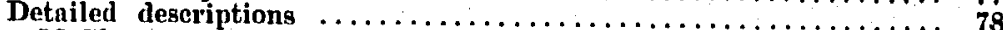

McGloam mine $\ldots \ldots \ldots \ldots \ldots \ldots \ldots \ldots \ldots \ldots \ldots \ldots \ldots \ldots \ldots \ldots, 78$

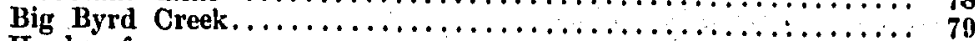

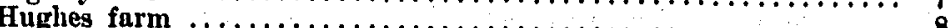

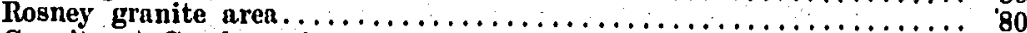

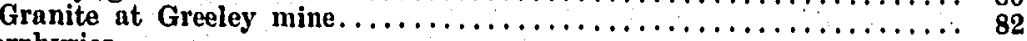

Porphyries ........................ ${ }_{82}^{82}$

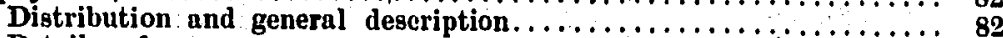

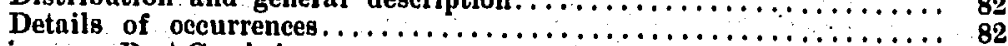

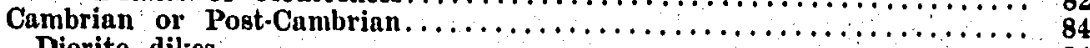

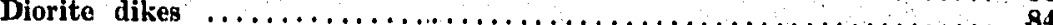

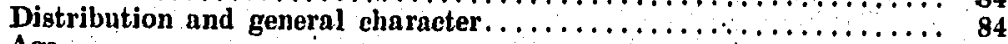

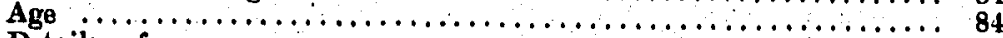

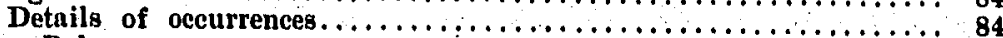

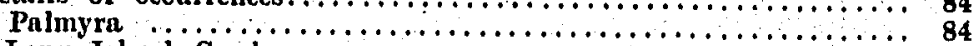

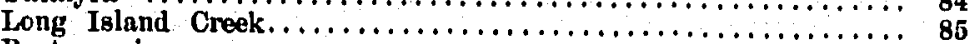

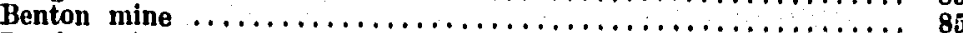

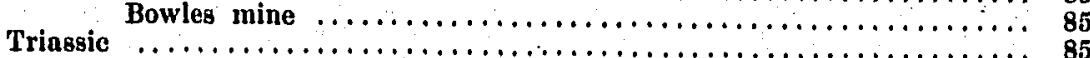


Dinbase dikes

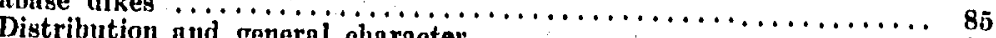

Details of occurrences chancter...................... 85

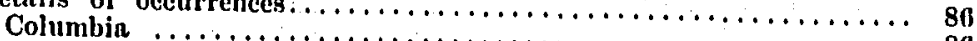

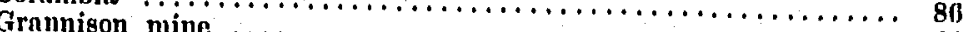

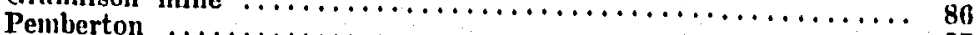

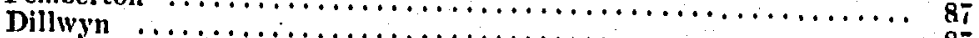

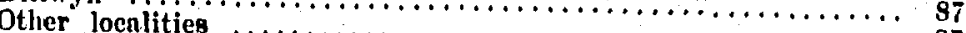

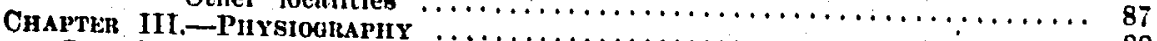

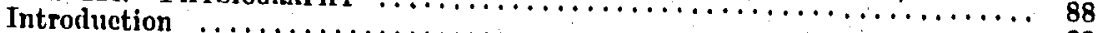

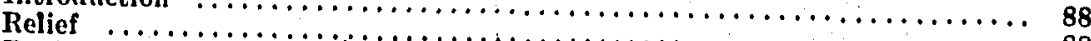

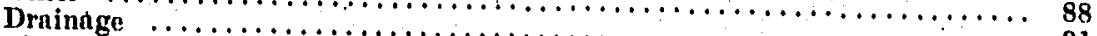

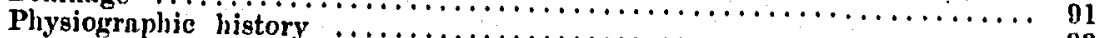

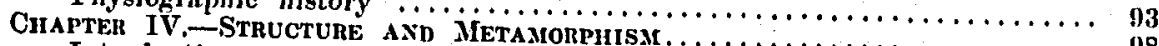

Introduction

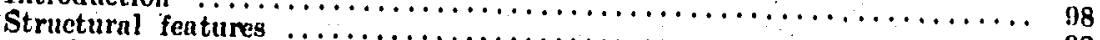

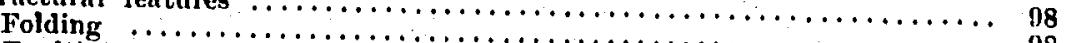

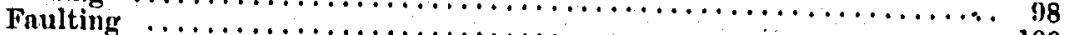

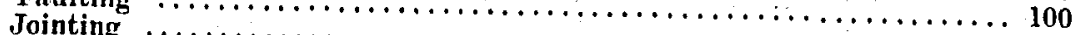

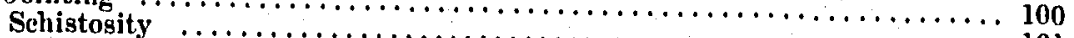

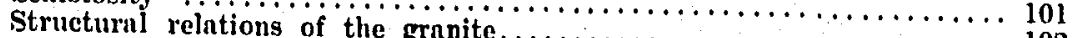

Relution of the hornblende selists to the granites $\ldots \ldots \ldots \ldots \ldots \ldots \ldots \ldots \ldots \ldots$
Metamorphic fentures

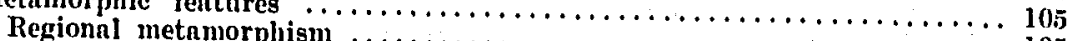

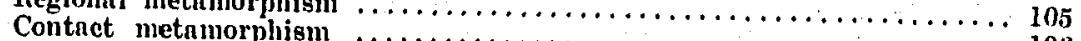

Introduction

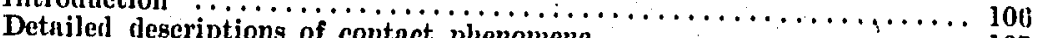

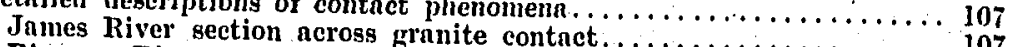

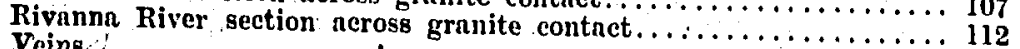

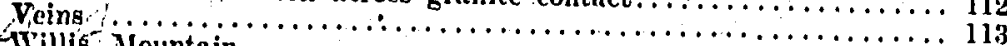

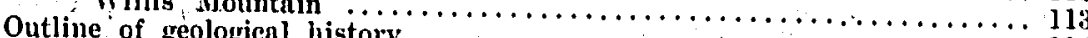

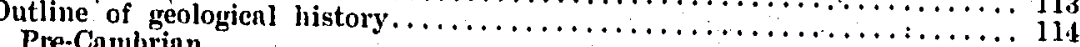

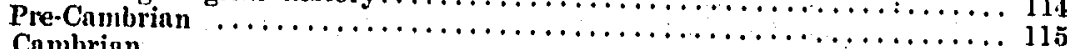

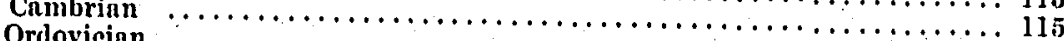

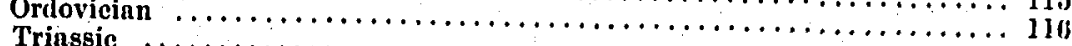

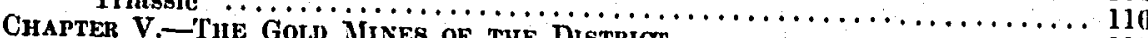

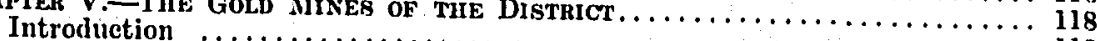

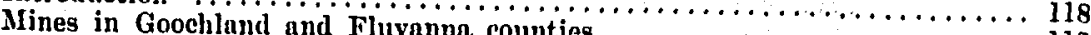

The Young American mine.

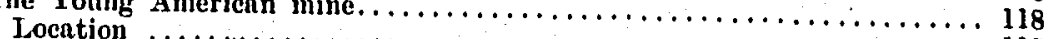

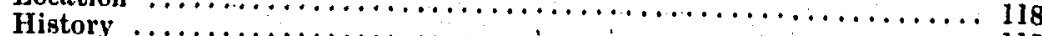

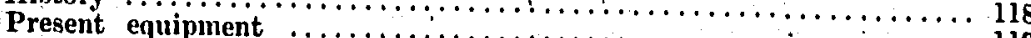

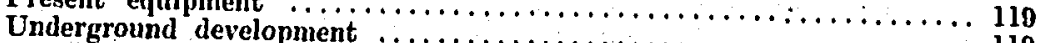

General deseription of geology $\ldots \ldots \ldots \ldots \ldots \ldots \ldots \ldots \ldots \ldots, \ldots \ldots \ldots$

Detailed description of

The Belzoro mine $\ldots \ldots \ldots \ldots \ldots \ldots \ldots \ldots \ldots \ldots \ldots \ldots$

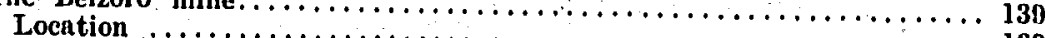

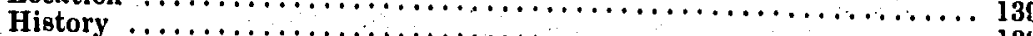

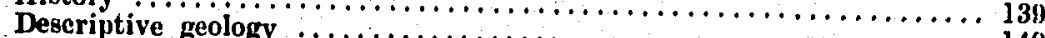

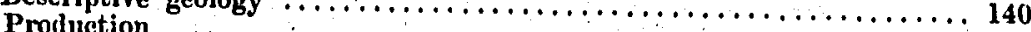

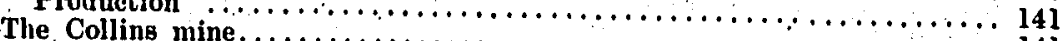

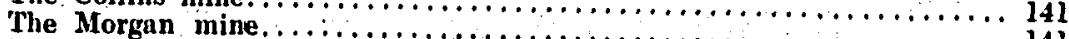

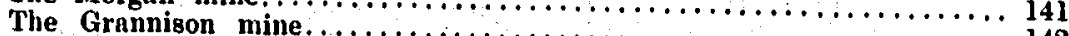

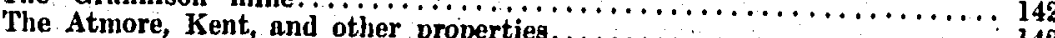

The Bertha and Edith mine prorties..................

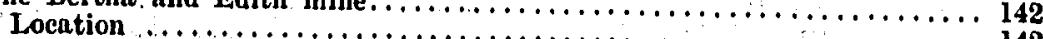

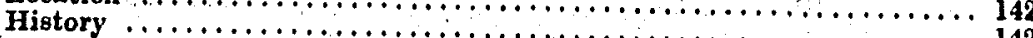


Description of veins and country rock. PAar

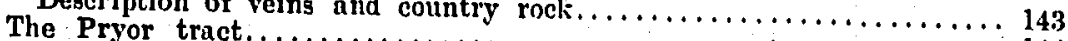

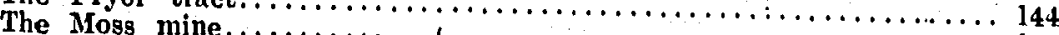

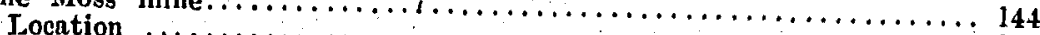

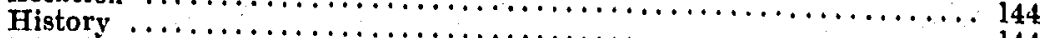

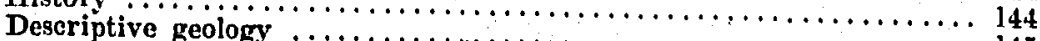

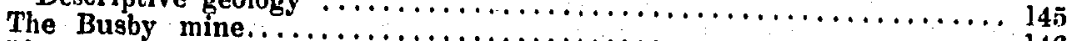

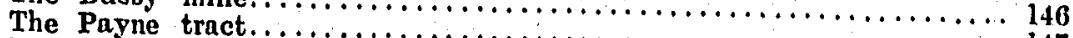

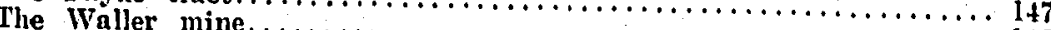

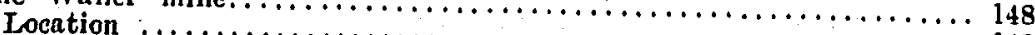

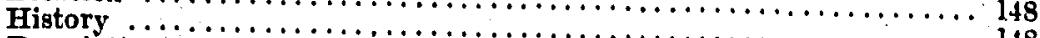

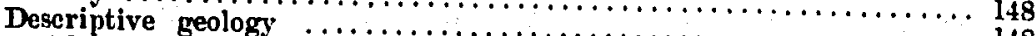

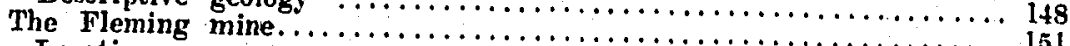

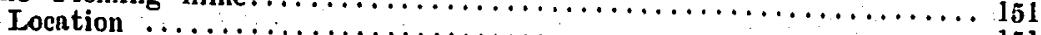

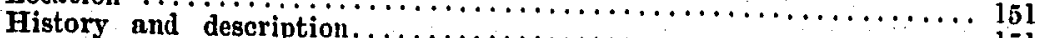

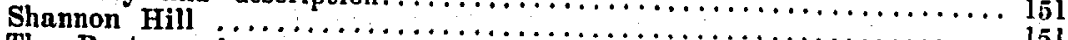

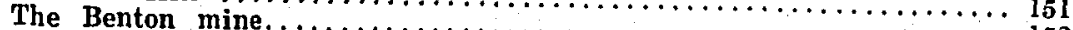

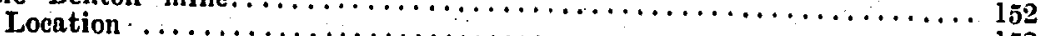

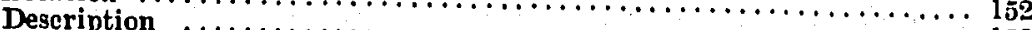

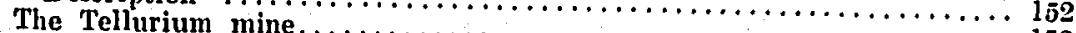

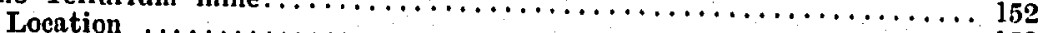

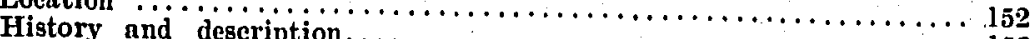

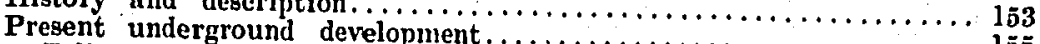

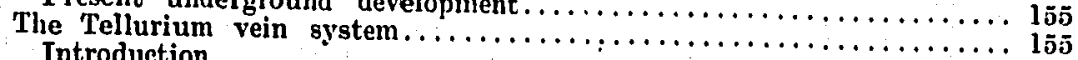

General description of veins and country rock $\ldots \ldots \ldots \ldots \ldots \ldots \ldots \ldots \ldots$

Detailed description of veins and wall rock $\ldots \ldots \ldots \ldots \ldots \ldots \ldots \ldots$

The Scotia mine

Locntion . mine.........

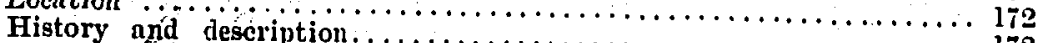

Gold prospects southwest of the

The Bowles mine.

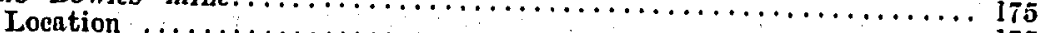

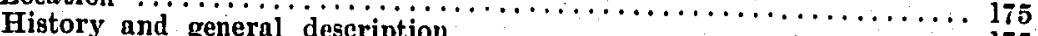

The Gold Hill vein system.

Introduction

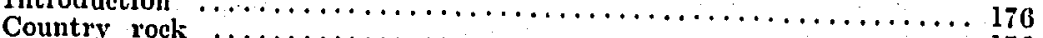

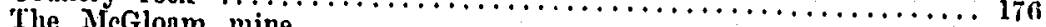

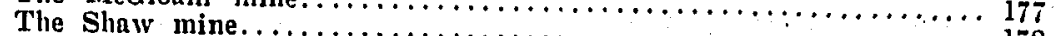

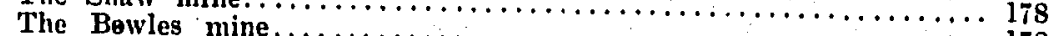

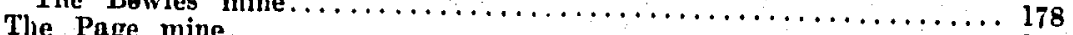

The Snead mine

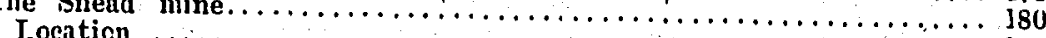

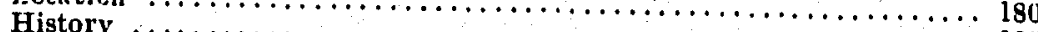

Geology

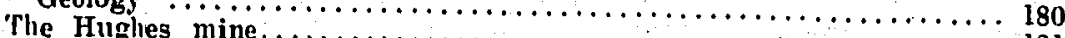

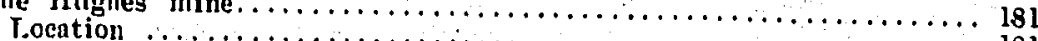

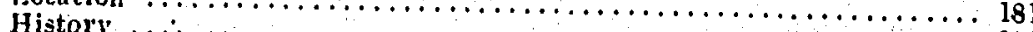

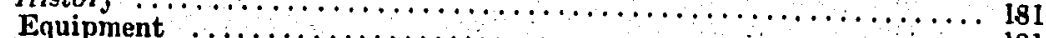

Underground development and d....................... 18

ription of veins.............. 189

Mines in Buckingham County

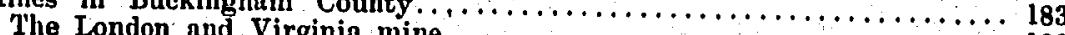

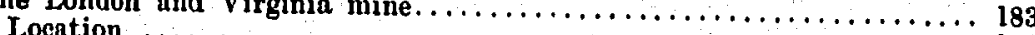

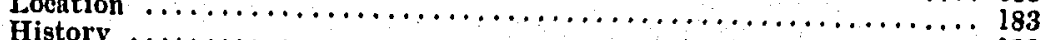

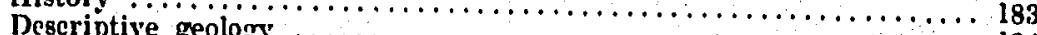

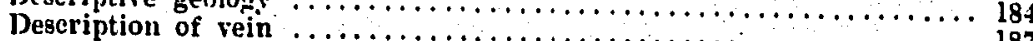




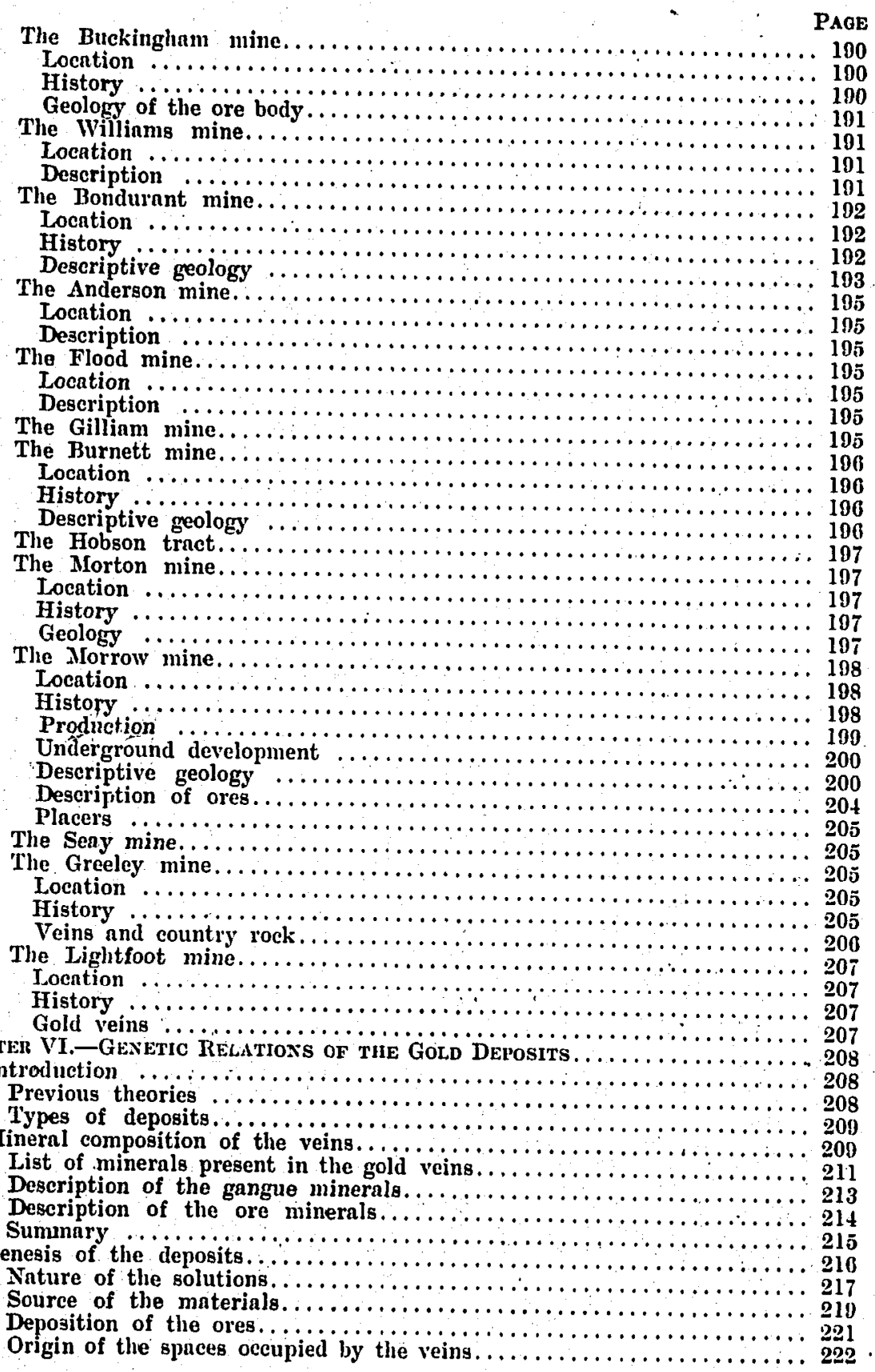




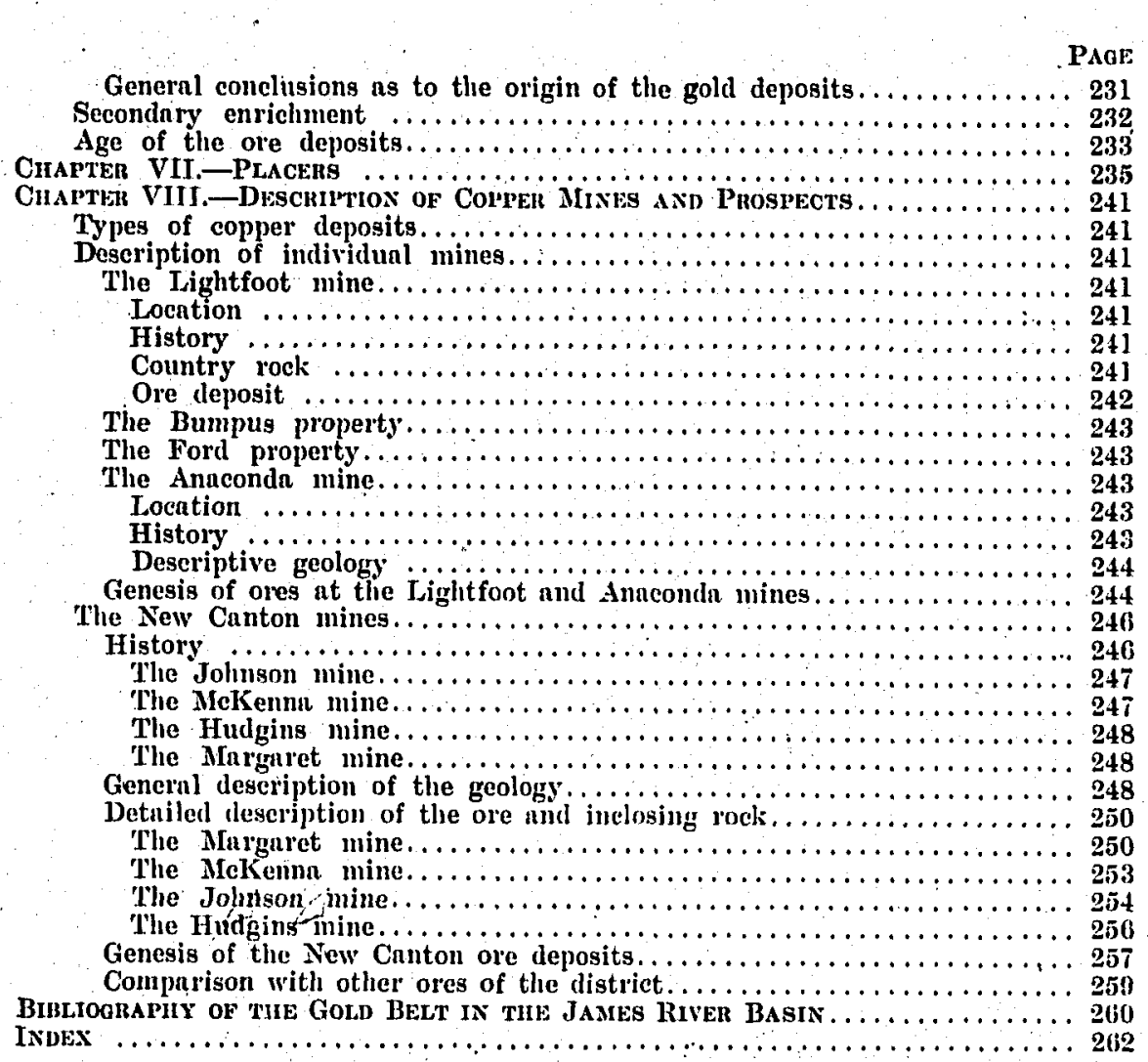




\section{ILLUSTRATIONS}

Plate

I. Topographic and geologic map of the gold belt in the James River

Facina Pagk Basin, Virginin $\ldots \ldots \ldots \ldots \ldots \ldots \ldots \ldots \ldots \ldots \ldots \ldots$ in pocket

II. Detniled geologic map of the gold belt on the north sicle of James River in Goochland and Fluvanna counties, Virginia.... in pocket

III. Fig. 1. Looking up James River from Bremo bridge. Rapids due to

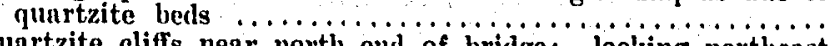

Fig. 2. Quartzite cliffs near north end of bridge; looking northenst

Fig. 3. Nearer view of quartzite cliffs, north side of James. River at

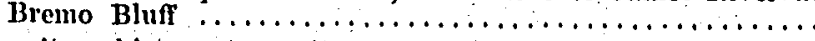

IV. Fig. 1. Cyanite schists outeropping near summit of Willis Mountain

Fig. 2. Cynnite schists outcropping on the Trent farm.............

V. Fig. 1. Photomicrograph of biotite-benring knotted schist, thin section

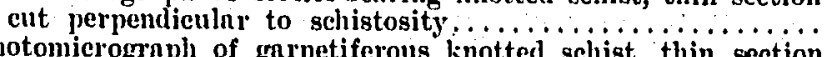

Fig. 2. Photomicrogrnph of gnrnetiferous linotted schist, thin section cut parallel to schistosity ........................

VI. Fig. 1. Ordovicinn sediments resting on eroded surface of mnssive

Fig. 2. Iooking nortl along summit of Willis Mountnin. Piedmont

VII. Fig. 1. Bed of tuff in Ordovician slates. Bluffs on soutl side of

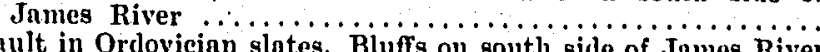

Fig. 2. Fault in Ordovician slates. Bluffs on south side of James River VIII. Fig. 1. Flow structure in bunded gneiss intruded between layers of

Fig. 2. Photomicrograph of plagioclase feldspar in vein quartz from

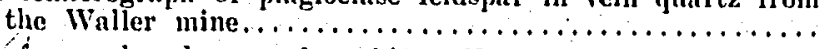

Ix. Mnp of aurface and underground workings, Young American mine.....

X. Fig. 1. Gyanite in vein quartz from Young American mine.........

Fig. 2. Jenses of vein quartz in gneiss, Young Americnn mine............

Figune

1. Index map showing location of area $\ldots \ldots \ldots \ldots \ldots \ldots \ldots \ldots \ldots$

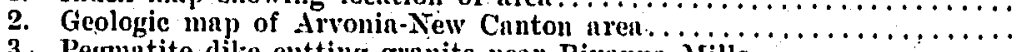

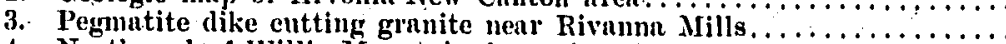

4. North end of Willis Mountain from the west. . . . . . . . . . . . . . .

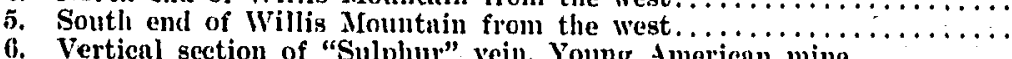

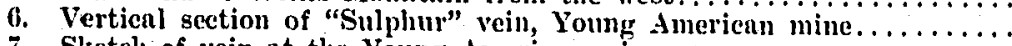

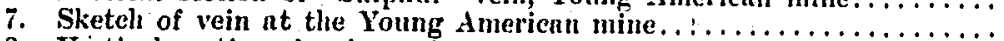

8. Vertical section showing vein quartz in a sheared zone, Young Aineri-

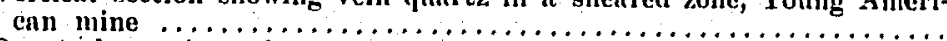

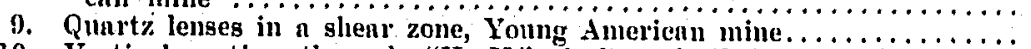

10. Vertical section through "H. V." shaft and "Sulphur" vein, Young

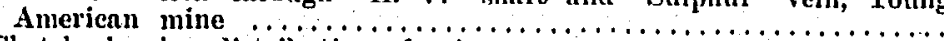

11. Sketch showing distribution of vein quartz, Young American mine....

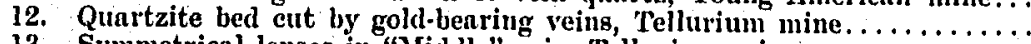

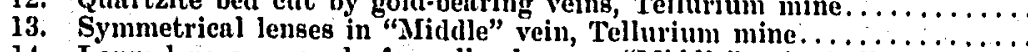

14. Iarge lens composed of smaller lenses. "Middle" vein, Telluium mine

15. Small fault cutting the "Middle" vein, Tellurium mine.............

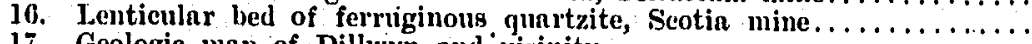

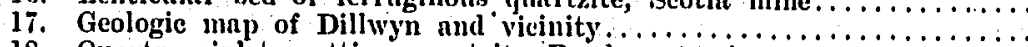

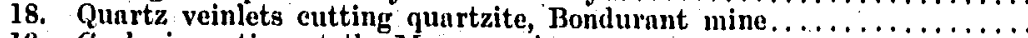

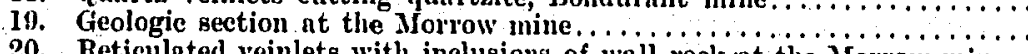

20. Reticulated veinlets with inclusions of wnll rock nt the $\mathrm{Mor}$. $\ldots \ldots \ldots$.

21. Sketeh showing recrystallization of quartz about garnets in schist...

22. Sketch showing radinl arrangement of quartz in garnetiferous schist. 


\title{
GEOLOGY OF THE GOLD BELT IN THE JAMES RIVER BASIN, VIRGINIA
}

\author{
BY STEPHEN TABER. \\ INTRODUCTION
}

This report is a geologic and economic investigation of the Gold Belt in the James River Basin, Virginia, an area comprising 700 square miles in Fluvanna, Goochland, Buckingham, Cumberland, Powhatan, and Amelia counties. The occurrence and origin of the gold, copper, and sulphide deposits within the area are discussed in detail. The commercial slates of the area, while of great economic importance, are only briefly mentioned in this report as they will be considered at length in Bulletin No. $X$, now in course of preparation by the Virginia Geological Survey.

The field studies which form the basis of this report were made by the writer during June, July, and August, 1910, and July and part of August, 1911.

No attempt has been made to evaluate individual mines or to determine whether they can be operated at a profit, as that is properly the work of the consulting mining engineer and geologist; but such basic problems as the origin and distribution of the ore deposits, and their probable variation in depth-problems which can not be solved by the examination of. a single property, or without the expenditure of much time and effort-have been investigated as fully as conditions would permit.

Acknowledgments.-The writer desires to thank $\mathrm{Dr}$. Thomas $\mathrm{L}$. Watson, State Geologist, under whose supervision the work was done, for the privilege of studying the area, and for his valuable advice and kindly assistance in the preparation of this report. He also wishes to acknowledge the many kindnesses shown him by the different operators in the district, and by others who aided him in the field investigations.

The topographic map of the gold belt in the James River basin (Pl. I) is compiled from the Palmyra, Farmville, Buckingham, and Appomattox sheets of the United States Geological Survey, with corrections inserted by the writer. The traverse maps; used as a base for the detailed geologic work, were compiled chiefly from surveys made by the writer. Control for the detailed map of the gold belt on the north side of James River (Pl. II) was furnished by the United States Geological Survey and the Chesapeake and Ohio Railroad, and for the Arvonia-New Canton map (Fig. 2) by the Chesapeake and Ohio Railroad. Other acknowledgments are made in the body of the report. 


\section{CHAPTER I. GEOGRAPHY AND HISTORY. LOCATION.}

The district described in this report is situated a little east of the geographic center of the State, and lies on botll sides of James River, about 60 miles above Richmond. It comprises the southeastern part of Fluvanna County, most of the western part of Goochland County, the northern three-fourths of Cumberland County, and adjacent portions of Buckingham, Powhatan, and Amelia counties, Virginia. The exact location is shown in the index map, fig. 1 , and a large topographic and geologic map of the area is given on Pl. I, which will be found in the pocket at the back of the book.

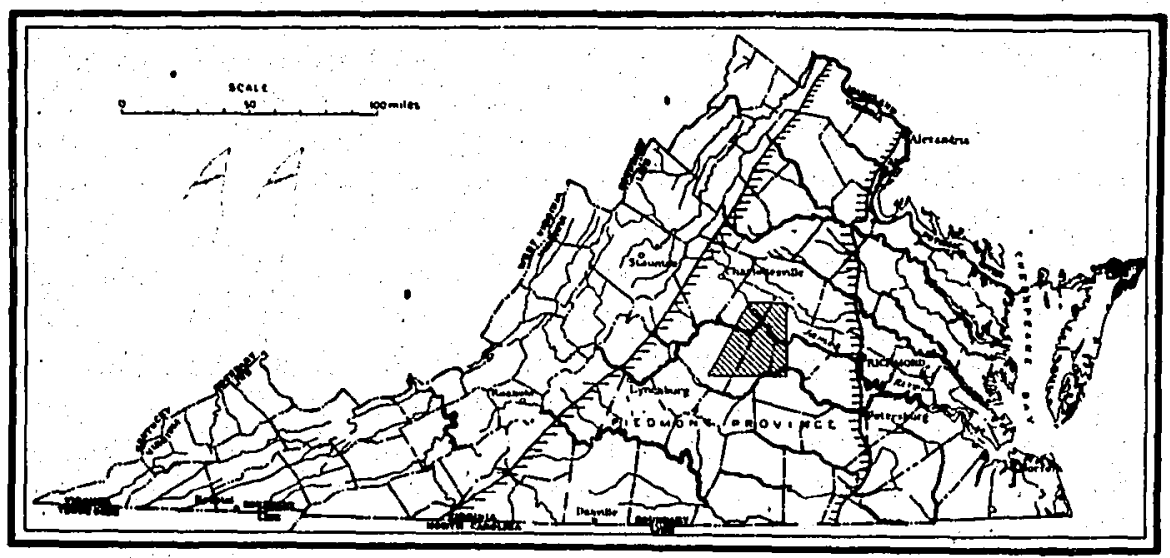

Fig. 1.-Index map showing location of area.

The area is trapezoidal in shape, being 30 miles long in a north and south direction, with a width of 15 miles at the northern end and over 32 miles along the southern boundary. It covers approximately 705 square miles,

The greater portion of the district is easily accessible from stations on the various railroads that cross it. The Chesapeake and Ohio Railway, following the north bank of James River, crosses the north central portion of the area in an east and west direction, while the Buckingham Branch of the Chesapeake and Ohio and the Virginia Air Line railways approxi- 
mately parallel the western boundary, the former extending south from Bremo Bluff to Rosney, its terminus near the southern line, and the latter lunning from Strathmore northenst to Carysbrook and thence northward approximately parallel with Rivanna River. The Tidewater and Western Railway, a narrow gauge line, crosses the sontheastern corner of the aren.

With reference to the major physiographic divisions of the State, the area is located in the center of the Piedmont Plateau; it lies within the belt of old crystalline rocks that extends from New Brunswick to Alabama; and is a part of the gold belt in the Southern Appalachians region.

\section{TOPOGRAPHY.}

The topographic features of the gold belt present little by way of variation; the land surface is gently rolling, consisting of broad flattopped hills or ridges and narrow valleys. The ridges are remarkably uniform in elevation, ranging from 450 feet above sea level along the eastern border of the area, to 550 or 600 feet in the western portion, and the valleys of the larger streams have an avernge elevation of about 225 feet.

The only variation in the monotony of the topography is furnished by Willis Mountain in the southwest corner of the area, which is the most prominent single feature of relief found in the State east of the outlying ranges of the Blue Ridge. It consists of a narrow ridge, about two miles long in a north and south direction; which rises abruptly from the Piedmont Plateau to a height of 1,159 feet above sea level, the upper portion being exceedingly precipitous and almost bare of vegetation.

\section{DRAINAGE.}

The area is drained by James River and its tributaries. James River flows directly across the area in a general ensterly direction. Rivanna River and Byrd Creek are the principal streams entering James River on the north; and Slate River, Willis River, and Muddy Creek on the south. Appomattox River, flowing northeasterly, cuts across the southeast corner of the area and finally empties into the James below Richmond. Minor creeks and branches spread out from the principal streams, and completely drain all parts of the district.

The estimated mean yearly discharge of James River at Cartersville, where the drainage aren is 6,232 square miles, is 8,189 cubic feet per second. These figures are based on daily observations taken between January 1, 1899, and December 30, 1905, under the direction of the Hydrographic Branch of the United States Geological Survey. During

aGrover, N. C., and Bolster, R. H., Hydrogripliy of Virginia, Bull. No. III, Geol. Survey of Virginia, 1906, pp. 142-152. 
GEOLOGY OF THE GOLD BELT IN THE JAMES RIVER BASIN.

this period of seven years the maximum discharge for any single day was 97,800 cubic feet per second on December 15, 1901, and the minimum discharge for any single day 842 , cubic feet per second on September 15 , 1900.

soIr.

The alluvial soils of the valleys, while limited in extent, are very rich; but the residual soils that cover the ridges are for the most part lean, and do not make first-class farming land. It was originally covered with a heavy growth of timber which has been greatly thinned out by cutting. All of the bottom lands and much of the uplands are at present under cultivation, but large areas of the latter have been allowed to grow up with a second growth of timber. While not naturally so rich as the bottom lands, much of this residual soil is capable, under proper farming methods, of a high degree of productivity.

\section{CLIMATE.}

The climate is equable and agreeable during the greater part of the year; the mean annual temperature is about $56^{\circ} \mathrm{F}$, and the thermometer seldom drops as low aw zero in the winter or reaches as high as $100^{\circ}$ in the summer. The average yearly precipitation is about 42 inches, and this is quite evenly distributed throughout the year, so that prolonged droughts in summer or excessive rain and snow in winter are seldom experienced.

\section{CULTURE.}

The country is sparsely populated, and there are no large towns within the area. The chief industry of the inhabitants is farming, with corn and tobacco as the principal crops. Considerable lumbering is still carried on, and many railroad ties are shipped out of the district. Slate has been extensively quarried in Buckingham County for many years, and mining was at one time an important industry, but recently it has been carried on only in a spasmodic way. There are practically no manufacturing industries in this section, and although there is good waterpower in certain localities it has as yet received little attention. Many of the smaller streams have been utilized to run saw mills and grist mills for local custom, but this is the extent of water-power development. Within the past few years great strides have been made in the public school system, and large new school buildings have been erected in nearly all of the towns. 


\section{HISTORY.}

The early history of gold mining in the James River valley is so closely connected with the development of that industry elsewhere in Virginia, and indeed throughout the Southern Appalachians region, that a brief outline of the more important happenings in other parts of the gold belt will be given. The general history of the entire gold belt was summed up by J. D. Whitney in 1854, and by Geo. F. Becker ${ }^{b}$ in 1895.

According to Becker the first mention of gold in the Southern Appalachians states is by Herrera ${ }^{\circ}$, and "is to the effect that on June 4, 1513, while Ponce de Leon lay near the southern end of the peninsula of Florida, he was informed that a cacique in the neighborhood had a quantity of gold." Several years later Spanish and French explorers refer to the possession of gold by the Indians; and Lemoyne, in his "Brevis Narratio" method used by the Indians in separating gold from sands, which they fourd in rivers flowing from the Appalachian Mountains. Authorities differ as to how the Indians obtained their gold, but it seems probable that no systematic efforts were made by them to recover the metal. It can scarcely be doubted, however, that they found gold nuggets and made use of them, for in later years white miners found many large nuggets on the surface, some weighing several pounds, and such lumps must lave been more plentiful before the country was settled. While the Spaniards are reported to have done some mining in Georgia in the seventeenth century, practically no systematic work was undertaken until after the beginning of the nineteenth century.

The earliest authentic reference to gold in Virginia is by Thomas Jefferson in 1782. He describes a lump of ore found on the north side of Rappahannock River about 4 miles below the falls. The gold "was interspersed in small specks through a lump of ore of about four pounds weight, which yielded seventeen pennyweight of gold of extraordinary ductility."e

In 1799, the Reed nugget was discovered in Cabarrus County, North Carolina, and some years later more lumps were found, one weighing 28

aThe Metallic Wealth of the United States, Philadelphia, 1854, pp. 114-134.

U. S. Geol. Survey, 1805 , Gold Belt of the Southern Appalachians, 18th Ann. Rept. oHerrera Dec. 1, Book IX, Chap. 5 .

dPublished by De Bry in 1501. eJefierson, Thomas, Notes on the State of Virginia, $2 \mathrm{~d}$ Am. ed., Philadelphia;
Nov..12, 1794, $\mathrm{p}, 32$. 
pounds. Up to 1825 all the gold produced in North Carolina came from placer gravels, but during that yenr veins were opened in Montgomery County and afterwards in Mecklenburg County. Between the years 1804 and 1828, all gold of domestic proluction deposited at the United States mint, amounting to only $\$ 116,000$, came from North Carolina; but in 1829 the mint records show a production of $\$ 2,500$ from Virginia, and during the same year South Carolina sent gold worth $\$ 3,500$ to the mint.

In Virginia gold was discovered at very nenrly the same time in both Orange and Goochland counties. Dr. Watson states that, "the Virginia Mining Company of New York, operating between the years 1831 and 1834, the Grasty tract of land in Orange County, was the first gold mining company incorporated in Virginia. The date of the incorporation was March 10, 1832. The Orange County, Virginia, deed books show that a one-lyalf interest in a 20 -year lease on the 5 -acre mining tract, dated 1829 , was purchased in 1831 for $\$ 30,000$ in cash." "a

The first discovery of gold in the James River basin was probably on the Collins place in Goochland County, about 1829. The first attempt at mining was by the Fishers, who built dams across the branch and prepared to work the gravels in rockers. Before active mining had actually begun, the property was turned over to Stevens Collins, who continued to work, the placers for several years, and the Fishers transferred their operations to Busby Branch, 1.5 miles southwest of Talsscott. The discovery of the gold-bearing veins at the Tellurium mine is said to have been made in 1832 by G. W. Fisher while hunting, and according to J. R. Hamilton, veins were found on the Waller property by John Moss during the same year. Discoveries on other properties in the district followed in rapid succession. When Prof. W. B. Rogers wrote his "Report of the Geological Reconnoissance of the State of Virginia, 1835," Booker's mine (the Morrow mine) was already under active development. The history of the different mines, so far as known, is given under the description of individual properties in Chapter V.

On most properties gold was found first in the branches, and as the placer gravels were frequently rich and could be worked by crude methods necessitating Jittle or no capital, the deposits along the branches were rapidly exhausted. In most cases the mining was done by lessees, who paid a royalty of about 10 per cent. of the gold recovered. The first primitive washing was with the pan, but almost from the first rockers were used on the branch gravels. Long-toms were also used; and in a few

aWatson, Thomias I., Mineral Resources of Virginia, Lynchburg, 1907, p. 549. 
places lydraulic mining was carried on, but most of the branches had insufficient grade to permit the use of sluice-boxes.

The veins from which the placer gold was derived were frequently discovered in working up the branches, and as the placer gravels became exhausted, a close search was made for the primary deposits. When the veins were first found, many of them were worked in a very primitive fashion, the gold being recovered by the crudest mechanical processes. The high percentage of free gold, the grent depth of residual decay, and the low cost of mining these ores, helped to make such methods profitable. Small shafts or pits were sunk on the outcrops where pannings of the surface soil indicated the presence of much gold. In the decomposed rock above water level blasting was not necessary, and in some places it was possible to sink nenrly 100 feet through "picking ground." The ore was usually raised by hand or sometimes with a horse-whim.

At first the ore was crushed by hand in iron mortars after a preliminary hand sorting, and the gold obtained by pauning, mercury being sometimes used to amalgamate the gold. Crushing was also carried on in wooden mortars lined with iron, while the heary pestles were attached to long sweeps operated by hand. At the Tellurium mine an arrastra driven by horse-power is said to have been employed for a short time, but was soon replaced by a stamp mill, or "pounding mill" as they were then called. According to Nitze and Willins this stamp mill was in operation as early as 1836, making it one of the first, if not the first, to be erected in this country. It had six wooden stimps, shod with iron, which weighed about 50 pounds each, and the ore was crushed on an iron die plate. The stamp stems were square and did not revolve as in later mills, for the cams worked in slots cut into the stems.

At a later clate larger and more efficient mills were installed, a 40stamp mill being built by Commodore Stockton at the Tellurium mine as early as 1848 , while a mill with 72 stamps was in operation at the Morrow mine, Buckingham County, in 1854. Tremain steam stamps, various : types of rotary pulverizers, and a number of other mills have been tried with more or less success at different mines.

As the water level was reached the rock became harder, rendering blasting necessary, the water that was encountered had to be removed by pumping, and the sulphides, which began to replace the oxidized ores found at the surface, contained less free gold. It is also probable that the total gold content of the surface ores was higher than that of the sulphide ores, because of some enrichment through concentration of a part of the 
gold originally present in the eroded portions of the veins. All of these factors combined to make mining more expensive and the recovery of the gold more difficult, forcing most of the mines to cease operation after the ores above water level had been exhausted. This period in the development of many of the mines was approximately coincident with the outbreak of the Civil War, which put a stop to practically all mining operations both in Virginia and in the South generally.

Since the close of the war there have been spasmodic attempts to reopen many of the mines, and while these efforts have been accompanied by varying degrees of success and failure, they lave for various reasons always ended in the same way-the final cessation of all mining. Gold can be recovered from refractory sulphide ores, but the methods of extraction are more complex and costly than the simple amalgamation processes that suffice for the oxidized ores near the surface. In the case of a producing mine, the introduction of auxiliary processes for the treatment of refractory ores necessitates an additional outlay of capital; but the metallurgical process now used had not been perfected when the exhaustion of free milling ores made the profitable handling of sulphide ores a necessity, if the mines were to remain open. It is much more costly to introduce new processes at old mines that have been long abandoned, for with the ores near the surface exhausted, prospecting is more difficult, and a larger amount of dead work must be carried out before pay. ore can be developed. Most companies that have undertaken to reopen Virginia gold. mines have done so with insufficient capital, and usually the men in charge of operations have lacked technical training. Mismanagement and ignorance of the common principles of mining have resulted in the erection of expensive surface plants before the mines were developed to a point that would permit the making of adequate tests of the quality and probable quantity of the ore.

The metallurgical processes which have elsewhere proved successful in recovering gold values from refractory ores, have usually included concentration of the sulphides, and separate treatment of the concentrates and tailings. The concentrates are generally smelted with other ores, or treated by chlorination or cyanidation after a preliminary roasting, while the tailings are usually subjected to some variation of the cyanide process. In 1879, a Mears chlorination plant was erected at the Phoenix mine in North Carolina, under the management of Mr. A. Thies, who improved and developed it into what was later known as the Thies process. In 1881, the Mears process is reported to have been tried at the Snead mine; but no details are given. An attempt to treat the sulphides at the Morrow mine by the Mears chlorination process, in 1893-94, is said to have failed 
because of mechanical defects in the process used, though $n$ satisfactory extraction of the gold was obtained.

According to Nitze and Wilkins a cyanide plant was in operation at the Gilmer (Young American) mine in 1893 ; with what success is not known. A preliminary test of the cyanide process, at the Bertha and Edith mine in $189 \%$, is reported to hnve been successful, but the plant was destroyed by fire soon after completion and was not rebuilt. At the Hughes mine both concentrates and tailings were treated by the cyanide process, the sulphides being first roasted in a muffle furnace, and an extraction of over 90 per cent. is claimed.

Recently there has been renewed activity in the district, a number of the old mines have been reopened, and some new development work done, but as yet none of the mines have gone much deeper than 100 feet below the surface. As the free milling ores above water level are now practically exhausted, future mining necessarily depends on the successful treatment of sulphide ores.

\section{PRODUCTION.}

The statistics of production during the years when gold mining was most active in Virginia, are not sufficiently detailed to make possible the compilation of data giving the production of individual mines, or of the district as a whole. The few figures that are available relate to particular mines, and are giren under the descriptions of the different properties in Chapter V. The annual production of gold in the James River basin has probably varied with that of the State. After the first deposit of $\$ 2,500$ at the United States mint in 1829, the gold production of Virginia steadily increased until 1833, when it reached a value of $\$ 104,000$. Thereafter it averaged about $\$ 56,000$ yearly up to the outbreak of the Civil War, and since the war the production has ranged from a minimum of $\$ 2,024$ in 1884 , to a maximum of $\$ 15,000$ in 1906 , averaging about $\$ 6,000$.

\section{PREVIOUS GEOIOGIC WORK.}

No detailed geological work dealing with this or any other portion of the gold belt in Virginia has been published previous to this report. Since the first discovery of gold, the mines in the James River basin have been examined from time to time by geologists and mining engineer's, and a number of reports. on individual properties have been published. Some of the early American and English geologists, who visited the district, became interested in the genesis of the ore-bodies and advanced theories to explain their mode of formation; but at that time the petrographic microscope had not been developed, and the science of geology had not reached a stage permitting detailed geological study in an area of old 
metamorphic rocks. In more recent years the lack of accurate topographic maps, the depth of residual decay, and the absence of deep mines, linve combined to discourage geologists from undertaking work in the district.

Several studics treating of the gold belt in the Southern Appalachians region as a whole have bcen published, and in these the principal mines in the James River valley receive brief mention. A number of papers, usually brief in character and dealing chiefly with the economic and engineering phases of the properties, have appenred from time to time. In the Bibliography is given a list of the titles of all the principal papers which refer in any way to the gold veins in this district. A brief review of the more important conclusions developed by the different geologists that have worked in the area is outlined below.

The first geological work, of which there is any record, whs done by Prof. Wm. B. Rogers, who in 1835 published his "Report of the Geological Reconnoissance of the State of Virginin." He mapped all of the rocks in the gold belt as primary, but states that the rocks lying to the west of the belt of gneiss "nssume various intermediate characters, until at length the truly crystalline structure is lost, and numerous forms of slate of very peculiar and equivocal features make their appearance. At what precise points the rocks of unequivocally primary character terminate, future researches must ascertain."

In describing the veins, Rogers points out that while in the main they conform to the inclination of the enclosing strata, this correspondence is far from exact, and that in places the veins divide, and the separated portions reunite or send off other branches. From this he concludes:

"It would thus appear, that these numerous reins of quartz are not to be regarded as deposits coeval with the regularly stratified rocks among which they are found, since in that case their position and structure would exhibit a like degree of uniformity, but as 'matter which, subsequent to the production of the neighboring rocks, was forcibly injected between them by igneous agencies from beneath, rising in the directions of least resistance, and therefore, generally, though by no means uniformly, following the plains of stratification of the rocks through which they passed. Instead, therefore, of considering them as beds like the adjoining strata, as some writers have done, we would incline to class them among veins of injection, of which numerous instances occur in other parts of the globe. We are the more persuaded of the correctness of this view of their origin, from the consideration that throughout all the region in which the quartz veins are found, very peculiar modifications in the structure and composition of the surrounding rocks are invariably to be observed-modifications for which no adequate cause can be found in the other igneous rocks which occasionally occur."

\footnotetext{
p. 72.

a.Rogers, Wm. B., A Reprint of the Geology of the Virginias, New York, 1884,
72.

tIbid., pp. 75-77.
} 
Prof. B. Silliman examined the Busby and Moss mines in 1836, and while in the district also visited the 'lellurium mine. As a result of his observations be reached conclusions. in regard to the nature of the veins which are at variance to those advanced by Prof. Rogers. He states that: "The auriferous or gold-benring quartz of the gold region of Virginia (and, as far as I am informed, of the states farther south) forms, not strictly veins but rather beds or layers-in general not interfering with but conforming to the regular structure of the country."

Prof. Rogers, in his "Report of the Progress of the Geological Survey of the State of Virginia for the Yenr 1839," describes the Triassic area lying in Prince Edward, Cumberland, and Buckingham counties under the name of "middle secondary formations," but maps the rest of the area embraced in the present report as "primary."

Prof. D. T. Ansted in 1854, after a careful study of the region, strongly opposed the theories of Rogers, both as to the genesis of the gold veins and in regard to the manner in which the Alleghanies were formed. Ansted points out the resemblance of many of the "so-called veins" to the quartzite exposed in the bluffs at New Canton and says: "It is not without importance that these hard sandstone bands pass into and alternate with quartz bands parallel to them, and that this quartz is hyaline, and has in all respects the aspect and general character of the auriferous veins of the adjacent Uistricts." He further states that:

"There were perhaps originally a multitude of beds, consisting of such materials as are still accumulating every day upon the earth. These beds were altered more or less by chemical agency, but while some still retain clear marks of their mechanical origin, others have become so far crystalline that the new arrangement of particles obliterated the old. That the syenites, greenstones, and gneissic rocks, as well as the chloritic schists, hornblendic schists, pale and blue slates, and other well-marked mechanical rocks, were once alternating aqueous deposits, there is no doubt in my mind; and $I$ also believe that the gold as well as the iron was originally disseminated through the whole, and has been since rearranged and collected into certain portions, whether veins or bands, by a process of segregation, which has also changed siliceous sands into the condition of alternating quartz bands."

"Silliman, B., Remarks on Some of the Gold Mines, and on Parts of the Gold Region of Virginia, Founded on Personal Observations Mnde in the Months of August and September, 1836, Amei. Jour. Sci. and Arts, 1837, vol. xxxii, pp. 08-130.
lIbid., pp. 322-323.

oAnsted, D. 'I', 'The Alleghnnies and the Gold District of Enstern Virginin, Scenery, Science and Art, London, 1854, Chap. 3, p. 287.

IAnsted, D. 'I., Op. cit., p. 202. 
Ansted described the Waller, London and Virginin, and Morrow veins, all of which were exposed at the time of his visit, and his descriptions show that he was a remarkably careful and accurate observer.

Dr. H. Credner, during the latter part of 1865 , made a detailed examination of the gold deposits of Virginia and North Carolina, and the portion of his report relating to Virginia 'mines, which was published in 1868-69, gives a comprehensive list of the gold-bearing properties in the Jaines River basin. His conclusions in regard to the geology of the deposits are stated as follows:

"The slate belt is of the highest technical interest, on account of the rariety and multitude of mineral deposits which it encloses. Mineralogically it is made up of soft micaceous slates, siliceous slates poor in mica, chloritic, talcose, and roofing slates. All these varieties have an immediate connection with the analogous slate formation of North Carolina, which has been named by. Emmons the Taconic system. We are therefore justified in describing this Virginia slate zone as belonging to this preSilurian oldest fossiliferous system.

"Somewliat as the coal measures lie between carboniferous sandstones so between the layers of these slates lie parallel metalliferous intercalations, striking and dipping with the enclosing rocks and therefore not veins proper in a geological sense." a.

In 1885, I.C. Russell made a reconnoissance of the Triassic (Newark) area lying in Prince Edward, Cumberland, and Buckingham counties, determining the presence of a fault along its eastern boundary north of Farmville, and several north and south faults in the central portion of the area. $b$

In 1892, N. H. Darton announced the discovery of fossils in the slate of the Arvonia quarries, and the identification of these fossils by Walcott placed the slates in the upper Ordovician (Cincinnatian).$^{c}$

In 1911, Thomas L. Watson and S. L. Powell correlated the Arvonia slate belt with the Quantico slate belt in Prince William, Stafford, and Spottsylvania counties, Virginia, and described the occurrence of tuffaceous beds and metamorphosed rhyolite interbedded with the slates in each district. ${ }^{l}$

aCredner, H., Report of Explorations on the Gold Fields of Virginia and North Carolina, Amer. Jour. of Mining, 1868, vol. vi, p. 361.

pp. 88-89. oDarton, N. H., Fossils in the "Archenn" Rocks of Central Piedmont, Virginia.
Amer. Jour. Sci., 1802, vol. xliv, pp. 50.52.

dWatson, Thomas L., and Powell, S. I., Fossil Evidence of the Age of the Virginia Piedmont Slates, Amer. Jour. Sci., 1911, vol. xxxi, pp. 33-44. 


\section{CHAPTER II. \\ DESCRIPTIVE GEOLOGY AND PETROGRAPHY.}

\section{INTRODUCTION.}

The results of the areal survey of the gold belt in the James River basin are shown on the geological maps, Pls. I and II, and figs. 2 and 17. Owing to the lack of sufficient exposures it is not possible to map all of the region in equal detail. Plate $I$ is a topographic and geologic map of the entire area, on which only the principal formations are differentiated. The northwestern portion is occupied chiefly by pre-Cambrian schists, quartzites, and gneisses of sedimentary origin, and the southeastern portion, by more or less gnejssic igneous rocks of the granite-diorite family. The northern end of the Farmville aren of Triassic rocks crosses the southern boundary and occupies a small area between Ca Ira and Willis Mountain.

A narrow belt of Ordovician rocks extends in a southwesterly direction from a point on Long Island Creek, between Palmyra and Wilmington, nearly to Alpkía in-Buckingham County, a distance of about 22 miles. Its boundaries are shown on the smaller detailed maps bit not on Pl. I. A large scale map of the entire slate belt will be published shortly in connection with a report on the slate deposits of Virginia, now in preparation by the State Geological Survey.

Most of the gold mines are situated in the northeastern portion of the district shown on Pl. I, and this section is given in greater detail on Pl. II. Figure 2 is a detailed geological map of the region around New Canton and Arvonia, Buckingham County, showing the distribution of the Ordovician rocks, and the relation of the New Canton copper mines to the contact between the pre-Cambrian schists and intrusive granite,

All of the rocks in the area mapped, except the Triassic sediments, have been extensively altered by regional dynamic metamorphism, the degree of alteration being most intense in the pre-Cambrian rocks. In the following detailed descriptions the rocks are divided into two classes, namely, those that are sedimentary in origin and those that are igneous in origin; and the subdivisions of the two classes are based, so far as possible, on relative age. 


\section{ROCKS SEDIMENTARY IN ORIGIN.}

GENERAI CLABSIFICATION.

The rocks of sedimentary origin, described in this report, may be divided for purposes of mapping and description into three main groupspre-Cambrian, Ordovician, and Triassic-which are separated from one another by great unconformities. These groups will be discussed in the order given, which is that of relative age.

The pre-Cambrian rocks are the oldest in the district and have been extensively altered by dynamic regional metamorphism and by the intrusion of large masses of igneous rocks. In many instances they have been so completely metamorphosed that it is difficult or impossible to discover the charncter of the original sediments. For the most part these rocks have a fairly uniform strike in a northeast and southwest direction, and dip toward the east at angles varying from 45 to 90 degrees.

The Ordovician sediments are next in age to the pre-Cambrian rocks, but are separated from them by a long time interval, and are much less metamorphosed. The beds of this formation have been extensively folded and faulted, and while they mostly dip at steep angles, there is not the same uniformity in this respect as in the older sediments; the dip of the Ordovician beds changes suddenly within short distances, while the preCambrian rocks are nearly isoclinal in dip.

The Triassic sediments constitute the youngest formation of the area, unless the recent alluvium, deposited in the larger valleys, is taken into consideration. The Triassic rocks have not been subjected to the crustal movements which have metamorphosed the older rocks, and since they have never been deeply buried, they are only partly consolidated. The beds dip gently in various directions and have been only slightly disturbed by minor faulting.

\section{PRE-CAKBRIAN.}

General Statement.

In the absence of direct fossil evidence, the correlation of the rocks which have been mapped as pre-Cambrian must rest entirely on lithologic and structural grounds. It is known that the Proterozoic era in North America was brought to a close by great crustal movements, and wherever the rocks belonging to this period have been observed in the Piedmont region, they show the effects of intense dynamic metamorphism. The chief evidence of the pre-Cambrian age of the older rocks, in the area under consideration, is furnished by their relatively high degree of crystallinity 
and extremely schistose structure as compared with the rocks a short distance to the west, which are believed to be Cambrian in age. (See Geological Map of Virginia.")

The grent age of these rocks is also evidenced by the long period of time intervening between their formation and the deposition of the Arronia slates, upper Ordovician (Cincinnation) in age, which are the oldest rocks in the area known to be fossil-bearing. After the pre-Cambrian sediments were laid down, they underwent the profound changes which resulted in their metamorphism; they were intruded by great masses of igneous rocks; and finally, sufficient time elapsed for erosion to remove a large amount of overlying material, and expose the intrusive granite and other rocks of the anamorphic zone; and all of this lappened prior to the deposition of the Ordovician sediments.

The subdivisions of the pre-Cambrian series in this district must be based, in the absence of fossils, entirely on lithologic grounds. It is not even possible to state definitely which beds were laid down first or which were laid down last. The rocks have all been extensively altered by regional metamorphism and are entirely crystalline, so that it is frequently difficult to determine their original character; and in some instances, especially in the vicinity of later intrusives, it is impossible to distinguish between those that are igneous and-those that are sedimentary in origin. The principal rock types are quartzites, schists, and gneisses, varying in texture and mineral composition; and rocks occur that are intermediate between the more important varieties. In fact nearly all gradations exist between the different extremes in mineral composition.

\section{Quartzite.}

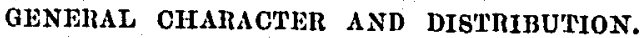

Quartzites are fine-grained, siliceous rocks, originally deposited as beds of sand and later firmly cemented through metamorphic agencies. Some of the pre-Cambrian quartzites in this area are very pure, consisting almost exclusively of quartz; but usually there is more or less mica and chlorite present in small flakes, and with increase of these minerals the rocks grade into mica schists. In places the quartzites are highly ferruginous, containing considerable percentages of hematite and magnetite, and at several localities the iron content is so high that the beds have been prospected for 1011 .

aWatson, Thomas L., Geological Map of Virginia, Virginia Geological Survey; 
iron ore. The qunrtzites also contain variable but usually unimportant amounts of feldspar, small inclusions of zircon, ilmenite, and rutile needles; and near igneous contacts, such minerals as garnet, hornblende, sillimanite, and cyanite are occasionally present in the impure varieties.

Since they are strongly resistant to erosion, the quartzites commonly outcrop along the ridges, and in places where the larger streams cut through such ridges the valleys are narrower, being frequently enclosed by cliff-like bluffs, while rapids are present in the channels. The residual soils resulting from the disintegration of the quartzites are sandy and infertile.

- Most of the quartzite beds are less than 20 feet in thickness but some of them measure over 200 feet. They are frequently lenticular in shape, pinching out along the strike and dip, though some of the more persistent beds can be traced for a distance of several miles. The quartzites are the most widely distributed of all the rocks in the pre-Cambrian series of altered sedimentaries, yet, owing to the high inclination of these beds they do not form extensive areal formations.

The beds of quartzite are commonly mistaken for quartz veins and much money has been wasted in sinking pits to prospect them for gold.

$$
\because \text { DETAILS OF OCCURRENCES. }
$$

Bremo Bluff.-The most prominent exposures of quartzite occur on either side of James River just above the railroad station at Bremo Bluff. Here within a distance of half a mile there are a number of beds, ranging up to 200 feet and over in thickness, which are interbedded with finegrained schists, the strike of the formations being about $\mathrm{N} .20^{\circ} \mathrm{E}$., and the dip $80^{\circ}$ to $90^{\circ}$ east. The largest beds of quartzite outcrop near the Bremo bridge over James River, and in passing westward they become successively thinner and more impure until they entirely disappear.

Because of their great resistance to erosion the larger beds of quartzite form a ridge, having an elevation of about 150 feet above the floor of the valley; and where this ridge is cut through by the river, it terminates in abrupt cliffs (see Pl. III, figs. 2 and 3), and the valley is much narrower than it is a short distance above and below (see map, fig. 2). The ledges of quartzite outcrop in the bed of the river, causing the rapids shown in Pl. III, figs. 1 and 2. The piers supporting Bremo bridge are built on one of these outcrops. 

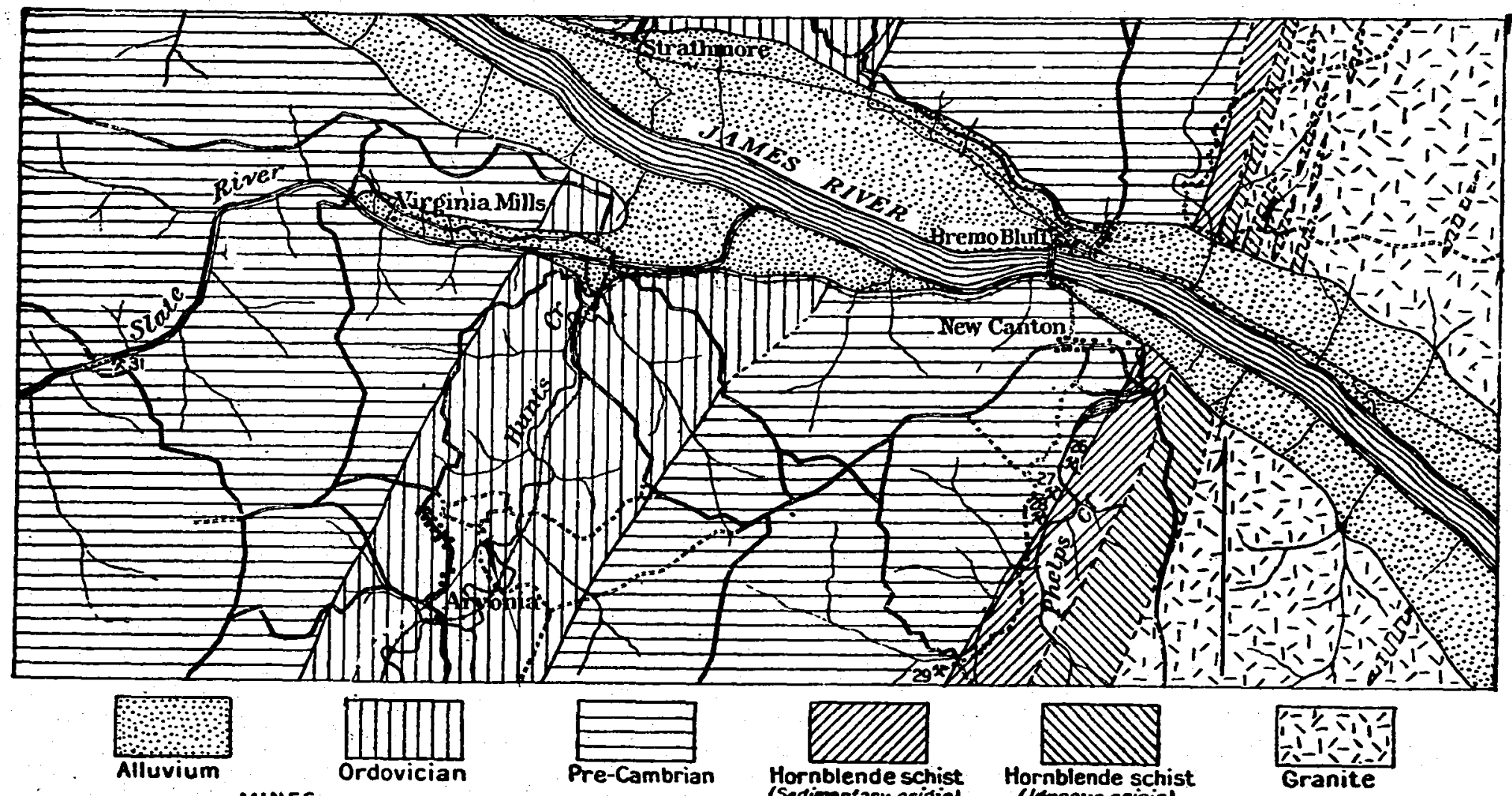

26. Margaret MINES 27. McKenna 29. Mudgins 31. Lightfoot
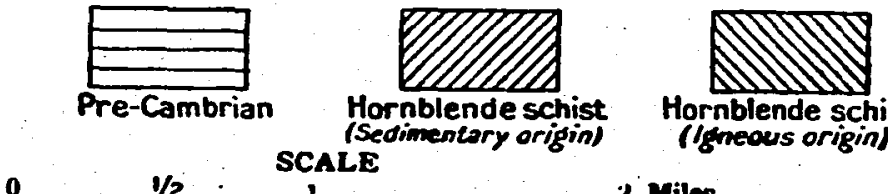

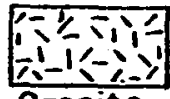

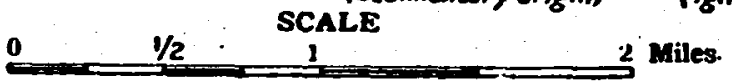

Fig. 2.-Geologic map of Arvonia-New Canton Area 
The quartzite is a fine-grained, close-textured rock, light gray in color when fresli, turning to light brown upon weathering, and where purest is nearly massive. The crustal movements, which have intensely metamorphosed the softer rocks with which they are interbedded, have scarcely affected the quartzites. Close inspection, however, shows a slight schistosity parallel to the bedding, and this becomes more conspicuous where the rocks are less pure. Fine flakes of sericite, chlorite, and biotite, and more rarely a little magnetite, pyrite, and garnet are the principal mineral impurities that may be detected megascopically.

In places the quartzites contain numerous small angular cavities arranged in bands or zones parallel to the bedding, and some of these are filled with calcite. The shape and distribution of these holes suggests that they may be due to fossils, possibly brachiopods, but if so they are so badly distorted as to make identification impossible. Quartz veinlets, averaging less than an inch in thickness, occasionally cut the quartzite, and some of the veinlets contain calcite.

Examined in thin sections under the microscope, the quartzite (Spec. $452)^{a}$ consists chiefly of small grains of quartz, nearly uniform in size, which fit closely together as in a mosaic. Dust-like inciusions are plentiful, especially near the border portions of the grains. The quartzite has evidently úudergone considerable recrystallization, with possibly some enlargement of the original grains by the addition of quartz in parallel orientation; and the border inclusions probably represent iron oxide and other interstitial-material which has become incorporated in the enlarged grains. Garnet occurs in small, irregular grains which are much fractured and partly altered to chlorite. Numerous small flakes of sericite are present, probably derived chiefly from argillaceous material, and there is also a little plagioclase and orthoclase feldspar, some of which shows partial alteration to sericite. Chlorite occurs in small, dark green flakes, and other minor accessories are biotite, light brown to green in color, a few small grains of magnetite and pyrite, and minute, colorless inclusions of zircon. The quartz shows very little optical distortion, possibly because of the extensive recrystallization.

Tellurium mine.-The so-called "Big Sandstone" vein, at the Tellurium mine, is a bed of quartzite cut by gold-bearing veinlets and slightly mineralized by the vein-forming solutions. This bed of quartzite varies up to 6 feet or more in thickness and can be traced for a distance of 3

a'The numbers plnced in parenthesis refer to field specimens and microscopic thin-sections, which are on file at the office of the Virginin Geological Survey. 


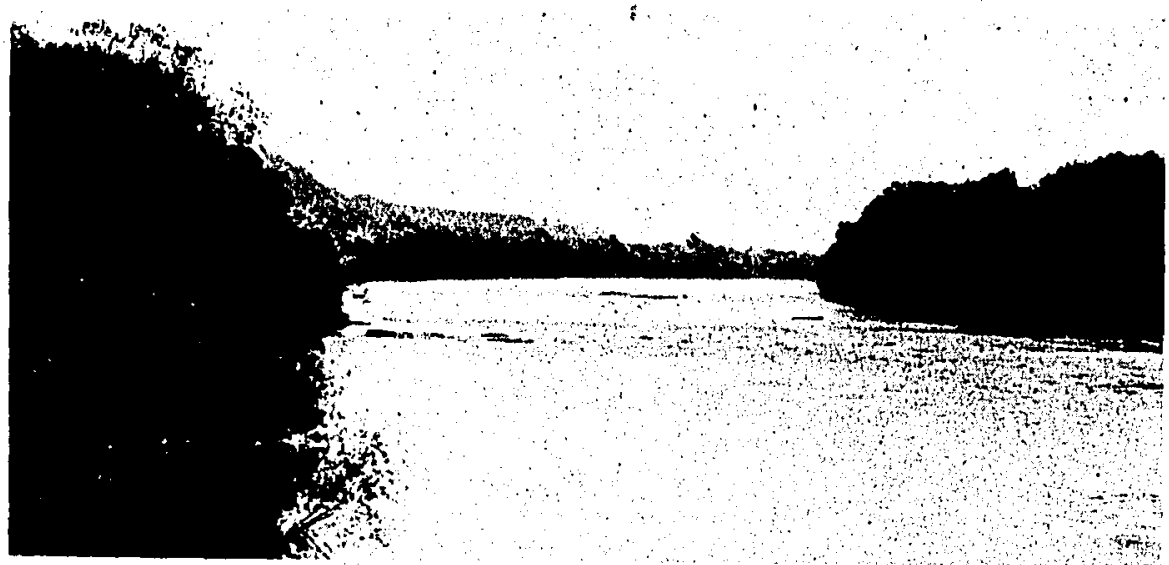

Fig. 1.-Tooking "1 dames River from Bremo brilge. Rapids due to qunrtyite beds.

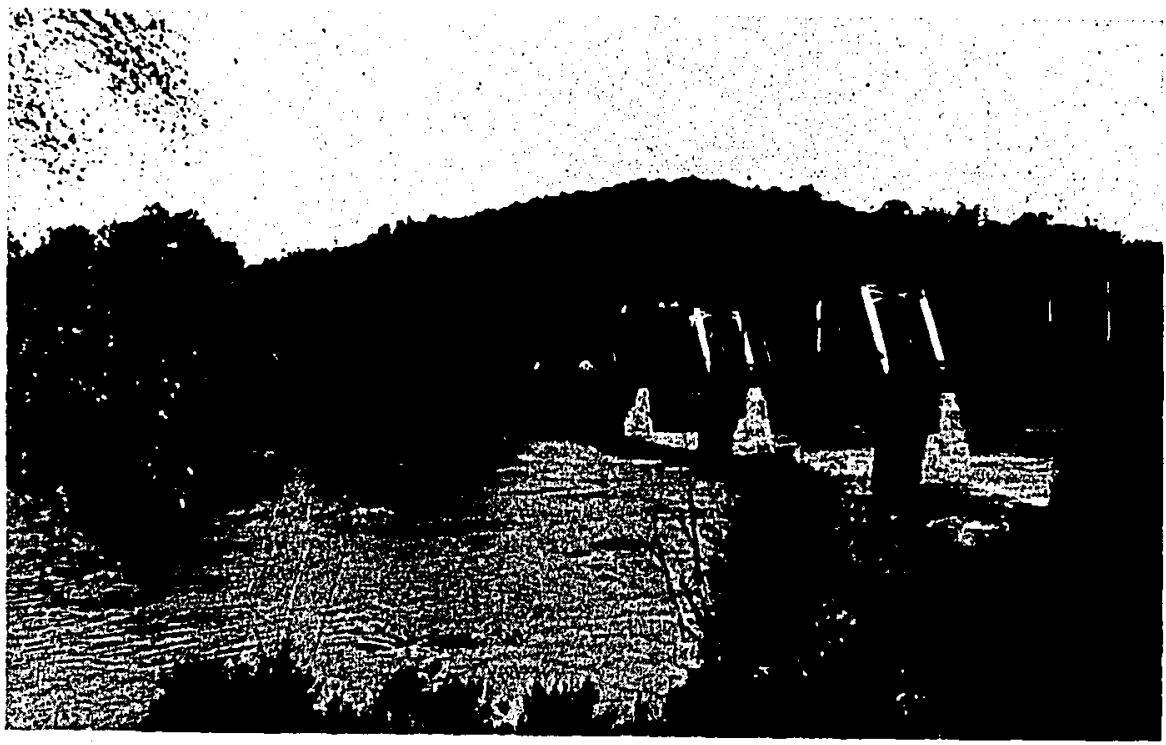

liig. 2.-Quartzite clilis near north end of bridge. Tooking northenst.

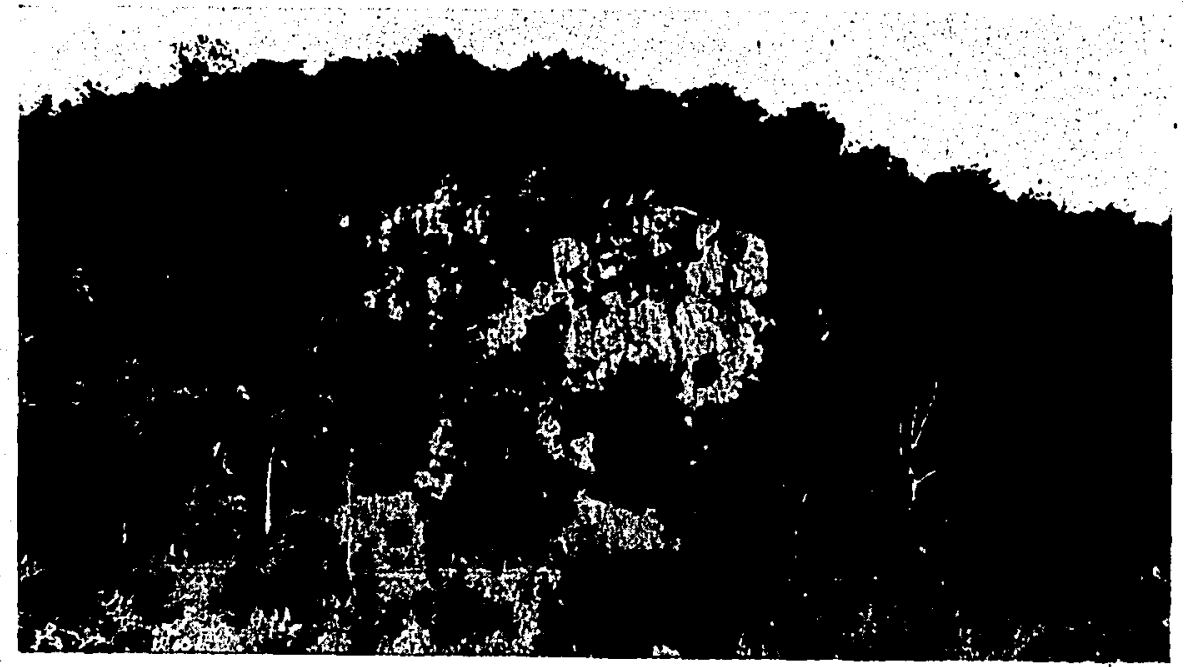

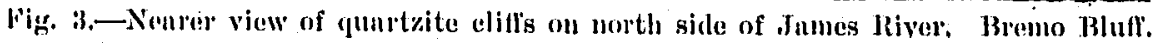

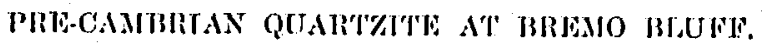


miles or more along its line of strike. The rock is white to light gray in color, when fresh, with a slightly pinkish tinge on weathering. It is quite free from impurities other than sericite, which is the only accessory mineral that can be distinguisherl with the naked eye. For a detailed microscopic description of this rock see pages 161-163.

London and Virginia mine.-At the London and Virginia mine there is a similar bed of quartzite, which in places is heavily impregnated witl pyrite and more or less gold. This bed of quartzite ranges up to 20 feet or more in thickness, and the series of outcrops and prospect pits located along its line of strike indicate that it is practically continuous for a distance of 10 or 12 miles. Specimens of this quartzite from the London and Virginia and the Bondurant mines are described on pages 189 and 193-194, respectively.

\section{Ferruginous Quartzite.}

GENERAL CHARACTER AND DISTRIBU'ION.

The ferruginous quartzites consist essentially of quartz, hematite, and magnetite. These three principal constituents vary greatly in their relative proportions, but quartz is usually dominant, though locally the iron oxides may constitute 80 or 90 per cent. of the mass. Some of the ironbearing quartzites contain a little sericite and biotite, and with the increase of these minerals the rocks pass into ferruginous schists.

The ferruginous quartzites are of more frequent occurrence than the pure quartzites, and are found interbedded with the other sedimentary rocks in almost every portion of the pre-Cambrian area.

\section{DISAILS OF OCCURRENCES.}

Webb tract.-On the Webb tract, about three-quarters of a mile southwest of Lantana, a bed of ferruginous quartzite has been prospected for iron, and is exposed in several surface pits that have been sunk. The bed is over 6 feet in thickness, has an approximate strike of N. $45^{\circ}$.E., and dips southeast at an angle of about $25^{\circ}$. It is interbedded with arkosicgneisses, quartz-sericite schists, and other beds of quartzite.

The rock is fine-grained, even-granular, and, when fresh, is brownishgray in color, turning to dark brown or black on weathering. It is composed essentially of quartz, specular hematite, and magnetite, but a little sericite may sometimes be recognized with the aid of a lens. It is slightly gneissic in structure, because of some recrystallization, accompanied by a partial segregation of the quartz and iron ores into narrow bands parallel 
to the bedding and schistosity. The magnetite in these segregated bands or layers, which are usually $3 \mathrm{~mm}$. or less in thickness, is somewhat conrser than that in the rest of the rock.

The quartzite is cut by numerous irregular quartz stringers, ranging up to 3 or 4 inches in width, and, for the most part, conforming to the strike of the enclosing rock. These quartz veinlets in places contain plates of micaceous hematite. Near the veinlets the quartzite seems to have heen leached of some of its iron content.

Examined in thin section (Spec. 95) under the microscope, the quartzite shows a slightly schistose structure due to the partial arrangement of the iron ores in parallel lines. The quartz grains average about $0.25 \mathrm{~mm}$. in diameter, and fit closely together, interlocking almost perfectly, but there is no evidence of granulation or optical distortion. The quartz individuals contain numerous small, dark red crystals of martite, the isometric form of lematite, which usually occur in well-formed octahedrons and are probably secondary (pseudomorphous) after magnetite. The larger masses of iron oxide are present between the quartz grains, and are frequently arranged in irregular, broken lines. Occasional hexagonal outlines show that a large proportion of the oxide is hematite, but much angmetite is also present. The fact that the quartz individuals in immediate contact with these larger masses of iron ore are practically free from the small inclusions, indicates that both the quartz and the iron ores have undergone recrystallization, accompanied by a partial segregation of the latter into larger masses. In places the iron ores are partly altered to limonite, and the boundaries between the quartz grains frequently show limonite staining. Considerable garnet (probably chiefly spessartite) is present, usually occurring as an interstitial filling between the quartz grains, and frequently along the contact between quartz and the iron ores. It is evidently secondary in origin, and, in some instances, appears to have partly replaced the quart\%. The garnets are usually full of small dust-like inclusions, and more or less stained with limonite. Small, light green to colorless inclusions of zircon are common but not abundant.

The Ayre tract.-On the Ayre tract, 3.5 miles east of Dillwyn, a large bed of ferruginous quartzite has been extensively prospected for iron ore by several shafts and open cuts. One of the shafts is 40 or 50 feet deep, the others being somewhat less.

The quartzite outcrops boldly, in places standing 6 to 8 feet above the surrounding surface, and along most of its course follows the crest of a 
ridge. The outcrops vary in width up to 200 feet or more, and the bed can be traced for over half a mile in a direction about $\mathrm{N} .45^{\circ} \mathrm{E}$.

'The rock is essentially the snme, both megascopically and microscopically, as that described above. Some of it is slightly coarser grained, and octahedral crystals of magnetite $0.5 \mathrm{~mm}$. in diameter can be distinguished in hand specimens. Sericite is sparingly present.

Spessartite is occasionally present in the quartzite, occurring in irregular and more or less angular masses that range up to a foot or more in diameter. These masses are reddish-brown in color, with a waxy luster, and the wenthered surface shows irregular, hackly cracks. Under the microscope (Spec. 420) the garnet is even-textured with few fractures and is seen to be full of extremely small inclusions. A few scattered grains of hematite are present, and with them there is often associated a little chlorite in fine, green shreds. The garnet is more or less stained by limonite.

The quartzite is cut by numerous stringers of vein quartz, frequently containing prisms of black tourmaline; and one specimen was found in which radiating clusters of tourmaline had penetrated the quartzite to a deptl of about $0.5 \mathrm{~cm}$. A large amount of tourmaline is present on the surface near the outcrops. A number of other occurrences of iron-bearing quartzite are reported southwest of this locality, in the vicinity of Willis Mountain.

The Scolia mine.-On the Scotia mining property, a bed of ferruginous quartzite, known as the Hodges vein, has been prospected for gold. 'The quartzite is cut by a number of small, gold-bearing veinlets, and has been slightly mineralized by the vein-forming solutions; otherwise it is identical with the other ferruginous quartzites of the district. The development work that has been carried out is sufficient to expose the marked lenticular shape of the deposit (see fig. 16, p. 171). A megascopic and microscopic description of the rock is given on pages 171-172.

Other localities.-Ferruginous quartzites occur at numerous other localities within the area mapped and thin sections from a number of them have been studied under the microscope, but as all of these are essentially the same, they will not be described in detail. At Cassell's mine 2 miles northeast of Caledonia a bed of iron-bearing quartzite 8 feet or more in thickness has been prospected by a surface pit. The rock exposed seems to have undergone greater recrystallization than most of the similar deposits in the area. It is described in detail on pages 174-175.

Ferruginous quartzite outcrops along the road three-quarters of a mile south of Stage Junction, where the bed has a strike of about N. $20^{\circ} \mathrm{E}$. 
Another occurrence is located on the road from Stage Junction to Pryors Crossroads, at a point three-quarters of a mile northeast of Big Byrd Creek. Outcrops also occur near the road between Palmyra and Wilmington, at Fork Union, and at several points in the vicinity of the Hughes mine. At the last-named locality some of the specimens have the appearance of hematite breccias recemented with magnetite and hematite.

\section{Garnetiferous Quartzites.}

GENERAL CHARACTER AND DISTRIBUTION.

Garnetiferous quartzites occur at several places in the district and are believed to be due to the metamorphic action of. igneous intrusire rocks on impure quartzites. Chemical tests prove that the garnets are the ironaluminum variety known as almandite. Sillimanite and sometimes a little cyanite are also present in association with the garnet. These rocks usually contain more or less hematite, magnetite, and sericite, and pass by gradation into the schists with which they are interbedded.

This type of rock has a limited distribution and was found only in the vicinity of contacts between the pre-Cambrian sediments and the intrusive granite.

\section{DETAILS OF OCCURRENOES.}

Lantana.-A bed of garnetiferous quartzite outcrops at Lantana, and for a mile southwest of the postoffice the road to Columbia follows approximately along the strike of this bed. It was traced in a northeast and southwest direction for a total distance of about 4 miles. The bed is probably not more than 10 or $\mathbf{1 5}$ feet thick and is usually much thinner.

The rock is banded in light and dark layers which range up to 2 or 3 inches in thickness. These layers are parallel to the bedding, the dark ones being composed largely of garnets while the light ones are chiefly of quartz. Radiating needles of sillimanite are common in places, and a little cyanite was identified. The garnets are dark red to brown in color, ranging up to about $0.5 \mathrm{~cm}$. in diameter, but show very poor crystal form. Under the microscope (Spec. 96) they are seen to be full of small inclusions consisting of quartz and oxide of iron. These inclusions are elongated and arranged in lines approximately parallel to the bedding. The garnets are much fractured, and are stained by limonite which also coats many of the quartz grains. The quartz shows evidence of considerable optical distortion and of extensive recrystallization. Near the garnets the grains of quartz are sometimes. arranged in bands that pass 
nround these crystals. There are a few flakes of sericite present, and the only other constituent noted was a soft white mineral that occurred as a coating and filled small cavities. It is probably some form of amorphous silica.

Weathered specimens of this rock often exhibit a hard surface crust having a rich reddish-brown color due to the presence of hematite, the iron of which has been leached from the partly decomposed minerals within, and reprecipitated near the surface.

The quartzite is interbedded with and grades into a fine-grained quartzsericite schist.

Stage Junction.-A bed of garnetiferous quartzite outcrops in the road about half a mile northenst of Stage Junction. It is more schistose than the rock near Lantana, but is otherwise the same.

\section{Hornblende-Bearing Quartzites.}

Quartzites containing a few crystals of dark green hornblencle occur at several localities close to the contact with the large area of intrusive granite, but they are of very limited distribution and therefore unimportant. The rocks placed in this classification are intermediate between the normal quartzites and the hornblende schists.

On the Columbia-Lantana road, three-quarters of a mile west of the bridge over Big Byrd Creek, there is an outcrop of hornblende-bearing quartzite. The rock contains blade-like crystals of hornblende, dark green to black in color, and ranging up to $3 \mathrm{~mm}$. in diameter, which are embedded in an even-granular ground-mass of quartz with a few scattered crystals of garnet and sillimanite. A similar rock was found at the Margaret mine near New Canton (see p. 250).

A fine-grained quartzite containing scattered prismatic crystals of dark green hornblende is exposed on the east side of Randolph Creek, where it is crossed by the road running from Lawford to Gold Hill. A similar rock was noted near Hatcher Creek about 3 miles west of Hatcher.

\section{Quartz-Sericite Schist. \\ GENERAL CHARACTER AND DISTRIBOJION.}

Schists composed essentinlly of quartz and sericite in varying proportions are of common occurrence in all portions of the pre-Cambrian series of sedimentary rocks, and constitute one of the most important rock types of the area. In texture these schists range from fine to medium coarse- 
grained, and in composition from sericite-bearing quartzites to rocks in which the mica is dominant. The finer grained varieties, containing much sericite, were described by the early geologists under the name of talcose schists. The coarser varieties, in which quartz is dominant, are very resistant to erosion and therefore frequently form the ridges and other higher elevations, outcropping with considerable prominence. The quartzsericite schists pass by gradation into the sericite-bearing gneisses, cyanite schists, and the ferruginous as well as the pure quartzites. Nearly all the schists found in this region contain more or less sericite, and there are numerous rocks intermediate in mineral composition between the quartzsericite schists and most of the principal varieties.

GENESIS.

The positive evidence of bedding and the gradation of the quartz: sericite schists into rocks, such as the quartzites, which are necessarily sedimentary in origin, leave no doubt as to the manner in which the schists were originally formed. The beds were probably laid down in shallow waters near the shore, partly in the form of quartz-feldspar sands and argillaceous sands, and partly in the form of finer sediments, possibly white clays. The present character of the rocks is due to their alteration under dynamic conditions in the zone of anamorphism, and certainly in some cases the change has been aided by the intrusion of the large granite magmas.

DETAILS OF OCCURRENOES.

Big Byrd Creek.-On the east bank of Big Byrd Creek, threequarters of a mile south of Bowles' bridge, and 11/4 miles east of Stage Junction, there is an exposure of quartz-sericite schist in which the ratio of quartz to sericite is so great that it is almost a quartzite. The rock (Spec. 33) is fine-grained and white to light yellow in color when not stained pink and red by oxides of iron. It is highly laminated parallel to the schistosity, showing well-marked layers which are slightly folded and crumpled. The minerals distinguishable under the microscope are quartz, sericite, a little feldspar, and occasional inclusions of zircon. The quartz grains fit closely together and show little optical distortion. The feldspars are chiefly acid plagioclase and in places they show partial alteration to sericite. Most of the mica flakes are perfectly oriented parallel to the schistosity.

Lantana.-For a distance of 500 or 600 yards southeast of Lantana the road passes across a belt of quartz-sericite schist, and this belt may be traced 
for 4 or 5 miles along its line of strike in a northeast and southwest direction, but in places it contains interbedded lenses of quartzite and other rocks. The schist (Spec. 42) is white to light gray in color, where not stained with iron, and usually fine-grained. Quartz is dominant over sericite, the flakes of which are all oriented parallel to the schistosity, so that when the rock is examined on surfaces at right angles to the cleavage it has the appearance of a quartzite rather than a schist. It is slightly banded, due to variation in the relative proportion of the quartz and sericite, and the layers show minor crumpling and folding.

A specimen (100) obtained from an outcrop $21 / 4$ miles northeast of Lantana, upon examination in thin section under the microscope, shows a little orthoclase and acid plagioclase feldspar, and occasional fluid inclusions and rutile needles. The feldspars show partial alteration to sericite and are much kaolinized.

About a mile northeast of Lantana occurs a rock which is intermediate in composition between the quartz-sericite schists and the ferruginous quartzites. It is a fine-grained schist, bluish-gray in color, in which few of the minerals can be distinguished by the naked eye. In thin section (Spec. 89) under the microscope it is seen to consist essentially of quartz, hematite, and sericite, with a few scattered crystals of nearly colorless amphibole and possibly a little cyanite. The quartz grains are irregular in shape, fit closely together, and show some optical distortion. The hematite is chiefly of the micaceous variety.

New Canton-Dillwyn road.-There are numerous outcrops of quartzsericite schist along the ridge road leading from New Canton to Dillwyn. This rock is slightly coarser grained than the schists previously described, and the schistosity usually has a crinkled or corrugated appearance. It is light greenish-gray to white in color, where not stained various shades of pink by iron oxides, and is composed essentially of quartz and white mica, with a small amount of light green chlorite, and occasional specks of specular hematite. It is very resistant to erosion and therefore outcrops prominently and forms the watershed between the streams flowing into Hunts Creek and Slate River, and those flowing into Phelps Creek and Willis River. Locally the schist is called mountain rock, because of its occurrence along the summits of the higher ridges.

A similar rock outcrops on Tower Hill, 21/2 miles south of Alpha and $31 / 2$ miles east-northeast of Dillwyn, and also on the slopes of Willis Mountain.

London and Virginia mine.-A fine-grained quartz-sericite schist is exposed at the London and Virginia mine and at the other mines that 
have been opened along the strike of the same vein. In this rock the percentage of sericite is high and is possibly dominant over the quartz. The schist, as well as the quartzite with which it is interbedded, has in places been heavily impregnated with pyrite. A detailed megascopic and microscopic description of the rock is given on page 186. A similar rock occurs in the mines near New Canton, and is especially prominent at the Hudgins mine (see p. 256).

Bondurant mine.-A quartz-sericite schist, which was found on the dump at the Bondurant mine, contains small lenticular eyes of light-blue opalescent quartz. This variety of the schist is similar to the hand specimen (211) obtained from the Scotia mine and described on page $\mathbf{1 7 0 .}$

Other localities.-Quartz-sericite schist is present along the road 3 miles northwest of $\mathrm{Ca}$ Ira and parallels the contact with the granitic rocks on the east for a distance of several miles in a northeast and southwest direction. It occurs in the road 2 miles south of Kent's Store, and also a quarter of a mile northeast of Byrd Creek on the road between Stage Junction and Pryors Crossroads; it outcrops on Byrd Creek, 11/4 miles north of Grays Mill, and in the road three-quarters of a mile south of Carysbrook; and it was noted along the road 11/2 miles south of Gravel Hill. There are numerous other occurrences in the area, but these are sufficient to show the wide distribution of this rock type.

\section{Cyanite Schists.}

GENERAI CHARACTER AND DISTRIBUTION.

The cyanite schists are composed chiefly of quartz, cyanite, and sericite or muscovite, and the relative proportions of these constituents vary within wide limits. There are all gradation from a rock composed almost entirely of cyanite, to one composed chiefly of coarse-grained quartz with only scattered prisms of cyanite; and these schists pass by gradation.into quartz-sericite schists in which cyanite is sparingly present or entirely absent. Cyanite is also present in some of the gneisses that have been intensely metamorphosed (see pp. 133 and 136-138).

The distribution of these schists is very limited and only two occurrences are known within the limits of the area mapped-one at Willis Mountain, and the other on the Trent farm, 31/2 miles southeast of Gravel Hill and 3 miles southwest of Hatcher. Similar schists have been described from the northwest corner of Charlotte County, about 25 miles southwest of Willis Mountain, and it is interesting to note that in each instance rutile is a prominent minor constituent. ${ }^{a}$

aWatson, Thomas L., and Watkins, J . H., Association of Rutile and Cyanite from a New Locality, Amer. Jour. Sci., 1011, vol. xxxii, pp. 195-201. 
While cyanite is softer than most rock-forming minerals, it is almost unalterable, and therefore the cyanite schists are extremely resistant to the agents of decomposition, and outcrop boldly at each of the localities in this section.

\section{GENESIS.}

The structural relations of the cyanite schists, wherever observed, are indicative of a sedimentary origin, and, moreover, cyanite is not known to occur as a pyrogenetic mineral. The chemical composition of these schists, consisting chiefly of alumina and silica, suggests that they must have been derived from kaolin or very argillaceous sediments, and this view is supported by the unusually high titanium content. Van Hise has called attention to the concentration of titanium in shales and other fine-grained sedimentary rocks. ${ }^{a}$ The metamorphic minerals composing these schists were produced in the anamorphic zone under conditions of dynamic regional metamorphism, but the location of both occurrences, not far from large areas of intrusive granites, suggests that contact action may have been an influential factor in bringing about the alterations. Evidence in favor of the latter hypothesis is furnished by the variation in the character of the schist in the vicinity of a peculiar diorite dike, which occurs on the southern slope, of Willis Mountain, and by the great abundance of tourmaline, chiefly ii association with vein quartz, found near the base of the mountain. The absence of cyanite, sillimanite, and similar minerals from most of the contact rocks is probably due to the presence of iron, magnesium, and the alkalies, which have resulted in the formation of amphibole and mica rather than the pure aluminum silicates.

\section{DETAILS OF OOOURRENCES.}

Willis Mountain.-The topographical features of Willis Mountain are described on pages 89-91, the formation of the narrow ridge being attributed to the structural and lithologic character of the bed of cyanite schist which outcrops along the summit. This rock was described under the name of "kyanitic gneiss" by Rogers, who states that it "differs from all in its vicinity, and appears to have been elevated from below through the surrounding slates;" faulting has been a factor in the formation of the mountain. The rocks

aVan Hise, C. R., A Treatise on Metamorphism, Mono. xlvii, U. S. Geol: Survey, 1004, pp. 974-975.

bRogers, W. B., Geology of the Virginias, 1884, pp. 314-315. (See also pp. 71-72. ind 200-201.) 
that constitute Willis Mountain offer greater resistance to erosion than any of the other rock types found in this region, and the gradual erosion of the softer rocks has left this ridge standing as a monadnock high above the level of the Piedmont peneplain. The rugged and cliff-like nature of the outcrops near the summit of the mountain is shown in Pl. IV, fig. 1.

The cyanite schist of Willis Mountain varies in texture according to the relative proportions of the two principal constituents-quartz and cyanite-and passes by gradation into the quartz-sericite schists with which it is interbedded. In places the rock is composed dominantly of cyanite, in large-bladed crystals, white to light gray or bluish-gray in color, and there are only minor amounts of quartz and sericite, the latter being sometimes practically absent; but elsewhere medium-grained saccharoidal quartz is predominant, with small prisms of cyanite scattered through the ground-mass. Rutile, occurring in small bright red grains disseminated indifferently through the other minerals, is the only remaining constituent which is ordinarily present, though tourmaline may occasionally be seen.

The cyanite crystals range up to 7 or $8 \mathrm{~cm}$. in length, and on the weathered surface stand out in high relief. Under the microscope (Spec. $386)$ the mineral is colorless, frequently shows a slightly radiating texture, the cleavage is well developed, and occasionally there is a little alteration to sericitc along the cleavage planes. Numerous irregular grains of rutile are present as inclusions, being usually arranged with their longer diameters parallel to the cleavage planes of the cyanite. The dominantly cyanitic variety of the schist has a noticeably high specific gravity.

On weathered surfaces the rock is often deep red to purple in color and much harder than at a distance of a few inches within the interior. This is due to the solution of the small amount of iron originally present, and its transportation by capillary attraction to the surface, where it is redeposited by evaporation, partly in the form of limonite and partly as hematite.

On the southern slope of Willis Mountain, in the immediate vicinity of a diorite dike, the cyanite schist has been extensively altered with the production of new minerals, such as light brown biotite, nearly colorless chlorite; plagioclase feldspar; and calcite. The rock is heavily impregnated with pyrite, and about 40 years ago two shafts were sunk in this material in prospecting for copper. The rock is described in greater detai] on page 114.

Trent farm.-On the Trent farm, 31/2 miles southeast of Gravel Hill and 3 miles southwest of Hatcher, there is a dike-like ledge of cyanite 


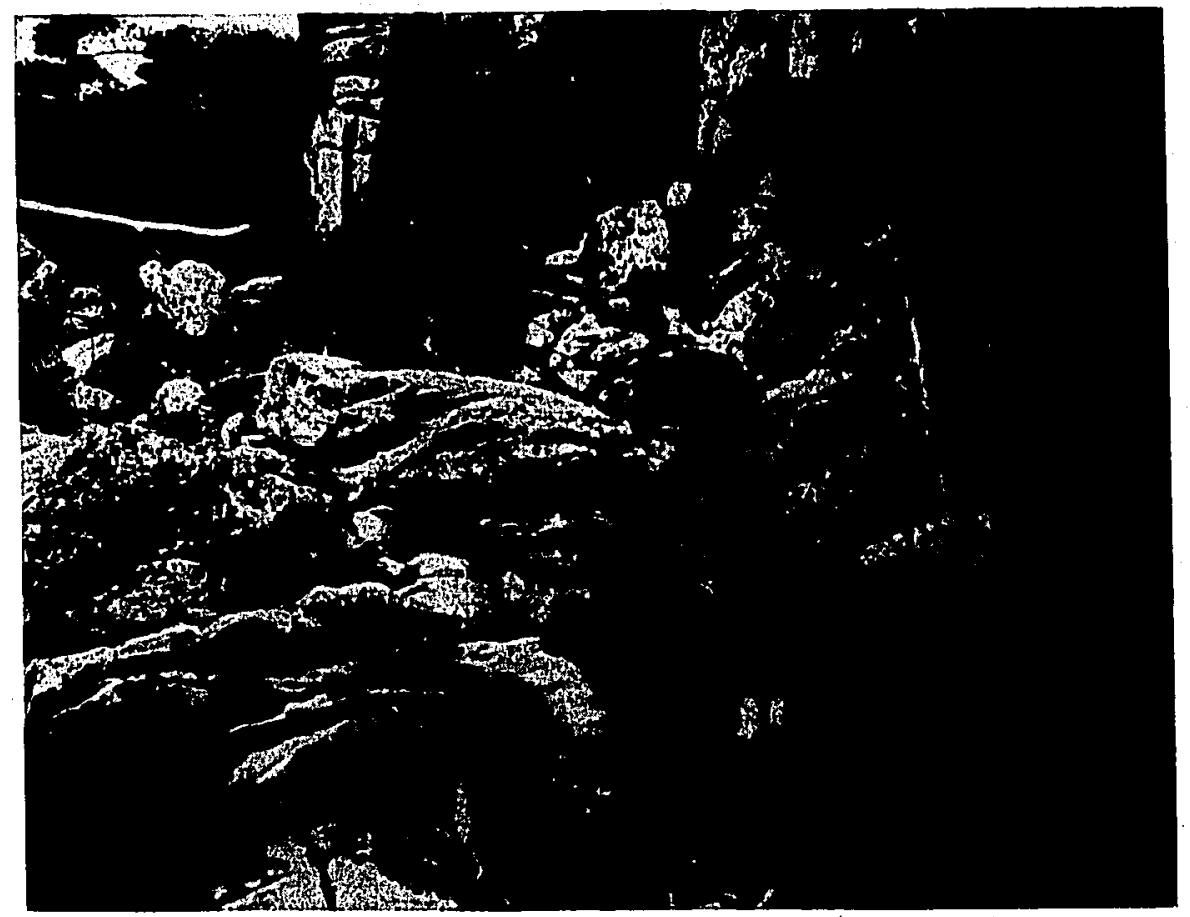

Wigr. 1.-Cynite schists onteropping near summit of Willis Mountuin.

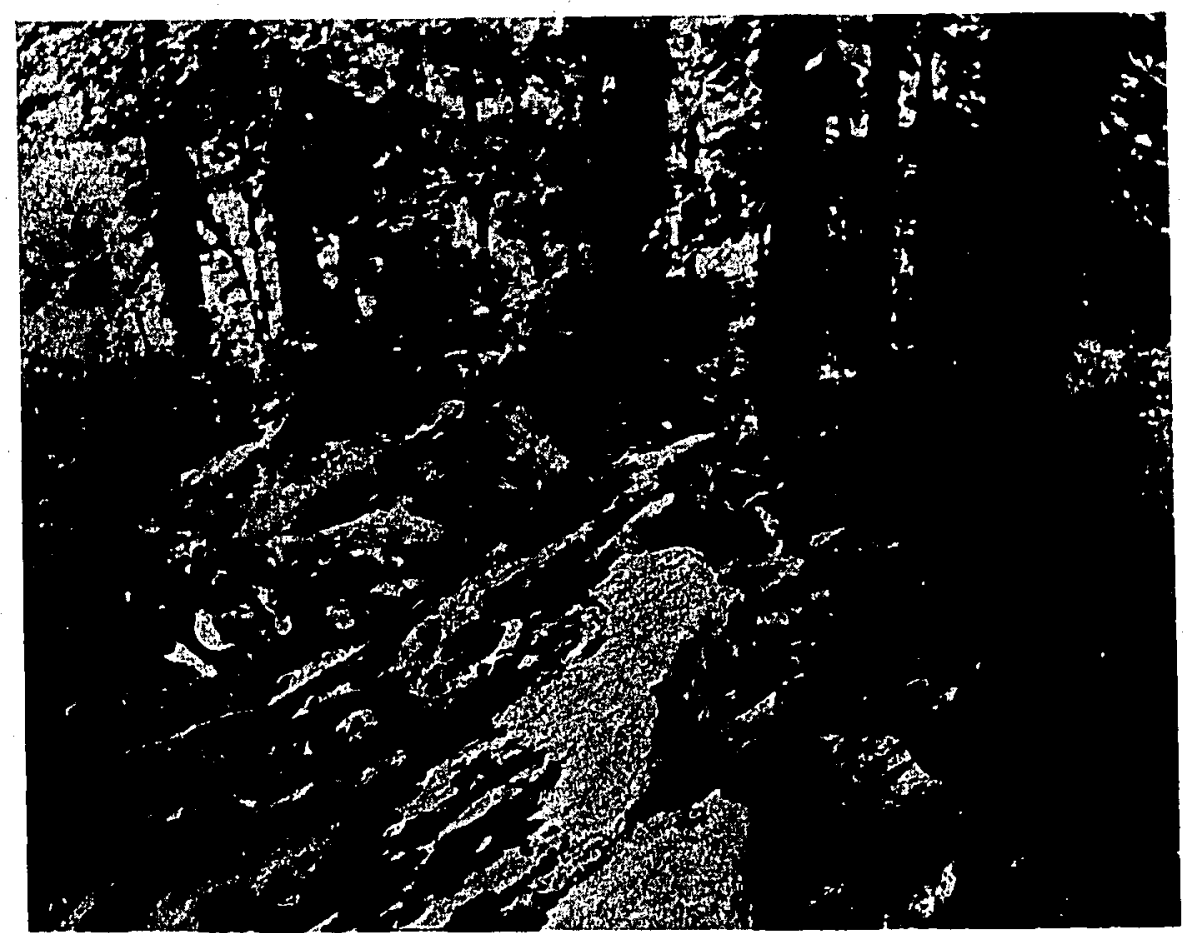

Fig. 2.-Cynnite sehists onteropping on the Trent farm. OUTCHOLS OH GANITE SCHIS'L. 
schist which outcrops for several hundred yards along the crest of a low ridge. It is 3 to 12 feet wide and in places stands 8 or 10 feet high, resembling a stone wall (see $\mathrm{Pl}$. IV, fig. 2), and, indeed, it has been used as part of a fence to restrain cattle. This bed of schist has a strike of N. $10^{\circ} \mathrm{E}$. and dips $30^{\circ}$ to $40^{\circ} \mathrm{E}$.

The rock is a heary, compact schist, pink in color, and composed essentially of cyanite, quartz, and sericite. The cyanite occurs in flatbladed prisms ranging up to 2 or $3 \mathrm{~cm}$. in length, the quartz is mediumgrained with a saccharoidal texture, and the sericite is present in small, glistening flakes. Examined under the microscope (Spec. 393), the cyanite is colorless, occasionally shows polysynthetic twinning, and in places is partly altered to sericite. Rutile is sparingly present in small grains, and a little titanite was noted in some of the quartz individuals. Fairly well formed zircons are also present as small inclusions in the quartz, and there is a little limonite, partly occurring as a stain on the other minerals.

The cyanite schist is interbedded with a medium-grained quartz-sericite schist (Spec. 394), white when fresh, and light brown to pink when stained with iron. Examined under the microscope, cyanite is seen to be present as a subordinate constituent and frequently shows multiple twinning with indefinite boundayies between the twins. Limonite is present as a stain along the contacts between the individual minerals, and also occurs in minute spherulites. A few inclusions of zircon are present in the quartz.

\section{Knotted Schists,}

GENERAL CHARACTER AND DISTRIBU'TION.

Knotted schist is the name given to a series of fine-grained rocks, composed essentially of quartz, sericite, chlorite, and biotite, in which there are numerous pseudophenocrysts of garnet, biotite, carbonate, or pyritethe latter minerals being of later formation than the schistosity of the rock. These large crystals were formed under mass static conditions, after the movements which produced the cleavage of the rock had ceased, for they show absolutely no parallelism in their orientation. They began to crystallize about favorable nuclei, and as they grew, the folia of the schist were gradually pushed aside, so that lenticular eyes or knots were formed, about which the enclosing folia are smoothly curved. The development of these minerals furnishes a very pretty illustration of the force exerted by growing crystals. 
When the knotted schists are examined in thin sections under the microscope, it is seen that the minerals of the ground-mass have made room for the crystals of later growth partly by bending and partly by recrystallization. The micaceous minerals of the ground-mass are imperfectly arranged in thin layers or bands, which alternate with layers composed of quartz grains elongated parallel to the schistosity. Opposite the pseudophenocrysts, the layers of mica are pushed close together (see Pl. V, fig. 1, and fig. 21, p. 227), while the quartz which has been removed from these points has recrystallized in the ends of the lenticular eyes. In other words, the quartz has acted very much as ice does under pressure-it has gone into solution where the pressure was greatest and recrystallized where the pressure was least; and this transfer of material was undoubtedly brought about by the small amount of interstitual water present in the rock. In recrystallizing, the quartz grains have been partly arranged with their greater diameters oriented in directions pointing toward and away from the pseudophenocrysts, so that in thin sections cut parallel to the schistosity the quartz grains surrounding one of these larger crystals have a radiating texture (see $\mathrm{Pl}$. V, fig. 2 , and fig. 22, p. 228).

The particular kind of mineral present in the lenticular knots seems to vary with their distance from the contact of the sedimentaries with the later granite intrusives; near the contact garnets are present, farther away biotitecrystals take the place of the garnets, and at greater distances impure crystals of siderite form the chief constituent of the lenses. These facts will be considered at greater length in the detailed descriptions of individual occurrences and in the discussion of metamorphism (see p. 107).

The knotted schists always have a fine-grained grotind-mass, and in places they closely approach slates, both in fineness of texture and in perfection of cleavage-in fact they have commonly been described as slates; but, since the principal mineral constituents can usually be distinguished with a pocket lens, it has been thought best in this report to classify them all as schists.

The knotted schists constitute one of the most important members of the pre-Cambrian series of sedimentaries, and have a maximum thickness of perhaps 5,000 feet or more. They are interbedded with the other schists and quartzites, and are found in three principal belts. These belts are described below in detail.

DETAILS OF OOCURRENOES.

New Canton.-The best exposures of the knotted schists are furnished by the bluffs along the south side of James River in the vicinity of New 


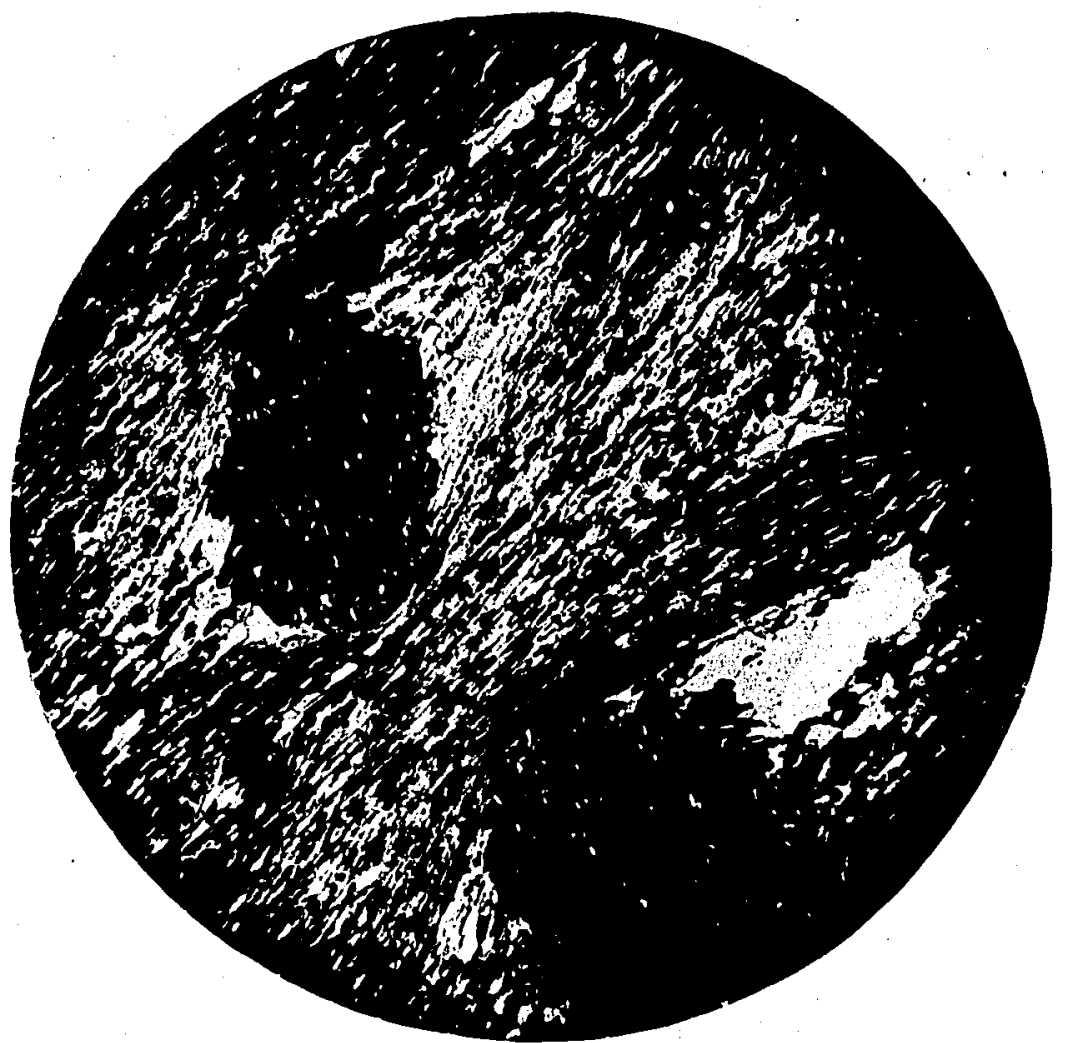

Figr. 1.-Photomierograph of biotito-bentring kmotted sehist; thin section cut perpendicular to the schistosity. With anily\%er. Mngnilied 27 diumeters. See puge 32. Sperimen No. :30T.

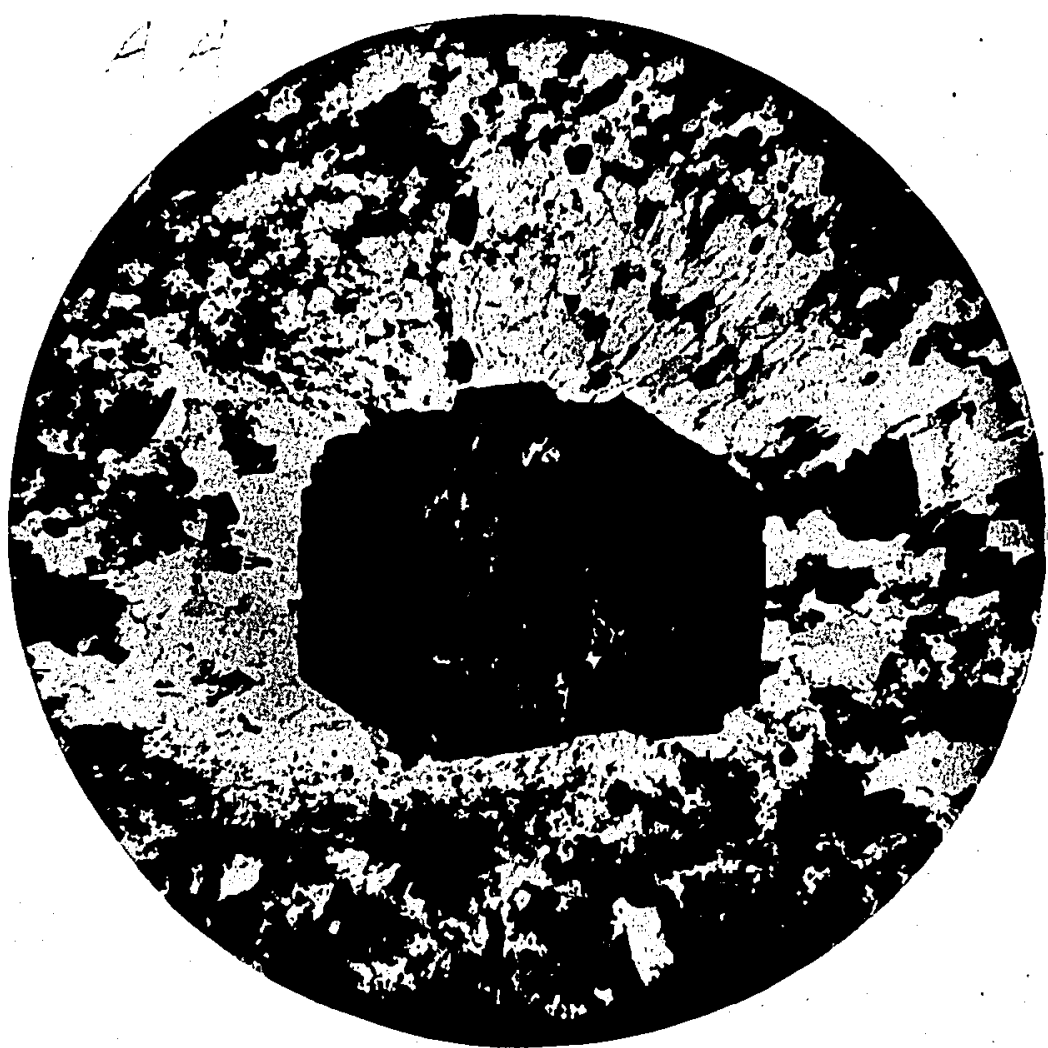

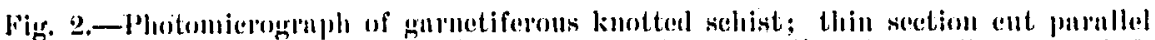
to the schistosity. With anulyzer. Mngnilied 27 dinmeters. Seo funge los. Specimen No, 178. Telluriun Mine.

pHOTOMITHOGHAPHS OF KNOTTED SCHISTS. 
Canton. Here the schists are interbedded with the quartzites described on pages 16-18, and the whole formation is upturned so that the beds are now dipping almost vertical. The average strike is about N. $20^{\circ} \mathrm{E}$.

On the east, these schists extend almost to the railroad bridge over Phelps Creek, where they pass into the belt of hornblende schists that occurs along the contact between the granite and the older sedimentaries. This contact and the rocks in its vicinity are described in detail under contact metamorphism on pages 107-112. Near the bridge over James River the schists are interbedded with several beds of quartzite, and west of these the schists continue as far as the belt of Ordovician sedimentaries. The total breadth of the formation is nearly $11 / 2$ miles and the whole series is apparently conformable, though it is possible that there has been some close folding resulting in repetition of beds.

The river bluffs and the railroad cuts along the line of the Buckingham Branch of the Chesapeake and Ohio Railway, furnish an almost continuous exposure across the entire formation. The schists on the west side will be described first, as these are farthest from the contact with the granite, and then the variations that are encountered in passing eastward across the formation will be considered in detail.

The rock exposed 1,200 yards west of Bremo bridge and about 2,000 yards west of the contact with the granite, is a fine-grained knotted schist (Spec. 445), dark bluish-gray in color, containing lenticular eyes of impure siderite ranging up to 4 or $5 \mathrm{~mm}$. in diameter. In fineness of texture this rock closely resembles the slates of the Ordovician formation, and but for the fact that it passes by gradation into the true schists, it would probably be preferable to classify it as slate. The rock shows a closely spaced fracture cleavage, which intersects the flow cleavage and bedding at an angle of nearly $90^{\circ}$. Considerable pyrrhotite is present, sometimes forming small lenses, and there are occasional narrow veinlets of calcite. The ground-mass is composed essentially of the micas-chiefly sericite, quartz, and a little carbonate and iron oxide.

A specimen (444) obtained from an outcrop about 1,000 yards west of the bridge is typical of most of the schist found at a distance from the contact. The rock is fine-grained, but is slightly coarser in texture than the specimen last described, and the color is a much lighter shade of gray. It contains numerous small knots due to the presence of lenticular eyes of impure siderite, averaging about $1 \mathrm{~mm}$. in diameter, and a little pyrite and pyrrhotite can be distinguished with the aid of a lens. The rock is cut by occasional veinlets of calcite, usually less than half an inch in thick- 
ness, which sometimes show slight symmetrical banding. In thin sections under the microscope the lenses of siderite are seen to be stained with limonite and to contrin numerous inclusions of quartz and a few grains of iron oxide and sulphide. The ground-mass is composed essentially of quartz, sericite, and carbonate, with lesser amounts of pyrite, pyrrhotite, iron oxide, chiefly hematite, acid plagioclase feldspar, dark brown prisms of tourmaline, zircon, and a little chlorite.

Schists that are identical in every way with the specimen just described occur within 200 yards of the bridge and are interbedded with the quartzites. Near the bridge, which is about 1,000 yards from the contact, biotite and chlorite begin to take the place of the siderite in the lenticular knots, and it is believed that these changes are chiefly due to the metamorphic action of the granite. From this point eastward the schists show rapidly increasing evidence of contact metamorphism.

A specimen (49) ${ }^{a}$ from the bluffs about 25 yards west of the bridge is, megascopically, closely similar to the schists already described, but under the microscope it may be seen that many of the knots are composed of biotite, chlorite, and quartz instead of siderite. Lenses of siderite, stained with limonite, are however still present. The ground-mass contains sericite, quartz, chlorite, biotite, pyrite, iron oxide (hematite?), a few small prisms of green and brown tourmaline, zircon, and probably a little feldspar.

A specimen of knotted schist (307) obtained from the bluff 400 yards southeast of Bremo bridge and about 800 yards from the contact, contains numerous rounded crystals of biotite, averaging 1 to $1.5 \mathrm{~mm}$. in diameter, and, rarely, small pink garnets of nearly the same size. The crystals of biotite are dark brown to black in color and the direction of cleavage, which is independent of the schistosity of the rock, shows no regular orientation. They closely resemble the crystals of ottrelite which sometimes occur in similar schists. The ground-mass is slightly coarser in texture than the specimens previously described, and the minerals-quartz, mica, and magnetite -can be distinguished megascopically.

Under the microscope, as shown in Pl. V, fig. 1 , the crystals of biotite are seen to have an irregular, ragged outline and a micropoikilitic texture due to the numerous inclusions of quartz. In places these inclusions are so plentiful that they give to the mica an appearance resembling lace-like network. The biotite is dark brown in color and strongly pleochroic. The ground-mass is composed essentially of quartz and sericite with a little

aSpecimen collected by Dr. T. P. Maynard. 
chlorite, biotite, less magnetite, and, rarely, plagioclase feldspar. The quartz occurs in elongated grains, interleaved with fine shreds of sericite, all being perfectly oriented parallel to the schistosity. The small grains of magnetite show a similar elongation parallel to the schistosity, and the slide also contains clouds of uniformly distributed, dust-like inclusions, probably black iron ores, though they are too small to make identification positive. The shreds of sericite, over large areas, extinguish simultaneously except where they curve around the large biotite crystals, and there the change is gradual. This gives the thin section a brilliant appearance between the crossed nicols. Where the flakes of sericite curve around the biotite crystals they are pushed close together, and the interstitial quartz, which has been largely removed from these points, is concentrated immediately in front and behind the biotite, in grains that are somewhat larger than those of the ground-mass.

In passing eastward toward the contact, the crystals of biotite present in the lenticular knots gradually give way to garnets, and the ground-mass becomes a little coarser. At a distance of about 600 yards southeast of the bridge the garnets are numerous and well developed, while the biotite crystals are absent or only sparingly present. Within less than 100 yards from this point the rocks are close-textured, less easily cleavable, and contain much hornblende (see p. 109). A specimen in which the garnets greatly predominate over the biotite crystals (319-A) was obtained from the Johnson mine near New Canton, and is described in detail on pages 254-255.

Rogers described the schists in the vicinity of Bremo under the name of bird's-eye maple slate. His statement is as follows:

"After leaving the gneiss and hornblende slate a little below Bremo, we come upon heavy vertical beds of a Alicaceous slate, in which are multitudes of half-developed garnets, and sometimes crystals of cubical pyrites - giving to the surface of the rock the appearance of numerous knots, around which the fibres of the stone are beautifully curved, so as closely to resemble the shading of the bird's-eye maple." a

The belt of knotted schists, that has just been described, extends from the river in a northeasterly direction for a distance of over 6 miles. At the Snead mine, a mile north of Fork Union, a knotted schist is exposed which contains pseudophenocrysts of both garnet and biotite. The belt extends as far south as Willis Mountain and possibly much farther, but good exposures are seldom found after leaving the river. The belt of knotted schists passes just west of Gravel Hill, and crosses the road about

aRogers, W. B., Geology of the Virginias, 1884, p. 78. 
$11 / 2$ miles south of Dillwyn. In this southern portion of the area, the knots in the schist do not seem to be as well developed as farther north, but this may be more apparent than real, for all of the rock examined was partly decomposed.

Strathmore. - On the west side of Bremo Creek, about 1,000 yards west of Strathmore, there is an outcrop of knotted schist containing welldeveloped lenticular eyes of siderite. The rock is more schistose than the similar schists a mile west of Bremo bridge, but it is otherwise the same. It outcrops at several points to the northeast and apparently extends for a distance of 5 miles or more in that direction, but on the south side of Slate River it was not found. This belt of knotted schists, while separated from the one that was first described by the intervening Ordovician formation, undoubtedly belongs to the same series and owes its present position to folding and faulting.

The Tellurium schists.-The third belt of knotted schists outcrops in the road at Shannon Hill and may be traced in a southwest direction nearly to Big Byrd Creek. It is best exposed in the underground workings at the Bowles, Tellurium, and Scotia mines. A representative specimen (178) from the Tellurium mine is described on pages 168-169, and a photomicrograph is shown in $\mathrm{Pl} . \mathrm{V}$, fig. 2.

Stage Junction.-A bed of micaceous schist, about 300 yards wide, is exposed near Stage Junction. It has a strike of N. $20^{\circ}$ E., dipping nearly vertical, and was traced for over $11 / 2$ miles. No fresh specimens could be obtained, but the weathered material indicates that the rock is similar to the knotted schists found elsewhere in the area.

\section{Hornblende Sohists.}

general character aND distribution.

Hornblende schists, that are unquestionably sedimentary in origin, occur at a number of places in the pre-Cambrian area, but the origin of many of the hornblende schists is doubtful, and most of them are probably. derived from igneous rocks. Because of the general character and structural relations of these rocks, as well as their distribution relative to the later granites, it is believed that the formation of hornblende schists from sedimentary rocks was due chiefly to contact metamorphism, rather than to regional dynamic metamorphism. Hornblende schists are commonly present along the contact between the igneous and sedimentary rocks; and the few outcrops that were found at a distance from known 
occurrences of granite, may be explained by lack of exposures, though in some localities it is possible that erosion has not yet progressed far enough to expose the underlying granite.

As it is seldom possible to distinguish between the hornblende schists that are sedimentary in origin and those that are igneous in origin, and as the majority of these rocks belong to the latter class, most of the occurrences will be described under igneous rocks.

\section{DETAILS OF OCCURRENCISS.}

New Canton.-One of the best exposures of hornblende schist is furnished by the bluffs along Phelps Creek in the vicinity of New Canton. These schists occur along the contact between the sedimentary schists and quartzites on the west, and the granites and their accompanying differentiates on the east. Since this is the best exposed section crossing the contact, and since the schists that are sedimentary in origin grade, without noticeable change, into the hornblende schists that represent a basic border facies of the granite, a detailed description of all the rocks in the immediate vicinity of the contact will be given under the discussion of contact metamorphism (see pp. 109-112), and nothing further need be said here concerning them. These same hornblende echists are well exposed at the Johnson mine'and are described on pages 248-250 and 255-256.

Big Byrd Creek.-At the horseshoe bend in Big Byrd Creek, threequarters of a mile east of Stage Junction, there is an outcrop of finegrained hornblende schist, which is believed to be sedimentary in origin. The strike of the formation at this point is N. $35^{\circ}$ E. and the dip is $40^{\circ}$ S. E. The schist has a well-developed slaty cleavage, which is so marked that it led the owner of the property to prospect the outcrop in the hopes of developing good roofing slate. A garnetiferous quartz-mica schist occurs on the west side of the hornblende schist, and a short distance to the east there are outcrops of quartz-sericite schist. A large dike of diabase cuts the schists about 200 yards from the creek, but has in no way affected the rocks with which it is in contact.

Megascopically the rock is dark gray to green in color, with a finegrained, even-granular texture, and in places the cleavage planes show lens-shaped spots or blotches, $0.5 \mathrm{~cm}$. in length, which are composed of biotite and chlorite. Small needles of black hornblende and white granular quartz are the principal constituents distinguishable by the naked eye, but some of the rock contains considerable evenly distributed biotite. Occasionally the schist is banded in light- and dark-colored layers parallel to the schistosity; the dark-colored layers being due to the presence of much hornblende and biotite, and the light ones to an excess of qunrtz. A little pyrite may also be identified in places. 
In thin section (Spec. 51) under the microscope the rock is seen to be composed of dark green hornblende, quartz, feldspar, magnetite, biotite, and chlorite. The hornblende occurs in narrow prismatic crystals, ranging up to $2 \mathrm{~mm}$. in length, which show good cleavage and strong absorption, the colors being various shades of brown, blue, and green. The quartz and feldspar are present in small clear grains, filling the interstices between the hornblende, and they: occasionally contain small included needles of hornblende. The quartz and feldspar have the same index of refraction and are distinguishable with difficulty, except where the latter mineral shows eridence of cleavage. The magnetite occurs in clusters or aggregates of small irregular grains. The biotite is greenish-brown in color and shows partial alteration to chlorite.

Lantara.-The contact between the igneous and sedimentary rocks crosses the road about half a mile southeast of Lantana, and it is marked by: a belt of hornblende schists that are similar to those occurring near New Canton. Exposures of fresh rock are rare in this vicinity, but along the branch, a mile northeast of Lantana, there are several outcrops of hornblende schist.

A partly decomposed rock, outcropping on the left bank, is medium coarse-grained and dark green in color. The mineral constituents recognizable megascopically are dark green hornblende, quartz, probably feldspar, and a little garnet, and chlorite. A prismatic mineral (probably tremolite), which is light green to brown in color, is also presenit.

A specimen (90) obtained from the opposite side of the branch is finer grained and much fresher. It is an even-granular, dark greenish-gray schist, in which amphibole, quartz, pyrite, and magnetite are the principal constituents. Part of the amphibole is green in color, but much of it is light gray to nearly colorless, and is doubtless tremolite. In thin sections under the microscope, the amphiboles are all colorless in natural light, and between the crossed nicols most of them show rather high interference colors. Twinning is sometimes shown. There is also a little acid plagioclase present, which is usually unstriated and therefore difficult to distinguish from the quartz.

\section{Gneisses.}

GENERAL OHARAOTER AND DIBTRIBUTION.

Gneisses, believed to be sedimentary in origin, are found only in one portion of the area of pie-Cambrian rocks, namely, along the eastern border, north of James River, in the vicinity of Lantana. These gneisses are best exposed along Big Byrd Creek, between Bowles' bridge, 11/2 miles 
northeast of Stage Junction, and the contact of the sedimentaries with the granites, nearly two miles below. Away from the creek there are few outcrops; but float is present in many places, being especially abundant near the branch $11 / 4$ miles northenst of Lantana, and the underground workings of the Ioung American mine furnish excellent exposures of fresh material. All of these gneisses are confined to the area of metamorphosed sedimentaries lying on the southeast side of an imaginary line, which extends from a point on Big Byrd Creek, a few yards above Bowles' bridge, in a northeast direction through Pryors Crossroads. No knotted schists are found on the southeast side of this line. It appears certain that the areal distribution of the sedimentary gneisses was once much greater than at present, and they probably extended for a considerable distance toward the northeast and the southeast; but the greater part of these beds has long since been removed by erosion.

Two principal varieties of gneiss were recognized-one light in color and composed for the most part of quartz, feldspar, and sericite; the other dark-colored because of the presence of more or less biotite and dark green hornblende. Both usually show well-developed banding. These two varieties occur interbedded with one another, and with beds of sericite quartzite, ferruginous quartzite, and quartz-sericite schists. The darkcolored gneiss is confined to the northwestern side of the belt and is the dominant rock exposed in the openings at the Young American mine, but its areal distribution is not so extensive as that of the lighter variety.

GENESIS.

The manner in which these gneisses are interbedded with one another and with the quartzites, leaves no doubt as to their sedimentary origin. Anaylses of both the dark- and light-colored gneisses, made from samples taken 100 feet below the surface at the Young American mine, are given on page 124. The analyses show a striking resemblance in chemical composition between these metamorphosed sedimentaries and igneous rocks of the quartz-diorite family. It is therefore probable that the sediments were derived from a land area composed chiefly of such rocks, and that they were laid down in comparatively shallow waters close to the shore. The conditions under which such material was derived did not permit mature decomposition; the land area was probably poorly covered by vegetation, rock disintegration was rapid, and the material formed was quickly removed and redeposited without appreciable sorting. The sediments laid down in this manner formed beds of arkosic sandstones and grits; and the present character of the rocks is due to dynamic regional metamorphism, aided by the intrusion of the granitic rocks that partly surround and probably underlie these altered sediments at no great depth. 
DETAILS OF OCOURRENOES.

- Young American mine.-The freshest exposures of both the light and the clark varieties of gneiss were found in the lower workings of the Young American mine; and detailed megascopic and microscopic descriptions of these rocks, together with chemical analyses, are given under the description of this property (see pages 122-139). The difficulty of obtaining fresh material-for microscopic study and chemical analysis-may be appreciated when it is stated that, in the Young. American mine, some of the rock is badly decomposed to a depth of nearly 100 feet below the surface.

Bowles' bridge.-On the road between Stage Junction and Pryors Crossroads, near the bridge over Big Byrd Creek, there are well-exposed outcrops of light gray gneiss. The rock (Specs. 39 and 40) is fine-grained, even-textured, and slightly banded; both in the hand specimen, and in thin section under the microscope, it closely resembles a fine-grained granite-gneiss. It is composed essentially of quartz, orthoclase and acid plagioclase feldspars, and sericite. Much calcite, probably secondary in origin, can be distinguished under the microscope; biotite is present in small dark green flakes, partly altered to chlorite; and small amounts of pyrite, magnetite, and zircon constitute the minor accessories. Some of the quartz grains show undulatory extinction, but for the most part there is little evidence of optical distortion or granulation. The sericite occurs in fairly large flakes, containing numerous inclusions of quartz, and it is partly of later origin than the schistosity.

About 400 yards below the bridge there is an outcrop of dark gray gneiss (Spec. 35), which is apparently identical in mineral composition as well as in texture with much of the rock exposed in the Young American mine. It is fine-grained, closely banded in layers of light and dark minerals, and composed for the most port. of quartz, feldspar, biotite, chlorite, sericite, and occasional garnets. Elsewhere in the same vicinity the rock contains much dark green hornblende.

Bertha and Edith mine.-On Big Byrd Creek, about 1,000 yards south of Bowles' bridge, there is an exposure of light gray gneiss (Spec. 32) similar in appearance to that at the bridge, except that it is slightly conrser grained. Much of the sericite occurs in large flakes in which the cleavage is not parallel to the schistosity, showing that it is of later formation than the movements which metamorphosed the sediments. The minerals present, in the order of their relative abundance, are quartz, feldspar, chiefly acid plagioclase, sericite, biotite, chlorite, magnetite, pyrite partly altered to limonite, zircon, and titanite. Calcite was not identified. 
On Big Byrd Creek, a mile south of Bowles' bridge, the gneiss. (Spec. 30 ) is a light gray, fine-grained rock, differing but little from the specimens previously described. It contains less sericite, and under the microscope considerable epidote or zoisite can be detected.

Where the road entering the property crosses Great Camp Branch, there is an outcrop of the light gray gneiss, which is within about 300 yards of the contact of the sedimentaries with the granite. The rock (Spec. 48) is composed of quartz, feldspar, and sericite, with lesser amounts of biotite, partly altered to chlorite, garnet, zircon, and magnetite.

Belzoro mine.-Near the branch half a mile north of Lantana, there are numerous pieces of the light gray gneiss lying loose on the surface, but there are no outcrops of rock in place. The same material is plentifu] in the vicinity of the other branch, nearly a mile to the northeast. This gneiss (Spec. 85) is slightly banded, and, except for the sericite, is finegrained. Some of the areas of sericite are a centimeter in diameter, and as the orientation of the cleavage is independent of the schistosity of the rock they must be of later formation. Even in the hand specimen the flakes of sericite are seen to be full of included quartz grains. Under the microscope the rock is seen to be composed chiefly of quartz, sericite, feldspar, with' lesser amounts of biotite, partly altered to chlorite, epidote, garnet, magnetite, zircon, and rutile needles. Some of the feldspars show partial alteration to sericite, and this is probably the chief source of the mica. In places the sericite shows intergrowths with biotite. Zircon and rutile needles are very plentiful as inclusions in some of the quartz.

\section{ORDOVICLAT.}

\section{General Statement.}

The Ordovician rocks are for the most part confined to a long narrow belt, which extends in a northeasterly direction from a point near Alpha, a station on the Buckingham Branch of the Chesapeake and Ohio Railway, to Carysbrook, a station on the Virginia Air Line Railway. A small elongated area of the same formation, located along the upper portion of Long Island Creek, between Palmyra and Wilmington, is in approximate alignment with the larger belt; and it seems most likely that the two areas were formerly continuous, and that they have been separated by the erosion of Rivanna River, which has removed the overlying sedimentary rocks, exposing thie granite beneath.

Another small area, which parallels the main belt for a short distance. has been prospected for slate at a point about 2 miles north of Forli 
Union Station. It was undoubtedly connected at one time with the main area, and has become separated through folding and erosion.

The principal belt has a maximum width near James River of over a mile, but it probably averages less than half a mile; the total length, including the detached area on the northeast side of Rivanna River, is about 22 miles.

The Ordovician series, where complete, consists of a thin bed of conglomerate, overlain by a few feet of impure quartzite, and then followed by several hundred feet of slate. In places the conglomerate is composed of mashed pebbles of pre-Cambrian schist, and when these are small, the fragmental character of the rock is distinguishable with difficulty. At one point a layer of tuffaceous material, a few feet thick, occurs interbedded with the slates.

The discovery of crinoids in slate from the Arvonia quarries was announced in 1892, and from a study of these fossils Dr. Walcott reached the conclusion that they belonged to the Trenton-Lorraine or upper portion of the Ordovician fauma. ${ }^{a}$ Later brachiopods and trilobites were found, and, according to Dr. R. S. Bassler, the twelve species which have been identified "make up an assemblage of forms which seems to be of middle Cincinnatian age."

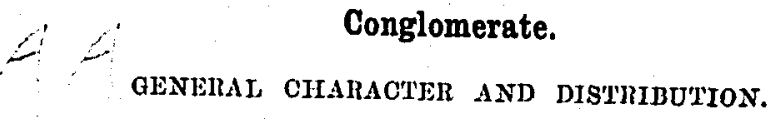

'The conglomerate occur's only at the base of the Ordovician rocks, where it rests upon the eroded surface of the metamorphosed, preCambrian sediments and in places upon the granite. On the south side of James River the conglomerate is found along the southeastern boundary of the slate area, but has not been observed on the northwest boundary. It is not exposed in the section furnished by the bluffs along the river, probably because of minor faulting, which is very marked in the vicinity of the place where the conglomerate would be expected to appear. It outcrops, however, within about half a mile of the bluffs and can be traced southward for a distance of several miles. On the north side of the river the conglomerate was observed only on the west side of the slate, occurring on the road between Palmyra and Wilmington, about a quarter of a mile west of Long Island Creek, and in the railroad cut half a mile south of Carysbrook. aDarton, N. H., Fossils in the "Archean" Rocks of Central Piedmont, Virginin,
Amer. Jour. Sci., 1892, vol, xliv, pp. 50-52.

"Vatson, Thomas L., and Powell, S. I., Fossil Evidence of the Age of the Virginia Piedmont Slates, Amer. Jour Sci., 1011, vol, xxi, pp. 33-44. 
The lack of suitable exposures makes it impossible in most places to determine the thickness of the conglomernte. Outcrops in the vicinity of Penlan indicate a possible thickness of perhaps 100 feet, but as the dip of the strata could not be determined at this point, the measurement means little. In the railroad cut south of Carysbrook the conglomerate is only a few inches thick and in places entirely disappears.

The composition of the conglomerate varies greatly in different portions of the area; in places it consists almost entirely of flattened pebbles of schist, but pebbles of vein quartz and of quartzite are usually present, and sometimes there is much magnetite, graphite, and other material. No granite or feldspar pebbles were found. 'The rock is usually schistose and, where the quartz pebbles are scarce, is easily mistaken for a preCambrian schist. The pebbles of vein quartz show no pressure effects, those of quartzite are usually more or less distorted, and all the softer material is pressed out flat.

\section{DETAILS OF OCOURRENCI:S.}

Penlan.-There are prominent outerops of conglomernte nlong the county road about three-quarters of a mile southeast of Penlan. 'The rock contains well-1'ounded pebbles of quartz and also of quartzite, ranging up to 2 or 3 inches in diameter; but for the most part it consists of a fine-grained, schistose ground-mass, which has been derived from pebbles of the neighiluoring pre-Cambrian schist. In places it is possible to distinguish flattened and almost obliterated fragments of quartz-sericite schist and of the slate-colored, knotted schist.

When the schistose ground-mass is examined under the microscope (Spec. 462 ), clear rounded grains of quartz, ranging up to $1.5 \mathrm{~mm}$. in diameter, can be distinguished in a ground-mass consisting chiefly of sericite, chlorite, quartz, and black oxide of iron. The larger quartz grains seem to have grown slightly at the expense of the surrounding material, for they have irregular outlines, with little spur's running out into the groundmass, and frequently contain numerous inclusions along their border portions. Gas and fluid inclusions are plentiful in some of the quart\%. Glistening plates of hematite, and a few grains of magnetite make up the remaining accessorjes.

Outcrops of conglomerate similar to that just described are exposed along the road running northeast and southwest, about half a mile southeast of Arvonia, and at numerous other points along the same line of strike.

Carysbrool:- In the railroad cut half a mile south of Carysbrook, the Ordovician sediments can be seen resting directly on the eroded surface of the granite (see PI. VI, fig. 1). There is in most places a thin line of pebbles in contact with the granite, but sometimes even this is absent. 
A bed of impure quartzite, about 10 feet thick, rests on top of the conglomerate, or where this is absent on the granite, and above the quartzite occurs the slate. The pebbles are chiefly of quartz, but fragments of slaty rock are present, and also much graphitic material. The latter is soft, disintegrating rapidly, and leaving cavities in the weathered surface. The pebbles are cemented together by fine-grained, impure quartzite.

Long Island Creek.-There is an outcrop of highly ferruginous conglomerate on the road between Palmyra and Wilmington, about a quarter of a mile west of Long Island Creek. The rock is dark gray, very schistose, and consists of flat, lens-shaped pebbles of quartzite, in a chloritic groundmass, containing a large amount of fine-grained magnetite. Under the microscope (Spec. 486) the magnetite apparently constitutes 40 or 50 per cent. of the mass, the remainder being made up of quartz, chlorite, and sericite, in the order named. The smaller grains of magnetite are commonly idiomorphic, but the larger grains, ranging up to 1 or $2 \mathrm{~mm}$. in diameter, are irregular in shape.

\section{Quartzite.}

The best exposure of Ordovician quartzite is the one which may be seen in the railroad cut, half a mile south of Carysbrook. The rock is only about 10 feet thick and varies somewhat in texture. It is nearly even-granular, slightly schistose, and of a light bluish-gray color. In thin sections (Specs. 509 and 510) under the microscope, the quartz grains show optical distortion and some granulation, and they have partly recrystallized so as to fill the interstitial spaces. They contain liquidand gas-filled cavities, and small black inclusions (iron oxide?) arranged in lines which pass across the quartz grains. In places these lines are very numerous, suggesting fractures that have been recemented. Sericite is the principal impurity, and there are occasional short prisms of brown tourmaline. Zircon and small rutile needles occur as inclusions in some of the quartz.

A bed of quartzite also outcrops in the road about half a mile southeast of Penlan, but its thickness could not be determined. It is separated from the conglomerate described on page 41 by a bed of schist which is probably formed chiefly from fragments of the pre-Cambrian schist.

\section{Sohist.}

A light gray schist, closely resembling some of the pre-Cambrian schists, outcrops in the road about half a mile south of Arvonia, and not 


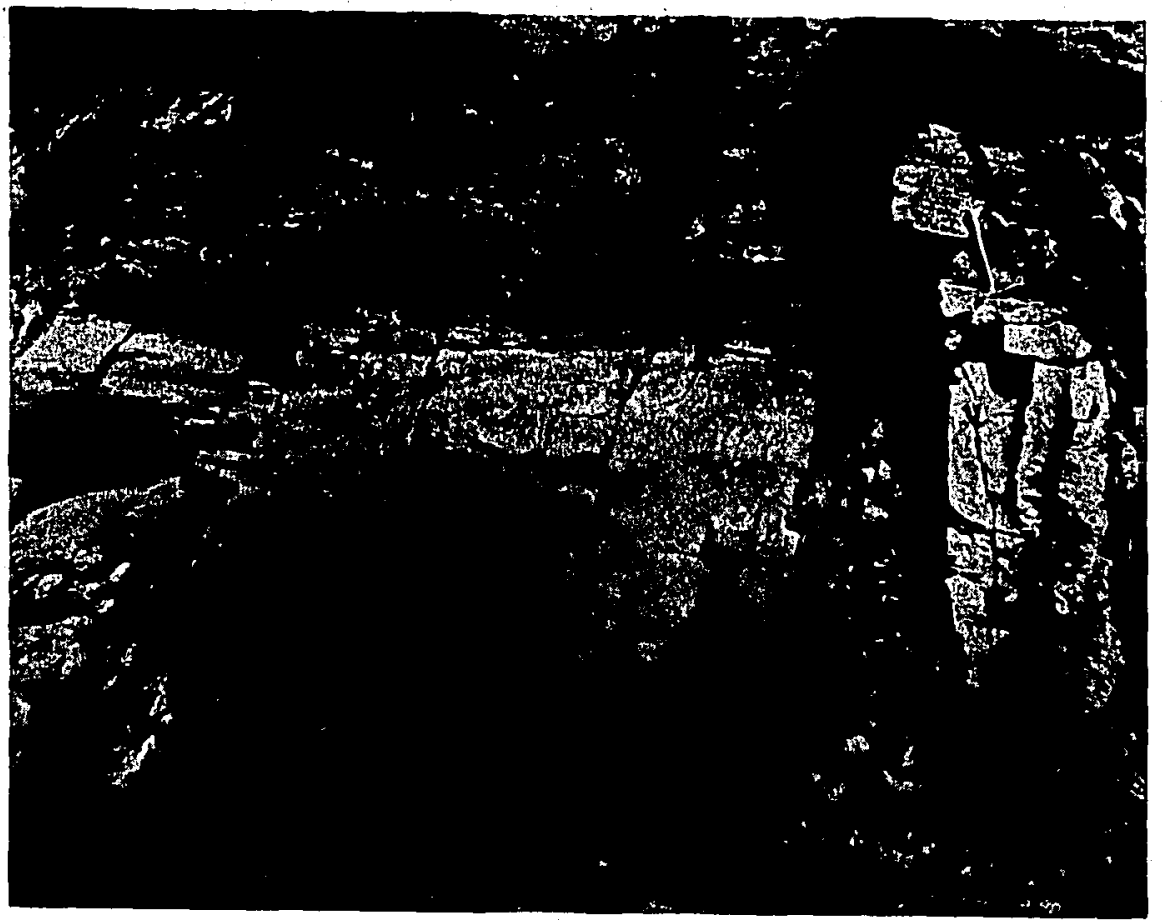

Fig. 1.-Ordovician seliments resting on eroded surface of massive grinite nenr Carysbrook. A thin line of conglomerate runs between the hat fund hummer.

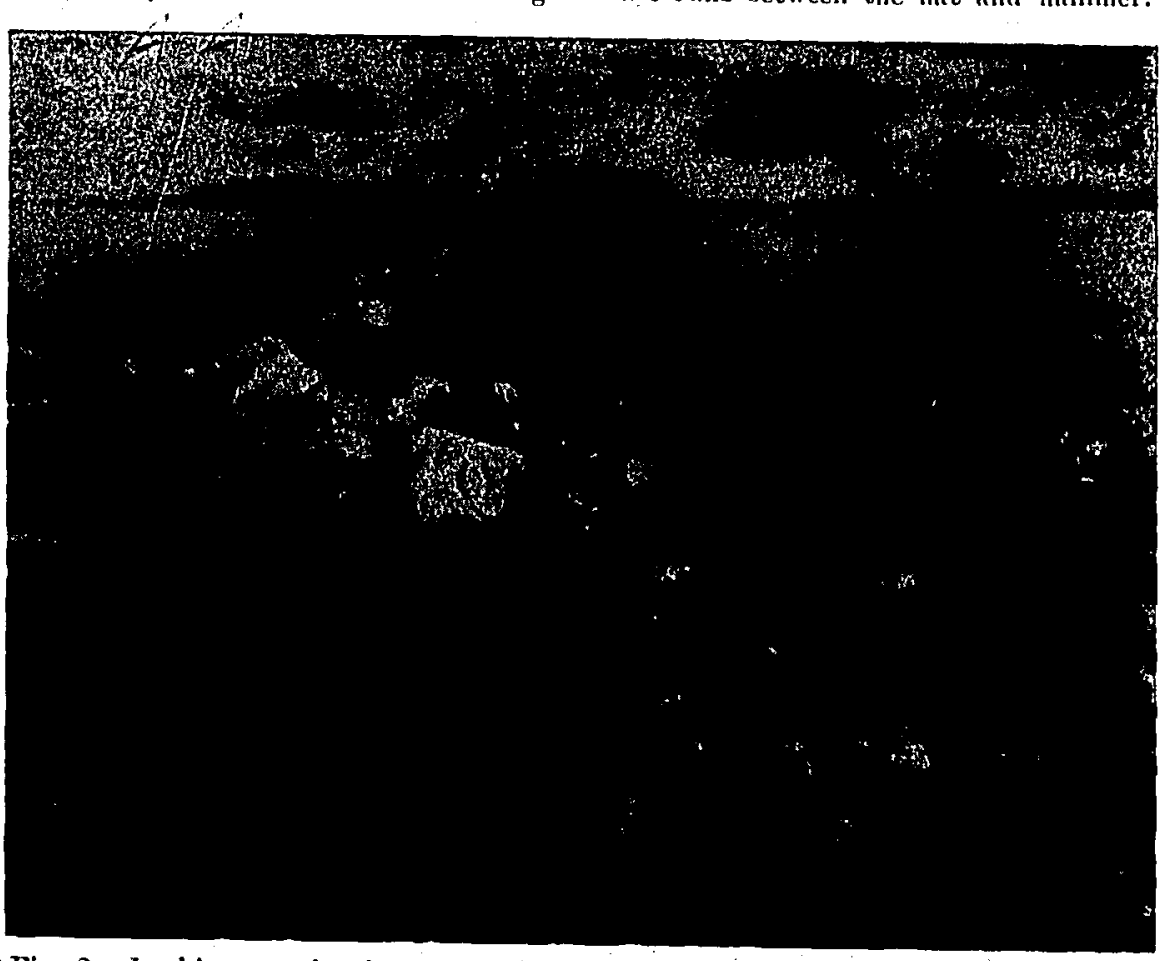

Fig. 2.-Looking north along summit of Willis Mountain. Piedmont peneplain iil bickground.

ORDOVICIAN SEDIMEN'S ON GRANITE, AND WILLIS MOUNTAIN. 


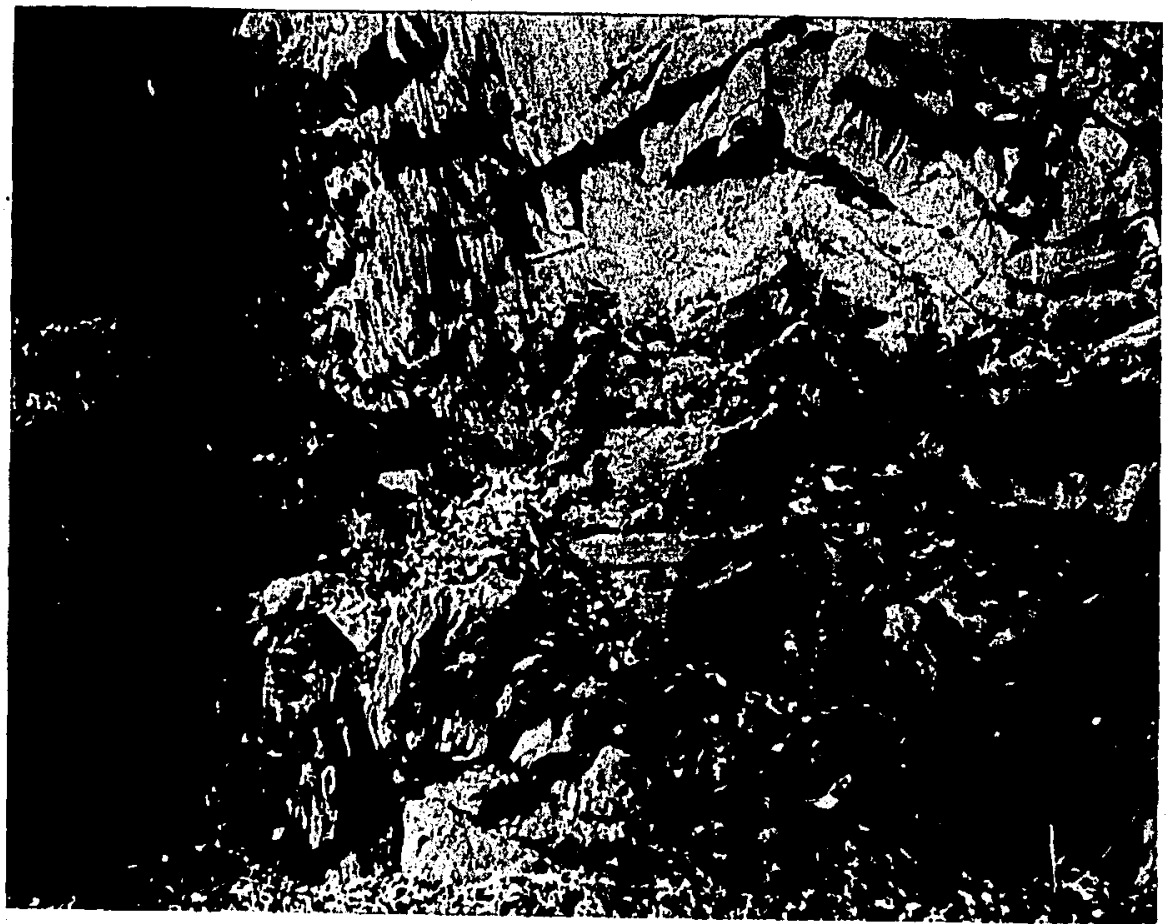

Fig. 1.-Beel of tuff in Ordovicinn slates. Blutis on the sonth side of Tnmes River.

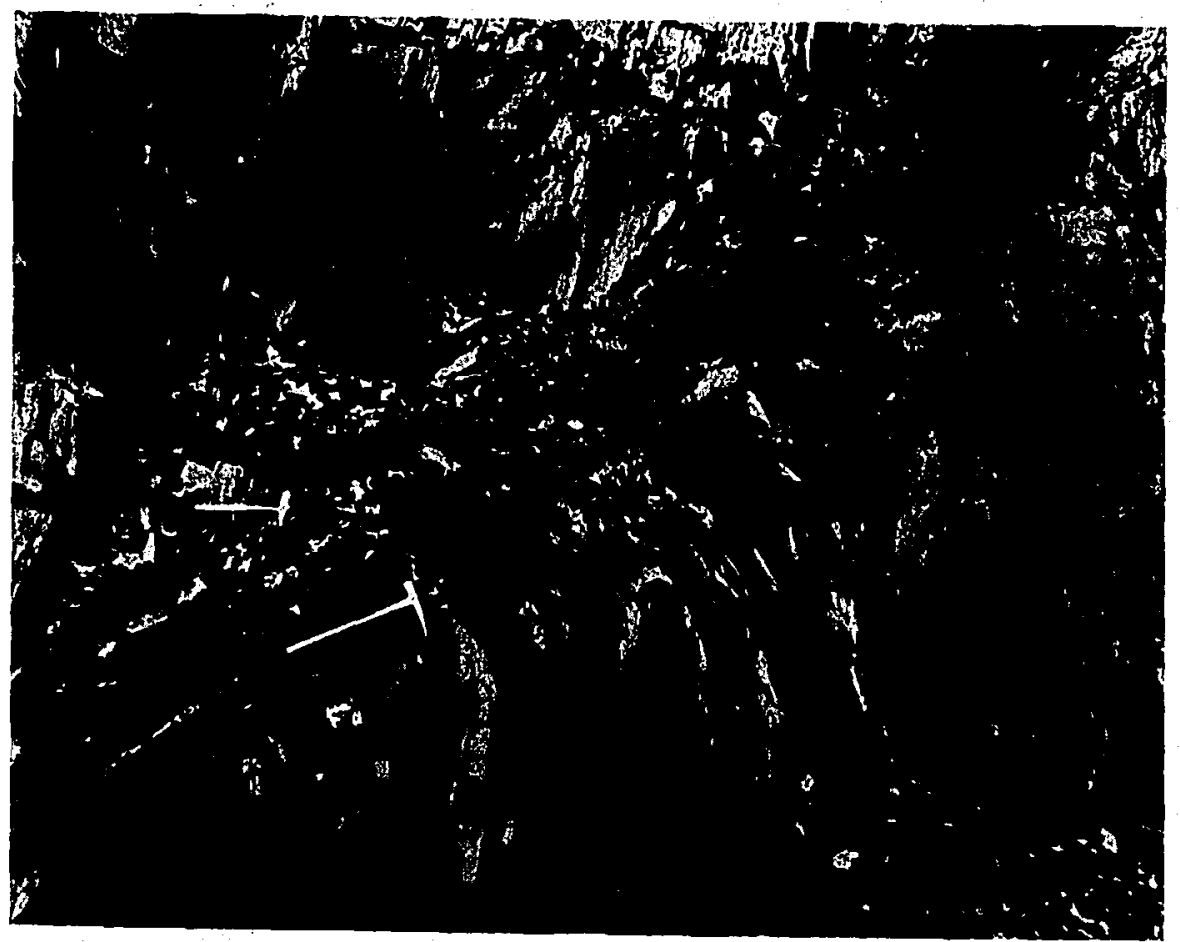

Fig. 2.-Fanlt in Ordovician slates. Blufts on south side of James River.

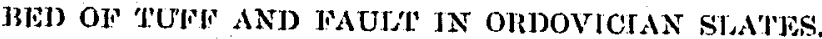


far from the conglomerate. The rock is clearly fragmental in origin and exhibits two directions of cleavage- one due to bedding, and the other to pressure-which intersect at an angle of about $40^{\circ}$. It is composed essentially of quartz, sericite, and chlorite, and contains occasional lenticular eyes of quartz 1 to $2 \mathrm{~mm}$. in diameter. Under the microscope (Spec. 'No. 1) ${ }^{a}$. the lenticular eyes are seen to be partly quartzite, and partly clear grains of quartz, some of which show evidence of enlarged borders. Liquid and gas inclusions, and a little zircon and titanite may also be identified. This rock is similar to the schist which occurs between the conglomerate and the quartzite about half a mile southeast of Penlan.

\section{Tuff.}

A bed of tuffaceous material is exposed in the bluff near the eastern border of the slate area and a mile west of Bremo bridge. It is interbedded witli black graphitic slates, which in places contain much pyrite. A photograph of the bed is shown in Pl. VII, fig. 1. Close to the hammer a nearly vertical fault can be seen, on the left of which the beds stand almost vertical, while on the right they are much contorted but nearly horizontal. The tuff is the light-colored material near the hammer. No other beds of tuff were identified in the area.

The tuff (Spec: 494) is a fine-grained, gray, slate-colored rock, distinctly fragmental to the naked eye, and very schistose, so that the fragments are drawn out in long streaks. Fine flakes of sericite, small grains of quartz, and a little pyrite are the only minerals distinguishable megascopically. Under the microscope it is seen to consist chiefly of fine-grained quartz, sericite, with numerous larger grains of quartz, averaging less than $0.5 \mathrm{~mm}$. in diameter, and occasional small phenocrysts of feldspar (orthoclase and acid plagioclase). Calcite is plentifully distributed through the section, and pyrite partly altered to limonite; occurs in small grains. Very fine, dust-like inclusions (graphite or iron oxide) are abundant throughout the slide. :

\section{Slate.}

GENEIAL GHARACTER AND DIBTRIBUTION.

Slate is the dominant rock of the Ordovician series of sedimentaries, and the beds probably have a thickness of more than 1,000 . feet, but because of the complicated folding and faulting only a rough estimate can be made. The areal distribution of the slate is coincident with that of the formation as a whole, for the thickness of the other members is insignificant in comparison with that of the slate.

uMicroscopic thin section made from specimen collected by Dr. T. P. Mayuard. 
The slate has a finely granular, crystalline texture, it is dark gray to black in color, and usually has a rather rough though very lustrous cleavage surface. It is graphitic and usually slightly magnetitic, contains a little pyrite, does not effervesce in cold dilute hydrochloric acid, and is very sonorous. The degree of cleavability varies greatly in different parts of the area, but is usually high, so that the slate can be split readily into slabs of any desired thickness.

In the vicinity of Arvonia the slate has been extensively quarried for roofing and other purposes, and at a number of places along the strike of the formation prospecting has been carried on with very encouraging results. Because of its highly crystalline character, the slate has great strength and durability, and some of it, used in roofing buildings orer a century ago, shows no discoloration from its long exposure. All of the slate in this area is not, however, available for commercial purposes, as the value of some of it is destroyed by close folding and faulting, and in a few localities the cleavage is not sufficiently developed.

\section{DETAILS OF OCOURRENCES.}

A detailed report on the slate deposits of Virginia is now in preparntion, and will be published shortly as Bulletin No. $X$ of the State Geological Survey; therefore the following descriptions will be brief, and for the most part limited to facts bearing on the structural relations of the slate formation.

Arvonia.-At Arvonia there are extensive quarries, all of which are located on the east side of the slate belt. In these openings the bedding and cleavage of the slate are identical, striking $\mathrm{N} .33^{\circ}$ to $37^{\circ} \mathrm{E}$. and dipping $70^{\circ}$ to $90^{\circ}$ southeast. There are three sets of joints, namely, vertical dip joints striking northwest; strike joints, running northeast and southwest and dipping $70^{\circ}$ to $80^{\circ}$ southeast; and diagonal joints some of which $\operatorname{dip} 30^{\circ}$ east while others dip $55^{\circ}$ west. Quartz veins are occasionally present, some of which contain calcite, and a little chlorite and biotite. In one of the quarries a dike of olivine diabase is exposed, which is 12 feet thick and traverses the slate diagonally.

The slate is very dark gray, with a faint greenish hue; it shows a distinctly granular crystalline texture to the naked eye; and has a highly lustrous cleavage surface, which is commonly rough or slightly wrinkled because of the presence of small flakes of biotite and of minute grains of the iron ores. According to Dale ${ }^{a}$ the mineral constituents, in the order

$a$ Dale, T. N., Slate Deposits and Slate Industry of the United States, Bull. U. S. Geol. Survey, No. 275, 1806, p. 114. 
of their relative abundance, are muscovite and sericite, quartz, biotite, carbonate, graphite (or carbonaceous matter), pyrite, chlorite, magnetite, with accessory plagioclase, zircon, hematite, tourmaline, and rutile.

The following microscopic description of the slate from the Williams quarries is given by Dale, and may be taken as representative of the other quarries in this vicinity:

"Under the microscope it shows a matrix of minute alternating beds, chiefly of fine muscovite, with coarser ones, chiefly of quartz, the former with. a brilliant aggregate polarization, the latter with a faint one. These beds are parallel to the cleavage. The quartz fragments measure up to $0.085 \mathrm{~mm}$. Scattered throughout both the more micaceous and the more quartzose becls are crystals, lenses, and particles of pyrite, numbering about 25 to each square millimeter and measuring up to $0.09 \mathrm{~mm}$., rarely 0.15 and 0.42 , with their longer axes parallel to the cleavage. These probably include a little magnetite. There are also biotite scales transverse to the cleavage, about 22 per square millimeter, ond measuring up to 0.12 , rarely $0.2 \mathrm{~mm}$. Almost, if not quite, as abundant are plates and rhombs of carbonate. There are occasional scales of chlorite interleaved with muscovite, a few grains of plagioclase feldspar $0.047 \mathrm{~mm}$., rarely one of zircon, some tourmaline prisms $0.014 \mathrm{~mm}$. long, much extremely fine graphitic (or carbonaceous?) material, a few particles of hematite, and some rutile needles. Sections parallel to the cleavage are unusually brilliant in polarized light, owing to the abundance of quartz, biotite, and

Bluffs along James River.-The slates exposed in the bluffs along the south side of James River show evidence of much close folding and faulting (see Pl. VII). Near the fault shown in Fig. 2, which is located close to the railroad, 500 yards south of the mouth of Slate River, the slate has two equally developed cleavages intersecting at an angle of about $5^{\circ}$. One of these is the ordinary slaty cleavage due to pressure, and the other is probably slip cleavage due to minute faulting. As the two cleavage surfaces reflect light at slightly different angles, the slate has a very striling appenrance. About a quarter of a mile farther east a similar slate is exposed, in which the angle between the two cleavages is $25^{\circ}$, but one is much better developed than the other. It is possible that one cleavage is due to bedding.

Some of the slates are highly graphitic, and in others pyrite is very plentiful, occurring in thin layers parallel to the bedding. Hematite is occasionally present in the form of thin plates, a fraction of a millimeter in diameter.

Carysbrook.-The slate exposed in the railroad cut half a mile south of Carysbrook is wholly lacking in slaty cleavage, but has a distinctly

aDale, T. N., Ibid., pp. 113-114. 
schistose structure parallel to the strike of the formation, which causes the rock to break in roughly prismatic shapes. This peculiarity is probably due to the location of the material at the bottom of a synclinal fold, where the pressure was approximately equal in all directions except along the axis of folding.

The strike of the formation is about N. $25^{\circ} \mathrm{E}$. and there are three principal sets of jointing, namely, nearly vertical strike joints running northeast and southwest; joints which dip about $30^{\circ}$ southeast and are approximately parallel to the contact with the underlying granite; and transverse joints having a strike of $\mathrm{N} .60^{\circ} \mathrm{W}$. and dip of $75^{\circ}$ northeast. The latter are spaced 2 to 8 inches apart.

The slate (Spec. 505) is dark gray, with little luster, and contains numerous flat discs of specular hematite, which are oriented in all directions parallel to the axis of folding. These plates vary in diameter up to $1 \mathrm{~mm}$. and in thickness up to $0.1 \mathrm{~mm}$.

Examined microscopically the chief constituents of the ground-mass are, in the order of their relative abundance, sericite, quartz, chlorite, with accessory tourmaline, and zircon. Some of the quartz occurs in lenticular eyes less than 0.5 millimeter in length, which occasionally contain small fragments of zircon. Prisms of greenish-brown tourmaline, ranging up to 0.2 millimeter in length, are fairly plentiful, and are usually oriented parallel to the schistosity. Some of the thin discs of hematite contain numerous small inclusions of quartz.

TRIASSIC.

The small area of sedimentary rocks shown on the map (Pl. I), between Ca Ira and Willis Mountain, belongs to the Triassic (Newark) system, and is the northern end of the Farmville area, which extends in a southwesterly direction for a distance of over 20 miles. In this northern portion the rocks consist of gently dipping beds of conglomerate, sandștone, and shale. They are deep red in color, and are in marked contrast to the surrounding crystalline rocks, chiefly granite and pegmatite, which weather to a light gray soil." Near Farmville fine, light-colored sandstones and shales occur interbedded with several smill coal seams, the lighter color being undoubtedly due to the reducing action of the carbonaceous matter.

The area as a whole is, topographically, a basin surrounded by hills of crystalline rocks, but lack of exposures make it difficult to work out the detailed geologic structure. The stratified rocks of the Triassic rest un- 
conformably on the metamorphosed pre-Cambrian sediments and the granites; and these underlying formations dip steeply toward the southeast. The Triassic beds are much disturbed, changing abruptly from northeast to southwest dips, and Russell determined the presence of at least four north and south faults. ${ }^{a}$ One of these faults forms the eastern border of the area about 2 miles north of Farmville, and there the stratified rocks are much broken and slickensided. In the absence of better exposures, it is impossible to measure the thickness of the beds, but everything indicates that they are of no great depth.

The rocks of the Triassic system have not undergone the great crustal movements which have so intensely metamorphosed the older rocks of the area; indeed, for the most part, they have not been thoroughly consolidated. Since these rocks have not extensive areal distribution in the region mapped, and since they are of no economic importance, they will not be discussed in this report.

\section{ROCKS IGNEOUS IN ORIGIN.}

GENERAL CLASSIFICATION.

The rocks of igneous origin described in this report are classified, in so far as possible, gccording to their relative age. The position of some of these rocks in the geological column is accurately lnown, that of others can be determined within comparatively narrow limits, and in a few instances there is considerable uncertainty. As in the case of the sedimentary rocks, the chief criterion used in distinguishing between the preCambrian and the later rocks is that of relative schistosity, while the position of others is determined by their relation to sedimentaries of known age. Under the description of each rock type, the evidence upon which its age classification is based is given in detail. The principal groups into which the igneous rocks have been divided are: (1) Pre-Cambrian, (2) pre-Cambrian and Cambrian, (3) Cambrian or post-Cambrian, and (4) Triassic.

PRE-CAMBRIAT.

\section{Greenstone Sohists.}

GENEHAL OHARAOTER AND DISTRIBUTION.

A large area of greenstone schists is present along the northwestern border of the map, given on Pl. I, and extends for several miles to the westward. The southeast contact between these schists and the other pre-Cambrian rocks crosses James River about 1,000 yards west of Strath-

aRussell, I. C., Correlation Papers. The Newark System. Bull. No. 85, U. S. Geol. Survey, 1802, pp. 88-89. 
more, and continues in a general southwesterly direction for an unknown distance; passing northeast the greenstone schists apparently pinch out in the vicinity of Palmyra. On Slate River, 500 yards west of Hunts Creek, Ordovician slates are apparently in contact with the greenstone schists for a short distance.

Chloritic schists are common in the region between Wilmington and Kent's Store, and occur at several other localities in the area mapped, but as these rocks are derived chiefly from the hornblende schists that are found associated with the granites, they will be desoribed under that heading.

The rocks in the large area of greenstone schists vary in texture from dense aphanitic varieties to those that are medium fine-grained, and in places porphyritic. They usually show a pronounced schistose structure but some of the coarser grained rocks, which have undergone less alteration, are more nearly massive. The color is always green, and varies in shade according to the relative amounts of chlorite and epidote present in the rock.

The mineral constituents present in these rocks are quartz, chlorite, epidote, amphibole, calcite, plagioclase, magnetite, pyrite, and in some instances small amounts of rutile, ilmenite, and titanite. Very rarely a little-chalcopyrite or malachite can be identified.

Quartz and usually calcite are present in the ground-mass of the rock and these minerals also frequently occur as eyes and veinlets. The feldspars, and part of the quartz and magnetite, are the chief primary minerals that remain unaltered. The feldspars are basic plagioclase, and frequently show Carlsbad as well as albite twinning. Chlorite is abundant in all of the rocks, occurring in fine-grained dark green scales. Epidote is most plentiful along fracture lines, and it also occurs in some of the veinlets.

Small slickensided surfaces are common throughout the rock; they run in various directions but are usually approximately parallel to the schistosity. They are probably to be explained by the volumetric expansion which has resulted from the alteration of the rock, with the formation of hydrous from anhydrous silicates.

Microscopic examination of a large number of thin sections of the greenstone schists, shows that they are derived from basic igneous rocks, but the alteration has been so extensive that in most cases it is impossible to determine their original character. The texture in a few localities suggests that part of the schists were formed from massive rocks of deepseated origin, but it is not improbable that they are largely derived from basic lava flows. 
AGE.

The intense regional metamorphism which has affected all of the older rocks, and the lack of suitable exposures along the contact, make it impossible to determine the relation of the greenstones to the other preCambrian schists. When the surrounding portions of the Piedmont province have been mapped in detail some light will probably be shed on this question, but at present it is not even possible to make a statement concerning the relative age of the two formations. At the London and Virginia mine (see pp. 185-186) a chloritic schist is interbedded with the quartz-sericite schists but it is different in appearance and has probably had a different origin. The greenstone schists are classified as pre-Cambrian in age because of their extensive metamorphism under dynamic conditions, and because of the presence of gold-bearing quartz veins believed to be Cambrian in age. They resemble the Catoctin schist of the Blue Ridge and may be contemporaneous in age.

\section{DETAILS OF OCCURRENCES.}

Slate River.-The bluffs along Slate River, west of the mouth of Hunts Creek, furnish some of the best exposures of greenstone schist that are to be found in the district, and this section will be described in detail. The contact between the Ordovician slates and the greenstone schists crosses Slate River about 500 yards west of Hunts Creek, but is not exposed. On. the south bank of the river just west of the contact there is a bold, clifflike outcrop of the schist.

The rock (Spec. 495) is dark green, fine-grained, even-granular, and not quite as schistose as in most localities. Quartz, chlorite, and a few small cubes of pyrite are the only minerals recognizable megascopically. Under the microscope the rock is seen to be composed of quartz, chlorite, plagiocase feldspar, calcite, talc, epidote, and a little fine-grained magnetite. The quartz grains are slightly larger than the other minerals, and are frequently arranged in irregular lines and flat lenses parallel to the schistosity. The feldspars are ragged in outline and show extensive alteration to the secondary minerals of which the rock is chiefly composed. The chlorite and other minerals are very fine-grained.

A few yards farther west the rock (Spec. 448) is slightly finer grained, more schistose, and contains occasional lenticular eyes of fine-grained white quartz 3 or $4 \mathrm{~mm}$. in diameter. Examined under the microscope the lenticular eyes are seen to consist of clear rounded, interlocking grains of quartz, which contain small gas- and liquid-filled cavities and numerous 
rutile needles. Basic plagioclase feldspars are present, some of which show fractures filled with a fine-grained ground-mass, consisting chiefly of chlorite. Calcite, epidote, and zoisite make up the remaining mineral constituents.

Greenstone schists, essentially similar to those just described, continue for several miles up the river with only a little variation here and there. In one place a peculiar veinlet (Spec. 449) about a quarter of an inch wide, was seen cutting the schist. It consists of dark green micaceous chlorite, with cleavage parallel to the walls, and phenocrysts of white feldspar, 3 to $4 \mathrm{~mm}$. long, which project out from the walls of the veinlet. ' The feldspars show twinning after both the Carlsbad and the albite laws. Nearly a mile west of the creek, a light green rock outcrops which is nearly massive in texture. It is medium coarse-grained, and is composed for the most part of light green hornblende and feldspar. The hornblencle is partly altered to chlorite. It is evidently an igneous rock (probably diorite), which has been only slightly altered.

At the Lightfoot mine, on the southeast side of Slate River, 2 miles northwest of Arvonia, the country rock is the typical greenstone schist found everywhere in this section. It is described in detail on pages $241-242$.

Lightfoot farm.-On the farm of P. W. Lightfoot, $13 / 4$ miles $N .15^{\circ} \mathrm{F}$. of Arvonia, an 18-foot shaft has been sunk in prospecting for copper. Most of the rock exposed on the dump is a fine-grained greenstone schist containing scattered crystals of pyrite, less than $0.5 \mathrm{~mm}$. in diameter, and much fine-grained magnetite. In places there are small segregated areas containing pyrite in coarse, irregular crystals associated with white quartz. A few pieces of rock were seen which contained partly altered phenocrysts of feldspar, $2 \mathrm{~cm}$. in length.

At several points in this vicinity a few small specks of malachite can be seen in the country rock. Pebbles of magnetite are found on the surface in places where they have weatherd out from the greenstone.

Anaconda mine.-The greenstone schist at the Anaconda mine, near Eldridge Mill, is described on page 244. About 400 yards northeast of the mine several small surface openings have been made in prospecting for asbestos. Some chlorite schist is exposed in these pits, but most of the rock is a light green talc which usually contains a few scattered needles of amphibole, probably actinolite. In places there are large masses of amphibole asbestos, part of the fiber being 7 to 8 inches in length, but much of it is cut by joint planes spaced about 2 inches apart. Masses, composed chiefly of actinolite in more or less radiating crystals, are present 
on the dump. Magnetite in small grains is scattered through both the chloritic and talcose schists.

Shores.-A quarry for railroad ballast is located on the Chesapeake and Ohio Railivay about three-quarters of a mile southeast of Shores. The rock exposed is dark green in color, fine-grained, and is cut by numerous small segregation veinlets consisting of white, fine-grained quartz, and a little calcite and dolomite. These veinlets do not have sharp, well-defined walls but pass by gradation into the schist. The minerals present in the rock, which can be identified megascopically, are quartz, chlorite, calcite, magnetite, and epidote. The greenstone schist extends westward beyond Shores.

Hughes mine.-The gold veins at the Hughes mine, which is located on the Virginia Air Line Railway, 2 miles northeast of Fork Union station, occur in an area of greenstone schist. Specimens of the wall rock from this mine are described in detail on pages 182-183.

Palmyra.-In the vicinity of Palmyra and northwest from the town a greenstone schist is exposed, and in places the chloritic schists enclose masses of talc and steatite which have been worked to a limited extent. It is reported that a little copper ore was found on the west side of Rivanna River opposite Palmyra, occurring in greenstone schist similar to that near the Lightfont mine.

\section{Quartz-Feldspar Porphyries.}

A series of quartz-feldspar porphyries are exposed along Rivanna River about a mile south of Palmyra. These rocks vary from light to dark gray in color and from fine- to medium-grained; they are usually porphyritic to the naked eye, containing feldspar phenocrysts and eyes of blue opalescent quartz; and they all exhibit varying degrees of schistosity. In thin section under the microscope they are seen to consist essentially of quartz, potash and soda-lime feldspars, and certain secondary minerals such as sericite, calcite, chlorite, and epidote. The eyes of quartz usually show strain shadows, more or less fracturing, and granulation; and they frequently contain rutile needles and gas- and liquid-filled cavities. The potash feldspars include both orthoclase and microcline, and these as well as the acid plagioclase are extensively altered with the production of the secondary minerals mentioned above. There is also a little microperthite in some of the rock. The minor accessories comprise magnetite, ilmenite partly altered to leucoxene, titanite, and pyrite.

Rocks similar to these porphyries were not found elsewhere in the area mapped. It is possible that they are genetically connected with the in- 
trusive granites, but no evidence in support of this supposition could be discovered. For the most part these porphyries are more schistose than the granites and therefore they are probably older.

\section{Rhyolites.}

GENERAL DESORIPTION AND AGE RELATIONS.

Rhyolites occur interbedded with schists and other rocks at several points near the western border of the area mapped, but they are of no importance as geologic formations. They are light gray, hard, densetextured rocks, and all show a schistose or slaty cleavage, which becomes more marked in the weathered specimens. Watson and Powell noted the occurrence of these rocks south of James River in the Arvonia slate belt and described similar ones in the Quantico slate belt, where they occur interbedded with the slates which are Ordovician in age. ${ }^{a}$. The rhyolites in the James River section may be contemporaneous with those in the Quantico belt, but the writer found no evidence to indicate that this is true. Because of their marked schistosity they are here described with the pre-Cambrian rocks, although it is possible that they are younger.

\section{DETAILS OF OCCURRENCES.}

Bremo Bluff.-On the south side of James River, about three-quarters of a mile west of Bremo bridge, there is an exposure of rhyolite, about 20 feet thick, which is interbedded with knotted schists. The rock is light gray, dense-textured, and in places contains elongated spots due to gas cavities or to some mineral which has undergone decomposition. It has a slaty cleavage, which, while scarcely noticeable in the fresher specimens, becomes very prominent in the weathered rock. Under the microscope (Spec. 493) the rock is distinctly schistose and is seen to be composed of quartz, feldspar, biotite, chlorite, black iron oxide, partly magnetite, sericite, zircon, tourmaline, titanite, and small areas of glass.

Slate River.-On the south side of Slate River about half a mile west of Hunts Creek there is a small outcrop of siliceous rock (Spec. 450), which is hard, close-textured, white in color, and very schistose. It is. probably a metamorphosed rhyolite. This rock occurs in the area of greenstone schists derived from basic igneous rocks.

Ballinger Creek.-About 13/4 miles east of Palmyra on the road to Wilmington, and 200 yards east of Ballinger Creek, there is an outcrop

aWatson, Thomas Lo, and Powell, S. L., Fossil Evidence of the Age of the Virginia Piedmont Slates, Amer. Jour. Sci., 1011, vol. xxxi, pp. 33.44. 
of rhyolite which is closely similnr to the rock found west of Bremo bridge. It is slightly more schistose in the hand specimen (485) and in thin section uncler the microscope it is seen to be porphyritic, containing phenocrysts of quartz and acid plagioclase feldspar about $0.25 \mathrm{~mm}$. in diameter. The quartz eyes contain gas- and liquid-filled cavities. The ground-mass is composed of quartz, feldspar, biotite, chlorite, and sericite.

Palmyra.-A short distance sonth of the railway station at Palmyra there is an outcrop of schistose rhyolite, in which small eyes of quartz can be distinguished by the naked eye. Exnmined in thin section (Spec. 14) ${ }^{a}$ under the microscope, small eyes of quartz and phenocrysts of orthoclase, $1 \mathrm{~mm}$. in length, which usually show Carlsbad twinning, can be seen in a fine-grained ground-mass, consisting of quartz, feldspar, magnetite, ilmenite partly altered to leucoxene, and a little chlorite and epidote.

PRE-CAMBRIAN AND CAMBRIAN.

Granites, Their Associated Pegmatites and Fornblende Schists. INTRODUOTORY STATEALENT.

The granites and their associated differentiates, occupying about twothirds of the area mapped, are confined to the eastern portion (sce Pl. I). Similar rocks continue beyond the limits of the map and extend eastward for an unknown distance, for below the falls at Richmond they are covered by the later sediments of the Coastal Plain.

These rocks, while for the most part closely related, belong to several periods of intrusion, and vary in character and mineral composition within comparatively short distances. In composition they range from true granites, in which potash feldspars are dominant over plagioclase, throngh granodiorites and quartz-diorites, to rocks that are composed almost exclusively of hornblende-every gradation between the two extremes being found. Quartz is always present, the more acid rocks contain muscovite, and biotite usually occurs in all except the most basic varieties, where it is completely replaced by hornblende. With the appenrance of hornblende in the rocks the potash feldspars disappear. The dominant rock type of the area corresponds to granodiorite or quartz-diorite in mineral composition. Pegmatites in places accompany the more acid facies, and pegmatitic quartz veins carrying a little mica are also present.

The large granite area occupying the eastern half of the map (see Pl. II) will be divided, for convenience in mapping and description, into

aThis thin section was made from a specimen collected by Dr. J. S. Grasty. 
4 separate divisions or belts, running in a northeast and southwest direction, in each of which the rocks exhibit certain peculiar characteristics. Passing from east to west these subdivisions are (1) the Cartersville aren, (2) the Elk Hill complex, (3) the pegmatite belt, and (4) the Columbia area. In addition to these there are several smaller areas which occur within the boundaries of the pre-Cambrian sedimentaries, namely, the Gold Hill area lying between Kent's Store and Tabscott, the Rosney area near the southern border of the map, and an area of unknown but limited extent, in which the only exposures are at the Greeley mine. Each of these areas is described in detail below.

\section{AGE.}

The granites are younger than the pre-Cambrian rocks with which they are in contrct, but the high degree of schistosity shown by most of the granites is proof of their solidification prior to the cessntion of the great crustal movements that preceded the Cambrian. Evidence that the period covered by the intrusion and solidification of the granites continued until after the close of these great movements, is furnished by the fact that the last of the granites to crystallize are practically massive in texture. Similar evidence is furnished by the lack of schistosity in many of the pegmatites and aplites, which are residual differentiates from the granite magma, and are therefore of later crystallization.

Granites crystallize under conditions of deep burial, and therefore much overlying material must be removed by erosion before they are exposed. Near Carysbrook, Ordovician sediments may be seen resting on the eroded surface of almost massive granite, and this indicates that a considerable time interval must have elapsed between the solidification of the youngest granite and the deposition of the sediments in Ordovician time.

A consideration of the facts outlined above leads to the conclusion that the intrusion of the granites probably began during the pre-Cambrian and continued into the early Cambrian. It is not unlikely that the crustal movements which terminated the pre-Cambrian, and the intrusion of the granites, are both manifestations of the same general forces.

\section{Cartersville Area.}

GENERAL DESORIPTION.'

The Cartersville area occupies the southeast corner of the map (Pl. II) and its northwestern boundary, passing between Elk Hill and Pemberton, extends in a general southwesterly direction approximately parallel to and 
just west of the ridge road leading from Cartersville to Cumberland. There are very few rock exposures in this area except in the vicinity of James River. The outcrops in the bluffs along James River and the occasional exposures found elsewhere indicate that the dominant rock is a fine-grained, light gray granite-gneiss, containing much muscovite and usually a little biotite. Pegmatites are common but the hornblende schists are extremely rare.

DETAILED DLSCHPTIONS,

Pemberlon.-On the north side of James River, three-quarters of a mile southenst of Pemberton, there is a large ontcrop of gneissic granite. The strike of the schistosity is nearly north and south and the dip about $45^{\circ}$ east. There are two varieties of rock exposed at this point; one (Spec. 27 ) is the light gray muscovite granite which forms the dominant rock type in the Cartersville area; and the other (Spec. 28), underlying the first, is a highly schistose reddish-brown rock.

Examined megnscopically, the light gray granite (Spec. 27) is finegrained and composed of white feldspars, quartz, muscovite in flakes ranging up to 2 or $3 \mathrm{~mm}$ : in diameter, a little biotite in small black specks, and rarely small pink garnets. Under the microscope orthoclase feldspar is seen to be dominant over the soda-lime feldspar (probably oligoclase), and no microcline seems to be present; the muscovite is apparently primary; and the biotite is dark brown in color, and strongly pleochroic. Fine hair-like needles of rutile are very plentiful, occurring in feldspar, quartz, and muscovite, but they seem to be most abundant in the feldspars.

The dark-colored gneiss (Spec. 28), which underlies the rock described above, contains' occasional lenticular eyes of feldspar and quartz. The rock has a peculiar reddish-brown (almost purple) color due to the presence of much fine-grained, brown biotite. In thin section under the microscope the soda-lime feldspars (probably oligoclase) are seen to be dominant, and there is only a little orthoclase and less microcline present. Some of the feldspars show zonal extinction. The biotite occurs in small light brown flakes and there is also some muscovite. Grains of ilmenite partly altered to leucoxene are common, and hair-like needles of rutile, sometimes.curved, are occasionally present, being more numerous in the potash feldspars. A little pyrite and a few small grains of titanite make up the remaining accessory minerals.

A mile northwest of Pemberton, the granite exposed is nearly white in color and almost free of biotite. The minerals recognizable in the hand specimen (25) are white feldspar, quartz, and muscovite, a very. 
little biotite, and occasionally small pink garnets. Under the microscope the rock is seen to consist of irregular individuals of feldspar, quartz, and muscovite, ranging up to $1 \mathrm{~mm}$. or over in diameter, which are surrounded by and grade into a finer ground-mass, composed largely of quartz and feldspar, and frequently granophyric in texture. Named in the order of their relative abundance, the mineral constituents are potash feldspar (chiefly microcline), quartz, soda-lime feldspar (probably oligoclase), muscovite, and a little biotite. The albite twinning in the plagioclase is very fine and sometimes absent. Around their border portions the feldspars frequently show graphic intergrowths with quartz. The muscovite is partly secondary after feldspar but most of it is probably primary. Only a little biotite is present, occurring in small dark brown flakes which are partly altered to chlorite. The quartz shows strain shadows and contains numerous fluid-filled cavities, some of which have moving bublules.

Cartersville.-Fresh rock is exposed at a number of places in the vicinity of Muddy Creek and along the road a mile south of Cartersville. Most of it is the light gray muscovite granite, similar to Spec. $2 \%$, described above. In the rond 200 yards southeast of Muddy Creek there is an outcrop of porphyritic granite. The rock (Spec. 473) contains numerous phenocrysts of white, unstriated feldspar ranging up to $1 \mathrm{~cm}$. in diameter, and in places these feldspars constitute the greater part of the rock mass. They are surrounded by a fine-grained ground-mass of feldspar, quartz, biotite, and muscovite. A similar rock occurs on the opposite side of the river, about halfway between Pemberton and Stokes, where the feldspar phenocrysts range up to 5 or $6 \mathrm{~cm}$. in diameter and are strung out in lines parallel to the schistosity. In some of the rock the large feldspars are so numerous that it resembles a pegmatite rather than a granite porphyry. The dominant rock in this vicinity, as elsewhere in the Cartersville area, is the light gray, muscovite granite. In places it contains pink garnets $0.5 \mathrm{~cm}$. in diameter. At several points the dominant rock is cut by dikes of later granite, 2 or 3 feet in thickness. This later granite is finegrained, less schistose, and contains more biotite and less muscovite.

Stolies.-One of the few places in the Cartesville area where hornblende rocks occur is located above three-quarters of a mile west of Stokes. At this point there is a small outcrop of fine-grained, even-granular schist, showing slightly gneissic banding, and composed essentially of quartz, feldspar, black hornblende, and epidote. The surrounding rock is chiefly a muscovite granite with occasional outcrops of pegmatite. 


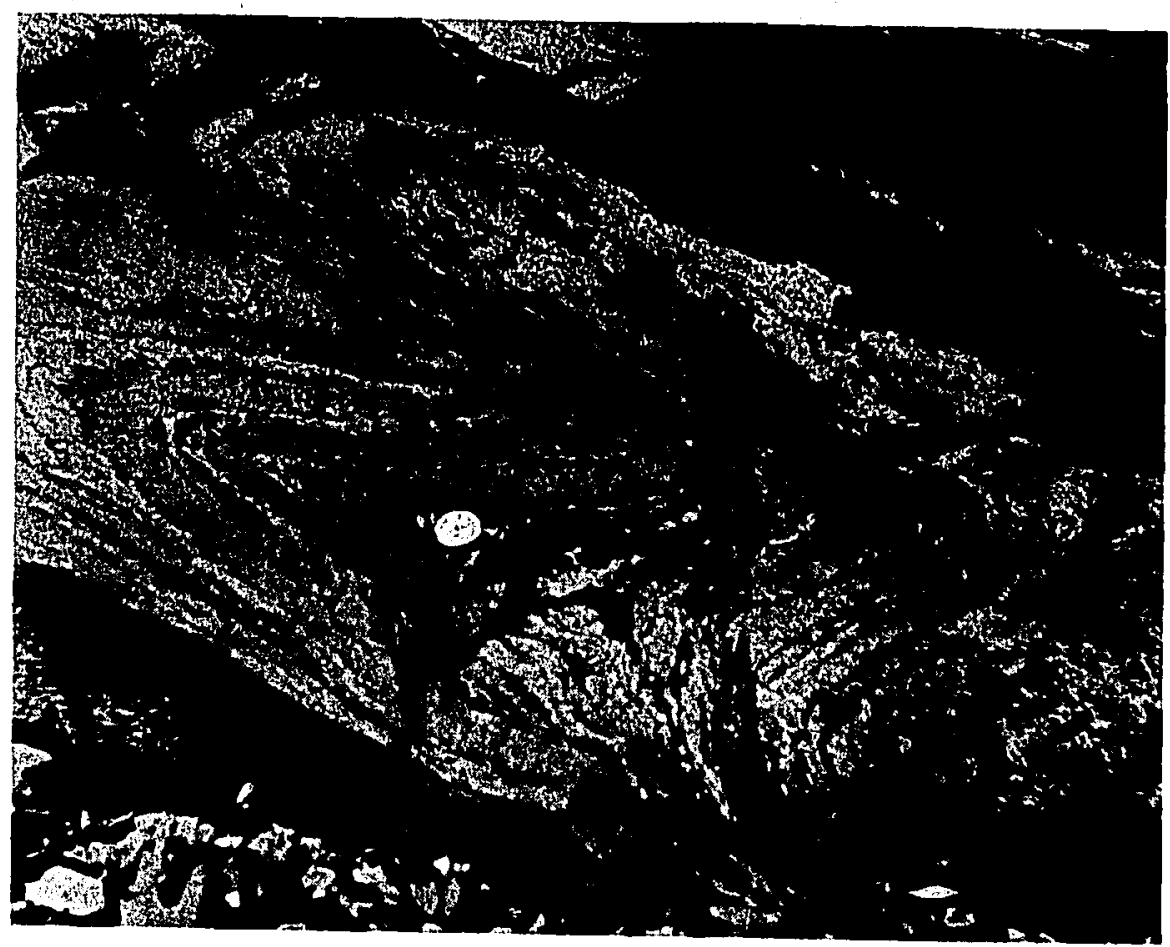
Fig. 1.- Flow structure in bunded gneiss intruded between lnyers of hormblende
sclist.

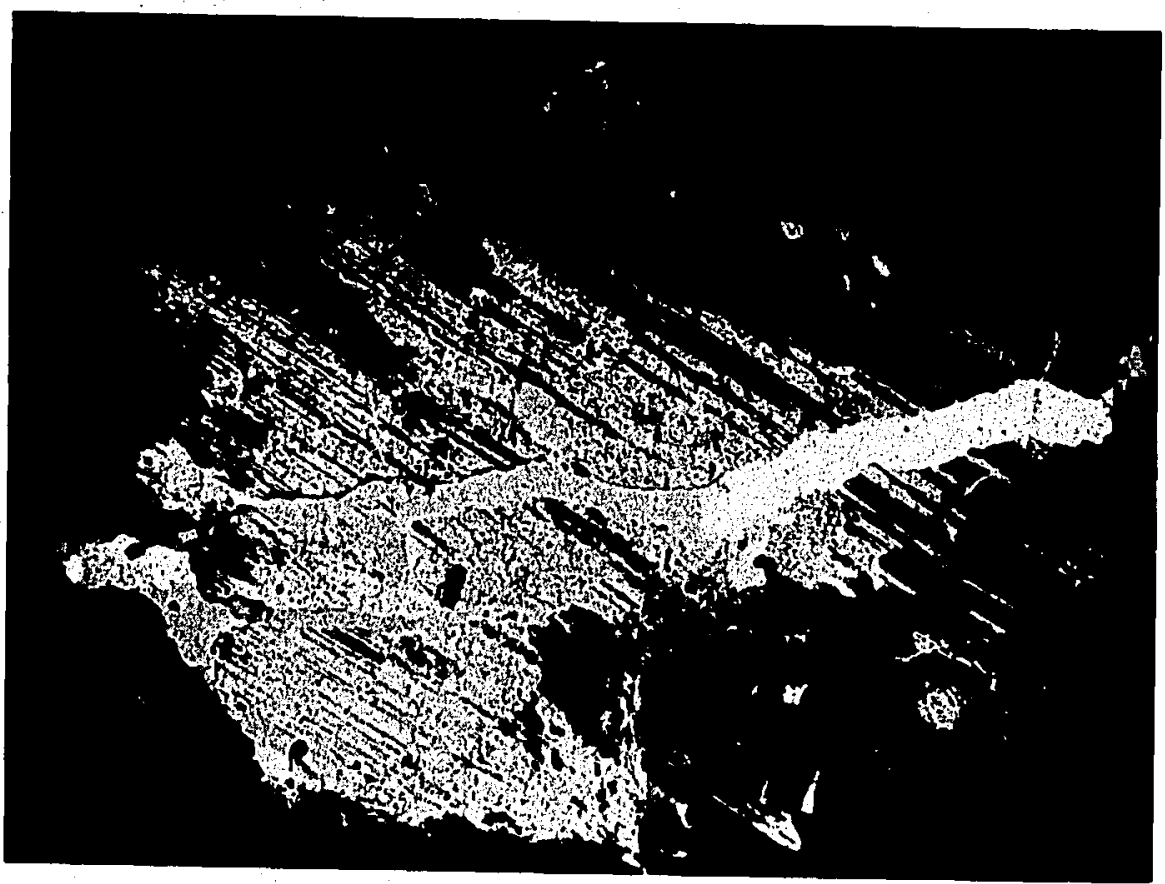

ligr. 2.-Photomicrograph of plugioclase feldspatr in vein quart\% from the Waller. mine. With analyzer. Ningnifled 27 diameters. See page 140. Speeinen
No. 217.

FIOIV STRUCTURE AND PIAGIOCLASE FEIDSPAR. 
Elk Hill Complex.

GENERAL DESORIPTION.

The Elk Hill complex is made up of three principal rock types-biotite granite, hornblende schist, and pegmatite-which occur interleaved in layers of varying thickness and in places are much contorted. The hornblendic rock appears to have been formed first and the granite intruded into it later, while the pegmatite frequently cuts both of the other rocks. The complex is from one to $11 / 2$ miles wide where it crosses James River at Elk Hill, and the best exposures are found in the bluffs three-quarters of a mile below Elk Hill. There are exposures along the road $11 / 2$ to 2 miles east of Flanagan Mills, and also in the road just southeast of Fife, but at neither of these localities is it possible to obtain fresh material.

DETAILED DESCRIPTIONS.

Excellent outcrops of fresh rock occur along the bluffs, three-quarters of a mile southeast of Elk Hill, where much blasting was done to make room for the old James River canal. In the photograph shown in Pl. VIII, fig. 1, the straight dark bands are hornblende schist, while the lightcolored layers consist of biotite granite and pegmatite. The contortions seen in the layer or dike of granite, which occupies the center of the photograph, probably represent flow structure, for if they were formed by crustal movements occurring after the complete solidification of the rock the layers of hornblende schist would likewise have been affected. The light-colored bands in the granite are pegmatitic in character. Elsewhere in the immediate vicinity the granite may be seen cutting across the hornblendic rock while the veinlets of pegmatite sometimes stop short at the contact and sometimes cut across both rocks.

The hornblende schist (Spec. 22) is dark gray to nearly black in color, and is composed of black hornblende, in crystals ranging up to 2 or 3 mm. in length, white feldspar, and a little black biotite. Small grains of pink garnet can be identified in places. The rock is cut by narrow, irregular veinlets of white feldspar and quartz, and contains lenticular eyes of feldspar $2 \mathrm{~cm}$. and less in diameter. Occasionally a little fine multiple twinning can be distinguished on these feldspars. Under the microscope the hornblende shows perfect cleavage and is pleochroic in shades of light green, greenish-blue, and brown. The feldspars are plagioclase (probably oligoclase) and sometimes show zonal growth; multiple twinning is very fine when present and is frequently absent. There is also 
present a little quartz, occasional ragged prisms of tourmaline, numerous rounded grains of titanite, and a little epidote. The thin section is crossed by several microscopic fractures, which branch in places and are filled chiefly with quartz and feldspar.

The granite (Specs. 21 and 23) is a light gray, fine-grained rock, composed essentially of white feldspar, quartz, and a little black biotite, while small pink garnets can be identified in places. It is cut by occasional, irregular, segregation stringers of pegmatitic feldspar and quartz. Fine multiple twinning can sometimes be distinguished on the feldspars. In thin sections under the microscope, soda-lime feldspar is seen to be dominant with the potash feldspars (orthoclase and microcline) present in variable amounts; there are granophyric intergrowths of feldspar and quartz; and both the feldspar and quartz show fracturing and optical distortion. Biotite occurs in small flakes dark green to brown in color, and a little sericite is present as an alteration product of feldspar. Ragged prisms of tourmaline, and occasionally irregular grains of titanite, magnetite, and pyrite make up the accessory minerals. The quartz grains contain numerous fluid inclusions.

In mineral composition this rock corresponds to a granodiorite and is closely similar to the granite (granodiorite) exposed in the quarry at Columbia, an-analysis of which is given on page 65 . The Elk Hill granite is finer grained and probably contains less quartz than the rock at Columbia.

Passing northeast toward Elk Hill the granite bands become broader, less contorted, and more uniform in composition; and there is much less hornblende schist present. Near Elk Hill the schistosity has a strike of N. $45^{\circ}$ E. and a dip of about $45^{\circ}$ southeast. The granite exposed near Byrd Creek is similar to that in the Columbia area on the west side of the pegmatite belt.

In places the hornblende schist contains much epidote, and about a mile southeast of Elk Hill some of the rock is composed almost exclusively of light green, granular epidote and white feldspar. In a thin section of this rock (Spec. 26), examined under the microscope, the epidote is largely in excess, occurring in irregular rounded grains, that look as though they might be primary. It is slightly pleochroic, changing from light yellowish-green to colorless. The feldspars are partly kaolinized but are probably all plagioclase. A little quartz and a few small grains of ilmenite, partly altered to leucoxene, make up the remaining minerals present. 
Pegmatite Belt.

GENERAL DESORIPTION.

The pegmatite belt can be traced across the area mapped, in a northeast and southwest direction, from Hadensville in Goochland County, to Cumberland, near the southern boundary-a distance of over 30 milesand it extends for an unknown distance beyond the limits of the map. In width the belt varies up to nearly three miles, and perhaps more, for lack of exposure makes it difficult to locate the exact boundaries except in a few localities.

While pegmatite is the dominant rock in this belt, there is also much interleaved granite, especially along the eastern side. North of James River, where the area was mapped in detail, the northwest contact of the pegmatite with the granite is sharply defined, but the other boundary is less definite, for the pegmatite apparently fingers out into the granite; and in many places the two rocks are so closely associated that it would be impossible to map them as separate units. In most of the specimens of granite obtained from the central portion of the pegmatite area, and examined microscopically, the potash feldspars are dominant over the soda-lime feldspars. Hornblende schists are practically absent; no outcrops were seen, and the few pieces of float found were near the border portions

The pegmatite area is one of low relief and there are few prominent outcrops. It seems to be less resistant to erosion than the granite, and this probably explains the. location of Little Byrd Creek, which, throughout almost its entire length, is confined to the pegmatite belt.

\section{DETAILED DESORIPTIONS.}

James River section.-The best rock exposures found in the pegmatite belt occur along the steep hills and bluffs that border the lowlands on the north side of James River. The railroad station at Island is nęar the center of the belt, which is here about 3 miles wide. The western boundary crosses the river midway between Columbia and Island, and is sharply defined; but the eastern boundary, which crosses the river near Byrd Creek, is less definite, for the pegmatite is more or less interleaved with biotite granite and the exposures are rather poor.

Near the western boundary of the pegmatite belt, 11/4 miles northwest of Island, there are outcrops of coarsely crystalline pegmatite (Spec. 12-A) composed of pink orthoclase feldspar, quartz, and a little muscovite. The 
feldspar, which is dominant, occurs in irregular individuals ranging up to 2 or 3 inches in diameter. 'The rock is slightly gneissic in structure, the strike of the schistosity being northeast and southwest and the dip nearly vertical.

In places the coarse pegmatite is interleaved with a fine-grained pegmatite or granite (Spec. 12), similar in composition, and highly schistose. Examined under the microscope it is seen to be granitic in texture with occasional fine micrographic intergrowths of quartz and feldspar. Microcline is the doninant minernl, orthoclase being also present, while quartz and acid plagioclase feldspars occur in lesser quantities. The feldspars frequently show perthitic intergrowths and are partly kaolinized; the quartz contains irregular fluid inclusions, which occasionally hold moving bubbles; and both minerals have been more or less fractured and show some optical distortion. The muscovite is partly if not entirely secondary after feldspar. Magnetite, ilmenite partly altered to leucoxene, and titanite make up the minor accessory minerals.

A coarse-grained, gneissic pegmatite, which outcrops half a mile west of Island, contains numerous red gnrnets, 1 to $2 \mathrm{~mm}$. in diameter; otherwise it is similar to the rock previously described. In the vicinity of Island there is much biotite granite intermixed with the pegmatite.

Little-Byyd Creeli.-For several hundred yards east of Little Byrd Creek, and about 21/2 miles northeast of Island, the road to Fife is crossed by alternating bands of pegmatite and granife, which vary in width from an inch up to several feet. The average strike is N. $45^{\circ}$ E. The pegmatite (Spec. 71) is composed of pink potash feldspar, in individuals ranging up to 3 inches in diameter, quartz, a little muscovite, and a few dark red garnets, some of which are over half an inch in diameter. In places a graphic intergrowth of quartz and feldspar may be distinguished. Farther east the bands are somewhat contorted.'

Where the large branch crosses the road, half a mile west of Little Byrd Creek, a dark brown, fine-grained granite is exposed. It is about 50 yards wide and has a strike of N. $45^{\circ}$ E. The rock (Spec. 70) is finegrained, even-granular, except for occasional phenocrysts of potash feldspar about $0.5 \mathrm{~cm}$. in diameter, and is only slightly schistose. Examined under the microscope it is seen to consist of potash feldspar (chiefly orthoclase), soda-lime feldspar, quartz, biotite, muscovite, a little light brown hornblende, a few scattered grains of magnetite or ilmenite, and occasional needle-like inclusions of rutile. The feldspar individuals, near their borders, frequently show granophyric intergrowths with quartz. The 
quartz grains contain numerous fluid inclusions, some of which hold rapidly moving bubbles. Both quartz and feldspar show fracturing and optical distortion. The muscovite is partly secondary after feldspar but some of it is probably primary.

Lantana.-The contact between the pegmatite and granite crosses the road to Bula, 11/8 miles southeast of Lantana. The outcrops are much weathered but in places graphic intergrowths of feldspar and quartz can be seen. The pegmatite weathers to a white soil which is readily distinguished from the gray, sandy soil of the granite and the dark red clay of the hornblende schist.

Bula.- On the east side of the pegmatite belt, in the vicinity of Bula, the boundary is not very definite, for the pegmatite splits up into dikes that are separated by areas of granite. One of these dikes is located about half a mile southeast of Bula, and can be traced in a northeast and southwest direction for a mile or more. This pegmatite (Spec. 77) contains a large amount of muscovite mica, and flakes 2 or 3 inches in diameter are sometimes found on the surface.

Shannon Hill.-The western boundary of the pegmatite belt crosses the Three Chop road about 21/2 miles southeast of Shannon Hill. There are practically no outcrops along this ridge road, but an exposure of partly decomposed pegmatite was found in a recently opened ditch. The rock is a beautiful example of graphic pegmatite, being composed almost exclusively of feldspar and quartz, and shows little if any schistosity.

Dickey farm.-On the farm of G. S. Dickey, 2 miles southeast of Cremona, there are several pits that were sunk in prospecting for gold. Natural exposures are few in this vicinity, but the country rock is partly a dark granite similar to Spec. 70, described on page 60 . In the pits a dark blue, close-textured, siliceous rock is exposed, which appears to have been formed by silicification of the country rock, for it contains fragments of the granite that are only partly replaced by silica. The rock is extensively brecciated and has been recemented by white vein quartz. There are numerous vugs lined with quartz crystals and many of the veinlets show crustification. The minerals sphalerite, pyrite, chalcopyrite, and galena, are present in small amounts and may be identified in places; and assays are reported to show traces of gold and silver. The ore minerals, at least in part, appear to be of later deposition than most of the quartz; in one specimen, sphalerite occurs filling a small cavity which is lined with quartz crystals. 
Other localities.-Pegmatite is exposed at many places in Cumberland County along the strike of the pegmatite belt, but outcrops of fresh rock are rnie, and all that were examined in detail show little variation from the occurrences described above. Pegmatite is exposed near Willis River, for a mile or two southwest of Flanagan Mills; it outcrops near Reynolds Creek, about 2 miles sontheast of Trenton Mills, and again between Tally and Oak Forest; and there are numerous exposures in the vicinity of Cumberland, and near the southern boundary of the area mapped.

\section{Columbia Area.}

GENERAL DESORIPTION.

The Columbia granite area is bounded on the northwest by the meta-morphosed sedimentaries, chiefly pre-Cambrian in age, and on the southeast by the pegmatite belt; but much of the granite that occurs interleaved with the pegmatite and in the Elk Fill complex appears to be similar in mineral composition to the typical granite of the Columbia area, and probably has a common origin.

In the Columbian area there is very little rock present corresponding in mineral composition to a true granite, in which orthoclase is dominant over the plagioclase feldspar. Almost everywhere soda-lime feldspars are in excess, and near the border portion of the rock and close to many of the areas of hornblende schist, the potash feldspars are entirely absent. Therefore the rock may more properly be called a granodiorite or quartzdiorite. Muscovite is not common; biotite is usually plentiful in the dominant and more acid facies of the rock, but in the southern portion of the area it is largely replaced by hornblende.

Hornblende schists are of frequent. occurrence in all portions of the area except in the north end of the tongue or embayment lying between Carysbrook and Wilmington; they become more plentiful near the contact with the old metamorphosed sedimentaries, where they commonly form a narrow belt separating the granite from the older rocks. In some places a gradation may be traced from granite into hornblende schist, but frequently the contact between the two is sharply defined. The areas of hornblende schist vary in size from a maximum of several square miles down to small masses; such as are usually called schlieren.

In passing northward from James River toward Carysbrook and Wilmington, there is a gradual but very noticeable change, both in the mineral composition and in the texture of the rock. While the exposures 
are by no means continuous, outcrops are fairly plentiful along the bluffs of Rivanna River, and nowhere is there any evidence of sudden change such as would be expected if there were rocks present belonging to different periods of intrusion.

South of James River, soda-lime feldspars greatly predominate over the potash feldspars, which are frequently absent; most of the rock is homblendic rather than biotitic; and the areas of hornblende schist are common. Passing northward toward Carysbrook the potash feldspars become more abundant though they are usually subordinate to the plagioclase; hornblende is rarely present in the granite, while biotite which is plentiful near the river becomes relatively scarce; and no areas of hornblende schist were found northwest of Rivanna Mills. The change is therefore one of decreasing basicity, and of decreasing percentages of the minerals that commonly crystallize out first.

In the vicinity of James River the granites are even-granular in texture but passing northward they become porphyritic and contain phenocrysts of feldspar. These phenocrysts are frequently bent and broken, the fractures as well as the interstitial spaces being filled with minerals of later crystallization; and this indicates that differential movements took place in the magma after crystallization had commenced and before the rock had completely solidified. The occurrence of masses of coarsegrained granite surrounded by rock of finer texture, such as may be seen in the quarry a mile northwest of Carysbrook (see description, pages 75-77), is probably due to the same causes.

The granite south of James River is highly schistose; the rocks exposed in the vicinity of Fork Union and Rivanna Mills are much less affected, while north of Carysbrook the granite is almost massive.

Pegmatite dikes are plentiful near Rivanna Mills, but were not noted elsewhere in the Columbia area. These pegmatites show little or no evidence of schistosity.

- All of the facts outlined above lead to the same conclusions, namely, that the granite in the north end of the embayment between Carysbrook and Wilmington solidified later than the rock in the remainder of the area; that important differential movements took place while this later granite was in process of crystallizing; and that the magma from which the latter solidified was probably residual from the crystallization of the older rocks. 
DETAILED DESCRIPTIONS.

Columbia. -The Cowherd quarries, ${ }^{a}$ located on the north side of James River at Columbia, and lying partly in Goochland County and partly in Fluvanna County, furnish the best exposures of fresh granite that are to be found in the Columbia area. These quarries were first opened when the James River canal was in service, but in recent years little work has been carried on, and since 1900 all operations have been suspended.

The rock is of medium dark-gray color, fine-grained, even-granular, and very schistose, with fine, straight banding. The minerals distinguishable megascopically are white, glassy quartz and feldspar, black biotite, a few, light green grains of epidote, which are for the most part closely associated with the biotite, and occasional small pink garnets. Multiple twinning can be distinguished on some of the feldspars with the aid of a pocket lens.

The strike of the schistosity is N. $45^{\circ} \mathrm{E}$. The vertical joints are widely spaced, intersecting the rock in three or more directions, and the joints parallel to the surface are spaced 2 to 3 feet apart in some of the deeper exposures. The granite is cut by numerous quartz veins which usually carry a little biotite. They vary from a fraction of an inch up to 2 feet in width, and run in all directions, though most of them are probably parallel to the schistosity. The fact that fractures frequently intersect the veins in directions coincident with the schistosity indicates that they were formed before the cessation of the period of deformation. ${ }^{b}$ The presence of biotite and, occasionally, of a little muscovite and feldspar, are additional evidence of the early formations of the veinlets and of their probable magmatic origin.

Examined in thin section (Spec. 240) under the microscope the rock is seen to be composed of the following minerals, the order given being that of relative abundance-quartz, soda-lime feldspar (oligoclase), potash feldspars (chiefly microcline), biotite, muscovite, epidote, garnet, calcite, zircon, and apatite. Under low magnification the schistosity is distinct; most of the mica shows parallel orientation and the segregation of the quartz into bands is so pronounced that in places they resemble veinlets. This fact suggests that some of the quartz veinlets exposed in the quarry may have been formed by segregation through fractional crystallization during the solidification of the granite.

aWatson, Thomas L., Granites of the Southeastern Atlantic States, Bull. U. S. Geol. Survey, No. 426, 1010, pp. 112-113.

bWatson, Thomas L., Ibid., p. 113. 
The quartz is present in large clear individuals that in places show a slightly wavy extinction; liquid- and gas-filled cavities are common, occurring partly in irregular shapes, and partly in small oval or rounded forms that are arranged in long rows or plnnes.

The soda-lime feldspar, which is dominant over the potash feldspars, shows rather coarse twinning after the albite law; the potash feldspar is nearly all microcline and there is only a little orthoclase present. Granophyric intergrowths of feldspar and quartz are fairly plentiful.

Biotite occurs in small dark green flakes showing strong absorption, and the white mica present is partly if not entirely secondary after feldspar. The epidote is in small, irregular light green to colorless grains, which are more plentiful wherever the biotite is abundant and are absent in areas containing little biotite.

Small pink garnets are scattered through the thin section; they are frequently fractured and broken, and seldom show good crystal form. The small amount of calcite present is evidently secondary. Numerous small idiomorphic crystals of zircon, and occasional apatite needles, are present as inclusions in the quartz and feldspar.

In mineral composition the rock is intermediate between granite and quartz-diorite. In the quantitative system of classification of igneous rocks it falls in class 1 , order 3 , rang 3 , and subrang 4 . A complete chemical analysis made from an average sample of the granite exposed in the quarry is given below.

\section{Analysis of granite from Cowherd quarry, Columbia.}

(Dr. Roger C. Wells, analyst.)

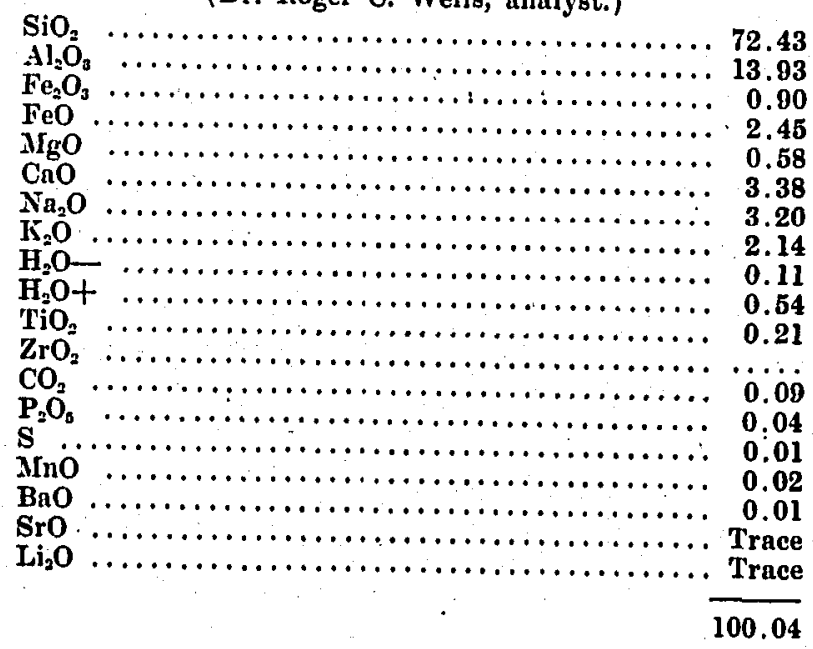


About a quarter of a mile northwest of the quarries described above, and on the east side of the Stage Junction road as it leaves Columbia, a fresh surface of granite is exposed by recent blasting. The rock is cut by irregular veinlets of quartz some of which contain biotite mica; and there are also veinlets of coarsely crystalline calcite ranging up to $\dot{2}$ inches in width.

Megascopically the rock (Spec. 5) is similar to the granite described above, excepting that the gneissic banding is slightly more prominent. Under the microscope the chief difference is in the relative proportion of the feldspars, orthoclase and microcline being present in very subordinate amounts. White mica is practically absent and there is a little hornblende present, dark green to bright blue in color. Ilmenite, partly altered to lencoxene, occurs as a minor accessory constituent.

Passing northward along the Stage Junction rond bands of hornblende schist begin to make their appearance at a distance of half a mile from Columbia. At first these bands or schlieren are only a few feet wide, but, as the contact with the sedimentaries is approached, they become larger and more plentiful until, within 400 or 500 yards of the contact, the granite completely disappears. There is also a change in the direction of the schistosity; near Columbia it has a strike of approximately $\mathbf{N} .45^{\circ} \mathrm{E}$., but near the sedimentaries the schistosity runs $N .15^{\circ} \mathrm{W}$., and appears to be parallel to the contact. These areas of hornblendic rocks occiur throughout most of the Columbia granite area, but they are much more plentiful in the vicinity of the borders.

About 11/4 miles east of Columbia there is a large rock exposure showing a gradation of the granite into hornblende schist. The schistosity varies from N. $20^{\circ}$ to $40^{\circ} \mathrm{E}$. The belt of hornblende schist is elongated parallel to the schistosity - the width being about 200 feet, and the length indeterminable because of the lack of sufficient expostires:

Specimen 6, taken more than 100 feet west of the belt of schist, is intermediate in character, but in the hand specimen is almost indistinguishable from the typical Columbia granite. The rock is dark gray in color, fine-grained, and shows a well-developed gneissic banding. It is composed essentially of quartz, feldspar, biotite, black hornblende, which is very difficult to distinguish megascopically from the biotite, small pink garnets, and a little epidote.

Examined under the microscope, soda-lime feldspar seems to be dominant over quartz, the potash feldspars are absent, and the hornblende is equal to or in excess of biotite. The feldspar frequently shows twinning 
according to the pericline as well as the albite law; the quartz contains numerous fluid inclusions arranged in long lines or planes; and the hornblende is brown to dark green in color, and shows occasional idiomorphic outlines with perfect cleavage. Small, well-formed, pink garnets, a few grains of light green to colorless epidote, and, rarely, small idiomorphic crystals of zircon make up the minor accessory minerals.

Specimen 7 was taken from the outcrop about 30 feet northeast of the rock just described. It is finer grained than specimen 6 , and contains more hornblende, much of which is concentrated in narrow streaks or schlieren. Under the microscope, plagioclase feldspar is seen to be dominant over quartz, and there is no potash feldspar or white mica present. The feldspars show twinning after the pericline as well as the albite law, and some of them contain peculiar inclusions of feldspar or quartz, which are present in alternate bands of the albite twinning. These inclusions are in the form of narrow parallel bands, which are oriented at an angle of $30^{\circ}$ to the twinning planes, and they all extinguish simultaneously. The hornblende is strongly pleochroic in shades of dark green, blue, and greenish-brown. The biotite is light brown to green in color and is not nearly so plentiful as the hornblende. Garnet in fairly well formed crystals, irregular grains of epidote, ilmenite, and small inclusions of zircon make up, the minor constituents.

About 110.feet east of the specimen just described, the rock (Spec. 8) contains flat, bladed crystals of black hornblende, ranging up to $1 \mathrm{~cm}$. in length, embedded in a medium-grained ground-mass of feldspar and quartz. With increase of hornblende there is a corresponding decrease of biotite, and portions of the rock are almost free of mica. The garnets are likewise larger in this rock, some of them being nearly $0.5 \mathrm{~cm}$. in diameter. The larger size of some of the minerals, especially the hornblende, may have been caused by a partial resolution before complete solidification had takn place, followed by continued crystal growth.

Microscopically, soda-lime feldspar is the dominant mineral and there is no potash feldspar or white mica present. Both albite and pericline twinning are common. Quartz is the second mineral in relative abundance and contains numerous irregular fluid-filled cavities. Dark green hornblende is the principal ferromagnesian mineral, only a little brown biotite being present. The remaining accessory minerals are garnet, in numerous well-formed crystals, ępidote, ilmenite partly altered to leucoxene, pyrite partly altered to limonite, and small included grains of titanite and zircon.

Specimen 9, taken from a point 30 feet southeast of the rock last described, is a typical quartz-diorite schist. It is a dark gray, medium- 
grained Jock in which black hornblende, and white quartz, and feldspar are the only minerals distinguishable megascopically. Under the microscope plagioclase (probably andesine) is seen to be dominant, but dark green hornblende is almost as abundant as the feldspar. Quartz, a little epiclote, and a few small, scattered grains of ilmenite make up the remaining constituents. Both quartz and feldspar show considerable optical distortion and some fracturing.

Specimen 10 was taken 80 feet farther northeast. Megascopically it is similar to specimen 9, but contains more hornblende and is darker colored, being almost black. Examined microscopically no feldspar could be distinguished. The minerals present in the order of their relative abundance are hornblende, quartz, epidote, chlorite, and a few scnttered grains of ilmenite.

About 100 feet to the east there is an outcrop of greenish-gray, talcose schist, which probably represents an alteration product of the amphibolite schist described above. In thin section (Spec. 11) under the microscope, the rock is seen to consist of needle-like crystals of secondary hornblende, light green to almost colorless talc, a little chlorite, and numerous small grains of magnetite.

Near the large creek 2 miles southwest of Columbia there is much quartz lying loose on the surface and these pieces contain much muscovite, and occasionally miarolitic cavities lined with poorly formed crystals of quartz, feldspar, and muscovite. Some of the mica shows well-developed hexagonal shapes.

On the road to Lantana, hornblende schists are first encountered about half a mile northeast of Columbia, and, continuing northeastward, the occurrences increase in number and extent, until in the vicinity of the contuct, little granite is to be found. The contacts between the arens of hornblende schist and the granite are commonly sharp and well defined, but in many places rocks occur that are intermediate in mineral composition.

Big Byrd Creek:-On the east side of Big Byrd Creek, near the contact between the granitic rocks and the altered sedimentaries, there is an outcrop of rock which is intermediate between the granite and the typical hornblende schists.

It is a dark gray, fine-grained gneiss (Spec. 29) composed essentially of feldspar; hornblende, quartz, and biotite. Examined microscopically the feldspar is seen to be all plagioclase; multiple twinning is frequently absent, and as the index of refraction is close to that of quartz, there- is 
difficulty in distinguishing between the two minerals. The hornblende crystals are strongly pleochroic, ragged in outline, and contain numerous inclusions of quartz, feldspar, and epidote. The biotite, which is partly altered to chlorite, is not plentiful. Ilmenite occurs in irregular grains scattered through the rock, and shows partial alteration to leucoxene.

Lantana.-A peculiar variety of the hornblende schist was found about $11 / 4$ miles southeast of Lantana. The minerals recognizable megascopically are black hornblende and a little fine-grained, white feldspar. The hornblende crystals are frequently stained a deep red color, and the contrast between the black, red, and white gives the rock a very striking appearance in the hand specimen (93). Examined microscopically it is seen to consist of hornblende, basic plagioclase, epidote, quartz, magnetite partly altered to limonite, and a few small grains of rutile.

About $21 / 2$ miles northeast of Lantana the pegmatite belt approaches within less than 400 yards of the altered sedimentaries, and the intervening space is largely occupied by hornblende schists. At this point the biotite granite is absent, being replaced by a hornblende-bearing rock (Spec. 99), which closely resembles a granite in appearance, but contains no potash feldspar. It is a medium, dark gray, gneissic rock, composed of. quartz, acid plagioclase, hornblende, and garnet, with. lesser amounts of magnetite, ziicon, and titanite. Some of the feldspar is unstriated and difficult to disfinguish microscopically from quartz, which it resembles in refraction and birefringence. The hornblende is dark green to bluish-green in color, strongly pleochroic, and shows fairly good cleavage. Pink garnets are very plentiful, and the larger ones contain numerous inclusions of quartz and magnetite.

Passing northeast from the locality just described, the lack of exposures makes it difficult to trace the exact contact between the granite area and the metamorphosed sedimentaries; and this difficulty is increased by the uncertainty as to the igneous or sedimentary origin of some of the rocks in the immediate vicinity of the contact.

Granite is exposed in the branch near the private road, less than a mile northeast of the Young American mine. It is a light gray, finegrained rock (Spec. 105), composed chiefly of quartz and feldspar, with minor amounts of biotite. Under the microscope the feldspar is seen to be plagioclase (probably andesine), but, as much of it is unstriated, it is distinguishable from quartz with difficulty. The rock contains a little sericite, ilmenite partly altered to leucoxene, and occasional small inclusions of rutile, titanite, and zircon. 
Tabscott.-Granite and hornblende schist outcrop together near the branch half a mile northeast of the locality last described and about $13 / 4$ miles south of Tabscott. The granite (Spec. 108) is a light gray, finegrained rock, gneissic in structure, and composed for the most part of quartz, feldspar, and small flakes of light green chlorite. Examined microscopically the feldspars are seen to be chiefly acid plagioclase, with only a little orthoclase present; granophyric intergrowths. with quartz are common; and in places the feldspars show alteration to sericite. Ilmenite occurs in small grains that usually show alteration to titanite or leucoxene. The alteration to titanite is more common and there are many grains of the latter scattered through the rock.

The hornblende schist (Spec. 109) is dark bluish-gray in color, and usually fine-grained. The hornblende, which is dominant, occurs in slender, prismatic crystals, that are dark green in thin sections, and frequently show idiomorphic outlines and perfect cleavage. Quartz and unstriated plagioclase feldspar (probably andesine) fill the interstices between the hornblendes. Ilmenite and rutile are prominent accessory constituents, occurring as included grains in all of the other minerals, though they are not so plentiful in the hornblende. There are also numerous grains of titanite present, probably secondary after the other titanium minerals, and small crystals of zircon occur as inclusions in the quartz.

A similar, but slightly coarser-grained, hornblende schist outcrops in the road 11/2 miles southwest of Tabscott. The rock (Spec. 215) is composed of hornblende, quartz, unstriated plagioclase (oligoclase or andesine), a little epidote, and numerous grains of titanite, some of which contain small inclusions of rutile. In these schists the hornblende crystals have a strong tendency to lie with their columnar directions almost parallel, and it is this that gives the rook its schistosity. The strike of the schistosity is N. $51^{\circ} \mathrm{E}$.

Payne farm.-On the Payne farm, 11/2 miles southeast of Tabscott, there is a number of old pits or quarries from which the Indians obtained steatite. These openings are surrounded by pieces of broken bowls which were ruined in the process of making. Recently, sawed slabs of this rock have been used to line the fire boxes of boilers, at some of the mines in the vicinity, and it is said to have proved very satisfactory for the purpose.

The rock (Spec. 107) is greenish-gray in color and in places contains small crystals of magnetite and pyrite. Under the microscope it is seen to consist largely of talc and needle-like crystals of secondary hornblende. There are also a few fragments of unaltered hornblende which may be primary, 
much chlorite, and a little magnetite or ilmenite, and titanite. 'The rock is evidently derived from a basic igneous rock, probably from the hornblende schists. A similar occurrence is described on page 68 .

Some of the rock in this vicinity contains a greater percentage of hornblende than the specimen described above, and other pieces were found that consist exclusively of bright green cleavable chlorite.

Trent farm.-On the south side of James River, in the southern portion of the Columbia area, the rocks are apparently more basic in composition, potash feldspars are practically absent and hornblende is often more prominent than biotite. On the farm of $\mathrm{S}$. W. Trent, 3 miles southwest of. Hatcher, homblende schist occurs in the vicinity of the contact. The rock is dark gray to black in color, with a highly lustrous fracture, due to the presence of much hornblende having approximately parallel orientation. 'The minerals present, in the order of their relative abundance, are prismatic hornblende, feldspar; quartz, and a little epidote. The feldspar is all plagioclase, corresponding to labradorite in extinction angle and index of refraction, and much of it is unstriated.

Passing northwest as far as Hatcher, hornblende is a prominent constitnent in most of the rocks found; in places it is dominant over the other minerals, forming the typical hornblende schists, but elsewhere feldspary do doininant, and the rocks correspond to diorites and quart\%diorites in composition. On the whole hornblende appears to decrease in abundance with distance from the contact. The same statement holds true for the rocks that are exposed between Lawford and the contact.

Trenton Mills.-On the west side of Willis River, in the vicinity of 'Trenton Mills, there is a large area of hormblende schist, possibly 2 or 3 square miles in extent. The rock is medium-grained and highly schistose, the color varying from gray to black according to the amount of feldspar and quartz present. The darker varieties are composed almost exclusively of hornblende.

New Canton.-In some of the branches 3 or 4 miles south of New Canton a hornblende granite or quartz diorite is exposed, which contains a few large flakes of dark brown biotite and small pink garnets. A short distance east of the county road and $13 / 4$ miles south of New Canton a light gray, gneissic rock (Spec. 300) is exposed which consists essentially of feldspar, quartz, biotite, and muscovite.

Examined under the microscope no potash feldspar could be identified. The plagioclase has an index of refraction slightly below quartz, approximately corresponding to oligoclase in composition, and frequently shows 
twinning after the albite and pericline laws, but much of it is unstriated. The biotite is brown to green in color and the muscovite is partly if not entirely secondary in origin. A little chlorite and epidote are present, but other accessories are rare.

Stearnes.-Near the Chesapeake and Ohio Railroad, 2 miles northenst of Stearnes and 4 miles southwest of Columbia, the granite (Spec. 14) is light gray, fine-grained, and shows distinct gneissic banding. Occasional phenocrysts of feldspar showing Carlsbad twinning can be distinguished in the hand specimen. This is one of the few localities in the Columbia area where the rock is a true granite in mineral composition. The minerals present, in the order of their relative abundance, are potash feldspar (chiefly microcline), soda-lime feldspar (oligoclase), and quartz; a little biotite, muscovite, calcite, and epidote; and lesser amounts of garnet, titanite, ilmenite, leucoxene, and zircon.

Microcline showing beautiful crossed twinning is the dominant mineral and orthoclase seems to be practically absent. Oligoclase, which is the second mineral in relative abundance, shows occasional twinning after the pericline as well as the albite law, and microperthite is fairly plentiful. Micrographic intergrowths with quartz are common. 'The biotite is dark green to brown in color and not very abundant; the flakes are usually oriented parallel to the schistosity of the rock. The white mica appenrs to be entirely secondary after feldspar, but there may be some primary muscovite present. It does not show the same uniformity of orientation that is exhibited by the biotite. Calcite is unusually abundant and is probably secondary after plagioclase. Epidote occurs in small grains, being more plentiful where the biotite is most abundant, and is undoubtedly secondary in origin. The garnets contain numerous small inclusions of quartz. Titanite is common and in places contains included grains of ilmenite, from which it may have been' derived. The ilmenite grain: occasionally show partial alteration to leucoxene.

For a mile northeast of Stearnes hornblende schist is exposed in the bluffs along the railroad. It is a fine-grained, dark bluish-gray rock, composed of small black prismatic crystals of hornblende, showing approximate parallel orientation, and white plagioclase and quartz. The contact with the granite on the northwest side of the schist is well exposed. It is sharply defined, without evidence of gradation, and has a strike of N. $45^{\circ} \mathrm{E}$.

Near Stearnes the hornblende schist is cut by narrow bands of siliceous rock 2 to 3 inches in thickness. This rock (Spec. 16) is fine-grained; 
light gray in color, and closely resembles a quartzite in texture and appearance. Small pink garnets and needles of dark green hornblende are present in places, and some of the rock contains much fine-grained magnetite. A thin section examined under the microscope contains irregular rounded grains of quartz, many idiomorphic crystals of magnetite, a few scattered prisms of dark green hornblende showing occasional crystal outlines, a little plagioclase feldspar, sericite, and small inclusions of titanite and zircon. The quartz contains numerous fluid inclusions.

Fork Union.-The contact between the granite and the metamorphosed, pre-Cambrian sedimentaries passes through the town of Fork Union. Granite is exposed in the road about half a mile southenst of the town. It is a medium-grained, light gray rock, containing flakes of biotite 2 to 3 $\mathrm{mm}$. in diameter, and is much less schistose than the rocks previously
described.

Examined in thin section (Spec. 50) ${ }^{a}$ under the microscope, potash feldspar (chiefly microcline) appenrs to be dominant over soda-lime feldspar, but the rock is so badly altered that it is impossible to determine their relative proportions. Micrographic intergrowths with quartz are common. Both quartz and feldspar show fracturing and strain shadows. The biotite occurs in greenish-brown flakes showing strong absorption. The feldspars and biotite are extensively altered with the production of epidote, a little chlorite, and some sericite, as the principal secondary minerals. Reddish-brown prisms of tourmaline $1.5 \mathrm{~mm}$. or more in length are occasionally present, and rutile needles are abundant especially in some of the biotite. Fluid inclusions are common in the quartz grains.

A similar granite, occurring at the Snead mine a mile north of Fork Union, is described on page 181 .

Rivanna Mills.-On the farm of H. Williams, half a mile north of Rivanna Mills, granite was formerly quarried to furnish stone for the dam and canal locks. This rock is medium dark gray in color and porphyritic in texture, containing eyes of feldspar that range up to nearly $1 \mathrm{~cm}$. in diameter. The minerals recognizable megascopically are feldspar, quartz, biotite, a little muscovite, and, rarely, small grains of pyrite. Some of the feldspar phenocrysts show fine multiple twinning. The schistosity is well developed, but is not nearly.so pronounced as in the granites exposed in the section along James River.

aThis thin section was made from a specimen collected by Dr. T. P. Maynard. 
An average sample of partly decomposed granite, from an outcrop 100 yards east of $\mathrm{Mr}$. Williams' house, upon assaying yielded 0.015 ounces of gold per ton (see pp. 220-221). The sample was taken after several inches of the partly decomposed rock had been removed in order to prevent contamination.

Dikes of pegmatite and aplite occur cutting the granite at several points on the Williams farm, and these rocks show very little if any evidence of schistosity. One of these dikes, located about 600 yards northeast of the house, is exposed in a prospect shaft 15 feet in deptl. It has a strike of $N .15^{\circ} \mathrm{E}$. and dips northwest at an angle of $45^{\circ}$. The pegmatite near the walls of the dike (see fig. 3) is fine-grained, and composed for the most part of feldspar and quartz, with only a little muscovite. The central portion of the dike consists chiefly of quart/ carrying more or less feldspar and containing occasional coarse crystals of pyrite. Picked specimens of this quartz are said to have assayed nearly $\$ 3.00$ gold per ton.

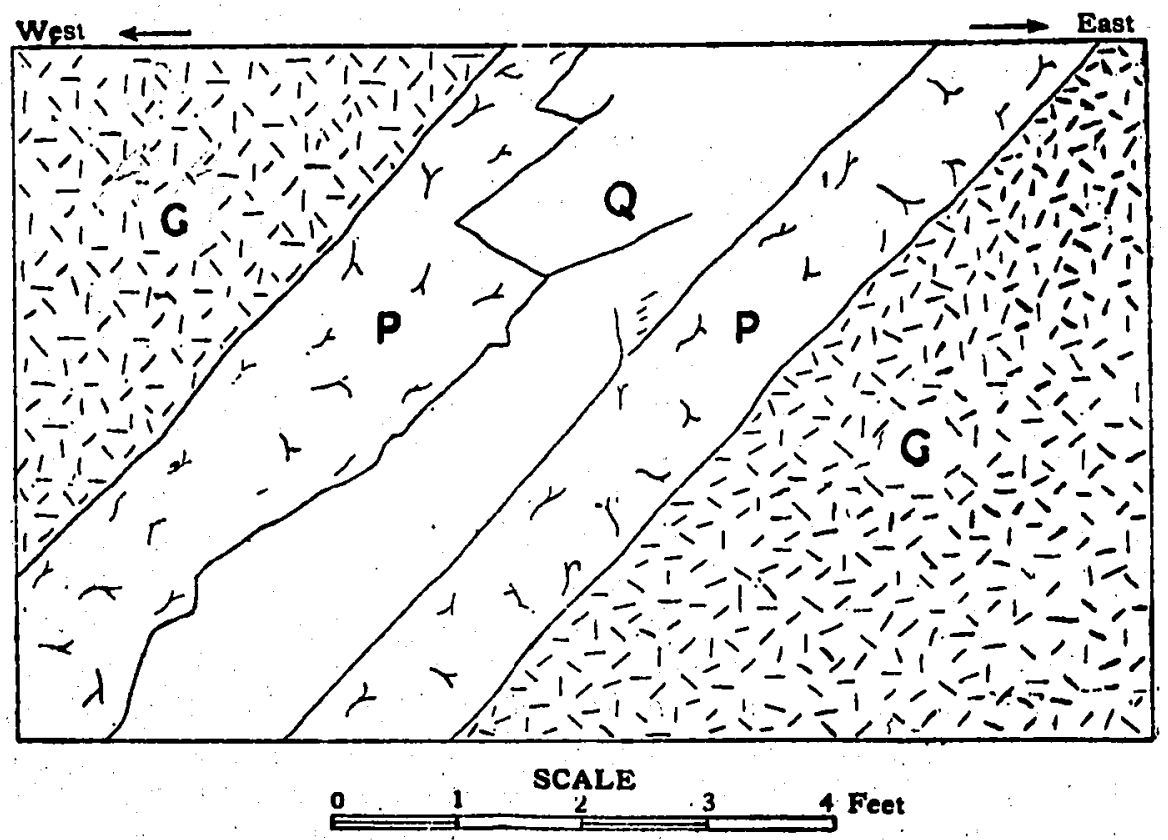

Fig. 3.-Vertical section showing pegmatite dike cutting granite near Rivanna Mills. $G$, granite; $P$, fine-grained pegmatite; $Q$, quartz with a little feldspar and pyrite. 
South of Riyanna Mills and also in the road three-quarters of a mile to the east there are numerous exposures of hornblende schist, and in the latter locality they are occasionally cut by small pegmatite dikes.

Carysbrook bridge.-On the enst side of Rivanna River, 150 yards below the road leading from Carysbrook to Wilmington, there is an exposure of granite (Spec. 61) containing feldspar phenocrysts ranging up to $1.5 \mathrm{~cm}$. in diameter. The rock contains much less biotite than most of the granites previously described, and is only slightly schistose.

Examined under the microscope, acid plagioclase is seen to be dominant with only minor quantities of orthoclase present. The feldspars show twinning after the albite, Carlsbad, and pericline laws, and in places there are micrographic intergrowths with quartz. The larger individuals frequently show evidence of having been bent and broken prior to the complete solidification of the rock, for the fractures are filled with minerals of later crystallization. The feldspars have been extensively altered to epidote, which is present in irregular rounded grains and in granular aggregates. The quartz contains rutile needles, imperfect zircons, and numerous fluid inclusions some of which show moving bnbbles. There is also a small amount of light brown biotite present, but it is largely altered to chlorite. Pyrite is of occasional occurrence in small, cubical crystals, which show more or less alteration to limonite.

A specimen (60) of the granite obtained about 20 yards above the Carysbrook bridge is typical of most of the rock in this vicinity. It is slightly schistose in structure, the feldspars are gray in color, and the biotite is not very plentiful.

In thin section under the miscroscope it is seen that soda-lime feldspars (probably oligoclase) are dominant over the potash feldspars (orthoclase with a little microcline). The larger feldspars are frequently bent, or ruptured and faulted, and in some cases thie fractures are filled with minerals of later crystallization, indicating that there were probably differential movements in the magma after crystallization had commenced and before the rock had completely solidified. The feldspars show twinning according to the albite, Carlsbad, and pericline laws, and they are more or less altered with the production of sericite, kaolin, epidote, and a little calcite. Biotite is present in small light green flakes partly altered to chlorite. The quartz contains numerous fluid inclusions and occasionally moving bubbles. Tourmaline is of sparing occurrence in light brown crystals with ragged outline.

Carysbrook.-A quarry, opened in the granite to obtain rock for use in building the railroad, is located on the south side of Rivanna River, at 
the Virginia Air Line railroad bridge, a mile northwest of Carysbrook. This quarry is within 100 yards of the contact between the granite and a chloritic slate which lies on the west.

The rock exposed in the quarry is exceedingly variable in appearance; there are irregular areas or blotches of coarse-grained granite, ranging up to a foot or more in diameter, which are surrounded by a ground-mass of finer material; and the entire rock-mass is cut by irregular fractures running in every conceivable direction. Differential movements have taken place along some of these fractures, resulting in the formation of slickensided surfaces and the production of a little light green chlorite.

The masses of coarse-grained granite are composed essentially of feldspar, quartz, and biotite, with a little pyrite in places. Some of the feldspars are $1 \mathrm{~cm}$. in diameter, but the larger ones are frequently fractured and broken. They are white to light gray in color and occasionally show coarse multiple twinning. The biotite flakes, which range up to 0.5 $\mathrm{cm}$. in diameter, have no regular orientation, and the rock shows little evidence of regular schistosity. In places the rock is cut by narrow veinlets, 1 to $2 \mathrm{~mm}$. wide, which are largely composed of feldspar similar to that of the inclosing granite.

The fine-grained facies of the rock contains little or no biotite, consisting chiefly, of feldspar and quartz; and as it has a uniform light gray color it is difficult to distinguish between the two minerals. A little calcite occurs in places along some of the fracture lines.

Some of the granite found in the quarry and at other localities in the vicinity contains feldspars that are pink instead of gray in color, but this difference is probably due to alteration with the production of some ferric oxide, as the pink and gray varieties of rock are apparently similar in other respects.

A thin section of the coarse-grained, gray granite was examined under the microscope. ${ }^{a}$ The feldspars occur in large individuals, ranging up to 5 or $6 \mathrm{~mm}$. in diameter, and are frequently fractured and faulted, while the fissures as well as the interstitial spaces are filled with minerals of later crystallization, chiefly quartz and feldspar. Soda-lime feldspar (oligoclase?) is probably dominant over the potash feldspars (orthoclase with less microcline), but the latter are abundant, and in places may equal the former. The plagioclase shows fine multiple twinning and is much altered by kaolinization, while calcite is also present as a secondary product. Grasty.

a'This thin section (Spec. 18) was made from a specimen collected by Dr. J. $\mathbf{S}$. 
Liquid- and gas-filled cavities occur in some of the fresher feldspars and are abundant in the quartz. Quartz is not as plentiful as in the granites near the James River section. A few of the individual grains show optical distortion and fracturing, but most of them show no pressure effects. Biotite occurs in brownish-green flakes that are of later formation than most of the feldspar, and in places appears to have partly replaced potash feldspar. Chlorite is also present, probably as an alteration product of biotite. Pyrite is one of the minor accessories, occurring frequently in association with biotite-often along the cleavage planes. Ilmenite, partly altered to lencoxene, is present in small grains.

The thin section is crossed by a number of narrow, branching veinlets composed of fine-grained feldspar and quartz, with a little biotite and chlorite. These veinlets cut directly across the larger feldspars and other minerals.

A thin section of the pink granite, which was examined under the microscope, shows no essential difference from the rock described above. The feldspars have undergone greater kaolinization, the biotite is entirely altered to clilorite, and there is a little hornblende present, part if not all of which is secondary. A few ragged crystals of reddish-brown tourmaline, a little magnetite or ilmenite, and scattered grains of titanite are among the minor constituents. The rock is cut by narrow, branching fractures filled with clark green chlorite.

Granite similar to that exposed in the quarry extends southward beyond Carysbrook, and in the railroad cut half a mile south of the station, Ordovician sediments may be seen lying upon the eroded surface of the granite. Most of the rock is badly decomposed, but all fiesh specimens seen were nearly massive in texture. 'The granite in this vicinity is essentially the same as the rock exposed at Carysbrook briclge (see description of Spec. 60, p. 75) excepting that the latter is markedly schistose.

\section{Gold Hill Granite Area.}

GENTERAL DESCRIPTION.

The Gold Hill granite area lies between Kent's Store and Tabscott, in the northeastern portion of the region mapped. A general description of the area is given under the discussion of the country rock in the vicinity of the Gold Hill vein system (see pp. 176-177), and therefore will not be repeated here. 
DETAILED DESORIPTIONS.

McGloam mine.-The granite (Specs. 161 and 166) exposed on the dumps at the McGloam mine is typical of much of the rock in the Gold Hill area. It is light gray, fine-grained, even-granular, and the minerals distinguishable megascopically are feldspar, quartz, small flakes of dark green chlorite, a little sericite, numerous cubes of pyrite, and occasional grains of magnetite.

Examined under the microscope the rock is seen to vary from granitic to granophyric in texture. The feldspar is probably chiefly acid plagioclase, but twinning can seldom be distinguished. Orthoclase is also present and fine intergrowths of feldspar and quartz are plentiful. A little biotite occurs in the rock, but most of it seems to have been altered to chlorite. Sericite and calcite are fairly abundant as secondary minerals, probably derived from feldspars. The minor accessories include pyrite, magnetite, zircon, leucoxene, apatite, and rutile needles. Fluid inclusions are common in some of the quartz grains.

This rock, which is fairly representative of the granite in the Gold Hill area, differs from the granites previously described in being finer-grained, with a greater development of micrographic intergrowths of quartz and feldspar, and in having no schistosity. It contains less biotite and a relatively larger proportion of some of the minor accessories, such as pyrite and magnetite.

Pieces of hornblende schist are present on the dump of the incline shaft, but the schistosity is not so well developed as in most of the hornblende schists of the district. The rock (Spec. 167) is dark green in color and rather coarsely crystalline, containing bladed crystals of hornblende that range up to $1 \mathrm{~cm}$. in length. The other minerals distinguishable megascopically are white feldspar and quartz, a little chlorite, and numerous small grains of magnetite and pyrite. Under the microscope it is seen that the hornblende is irregular in outline and contains numerous inclusions of quartz and feldspar, and in places there are graphic intergrowths of quartz and hornblende. The feldspar is unstriated plagioclase, probably albite. A little chlorite is present as an alteration product of hornblende, and rutile needles occur in some of the quartz grains.

Another variety of rock (Spec. 165) present on the dump is a chlorite schist containing scattered cubes of pyrite 2 to $5 \mathrm{~mm}$. square, and octahedrons of magnetite ranging up to $2 \mathrm{~mm}$. in diameter. Examined under the microscope, the chlorite is seen to be secondary from hornblende, of which many unaltered fragments remain. Aside from the alteration of 
hornblende to chlorite, the rock is essentially the same as the hornblende schist described above.

Big Byrd Creek,-On the road, a quarter of a mile north of Big Byrd Creek and 11/4 miles southeast of Kent's Store, there is an outcrop of greenish-gray granite (Spec. 82), which is slightly coarser-grained than most of the rock in the Gold Hill area. Some of the feldspars are 2 or 3 $\mathrm{mm}$. in diameter, and multiple twinning can occasionally be distinguished with the naked eye. Other minerals which may be identified in the hand specimens are quartz, chlorite, magnetite, garnet, and pyrite.

Under the microscope the rock is seen to be composed almost entirely of micrographic intergrowths of feldspar and quartz, the feldspar consisting of orthoclase, acid plagioclase, and microcline in the order named. Feldspar phenocrysts, $3 \mathrm{~mm}$. in length, are scattered through the rock, and in their border portions are intergrown with quartz. Small grains of magnetite and of ilmenite partly altered to leucoxene are present. There is only a little mica-biotite and sericite-in the rock, but chlorite probably derived from biotite is common. Garnets, light pink in color, are of frequent occurrence; they usually contain numerous inclusions of quartz, and in places show micrographic intergrowths. Small zircons are plentiful as inclusions; in the larger crystals of quartz.

About 10u yards north of the rock just described there are outcrops of hornblende schist, and the rock with which it is in contact is intermediate in mineral composition between the typical granite of the Gold Hill area and the hornblende schist.

A specimen (83) of this rock is white to light gray in color, finegrained, and contains small prisms of dark green hornblende in a white ground-mass. There may also be distinguished a few small phenocrysts of feldspar, quartz, a little pyrite, small grains of magnetite, and occasional pink garnets. Under the microscope, the feldspar phenocrysts, ranging up to $2 \mathrm{~mm}$. in length, are seen to be acid plagioclase; they are very irregular in outline, are often broken, and have a corroded appearance. The ground-mass, consisting chiefly of quartz and feldspar, frequently shows micrographic intergrowths. The hornblende shows idiomorphic outlines, is dark-colored, and strongly pleochroic. A little chlorite is present, probably as an alteration product of the hornblende. Ilmenite partly altered to leucoxene and minute inclusions of zircon make up the remaining accessories.

About half a mile south of Big Byrd Creek and 11/2 miles southeast of Kent's Store there are outcrops of chlorite schist in the road. The 
schist (Specs. 80, 81, and 160) is clearly derived from a hornblendebearing rock, and under the microscope fragments of unaltered hornblende can be identified. The rock which has undergone the least alteration shows the least schistosity. Small grains of pink rutile are scattered through the rock and can be easily recognized with the naked eye.

Examined microscopically the rock is seen to consist largely of chlorite and needles of secondary hornblende. Unstriated plagioclase feldspar, quartz, and unaltered fragments of primary hornblende are also present, together with numerous small grains of rutile and titanite, and a few inclusions of zircon. The titanite is partly if not entirely secondary after rutile and some of the larger masses contain nuclei of the unaltered mineral.

Hughes farm.-On the Hughes farm, half a mile northwest of the Tellurium mine, numerous pieces of breccia are found on the surface. The rock (Spec. 207) consists of angular and subangular fragments of quartz, feldspar, and fine-grained garnets, which have been more or less silicified and recemented by silica. Small cavities, lined with quartz crystals are occasionally present, and the secondary silica contains a little pyrite. The texture of much of the cementing silica, when it is examined megascopically, suggests that it was originally deposited as calcedony and subsequently altered to quartz. The fragments of country rock are largely replaced by silica.

The distribution of this rock in a northwest and southenst line, a quarter of a mile or more in length, suggests that the breccia was formed by faulting, and that the cementing silica was deposited by solutions circulating along the fracture.

\section{Rosney Granite Area.}

There is a considerable area of granite in the vicinity of Rosney, the terminus of the Buckingham Branch of the Chesapeake and Olio Railway, but because of the lack of outcrops it is not possible to determine its precise extent. On the west it is in contact with quartz-sericite schists and on the east similar schists intervene between the Rosney area and the granite of the Columbia area. It is not improbable, however, that the two areas are connected beneath the sediments of the Farmville Triassic area, which lies a short distance to the southeast.

The granite is fine-grained, very schistose, and varies in color from light to dark gray. A specimen (383) from an outcrop in the road about three-quarters of a mile northwest of Rosney, contains both biotite and hornblende, the two minerals being distinguishable from each other with 
difficulty in the hand specimen. In a thin section, which was examined under the microscope, the feldspar was all plagioclase (oligoclase), and no potash feldspar could be identified. Twinning after the albite law is abundant and occasionally a little twinning after the pericline law may . be seen. The hornblende is dark green in color and frequently shows idiomorphic boundaries; the biotite varies from brown to green and is strongly pleochroic. Both minerals show alteration to epidote, but no chlorite was identified. Many of the quartz and feldspar individuals are fractured and show optical distortion. Ilmenite, largely altered to leucoxene and limonite, and idiomorphic crystals of zircon make up the minor accessories.

Between the rock just described and the contact, about half a mile northwest, there are no outcrops, but the residual decay indicates the presence of several bands of hornblende schist. In the road half a mile southwest of Rosney a fine-grained hornblende schist is exposed. It is a dark gray, even-granular rock composed for the most part of feldspar, hornblende, quartz, and a little biotite, with occasional small pink garnets.

On the north side of Whispering Creek, 2 miles south of Rosney, several pieces of porphyry were found, which probably belong to a dike, as the country rock in this vicinity is chiefly quartz-serjcite schist. The rock is only slightly sclistose and is therefore probably of later origin than the granite near Rosney, but it is not improbable that there is some genetic relation between the two occurrences.

The rock (Spec. 388) contains numerous light gray, rounded phenocrysts of feldspar, 5 to $6 \mathrm{~mm}$. in diameter, which are surrounded by a ground-mass of fine-grained hornblende, feldspar, and quartz. Multiple twinning can be distinguished in places with a pocket lens, but most of the feldspars have a rough fracture because of the presence of microscopic inclusions. On weathering the rock gives a deeply pitted surface due to the early decomposition and removal of the feldspar phenocrysts.

Under the microscope the large feldspars are seen to be micropoikilitic in texture, being full of inclusions of quartz and hornblende that range in size up to $0.2 \mathrm{~mm}$. in diameter; they have indefinite boundaries that grade into the surrounding ground-mass; and the extinction angles and index of refraction indicate a composition near labradorite. The hornblende is light green to nearly colorless and contains occasional inclusions of quartz. The quartz grains contain numerous fluid inclusions, and irregular rounded grains of titanite are plentiful, some of them containing nucleal fragments of light yellowish rutile. 
About a mile west of Rosney and not far from the contact, there is a large amount of tourmaline present on the surface. Most of it occurs in long black prisms imbedded in vein quartz, but large masses were seen that consisted almost exclusively of small interlaced needles of tourmaline.

\section{Granite at Greeley Inine.}

Granite occurs in one of the openings of the Greeley mine, but there are no surface exposures and the occurrence is probably limited in its areal extent. The rock is described in detail on pages 206-20\%. The appearance of the rock, and the presence of much calcite and coarsely crystalline muscovite, suggests that extensively pneumatolitic action accompanied or followed the intrusion of the granite.

\section{Porphyries.}

- DISTIRIBUTION AND GENERAT DESCRIPTION.

In the district lying between the Gold Hill granite area and the Wilmington embayment of the Columbia area, there are a number of outcrops of feldspar porphyry. Lack of sufficient exposures makes it impossible to determine the size and character of these bodies, but most of them are limited in extent, and sloould probably be classified as dikes. The other rocks occurring in this district are chiefly chlorite schists, hornblende schists, quartz-sericite schists, and quartzites, all of which are-intensely metamorphosed.

The porphyries contain phenocrysts of feldspar ranging up to $2 \mathrm{~mm}$. in length, and occasionally small eyes of quartz embedded in a fine-grained ground-mass composed essentially of feldspar, quartz, and wsually a little hornblende, which may be more or less altered to chlorite and epidote. They vary considerably in composition, particularly in the amount of ferromagnesian mineral present. The phenocrysts are frequently fractured and the fragments separated, indicating that important differential movements took place during the crystallization of the rock.

The composition of the porphyries, their texture, and their distribution relative to the larger granite arens, are all indicative of their close genetic relationship to the granite and point toward an approximate contemporaneity of origin. Some of them are closely similar to the granite in the Gold Hill area.

\section{DETAILS OF OCOURRENCES.}

In the road $1 \frac{1}{2}$ miles northeast of Wilmington there is an outcrop of. porphyry. It is a light greenish-gray rock (Spec. 63), fine-grained, and 
slightly schistose. A few phenocrysts of feldspar, $1 \mathrm{~mm}$. in length, and small flakes of light green chlorite are the only minerals distinguishable megascopically.

Under the microscope the phenocrysts are seen to be well-formed crystals of acid plagioclase, nearly $1, \mathrm{~mm}$. in length, which show twinning after the Carlsbad and albite laws. They are occasionally broken and the fragments separated by minerals of later crystallization. The groundmass is fine-grained, even-granular, and consists of feldspar, quartz, chlorite, small needles of hornblende, a few flakes of biotite, calcite, epidote, and small inclusions of zircon, titanite, apatite, and rutile.

Another outcrop occurs half a mile farther east where the rock (Spec. 66) is essentially the same. The phenocrysts are slightly larger, ranging up to $1.5 \mathrm{~mm}$. in length, there is a small amount of magnetite present, and alteration las been carried a little farther, so that epidote is more plentiful, occurring in granular aggregates with quartz and a little chlorite.

On the southwest side of Big Byrd.Creek, $21 / 2$ miles southeast of Wilmington, there is an outcrop of schistose porphyry. The rock (Spec. 68 ) is light gray with dark blotches due to areas of fine-grained biotite, and contains lenticular eyes of quartz, $4 \mathrm{~mm}$. in length. A few feldspars, crystals of pyrite, red garnets, and a little fine-grained magnetite may also be distinguished in the hand specimen.

Under the microscope phenocrysts of acid plagioclase, over $2 \mathrm{~mm}$. in length, can be identified; and many of them are broken and split apart along cleavage planes, the fractures being filled with the minerals of the ground-mass. The lenticular eyes of clear, granular quartz contain fluidfilled cavities and numerous inclusions of idiomorphic zircon and rutile needles. The ground-mass is fine-grained and consists of feldspar, quartz, flakes of brown biotite partly altered to chlorite, and a little pyrite, magnetite, titanite, and zircon.

In a branch on Mr. Williams' farm, 11/4 miles northeast of Rivanna Mills, a rock (Spec. 54) is exposed which is light gray, fine-grained and only slightly schistose. Small pink garnets, pyrite, flakes of light green chlorite, and a little fine magnetite may be recognized with the naked eye. Examined microscopically the feldspar phenocrysts are seen to be smaller than in the rocks previously described, and they are much corroded; the ground-mass is coarser grained, but otherwise the same. The surrounding rock is probably granite, but there are no exposures in the immediate vicinity.

At the road corner, 21/2 miles south of Kent's Store, there is an out- : crop of fine-grained, bluish-gray rock (Spec. 128) containing small eyes 
of quartz 0.5 to $2 \mathrm{~mm}$. in diameter. Uncler the microscope no feldspar phenocrysts could be identified; the quartz eyes contain rutile needles and well-formed zircons; and the ground-mass is composed essentially of feldspar, quartz, much hornblende in slender green prisms, and a large amount of fine-grained magnetite. A little zircon, titanite, and apatite are present as minor accessories. A similar rock found 50 yards enst contains no eyes of quartz.

A rock (Spec. 62), having a ground-mass similar to the one just. described, was obtained from a well near the road 3 miles northeast of Stage Junction. Instead of having eyes of quarty there are a few imperfect phenocrysts of feldspar less than $0.5 \mathrm{~mm}$. in length.

A quartz porphyry, differing in texture and mineral composition from the rocks clescribed above, occurs at the Morton mine, half a mile west of Jolmson, Buckingham County. A microscopic description is given on pages 197-198.

\section{CAMBRIAN OR POST-CaMBRIAN. Diorite Dikes. \\ DISTRIBUTION AND GENERAL CHLARACTER.}

Dikes of altered diorite occur at several places in the area mapped, but there are a few good exposures, and the rock is of little importance as an areal formation. All occurrences that were observed are practically identical in appearance and mineral composition. The rocks were originally composed essentinlly of hornblende and plagioclase feldspar, but the latter mineral is now almost completely altered to a fine-grained aggregate of zoisite, epidote, and other secondary products.

AGE.

Since these rocks show little or no evidence of dynamic metamorphism, they must be younger than the pre-Cambrian rocks into which they have been intruded; and the fact that some of them are very slightly schistose indicates that they solidified before the close of the crustal movements which deformed the Ordovician rocks. For these reasons the diorite dikes are believed to be Cambrian or possibly Ordovician in age, but they may be younger.

DELAILS OF OCOURRENCES.

Palmyra.-A dike of partly decomposed diorite outcrops in the road near the northwest corner of the Courthouse yard at Palmyra, but the size of the dike could not be determined. The rock is composed essentially. 
of partly altered feldspar and dark green hornblende, and shows marked schistosity in the hand specimen. Under the microscope the feldspars are seen to be almost entirely altered to saussuritic aggregates of epidote, zoisite, and other secondary minerals, but in places a few residual fragments of basic plagioclase can be identified. The hornblendes are ragged in outline and show partial alteration to chlorite.

Long Island Creek.-The county road from Palmyra to Wilmington crosses a dike of weathered diorite about 100 yards east of Long Island Creek. The dike appears to be $\mathbf{1 0 0}$ yards or more in width, but could not be traced for any distance because of the lack of exposures. The strike is probably northeast and southwest. The rock is similar in appearance and composition to that described above, excepting that the percentage of hornblende present is slightly greater and the schistosity is scarcely noticeable.

Benton mine.-Pieces of weathered diorite were found on a rock pile in the vicinity of the shaft at the Benton mine. The rock (Spec. 221) is massive, even-granular, and shows no evidence of schistosity. It consists of green hornblende in crystals 1 to $2 \mathrm{~mm}$. in diameter, which are uniformly distributed through a fine-grained, white ground-mass resulting from the alteration of feldspar. Under the microscope the feldspars are seen to be almost completely altered to secondary minerals, chiefly zoisite and epidoto The hornblende shows partial alteration to chlorite, and a little quartz, probably secondary, may also be distinguished.

Bowles mine.-On the Bowles tract, about $11 / 4$ miles west of Tabscott, pieces of diorite float were found on the surface, but no outcrops could be discovered in place. The rock is similar in every way to that which occurs at the Benton mine.

TRIAssic.

Diabase Dikes.

DISTRIBUTION AND GENERAL OHARACTER.

Diabase dikes, or trap rock as they are commonly called, are of occasional occurrence in all portions of the area mapped. They are in no wise different from the other dikes belonging to the same great series, which are found intersecting the older rocks all along the Atlnntic slope from Nova Scotia to Alabama. These dikes are especially abundant in some of the Triassic areas, and cut all formations excepting the Cretaceous and later sediments of the Coastal Plain.

In the area covered by the present report the diabase dikes vary in width from a few inches to 200 or 300 feet, and at least one of them can be traced 
for a distance of orer a mile, its course being marked by occasional outcrops, and the black weather-beaten bowlders, which are locally called "nigger-heads." The dikes are usually approximately parallel to the strike of the enclosing rocks, and are nearly vertical.

The diabases are dark brown to black in color, and vary from medium fine-grained to aphanitic in texture. They are composed essentially of lime-soda feldspar, augite, and magnetite, while olivine is present in some and absent in others. These rocks are exceedingly hard and tough, and on account of this fact together with their good cementing qualities, they make excellent material for macadamizing roads.

\section{DETAILS OF OCCURRENCES.}

Columbia.-One of the largest and most persistent dikes in the district is exposed in the county road, a mile northeast of Columbia, where it is possibly 100 yards wide. It has a strike of approximately N. $15^{\circ}$ E., and can be traced in a southwest direction as far as the river. The large outcrop of diabase half a mile east of Stage Junction lies in the same line of strike and may be a continuation of this dike, but lack of exposures makes it impossible to trace it on the surface.

The rock (Spec. 46) is dark brown, and rather coarse-grained, showing a marked ophitic texture even in the hand specimen. The feldspars range up to $8 \mathrm{~mm}$. in length, and show polysynthetic twinning to the naked eye. Examined under the microscope the rock is seen to be composed of plagioclase, augite, magnetite, pyrite, and occasional flakes of biotite. The augite is mostly colorless in thin sections, but in places is finely twinned with a light green variety. Magnetite and pyrite are both plentiful in small irregular grains The biotite is dark brown, strongly pleochroic, and shows partial alteration to chlorite. No olivine was identified.

Grannison mine.-A dike of olivine diabase outcrops near the old mill at the Grannison mine, three-quarters of a mile south-southwest of Pryors Crossroads. It has a strike of approximately $N$. $25^{\circ} \mathrm{W}$., but the width and length could not be determined. The rock is coarse-grained and the ophitic texture easily distinguishable to the naked eye. Examined under the microscope (Spec. 97) it is seen to consist of lime-soda feldspars, augite, much olivine, a few grains of magnetite, less pyrite, and a little carbonate (probably. calcite). The feldspars occasionally show pericline as well as albite twinning, and zonal extinction is common. The carbonate is probably derived from the alteration of feldspars. 
Pemberton.-A mile west of Pemberton, a diabase dike is exposed on either side of the narrow neck of land formed by the sharp bend in the river. Where well exposed the dike is only 5 or 6 feet wide, and while approximately vertical is very irregular in its dip. The strike is nearly north and south. The rock (Spec. 24) is medium-grained, even-granular, and dark gray in color. Under the microscope it shows the typical ophitic texture, and is composed of plagioclase, augite, and small idiomorphic grains of magnetite partly altered to limonite. The rock cut by the dike is a fine-grained, light gray granite-gneiss.

Dillwyn.-A dilie of olivine diabase outcrops in the town of Dillwyn (see map, p. 185), and a similar dike, which is described on page 18\%, is found near the London and Virginia mine, three-quarters of a mile north of Dillwyn. The rock is dark brown in color, medium coarse-grained, and is composed of plagioclase, augite, olivine, and magnetite. The olivine shows extensive alteration to sepentine.

Other localities.-Several dikes of weathered diabase are exposed in the bluffs on the south side of James River near New Canton, and similar dikes were observed cutting the Ordovician slates. Diabase dikes at the Bondurant and McKenna mines are described on pages 195 and 254 , respectively. Other occurrences are too numerous to mention in detail, and none of them differs in any material way from those already described. 


\section{CHAPTER III. PHYSIOGRAPHY.}

\section{INTRODUCTION.}

Virginia is naturally divided into three major provinces: (1) the flatlying Coastal Plain which extends from the continental shelf, now 30 to 50 miles east of the present shore-line, to the fall-line at the head of tidewater; (2) the Piedmont Plateau extending from the Coastal Plain on the east to the foot of the Blue Ridge; and (3) the Appalachian Mountains province which embraces the western or mountain portions of the State. (See fig. 1.)

The Piedmont Plateau lying between the Coastal Plain and the Appalachian Mountains has a width of about 40 miles in the northern portion along Potomac River, but going south it widens until at the VirginiaCarolina state-line it extends for nearly 175 miles. The district under consideration is located in the center of the Piedmont Plateau province where the width is about 75 miles. The district presents the general surface features characteristic of the Piedmont Plateau throughout Virginia; low relief, a network of streams which afford perfect drainage to the region but which are heavily loaded with sediment, and a deep mantle of residual decay which covers most of the country except where the larger streams have cut down their valleys into the underlying rock.

\section{RELIEF.}

The elevations indicated on the map of the area (see Pl. I, in pocket at back of book), by means of contour lines, are approximately correct, and serve to portray the principal physiographic features. The topography, as shown on this map, is adopted from the topographic sheets of the United States Geological Survey, with corrections by the writer.

The most characteristic feature of the relief is the absence, over the entire area, of any notable elevations, with the single exception of Willis Mountain. This fact is forcibly impressed on the observer by the bird's-eye view of the country obtained from the top of Willis Mountain. Looking from this elevation, the country appears as a broad, flat plain, stretching from the foot of the mountain toward the north, east, and south as far as the eye can reach, while toward the west it is limited only by the foothills of the Blue Ridge. 
In traveling any great distance across country, one sonn finds that the surface instead of being perfectly level, is gently rolling, and consists, for the most part, of broad, flat-topped ridges and comparntively narrow valleys. If, however, one follows one of the main ridge roads, which have from the earliest days been the chief transportation routes of the country, the illusion of a vast level plain is maintained, for many of the ridges extend along distances with little variation in altitude. Thus, in traveling over the roads that lead from Cartersville to Cumberland, New Canton to Dillwyn and Buckingham, or from Stage Junction north by way of Wilmington, one may go for distances of 15 or 20 miles over an apparently level country.

Glancing at the map, it is seen that neighboring ridges have approximately the same elevations, but that in passing across the area from east to west the height of the elevations gradually increases; along the eastern border of the area the ridges are about 450 feet above sea level, while in the western portion they average from 550 to 600 feet in elevation. If it were possible to fill in all of the valleys level with the tops of the ridges, we would have a broad, flat plain sloping gently toward the ocean, and it is believed that this was the condition of the land surface at a former period, before the, streams had cut their channels down to their present levels.

The rivers and larger creeks have cut their valleys deepest, about 250 feet below the present surface of the old peneplain, the smaller creeks somewhat less deeply, and their tributary branches only from 50 to 150 feet. All of the larger streams flow through narrow trench-like valleys with very limited bottom lands. In places where the rocks are especially resistant, as is the case with the quartzite beds at Bremo Bluff, the river lowlands are practically absent and the stream is bordered by almost vertical cliffs. (See Pl. III, and fig. 2.)

Willis Mountain, in the southwestern corner of the area, projects abruptly from the average level of the Piedmont Plateau and rises to a height of 1,159 feet above sea level. It is a prominent feature of the landscape for miles around, and is the most noticeable elevation found in the State, east of the outlying ranges of the Blue Ridge. (See figs. 4 and 5.) Topographically, it is a narrow ridge extending about two miles in a north and south direction, and the crest of the ridge is formed by a narrow wall of rocks, perhaps 100 feet high; which is so nearly vertical that it can be scaled only in places and with difficulty. (See Pl. IV, fig. 1, and Pl. VI, fig. 2.) The dip of the strata is slightly toward the west, and the 
large fragments which have fallen along the eastern base have rendered this the easiest direction of ascent. From the foot of this wall-like precipice the mountain slopes steeply down to its base. The rocky ridge

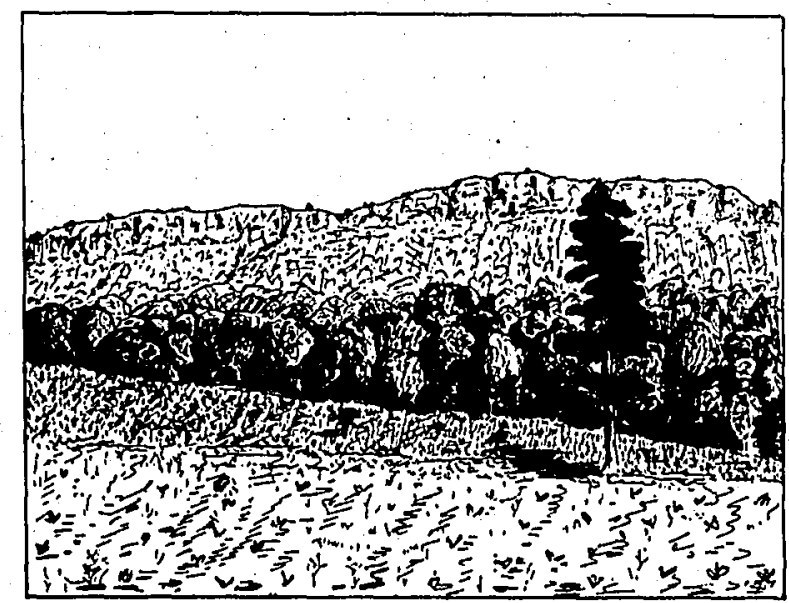

Fig. 4.-North end of Willis Mountain from the west.

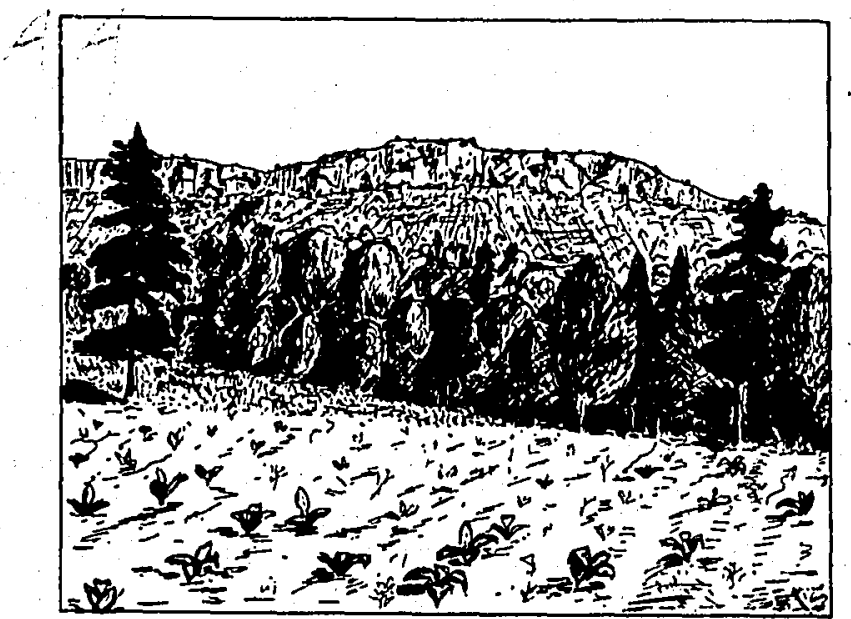

Fig. 5.-South end of Willis Mountain from the west.

forming the crest of the mountain is notched in several places, so that a number of distinct summits occur. The deepest of these notches is near the south end of the mountain, and the southern knob which it separates from the main ridge is locally known as Round Mountain. Willis 
Mountain owes its origin to the resistant nature of the cyanite schist which outcrops along its crest, and which has offered greater resistance to erosion than any other rock in the region.

\section{DRAITAGE.}

The great master-stream of the area, James River, flows in a general southeasterly direction and cuts directly across the strike of the upturned edges of the rock strata, maintaining its course without reference to variations in their hardness. With its headwaters rising among the ridges of the Alleghany Mountains, James River flows eastward, cutting its way through the Blue Ridge as well as all minor barriers that rise athwart its course, and finally empties into the Atlantic Ocean. This independence of the chief structural features of the country, together with its intrenched meandering curves, proves that the river- developed its course on a broad, level plain, before the present ridges were formed. Such a river is called an antecedent stream.

The principal streams draining the area and entering James River from the north are Rivanna River and Byrd Creek (see map, Pl. I). Both of these flow southeasterly across the strike of the upturned rock strata and show deeply trenched winding valleys, indicating that they are also antecedent strénms:

Slate and Willis rivers are the largest streams that cross the area and enter the James from the south. It should be noticed that both rivers, after flowing in a general northeasterly direction throughout most of their length, suddenly change their courses as they approach the James, and enter it from an easterly or even a northeasterly direction; and, moreover, their lower courses are extremely crooked, while their upper valleys are fairly straight. These two rivers were doubtless at one time superimposed streams similar to those on the other side of James River, but as their direction of flow was nearly parallel to the strike of the rock strata, their courses were more easily modified and adjusted to the rock structure. This possibly explains the peculiarities in the courses of these streams and also the fact that their valleys are slightly broader and less steep than those of the corresponding streams on the opposite side of James River. Slate and Willis rivers may be considered as antecedent streams that have subsequently undergone modification and are now in partial adjustment to the structure.

Appomattox River, which crosses the southeast corner of the area, is clearly another antecedent stream similar to James River into which it flows some distance beyond the borders of the map. 
It is thus seen that all the larger streams of the area are either antecedent streams or streams that are only in partial adjustment to the structure, and that they all show a strong tendency to flow in a southeasterly or easterly direction.

Most of the creeks and many of their branches are streams that owe their location to the underlying rock formations. These streams flow northeasterly or southwesterly parallel to the structure of the country, their direction of flow being controlled by their proximity to some larger antecedent stream. Hunt Creek, Phelps Creek, and Little Byrd Creek may be mentioned as good examples of structural control of drainage.

Hunt Creek has eroded its valley in the long, narrow area formed by the Arvonia slate belt, while the ridges on either side are composed of more resistant rocks-schistose quartzites and conglomerates.

Phelps Creek runs in a northeasterly direction through an area of highly metamorphosed schists and enters James River just east of New Canton. The ridge on the west side of the valley is composed of quartzite, while on the east stretches the granite area. A complementary creek flows southwest and enters James River directly opposite.

Little Byrd Creek flows southwest within the area of pegmatite, which is less resistant than the granite and hornblende schists on either side.

The hindreds of small tributary branches that drain into the larger streams flow in every conceivable direction, their courses being controlled partly by the geological structure, but chiefly by their proximity to one of the larger streams.

Most of the streams draining this area are rather swift and flow over occasional rapids, due to outcropping ledges of harder rock; their waters are usually muddy because of the large amount of fine material carried in suspension which has been derived from the residual soils that almost everywhere cover the underlying rocks.

It is interesting to note that in the case of some of the larger streams that are in structural adjustment, such as Little Byrd Creek on the north side of James River and Muddy Creek on the south, the principal tributary branches all enter from the west. This phenomenon is due to the eastern slope of the peneplain in which the streams have eroded their valleys.

The movement resulting in the tilting of this plain did not take place all at once, but undoubtedly extended over a long period of time, and was probably interrupted by periods of quiescence. Every increase in the eastern tilt of the land surface resulted in an increased velocity of the streams flowing in an easterly direction with a corresponding increase in

-. 
their powers of erosion. Streams flowing westward had their velocities diminished and if the amount of movement was sufficient the direction of flow may even have been reversed in some cases. The net result of this tilting was to cause the streáms flowing in an easterly course to cut backward and lengthen their valleys faster than the streams flowing in the opposite direction. This process may have been accompanied by an easterly migration of the parent stream since the tilting would tend to induce greater erosion along the eastern bank. The bluffs appear to be somewhat more prominent on the east sides of these streams than on the west, but the difference is certainly not great. The chief result of any easterly displacement of the parent stream would be to lengthen the courses of its tributaries from the west and shorten those from the east, but it is not believed that this was an important factor in producing the unsymmetrical streams described above.

The rapid headward erosion of easterly flowing streams, caused by the tilting of the peneplain would bring about a condition favorable to stream capture; that is to say, the stream with greater velocity might cut its way back to some neighboring stream and divert the upper portion of its drainage. A close study of the region lying west of Little Byrd Creek indicates that this may have taken place, and that the headwaters of some of the branches north of Lantana, which now flow east into Little Byrd Creek, at one time drained southward into the large branch which enters Little Byrd Creek a mile above its mouth.

The principal facts in favor of this theory are as follows:

(1) The large branch which heads just east of Lantana and flows south into Little Byrd Creek has a valley that is almost as broad as that of Little Byrd Creek itself.

(2) The divide near the headwaters of this brancl is low and in places swampy.

(3) Several of the tributary branches draining the area northeast of Lantana have a sharp bend in their courses which is approximately in alignment with the prolongation of the valley running south from Lantana.

(4) On some of the low ridges northeast of Lantana residual patches of placer gravel were formerly worked for gold. The position of this gravel is high above any of the neighboring streams, and these remnants are all that is left to indicate the location of an old stream bed which has long since been almost entirely removed by erosion.

\section{PHYSIOGRAPHIC HISTORY.}

It is known that this region passed through a long and varied history before the present physiographic features began to take form; it underwent 
many changes in elevation, and for long periods of time it was depressed below sen level while the great series of sedimentary beds was being deposited. Later these beds were consolidated into hard rock and subjected to compressive forces which produced the complicated system of folding and faulting that is so noticeable wherever the rocks are well exposed. This process was accompanied and followed by intrusions of igneous rocks, and the area was elevated high above sea level.

As soon as the land appeared above water, the agents of the atmosphere began their work of decomposition and disintegration, und the newly formed streams began to wear away the land surface and transport the products of weathering to the ocean, where the material was redeposited to form new beds of sediments. Denudation was continued until the region was beveled across hard and soft formations alike, and the country reduced to a condition bordering on base-level. Such a surface is known as a peneplain.

The area has undoubtedly experienced several periods of peneplaination followed by renewed elevation of the land surface, but it is unlikely that the Piedmont section as a whole has been depressed below sea level since Ordovician time.

Following a period of base-leveling, the surface was warped enough to allow the Newark beds to be laid down in long, narrow trough-like basins, but, since that time, degradation has continued. without intermuption. The earliest great peneplain of which evidence remains extended far beyond the limits of this small area, and has been called the Kittatinny peneplain. ${ }^{a}$ It probably dates from the Cretaceous period.

In many places in the Appalachian States peneplains of later date than the Kittatinny plain have been noted, and while it is possible that periods of subsequent base-leveling may have occurred in this section, they have not been identified, and it is improbable that more than one plain can be distinguished within the limits of this area.

It is impossible to accurately determine the thickness of the material removed during the ages in which this degradation of the land surface was going on, but certainly it is to be measured in thousands of feet. All of the changes outlined above took place gradually and covered a long period of time. While we can not even approximately estimate the length of this time as measured in years, it must have been very great even in comparison with the time which has since elapsed.

aWillis, Bailey, The Northern Appalachians, Physiography of the United States, p. 180. 
During the latter stages of peneplaination decomposition proceeded much faster than degradation; the products of rock decay accumulated more rapidly than they could be removed by the slow-moving streams, which had almost attained base-level, and a deep mantle of residual soil was gradually formed that completely covered the hard rocks below.

The appearance of the surface at that time was probably not very different from that of the lower Mississippi valley to-day. The land was flat and featureless and elevated but little above sea level. Willis Mountain was probably the only elevation within the limits of this area that stood above the monotonous level of the plain. The stubborn resistance to weathering offered by the rocks forming this mountain served to protect it from the complete reduction that had befallen the surrounding area, and left it standing as a solitary monadnock. The rivers meandered sluggishly over the land in wide curves, and there were no marked divides. The course of these streams is not known, but many conditions indicate that they possibly drained toward the west.

In this condition a very slight tilting of the land surface was sufficient to change the courses of the streams, or even cause then to flow in the opposite direction, and it was upon this surface that the new system of drainage represented by the present antecedent streams was inaugurated.

The new streams, assuming their positions while the rocks of varying hardness were still covered by a deep blanket of residual decay and alluvium, were not influenced by the structure of the underlying formatious, and therefore ran slowly in winding curves closely coincident with those that they now possess. The establishment of the new drainage, however, was shortly followed by a progressive elevation of the land which quickened the streams, and they began the work of deepening their channels.

After cutting through the soft overlying. material and exposing the fresh rock below, the larger streams continued the work of corrading their channels in the more resistant formations. As fast as renewed elevation of the land surface raised the hard beds athwart their course, the streams, confined to their channels and restrained from altering their courses by the deep valleys which they had excavated in the softer material, were forced to cut through hard and soft strata alike. It was in this way that the larger streams were superimposed upon the structure of the undecomposed underlying rocks.

The fact that the rivers have not been able to cut their channels in hard rocks as rapidly as in the softer formations, accounts for the rapids 
that frequently occur. The rapids in James River at Bremo Bluff furnish a good example. Here the river.flows across beds of hard quartzite which, dipping vertically, are interbedded with softer mica-garnet schists. Because of the greater resistance of the quartzite to erosive action, the river has not been able to cut its bed downward or to widen its channel in it as rapidly as in the softer rocks, and therefore the quartzite beds stand out as ledges from the bottom of the river and project from the sides of the valley in bold cliffs. (See fig. 2, and Pl. III.) At the bridge the valley is only 500 yards wide from bluff to bluff and there are practically no bottom lands, but at a distance of only one mile up or down the river, the valley is a mile or more in width, the river being bordered by broad, alluvial flats which at times of very high water may be completely flooded.

While the larger streams were able to deepen their valleys, even in the hardest rock, and continued to flow across the strike of the strata, the secondary streams were not strong enough to maintain their courses in opposition to the forces tending to divert them into conformity with the structure. As a result, these streams were gradually diverted to the areas of softer rock, and this adjustment was more readily brought about as the original direction of flow was more nearly parallel to the rock structure.

It was throngh this struggle between the eroding power of the streams and the slowly rising land surface that the existing surface configuration was developed.

At present the larger rivers of this area are, in some places, cutting their channels deeper, while at others, as evidenced by the large islands and wide areas of bottom lands, they have begun to deposit part of their burden. The valleys are slowly being widened, chiefly through the decomposition and disintegration of the rocks under atmospheric agencies.

The smaller streams have not yet cut down through the decomposed material to fresh rock, but the rate at which they are now cutting is probably in most cases greater than that of decomposition.

Evidence of the former position of the rivers is furnished by deposits of water-worn gravel, representing the remains of old river terraces, that are found at various places high above the present level of the river. One of these old river terraces, some 200 feet above the present river bed, is located near Stearnes on the north side of James River, where it can be traced up stream for a distance of about a mile.

A profile of James River shows a rather sharp change in the grade, where the river crosses from the sedimentary rocks to the granite, just . 
below. Bremo Bluff. ${ }^{a}$ From Lynchburg to this point, a distance of 80 miles, the river falls an average of 3.71 feet per mile, while flowing over the granite from this point to Lorraine, 12 miles above Richmond, which is a distance of 91 miles, the river falls only .606 feet per mile. In both cases the grade is fairly uniform. The change is too sharp to be accounted for by the natural increase in the grade of the stream with its distance from the mouth, and is probably due to the difference in the character of the formations. Another possible explanation is that the tilting of the peneplain has not been uniform, but this would hardly account for the localization of the change in grade at this particular point. There is no evidence of faulting, and the rock exposures along the bluffs are particularly good in this vicinity, so that it would probably show if present.

aSee Plate VI, opposite p. 94, Hydrography of Virginia, Bull. No. III, Geol. Survey of Virginia, 1006. 
CHAPTER IV.

\section{STRUCTURE AND METAMORPHISM.}

\section{INTRODUCTION.}

Previous descriptions have brought out the fact that the dominant rock formations occur in zones or belts extending in a northeast and southwest direction, and dipping at high angles, usually toward the east. Sedimentary rocks, from the manner of their formation, are necessarily laid down in nearly horizontal beds; but, in the region under consideration, the older rocks have been subjected to severe compressive stresses which have crumpled and squeezed the beds into close folds, mashing even the hardest rocks into schists and gneisses. 'The rocks have also been profoundly altered by the intrusion of large igneous masses. Subsequently erosion has gradually removed the overlying material, beveled off the edges of the upturned beds, and in places exposed the underlying igneous intrusives.

The lack of accurate knowledge concerning the structural relations of the rocks in the surrounding territory, and the scarcity of exposures, due to the great depth of residual rock decay, make it impossible to work out many of the-details of structure in the limited area considered in this report, but some of the more important features will be discussed below.

\section{STRUCTURAI FEATURES.}

\section{Folding.}

There are three well-defined belts of pre-Cambrian metamorphic rocks of sedimentary origin, which consist essentially of knotted schists and interbedded quartzites. The most easterly of these belts extends southwest from Shannon Hill to Stage Junction; the middle belt is exposed in the river bluft's near New Canton and extends in a northeast and soutliwest direction approximately parallel to the first; the third belt is located along the northwestern margin of the map (Pl. I) .between Palmyra and Strathmore. This areal distribution of the rocks is strongly suggestive of folding, and there are a number of facts which indicate that there is an anticlinal fold between the eastern and middle belts, and a synclinal fold between the middle and western belts.

In the eastern belt the rocks dip southeast at an average angle of $45^{\circ}$, in the central belt they stand nearly vertical, and in the western belt they. 
dip at an angle of $75^{\circ}$ to $80^{\circ}$ southeast. The central and western belts are separated by the long narrow area of Ordovician sediments, which were deposited unconformably upon the eroded surface of the older preCambrian rocks; the eastern belt is almost entirely cut off from the other rocks by the large areas of intrusive granite (see p. 102).

The crustal movements continued with less intensity after the deposition of the Ordovician sediments, and these beds were compressed into the synclinal fold to which they owe their preservation. The Ordovician slates are extensively faulted and crumpled into innumerable minor folds, but the synclinal nature of the belt is shown by the presence of a basal conglomerate along the contact with the older rocks on both sides. The close folding and faulting shown in the section along the south side of James River (see Pl. VII) indicates that the beds were probably of no great thickness, and that they could not have been folded under conditions of very deep burial. The lack of a well-developed slaty cleavage in slate - from the bottom of the synclinal trough has been commented on in a previous chapter (see pp. 45-46).

In the time that has elapsed since their deposition and subsequent folding, erosion has removed all of the Ordorician sediments except the long narrow belt of rocks, preserved in the bottom of the synclinal trough. Rivanna River has cut completely through this narrow remnant and exposed the underlying granite, thus proving the shallow character of the formation. In the railroad cut, half a mile south of Carysbrook, the Ordovician sediments are exposed resting on the eroded surface of granite (see Pl. VI, fig. 1), and as the river is approached the beds gradually thin out until they completely disappear. The slates are again exposed along the upper portion of Long Island Creek between Palmyra and Wilmington; and the creek, which in both its upper and lower portions is in direct alignment with the strike of the rocks in the tiwo areas, probably owes its position to the slate belt, now partly removed by erosion.

The small detached slate area, paralleling the main belt a short distance north of Fork Union station, probably represents a minor fold which has been separated from the main belt by erosion; and minor folding offers the most plausible explanation for the widening of the slate belt in the section along the south side of James River.

It is not unlikely that there are numerous subordinate folds superimposed on the major folds of the pre-Cambrian rocks, but the nearly isoclinal dip, together with the lack of exposures, makes it impossible to work out minor details of this character. The presence of these minor folds is occasionally. indicated by discordance between the bedding and schistosity - shown in Spec. 342 from the Buckingham mine.

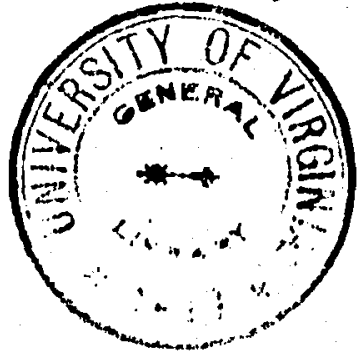




\section{Faulting.}

Small faults, ustally of the thrust type; are plentiful in the Ordovician slates and may be seen at many points in the bluffs along James River; they have also been detected in the pre-Cambrian rocks, and it is probable that many are concealed by the steep monoclinal dip of the bedding and schistosity. All the faults observed are approximately parallel to the strike of the rocks and it is unlikely that many of them cut across the structure. No large faults were definitely located along the boundaries between different formations although it is not improbable that such faults exist in a few places.

Some faulting has taken place in this region as recently as Triassic times, for a number of faults have been discovered in the Farmville aren (see p. 47), as well as in the other Triassic areas of Virginia. The displacement along these recent faults, however, is comparatively small and they do not seem to have affected the structure of the country in any important way. The occurrence, during the past few years, of several feeble earthquake shocks in the vicinity of Arvonia is possibly due to adjustments that are taking place along some of these fractures.

The determination of faults in the granites and related igneous rocks is a more: difficult problem, but the presence of cemented breccia on the Hughes farm, 21/2 miles west of. Tabscott, and on the Dickey farm, 2 miles southeast of Cremona, indicates that fracturing with more or less faulting has taken place at these points.

\section{Jointing.}

Joints are very plentiful in all portions of the area mapped, and, while they run in every conceivable direction, they show a decided preference for certain quarters of the compass. Joints having a general northeastsouthwest strike, approximately parallel to the schistosity, are most common and those with a northwest-southeast trend are second in importance. North-south and east-west strikes are comparatively rare.

As a general rule joints are more closely spaced in the rocks of sedimentary origin than in the more nearly massive and compact rocks of igneous origin. For example, in the railroad cut half a mile south of Carysbrook, where Ordovician sedimentaries are exposed resting on the eroded surface of the older granite, the principal directions of jointing are N. $25^{\circ} \mathrm{E}$., N. $60^{\circ} \mathrm{W}$., and parallel to the contact which dips southeast at an angle of less than $30^{\circ}$. In the granite the joints are spaced 2 to .4 feet, while in the slate they are only 2 to 8 inches apart. 


\section{Schistosity.}

Schistosity is that property of rocks which causes them to break most readily along certain parallel planes, and is due to mashing accompanied by more or less recrystallization of the mineral constituents. It is usually induced by the same compressive forces which result in folding and faulting, and is therefore parallel to the axes of the major folds.

With certain exceptions, noted later, the strike of schistosity throughout the region mapped, is northeast-southwest at slightly varying angles, and the dip is usually steeply inclined toward the southeast. In the preCambrian rocks of sedimentary origin the schistosity is almost always parallel to the strike and dip of the bedding; and the few exceptions to this rule which were noted are probably due to the presence of subordinate folds superimposed on the major folds. There are greater variations in the relation of schistosity to bedding in the Ordovician slates than in the older rocks, for these have not been subjected to such severe compression and the dip of the bedding is therefore less uniform.

On the Stage Junction road, a mile north of Columbia, there are a number of rock exposures in the vicinity of the contact between the intrusive granite and the older pre-Cambrian schists and quartzites. In these exposures the strike of the schistosity is approximately parallel to the contact, varying from $N .15^{\circ}$ to $24^{\circ}$ W., and dipping southwest at an angle of about $45^{\circ}$. This exception to the general trend of the schistosity affects both the sedimentary and the igneous rocks and is probably due to the intrusion of the latter.

In most places the boundary of the granite area runs in a general northeast-southwest direction, approximately parallel to the strike of the bedding and schistosity of the neighboring sedimentary rocks; and in the few places where the contact cuts across the strike of the latter, the exposures are not sufficient to determine whether the anomaly described above holds true in other localities or not.

A peculiar form of schistosity was observed in slate from the bottom of a synclinal fold (see pp. 45-46). Instead of the usual slaty cleavage it has a prismatic cleavage, which causes the rock to break with equal readiness in all directions parallel to the axis of folding, while it breaks with much greater difficulty at right angles to this axis.

The schistose structure possessed by most of the granites and related igneous rocks of the district, was probably induced by pressure or mashing of the massive rock, but the gneissoid banding shown in. certain localities (see Pl. VIII, fig. 1) is evidently a primary flow structure. In 
the Elk Hill complex (see p. 57) granite occurs in the form of inumerable dikes, varying from a few inches to 50 feet or more in width, which have been intruded into the hornblende schist; and while for the most part the granite follows the planes of schistosity in the older rock it occasionally cuts directly across. Some of the granite dikes have a much contorted gneissic banding; and since the contortions are not shared by the older schist, they can not be explained by pressure, and must be due to movements in the partly solidified granite.

\section{Structural Relations of the Granite.}

Granite is a rock which forms only under conditions of deep burial, and therefore a large amount of overlying material must have been removed by erosion in order to expose the present surface. There is nothing to indicate that the material removed was essentially different from the formations that remain in contact with the granite, and that certainly in places overlie it. From this it should not be inferred that these same sedimentary formations necessarily extended for an indefinite distance toward the east; but it is believed that they formerly covered the granite in the immediate vicinity of the contacts, and that they once covered the large areas, such as the one lying between Stage Junction and Fork Union, which are still partly or wholly surrounded.

The areal distribution of the two formations indicates that the contact between the granite and the pre-Cambrian sedimentaries is not a uniform plane, but that the granite rises higher along certain lines that probably represent anticlinal folds. Such a line connects the granite embayment heading near Wilmington with the area lying between Kent's Store and Tabscott, and there is evidence that the intervening region is underlaid with granite at no great depth. The sedimentary rocks in the region between these two granite areas are intensely metamorphosed, hornblende schists are common, and there are numerous intrusive bodies of porphyry and pegmatite. The latter, which are probably differentiates from the underlying granite, are limited to this particular region and do not occur in the schists on either side. Some of the facts indicating the presence of an anticlinal fold in this vicinity were given in a previous paragraph, and it is interesting to note that the gold veins are located chiefly in the limbs of these folds not far from the granite contact.

In the southern portion of the area mapped the exposure of granite at the Greeley mine, a mile southwest of Gravel Hill, is in direct line of strike with the Rosney granite area; and the sedimentary rocks lying 
between these two localities show evidence of contact metamoiphism. Some of the rocks, as at Tower Hill, are largely altered to garnet and sillimanite, and tourmaline-bearing quartz reins are plentiful. It is believed that granite closely approaches the surface along this northeast-southwest line, and that the few exposures which occur are located where erosion has removed the overlying cover of sedimentary rocks. It is probable that much of the pre-Cambrian sedimentary area is underlaid with granite at greater depths.

\section{Relations of the Hornblende Schists to the Granites.}

Fornblende schists are plentiful in the Columbia granite area and in the Ilk Fill complex, but are rarely found elsewhere in the area of granitic rocks; their distribution and occurrence have been described in detail in a previous chapter. There are two hypotheses that may be oftered in explanation of the presence of these schists: (1) They are due to the partial solution and recrystallization of inclusions of the country rock, and (2) they represent. segregations from the original granite magma. No cliemical analyses are available, but all of the field and petrographic evidence is in favor of the latter hypothesis.

One of the chief objections to the first hypothesis is that, while the schists are-more-plentiful near the boundary of the granite area, there is no noticeable variation in their abundance or in their mineral composition consequent upon changes in the character of the sedimentary rocks along the contact. Moreover, they are abundant in the Elk Hill complex, which is situated far from the contact with sedimentary rocks. Another serious objection is the fact that the central portions of even the largest hornblende areas show no evidence of a sedimentary origin.

On the other hand, the areas of homblende, schiste vary in abundance and size with the mineral composition of the granite; they are most plentiful in the southern portion of the Columbia area where ferromagnesian minerals, especially hornblende, are abundant in the granite, and they are absent in the embayment between Wilmington and Carysbrook, where the ferromagnesian minerals are at a minimum. 'The reasons for' believing that the granite near Carysbrook solidified later than the rock in other portions of the area were given on pages $62-63$, and the field evidence is conclusive in showing that the hornblende schists crystallized prior to the complete solidification of the associated granite.

The hornblende schists are remarkably uniform in mineral composition, and the variations from the normal are all intermediate between the 
granite and the typical schist. Occurrences showing a gradation of granite into hornblende schist were described in detail in a previous chapter (see - pp. 66-68). On approaching a large area of hornblende schist the potash feldspars and muscovite disappear from the granite and finally hornblende gradually takes the place of biotite.

It seems probable that the hornblende schist and granite of the Elk Hill complex belong to the same period of intrusion as the rocks of the Columbia area, for they are similar in appearance and mineral composition. Another fact, which lends support to this supposition, is the absence of hornblende schists along the contact between the Columbia area and the pegmatite belt, although the schists commonly constitute a border facies of the granite. This suggests that the Elk Hill complex may represent the real eastern border of the Columbia granite and that the intervening pegmatites may be residunl differentintes from a common magma.

As yet little is known of the processes by which rock magmas are differentiated into rocks differing widely in mineral and chemical composition. In the absence of numerous chemical analyses of the rocks it is impossible to discuss the various theories of rock differentiation and their application to the present problem; but some of the more important facts concerning the differentiation of the hornblende schists will be summarized, and the próbable processes will be briefly outlined.

'The hornblende schists crystallized prior to the granites with which they are associated, and they are more plentiful where the granite is hornblende-bearing. In the Columbia area the hornblendic granites probably solidified prior to the granites containing little or no hornblende. Where hornblende occurs in the granites it is one of the minerals of early crystallization. The bodies of schist vary in size from small schlieren up to areas that are over a square mile in extent, and they are most abundant in the marginal portions of the granite area.

'The hypothesis outlined below, while only tentative in its nature, is based on the facts given in the previous descriptions, and serves to explain the observed relations between the hornblende schists and the associated granite. As the original magma gradually cooled, crystallization began in the border portions where the temperature was lowest, the more basic minerals separated out first; and in this way the marginal areas of hornblende rock were formed. - Differential movements, occurring after the basic border facies of the magma had partly or wholly crystallized, resulted locally in the intrusion of the still-fluid portions of the magma into the 
solidified rock, and caused the interleaving of the two rock types that is such a prominent feature of the Elk. Hill complex. The detached areas of hornblende schist found within the central portion of the granite may represent material derived from the border portions, or possibly they are due to segregations in situ.

The differential movements mentioned above may have brought portions of the solidified rock into contact with magma having a higher temperature and resulted in some resolution. This possibly explains the occurrence of intermediate rock types with unusual coarse textures, for when recrystallization followed upon partial solution any undissolved crystals would prevent supersaturation, which is commonly the cause of rapid crystallization and fine texture.

It is believed that the granite near Carysbrook, which is low in ferromagnesian minerals and contains no marginal areas of hornblende schist, was intruded in a partly crystallized condition (see pp. 62-63), and was the final portion of the magma to solidify.

\section{METAMORPHIC FEATURES.}

\section{Regional Metamorphism.}

All the older rocks in the area studied, both those that are sedimentary and those that are igneous in origin, have been deeply buried in the anamorphic zone, and most of them show pronounced effects of dynamic metamorphism. Megascopically these effects are manifested chiefly by the development of a schistose structure, which in some instances is accompanied by gneissoid banding. In a rough way the degree of alteration is proportional to the age of the rocks; the pre-Cambrian sediments are the most -schistose, the Ordovician rocks show less effects, and the Triassic rocks are practically unaltered. The degree of schistosity is also dependent on the composition and original texture of the rock. The pre-Cambrian quartzites, for example, are almost massive, while the fine-grained schists with which they are interbedded have a highly developed cleavage and almost perfect parallel orientation of the mineral constituents.

Microscopically, the chief evidence of dynamic metamorphism is furnished by the fracturing, granulation, and optical distortion of certain minerals, by recrystallization, and by the complete or partial alteration of primary to secondary minerals, such as sericite and chlorite.

The development of the pseudophenocrysts that occur in the knotted schists took place under mass-static conditions, for these minerals are of later formation and show no regular orientation. relative to the schistosity
of the rock. 
Since the metamorphism of the different rock types has already been considered in the chapter on descriptive geology and petrography, a detailed discussion will not be given here. While the alterations outlined above have been attributed chiefly to mass-mechanical action under conditions of deep burial, it is probable that the changes have been greatly aided by the intrusion of the vast masses of igneous rock, only part of which have been exposed by erosion.

\section{Contact Metamorphism.}

\section{INTRODUCTION.}

Under contact metamorphism, those changes will be discussed which are set in action by intrusive masses of molten rock. The metamorphism of the wall rock is manifested by recrystallization, usually with the production of new and characteristic minerals, and by clinges in texture; the effects are at a maximum near the intrusive and decrease in intensity with the distance from the contact: The intrusive likewise shows more or less variation in texture and mineral composition as the contact is approached.

It is now generally believed that the changes which take place in the vicinity of igneous intrusives are due chiefly to the action of highly heated water and other mineralizers set free by the solidifying magma. These highly heated rapors or gases, probably carrying a certain amount of silicates and other substances in solution, penetrate the surrounding rock through minute fractures and pores, bring about the formation of new minerals, and deposit their dissolved material. Acid magmas, such as those from which granites crystallize, are supposed to be richly provided with these mineralizers, and therefore commonly produce greater effects than more basic magmas.

All the older. rocks in the Tames River basin have been subjected to intense dynamic metamorphism and it is often difficult to distinguish between alterations due to this cause and those due solely to igneous intrusives. The diabase clikes, and other small masses of intrusive igneous rock, have produced practically no effect on the sedimentary rocks along their contacts, but in the vicinity of the granite area the older rocks have been intensely altered by contact action. Because of the lack of good exposures, there are only a few places where the contact between the granite and the sedimentary rocks can be observed and studied; the best of these is furnished by the bluffs along James River and Phelps Creek in the vicinity of New Canton. The rocks in this locality will now be described in detail. 


\section{DETAILED DESORIPTIONS OF CONTACT PHENOMIENA.}

\section{James River Section Across Granite Contact.}

On the south side of James River near New Canton, the contact between the granite and the pre-Cambrian sediments is marked by a belt of hornblende schists, 800 to 900 yards wide, part of which are sedimentary in origin, while part represent a basic border facies of the granite. In the absence of chemical analyses it is impossible in many cases to distinguish between the rocks that are igneous and those that are sedimentary in origin, and indeed they are to a certain extent interleaved with one another; therefore the line drawn on the map (Fig. 2) to show the contact between the two formations is only approximate. On the east side, the hornblende schists pass into granite, while on the west they grade into the knotted schists which are interbedded with quartzites.

'The quartzites are described in detail on pages 16-18, and the knotted schists on pages 30-34. At a distance from the contact the knots or eyes present in the schist consist of impure siderite; about 900 yards east of the hornblende schists, biotite begins to take the place of siderite in the eyes, and within 600 yards of the hornblende schists garnets appear. The change is one of gradual increasing intensity of metamorphism as the contact is approached; but there is one exception to this rule-the knotted schists occurring along the east side of the quartzite, about 700 yards from the hornblende schists, are intensely altered in the immediate vicinity of their contact with the quartzite, probably because the latter rock, being more porous, has furnished a channel for the circulation of the heated solutions expelled from the cooling granite.

About 300 yards southeast of Bremo bridge, an old tunnel, said to have been opened in prospecting for iron, exposes the rock along the east side of the quartzite. Near the schist the quartzite contains numerous garnets, and the quartz appears to be completely recrystallized. Adjoining the quartzite there is a bed of highly garnetiferous rock, 4 to 12 feet wide, which grades into the typical knotted schists. The strike of the schists is $\mathrm{N} .23^{\circ}$. E. and the dip practically vertical.

'The altered rock (Spec. 456) near the quartzite is dark gray to brown in color, and consists of numerous red garnets, ranging up to $4 \mathrm{~mm}$. in diameter, fine-grained quartz, radiating crystals of dark gray sillimanite, and a little dark green chlorite. Examined in thin sections under the microscope the garnets are light pink to nearly colorless, contain numerous inclusions, are irregular in outline, and show partial alteration to chlorite 
in their border portions and along fractures. Some are quite clear while others are rendered almost opaque by clouds of dust-like inclusions (magnetite or hematite), which are frequently confined to the central portions leaving the borders clear. Some of the garnets also contain numerous included quartz grains. Quartz, which is the second mineral in relative abundance, has been completely recrystallized and occurs in irregular grains showing strain shadows. The sillimanite is mostly arranged in radiating clusters of prismatic crystals. Magnetite, hematite, and a little pyrite are present as minor accessories.

Other exposures are furnished by several surface pits located along the same line of strike, a mile southwest of New Canton; and here the garnet rock may be seen grading on the east into the knotted schists containing scattered eyes of garnet. The rock (Specs. 465 and 466) from these openings is dark reddish-brown in color and consists chiefly of garnets with less quartz, sillimanite, cyanite, chlorite, magnetite, hematite, and pyrite present in the order named. The garnets (almandite) are large, imperfectly formed, and contain numerous inclusions of quartz and iron oxide. Under the microscope they frequently show irregular branching radii of clear mineral which spread out from the center and separate areas that are full of inclusions. As these radii recede from the center they branch into/a vein-like network, which grades without definite boundaries into the surrounding ground-mass, consisting of quartz, garnet, and magnetite. Another form of garnet (possibly spessartite) is so full of dust-like inclusions of magnetite with a little quartz, that they are rendered almost opaque. These inclusions show a zonal arrangement, and in some of the garnets the zonal bands are broken and contorted as though by crushing. Sillimanite is present in radiating groups of fine-bladed crystals, and cyanite occurs in large-bladed prisms, which frequently show multiple twinning and contain dust-like inclusions of iron oxide.

A garnet-sillimanite rock, similar to that just described, outcrops along the road near Hatcher Creek, a mile south of Gravel Hill postoffice, and also near the summit of Tower Hill, $21 / 2$ miles southwest of Gravel Hill.

Passing eastward from the quartzite, knotted schists are exposed in the river bluffs for several hundred yards. Specimen 30\%, taken from an outcrop 200 yards east of the quartzite and 800 yards from the contact, contains numerous eyes of biotite and only occasionally a small garnet. A detailed petrographic description of the rock is given on pages 32-33. About 300 yards farther east the schist (Spec. 306) is light bluish-gray in color, slightly coarser grained, and contains scattered eyes of garnet 1 to $2 \mathrm{~mm}$. 
in diameter. Specimen 305, taken about 400 yards from the contact, is of light gray sericitic schist containing garnets 2 to $4 \mathrm{~mm}$, in diameter, and occasional flakes of biotite about $1 \mathrm{~mm}$. in diameter.

Near Phelps Creek and about 300 yards from the contact hornblende begins to be plentiful in the schist, occurring in dark green crystals that range from small grains up to prisms 3 or $4 \mathrm{~mm}$. in length. The rock (Specs. 303 and 304) is mostly fine-grained and compact, breaking readily along closely spaced joints. The minerals distinguishable megascopically are quartz, hornblende, chlorite, sericite, much pyrite, and a little magnetite. The New Canton copper mines are located directly in line of strike with these rocks and therefore the large amount of pyrite present is significant. Petrographic descriptions of rocks from the different copper mines are given on pages $250-256$.

Near the second railroad bridge over Phelps Creek and about. 250 yards from the contact the schist. (Spec. 301) is a fine-grained, dark greenish-gray rock, speckled with numerous, well-formed, red garnets $0.5 \mathrm{~mm}$. in diameter, and containing occasional lenses of pyrite 2 or $3 \mathrm{~cm}$. in length. With the aid of a pocket lens small needles of hornblende, oriented parallel to the schistosity, and fine-grained quartz are seen to make up the greater part of the rock-mass. At the Margaret mine and about the-same distance from the contact a quartzitic rock was found which contains irregular crystals of dark green hornblende and light greenish-brown needles of sillimanite.

In the bluff on the east side of Phelps Creek, and about 150 yards from the contact line shown on the map (Fig. 2), an apophysis or dike from the granite is exposed. It is perhaps 20 feet in width and parallels the inclosing schists in strike and dip. The rock (Spec. 426) is light gray in color, fine-grained, and highly schistose; it is composed essentially of white feldspar, quartz, and flakes of black biotite, which are oriented parallel to the schistosity and are much more plentiful in some partions of the rock than in others. A little garnet and magnetite may also be distinguished megascopically. Examined microscopically the rock is seen to be slightly porphyritic in texture, containing feldspars that range up to $2 \mathrm{~mm}$. in length. The feldspars are all plagioclase (albite-oligoclase or oligoclase) and are for the most part unstriated, but occasionally both Carlsbad and albite twinning can be distinguished. The biotite is light greenish-brown in color, strongly pleochroic, and some of the flakes are nearly as large as the feldspars. The ground-mass is composed of feldspar, quartz, biotite, a little chlorite, small pink garnets, and a few grains of magnetite and irregular zircons. 
Along the contact between the granite dike and the hornblende schists there is a layer of rock (Spec. 42\%), only a few inches thick, composed largely of bright green chlorite and well-formed garnets ranging up to $0.75 \mathrm{~cm}$. in diameter. Under the microscope the garnets are seen to contain numerous inclusions of quartz and magnetite. None of the chlorite is derived from the garnets, for the latter are all fresh and unaltered. Quartz occurs in lenticular eyes and as small veinlets between the cleavage planes of the chlorite. Fluid inclusions, usually with bubbles, are plentiful and some are comparatively large. Scattered grains of magnetite and a little sericite make up the accessories.

About 50 yards southeast of the granite dike and within 100 yards of contact line shown on the map, the rock (Spec. 428) is light gray, fine-grained, close-textured, and distinctly schistose. It contains wellformed pink garnets ranging up to $2 \mathrm{~mm}$. in diameter, and with the aid of a pocket lens small needles of green hornblende, quartz, and much finegrained magnetite may be distinguished.

Under the microscope the magnetite is seen to occur in idiomorphic grains which are scattered through the rock without reference to the other minerals; the hornblende occurs in slender needle-like prisms, occasionally showing sections with crystal outline; and the quartz is present in irregular gr'nins filling the interstices between the other minerals. Scattered through this ground-mass there are a few comparatively large irregular crystals of acid plagioclase feldspar, ranging up to $2 \mathrm{~mm}$. in diameter. They are very ragged in outline and poikilitic in texture containing numerous small inclusions of quartz and to a lesser extent of the other minerals. The hornblende needles occasionally project into the feldspars, but are usually pushed aside by them. The feldspars are partly oriented with their greater elongations parallel to the schistosity, they rarely show fine albite twinning, and are usually unstriated. A little chlorite is present as an alteration product of hornblende.

The rock (Spec. 429) 30 yards south of that last described is dark green, even-granular, and more nearly massive in texture. Under the microscope it is seen to consist of hornblende, feldspar, quartz, and a little magnetite and pyrite, in the order named. Hornblende, which is dominant. occurs in irregular, elongated prisms only partly oriented parallel to the schistosity. The feldspar is all acid plagioclase with an index of refraction approximately the same as quartz, and is partly unstriated and partly twinned after the albite law. A small amount of chlorite is present as a secondary mineral. In the absence of chemical analyses it is impossible to say whether the rock is sedimentary or igneous in origin. 
The rocks exposed in the bluffs along the east side of Phelps Creek as far south as the county road are all hornblende schists varying slightly in coarseness of texture. In places narrow dikes of quartz porphyry containing much biotite are interleaved with the homblende schists.

About 60 yards northeast of the road bridge, and within 50 yards of the contact as shown on the map, the rock (Spec. 433) is dark green, fine-grained, close-textured, and contains much pyrite in scattered cubes, ranging up to $3 \mathrm{~mm}$. in diameter. Examined microscopically the rock is seen to consist of quartz, hornblende, magnetite, a little plagioclase feldspar, and some secondary chlorite. The magnetite is present in idiomorphic grains evenly distributed through the rock; the hornblende is almost as plentiful as the quartz, occurring in needle-like prisms that are imperfectly oriented parallel to the schistosity; and the quartz fills the interstices between the other minerals and occasionally forms lenticular eyes, $1 \mathrm{~mm}$. in diameter. Both hornblende and magnetite are present as inclusions in the quartz. A little acid plagioclase showing albite twinning may be identified in places but is not plentiful.

Specimen 434 was obtained from the bluffs facing the low ground on the south side of James River and about 75 yards east of the line of contact as shown on the map (Fig. 2). The rock is a dark gray, fine-grained hornblende-schist containing streaks due to elongated segregations of the light-colored minerals. . It is cut by closely spaced joints, which cause the rock to break into small rhombic shapes. Examined under the microscope, hornblende is seen to be dominant, occurring in slender prisms which occasionally show idiomorphic cross sections and are usually orjented parallel to the schistosity. They show good cleavage and are practically free from inclusions. The interstitial spaces are filled with acid plagioclase, quartz, and magnetite. The feldspars are clear, seldom show cleavage or twinning, and have an index of refraction slightly less than balsam, corresponding to albite or albite-oligoclase. Quartz is present as a minor constituent, magnetite occurs in small scattered grains, and there is a little chlorite present as an alteration product of hornblende.

A hundred yards farther east-the hornblende schist (Spec. 435) is much coarser in texture. It is a heavy rock, dark green to black in color, and contains hornblendes ranging up to $6 \mathrm{~mm}$. in diameter, numerous grains of magnetite, and occasional light-colored spots, consisting of finegrained, light green epidote. Under the microscope the hornblende, which makes up the greater portion of the rock, is strongly pleochroic in shades of dark green, blue, and greenish-brown; it has good cleavage but poor 
crystal form, and frequently contains numerous inclusions of quartz and magnetite. Magnetite is the second mineral in relative abundance, occurring in small angular grains and in larger masses which occasionally contrin inclusions of hornblende. Epidote is present in small grains and granulnr aggregates, almost colorless and only slightly pleochroic. Quartz is sparingly present in small grains and chlorite occurs as an alteration product of hornblende.

Fine-grained hornblende schist, over 100 yards in width, intervenes - between the coarse-grained schist and the granite, which first appears about 400 yards east of the line showing the approximate contact between the sedimentary and igneous rocks. In the road half a mile south of $\mathrm{New}$ Canton a coarse-grained hornblende schist, contrining a much larger percentage of feldspar than the rock described above, is exposed close to the granite.

The granite (Spec. 438), exposed in the river bluffs near the hornblende schists, is dark gray, fine-grained, and very gneissic in structure. The minerals recognizable megascopically are feldspar, quartz, biotite, many small pink garnets, and a few scattered grains of hornblende and magnetite. A specimen (439) obtained about 200 yards farther east is much lighter in color. It has well-developed gneissic banding, and sericite - is rery prominent, while biotite is relatively scarce. Examined microscopically it is seen to consist of acid plagioclase, quartz, sericite; biotite, garnet, a very little hornblende, and the secondary minerals epidote and chlorite. There seems to be no potash feldspar present. Other specimens of the granite from this vicinity are described on pages 71-72.

On the opposite side of James River the marginal belt of hornblende schist is narrower, but there are several small elongated areas of hornblende schist included within the granite. Continuing northeast along the contact the belt of hornblende schists gradually becomes narrower and a short distance south of Fork Union entirely disappears.

\section{Rivana River Seotion Aoross Granite Contact.}

The contact between the granite and the sedimentary rocks is fairly well exposed in the bluffs on the sonth side of Rivanna River, a mile northwest of Carysbrook. A quarry has been opened in the granite within less than 100 yards of the contact, and the rock exposed in the opening is described in detail on pages 75-7\%. The contact can be located with an error of less than 20 feet, but there is little if any evidence of contact metamorphism. The granite is probably a little finer grained than that 
exposed in the quarry, and contains more pyrite. The sedimentary rock is a chloritic slate which near the contact is slightly, coarser grained, more siliceous, and less regular in its cleavage, but all of these differences may be due to other causes than contact metamorphism.

No evidence of faulting is visible, and the textural and structural relations of the slate indicate that it is older than the granite. The lack of pronounced evidence of contact action is probably due to the fact that the sedimentary rocks were intensely altered by dynamic metnmorphism, prior to the intrusion of the granite, which must have been much cooler than the granite near New Canton. On pages 62-63 evidence was presented to show that the granite near Carysbrook was intruded and solidified nt a later date than the granite farther south; and both the megascopic and microscopic evidence (see $\mathrm{pp}$. 75-76) indicates that this granite was intruded in a partly solidified condition.

\section{VEINS.}

Quartz veins are of frequent occurrence in the sedimentary rocks near their contacts with the granite, and, where not exposed, their presence is commonly indicated by an abundance of quartz float on the surface. Nortl of James:River these veins contain soda-lime feldspars, muscovite, a little tourmaline and other minerals indicative of a magmatic origin, and they usually carry small quantities of gold; south of the river tourmaline is very abundant in many of the quartz veins. Some of the veins are accompanied by more or less metasomatic replacement of the wall rock, and an extreme example of this replacement is furnished by the sulphide bodies near New Canton. The walls of some of the veins show evidence of metnmorphic action similar to that found near the granite contacts, but on a smaller scale. The gold-bearing veins are described in detail in cluapter $\mathrm{V}$.

\section{Willis Mountain.}

On the southwest slope of Round Mountain (the southern knob of Willis Mountain) the schists in the vicinity of an intrusive diorite show pronounced effects of contract action. The exposures are limited to two shafts 40 to 50 feet deep, located about 100 yards apart in an east and west direction, which were sunk in prospecting for copper. The size of the diorite body could not be ascertained because of the insufficiency of exposures, but the coarseness of texture indicates that it is probably large.

Megascopically the diorite (Spec. 390) is a massive dark gray rock composed essentially of dark green hornblende in irregular. prismatic 
crystnls ranging up to $1.5 \mathrm{~cm}$. in length, white feldspars, which frequently show multiple twinning, numerous red gamets about $1 \mathrm{~mm}$. in diameter; with more or less pyrite and pyrrhotite. In places the rock is cut by narrow intersecting veinlets, some of which are composed of white feldspars, 2 to $3 \mathrm{~cm}$. in diameter, with more or less pyrite and pyrrhotite, while others consist chiefly of white, even-granular calcite. 'The latter range up to 6 or 7 inches in thickness. There are also occasional streaks or bands due to the presence of unusual amounts of garnet, or, more rarely, epidote.

Examined microscopically the hornblejdes gre light green in color and. contain numerous inclusions, principally feldspar and quartz. The feldspars show beautiful twinning after the albite and pericline laws, and in composition. are probably intermediate between andesine and labradorite. Most of the garnets show good crystal form; they are slightly. altered along fractures with the production of chlorite and calcite. A little light brown biotite, elongated grains of rutile, ilmenite partly altered to leucoxene, and occasional zircons make up the minor accessories.

The typical cyanite and quartz-sericite schists constituting Willis Mountain have been described in a previous chapter (see pages 25 and 27-28). The schist (Spec. 389) near the diorite is a light brown, fine-grained rock, heavily impregnated with pyrite in cubical crystals ranging up to 2 or 3 $\mathrm{mim}$. in dinineter. The other minerals recognizable megascopically are light brown biotite, a scaly micaceous mineral, colorless to light gray or green (probably chlorite), a few prismatic grains of rutile, and a little nearly colorless cyanite.

Under the microscope the light-colored mineral (chlorite), which is probably dominant, has very low interference colors and frequently occur's in radiating scales. The biotite is very light brown in color and rather weakly pleochroic; in places it contains needle-like prisms of rutile. Soda-lime feldspar, intermediate between andesine and labradorite, is the third mineral in relative abundance and frequently shows twinning after both the albite and pericline laws. Cyanite is quite plentiful, rutile is abundant in prismatic crystals and irregular grains, and there is also much calcite present. The crystals of pyrite contain occasional inclusions of rutile but no other minerals. Zircons are present as unimportant minor constituents.

\section{OUTLINE OF GEOLOGICAL HISTORY.}

The complete geological history of this region can not be written until the rocks of the Piedmont province have been studied and mapped in greater detail; the record is fragmentary and complex, and much of it: 
may never be deciphered. In the older rocks of the area, which have been classified as pre-Cambrian, no fossils have been found, and if they were ever present, they have probably been destroyed by the extensive metamorphism that has affected the entire region.

\section{Pre-Cambrian.}

The history of the James River.basin in pre-Cambrian times is slrouded in much doubt. It is not known whether the period of igneous activity, resulting in the formation of the basic rocks of the greenstone aren, preceded or followed the deposition of the pre-Cambrian sediments. These sediments were laid down as sand and mud in shallow waters not far from the shore, as is indicated by the lenticular shape and sudden pinching of many of the quartzite beds, as well as their frequent repetition. The formation of pure quartz sands involves the complete decomposition of quartzbearing rocks in order that the quartz grains may be separated from the other constituents, the latter going to form the fine clayey beds. Therefore most of the sediments were probably derived from a low-lying land area mantled with residual decay. These conditions, however, did not continue uniformly throughout the entire period of sedimentation, for the arkosic beds lying between Lantana and Pryors Crossronds were laid down under conaitions that did not permit mature weathering.

After their deposition the sedimentary beds were compressed by powerful forces acting in a northwest-southeast direction; the efiects of which were close folding, faulting, mashing, and recrystallization. These great crustal movements, which brought the pre-Cambrian period to a close, converted a large area within the limits of the North American continent into land. While the crustal morements were still in progress, and probably as another manifestation of the same orogenic forces, large masses of molten rock were intruded into the sedimentary formations.

\section{Cambrian.}

The period of igneous activity, which resulted in the intrusion and differentiation of the granites and their related rocks; continued until after the great crustal morements had ceased. The formation of the gold veins is believed to represent the final stage in the differentiation and crystallization of the granite magma.

The massive diorite dikes, which occur at several places in the area, were probably intruded during Cambrian times, but after this there ensued a long period of freedom from igneous activity. 
During Cambrian and early Ordovicinn time the area was subjected to extensive denudation, the products of erosion probably going to build up the Cambrian formations to the west. This period of denudation resulted in the removal of thousands of feet of overlying material and the exposure of the deep-seated granite.

\section{Ordovician.}

In late Ordovician time portions of the Piedmont region were again depressed below sea level to receive the sediments of that period, but it is improbable that all of the area has been under water since its elevation at the close of the pre-Cambrian. The Ordovician sediments were laid down on the eroded surface of the older formations, the material being derived from the neighboring land areas of pre-Cambrian rocks. The limited thickness of the coarser sediments at the base of the series, in comparison with the overlying beds of slate, indicates that subsidence was rather rapid; and the presence of tuffaceous becls shows that the movement was accompanied by more or less volcanic activity, although there are probably no igneous rocks of this age present in the district.

The Ordovician period was closed by marked geographical changes which enlarged the land areas and raised the recently formed sedimentary beds above wintei! After the close of the crustal movements resulting in the folding and faulting of the Arronia slate belt, the region seems to have entered upon a period of quiescence. While oscillations occurred in other parts of the country, the Piedmont portion of Virginin seems to have remained above water and to have suffered little if any deformation until after the close of the Carboniferous; and during this entire period peneplaination continued uninterrupted.

\section{Triassic. ,}

It seems probable that the Piedmont peneplain was but slightly affecter by the Appalachian revolution. The surface was warped or faulted sufficiently to form the elongated trough-like depressions, roughly parallel to. the coast, in which the sedimentary beds of the Trinssic (Newark formation) were laid down. It is not believed that these deposits ever covered a large area, though it is possible and perhaps probable that the detached areas found in Piedmont V.irginia were once connected with one another. The prevailing red color of the formations, the presence of coal beds, and the character of the fossils indicate that the sediments were deposited in fresh or brackish water and that they are not of marine origin. The 
material composing these strata was derived principally from the residual decay of the neighboring crystalline rocks, which must have undergone extensive chemical decomposition after they had been reduced by erosion to a nearly level plain.

The deposition of the Triassic sediments was accompanied or immediately followed by the intrusion of the diabnse dikes, which are of frequent occurrence throughout the Piedmont area.

Since Triassic time the surface has been slightly elevated, and there has been a little faulting, but no important crustal movements have occurred; degradation has continued without interruption down to the present day. The detailed history of the development of the existing surface features is given in the chapter on physiography. 


\section{CHAPTTER V. THE GOLD MINES OF THE DISTRICT. INTRODUCTION.}

Detailed descriptions of all gold mines in the district are given below, but because of lack of information some of the descriptions are not nearly so complete as others. When the region was studied by the writer most of the mines had long been abandoned and consequently few openings were accessible; development work was in progress at the Scotia, Tellurium, Waller, and Young American mines; an old shaft was being reopened on the Payne property; and a little ore had recently been mined from superficial workings on the Bowles tract. Some of the older mines have been described from time to time by geologists and mining engineers, and wherever information could be obtained from such sources it has been freely used. The mines on the north side of James River, in Goochland and Fluvanna counties, will be considered first, and then those located on the soutly' side of the river in Buckingham County.

\section{MINES IN GOOCHLAND AND FLUVANNA COUNTIES.}

\section{The Young American Mine.}

Location.-The Young American gold mine is situated in Goochland County about $11 / 2$ miles north of Lantana and $61 / 2$ miles northeast of Columbia.

History.-The Young American, formerly known as the Gilmer mine, is said to have been discovered about 1869 by a Mr. Aldrich, who at that time was operating a saw mill on the property. After a little prospecting he sank a shallow shaft on a vein, now known as the "House" vein, and then built a small stamp mill to crush the ore. The mill had wooden stamp-stems with iron shoes, and was operated by the same engine that furnished power for the saw mill. Mr. Aldrich is reported to have made some money from the mine, but only worked it for a short time. Later gold was discovered in the branch that runs through the property and sluice and rocker washing was carried on during the period between 1871 and 1874 . 



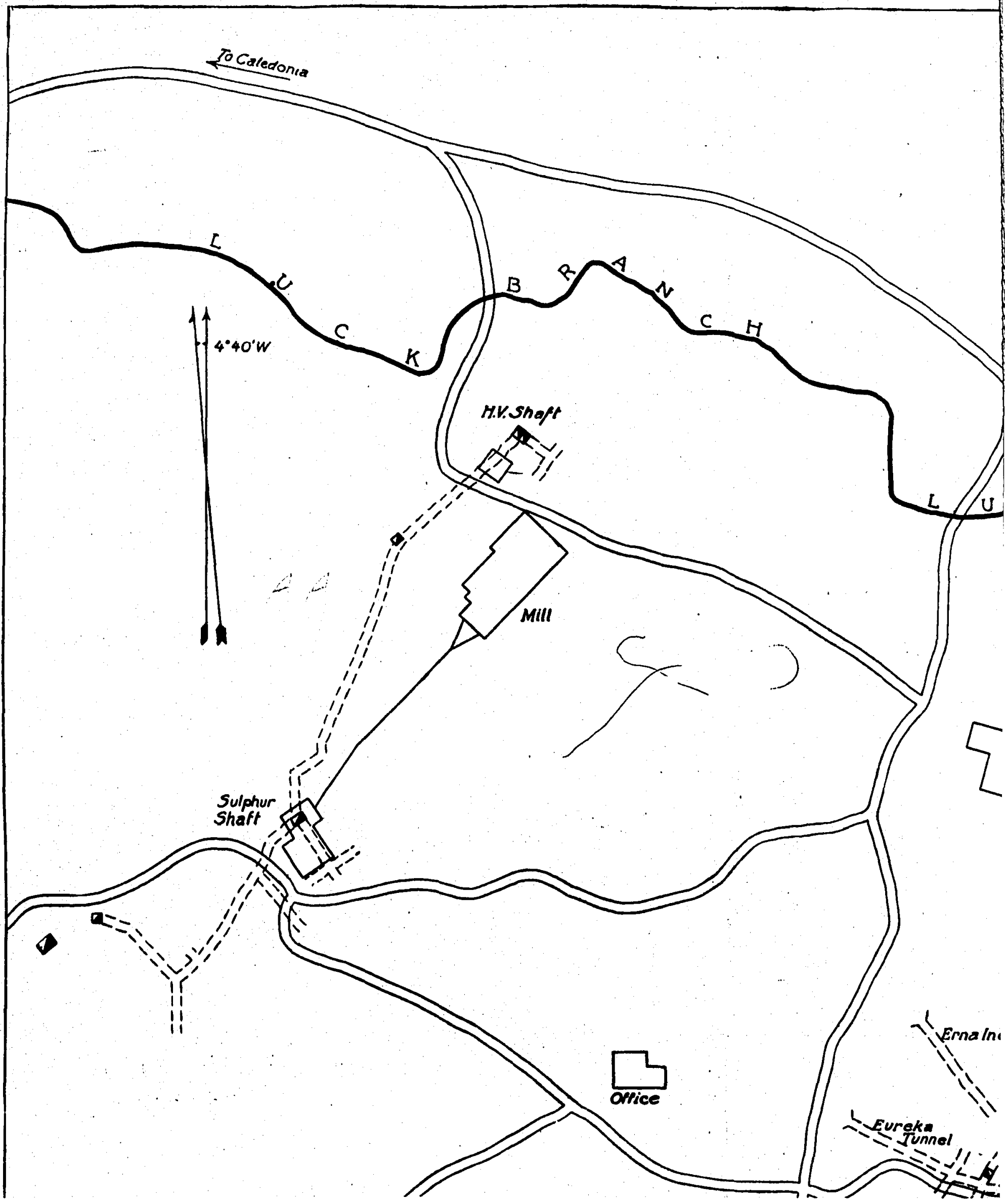




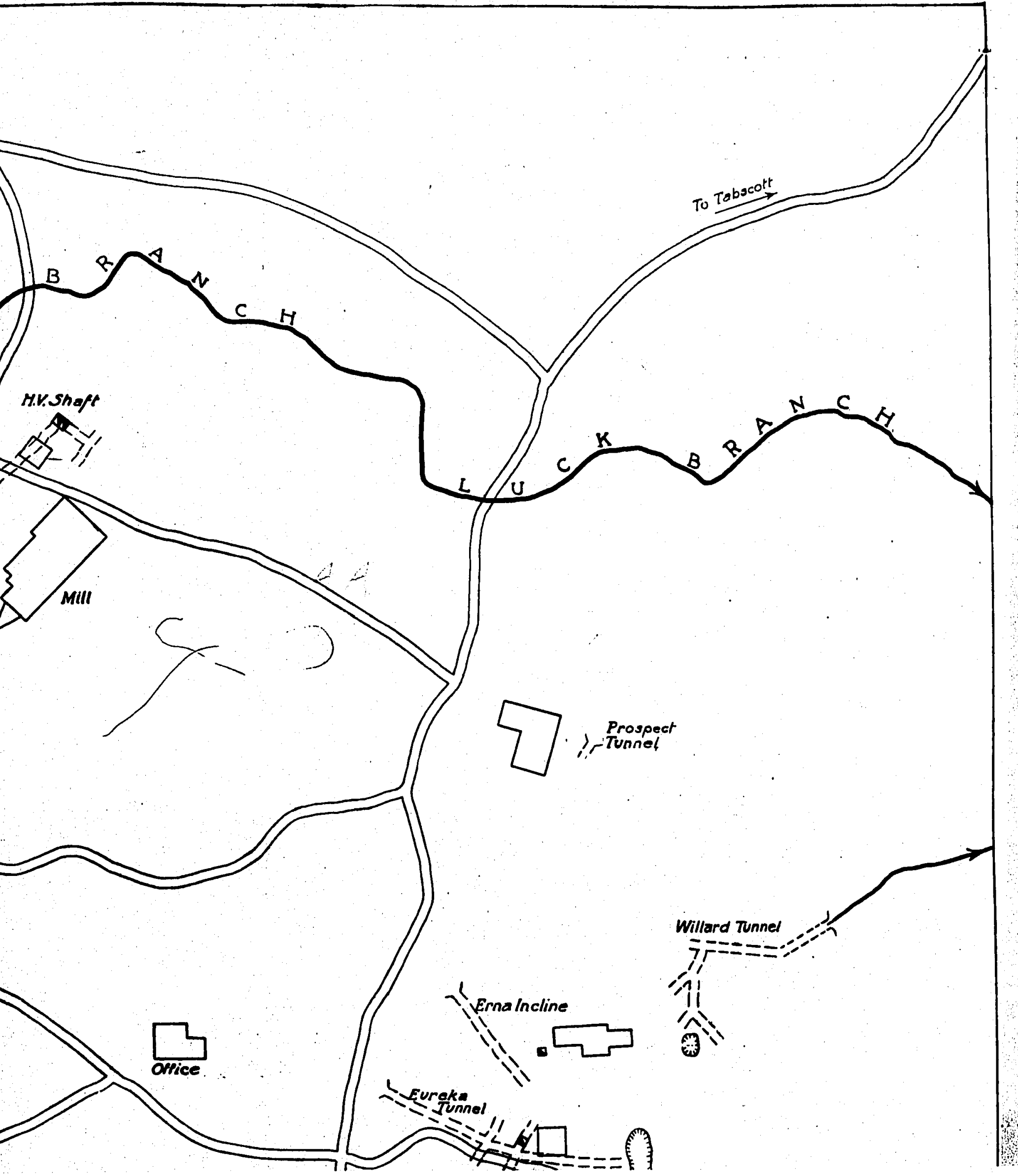




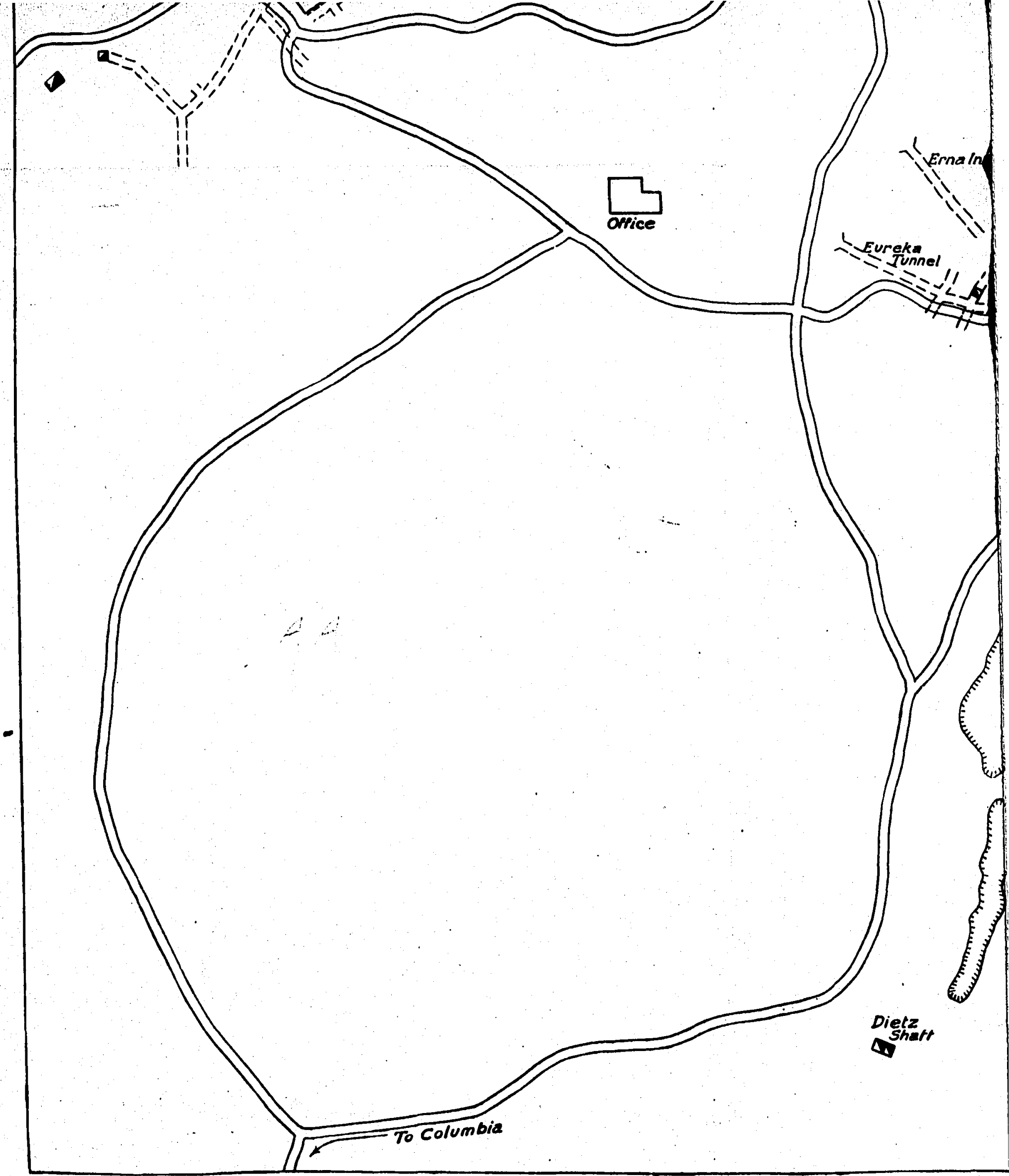

MAP OF SURFACE AND UNDERGROUND WORKINGS OF YOUNG AMERICAN 

In 1880, the Tagus Gold Mining Company began development work and continued operations for three years. About 100 tons of ore found on the surface were hauled to the Belzoro mill and stamped, yielding a return of $\$ 5.00$ per ton. The "House" vein was developed and stoped down to water level for a distance of approximately 600 feet along the strike, and some small lenses of quartz, paralleling the "House" vein about 100 feet to the west, were exposed by an adit and mined. The "Sulphur" vein, about 300 yards west of the "House" vein, was explored, several small shafts sunk, and much of the vein above water level stoped out. A 4-foot Bryan mill was installed to pulverize the ore. As no records are now available it is impossible to give authentic information in regard to the production and average value of the ore mined. According to one report the average value of the ore obtained from the "House" vein was $\$ 5.27$ per ton, but another states that it averaged $\$ 10.00$ per ton. They all agree that the ore from the "Sulphur". vein was lower in value.

From 1885 to 1909 , when the present company bought the property, the mine passed through several hands, and while occasional attempts at development were made, very little ore was milled. It is reported that a cyanide plant was in operation in 1893 , but with what success is not known. ${ }^{a}$ The present company has reopened several of the old shafts and drives, sunk 2 shafts on the "Sulphur" vein to a depth of 84 and 100 feet, respectively and done considerable development work, chiefly on the "Sulphur" vein. After making trial runs with the old Bryan mill, a new building was erected in 1910 and a Lane mill installed, but only about 1,500 tons of ore have as yet been milled.

Present equipment.- The mine is equipped with 2 shaft houses, a mill, and several other buildings. A steam hoist is located at each of the shaft houses, and there is an air compressor to furnish compressed air for the drills. The mill contains a Blake crusher, feeder, slow-speed Lane mill, and 2 Traylor concentrating tables.

Underground development.-The "Sulphur" vein, having a strike of N. $30^{\circ} \mathrm{E}$., and an average dip of about $40^{\circ}$ toward the southeast; is developed by 2 hoisting shafts and several air shafts, with underground drives that connect them and extend for a distance of 500 feet or more along the vein. The "Sulphur" shaft, sunk on top of the hill, in the hanging wall at a distance of 60 feet from the outcrop, is vertical to a depth of 80 feet where it intersects the vein, and then follows the vein on

aNitze, H. B. C., and Wilkins, H. A. J., Gold Mining in North Carolina and Adjacent South Appalachian Regions, Bull, io, N. C. Geol. Survey, 1807, p. 38. 
an incline for about 42 feet, making the total depth below thic surface 100 feet. About 75 feet from the surface, drives extend in cither direction along the vein, connecting with the other shafts, and near the bottom of the incline 2 short drives run northeast and southwest. "The "H. V." shaft, near the branch, 340 feet northeast of the "Sulphur" shaft, is vertical and 83 feet deep, the first 30 feet being on the vein, which here is nenrly vertical for that distance. At a depth of 30 feet from the surface a drive along the vein connects with the "Sulphur" shaft, and 54 feet from the surface an 18-foot cross-cut running southeast intersects the vein, which at this point is further exposed by 2 short drives in either direction.

Practically all the stoping has been confined to the upper portion of the vein above the drive connecting the two hoisting shafts; and very little ore that would pay the cost of mining and milling remains in that part of
the mine.

'The "House" vein, outcropping about 250 yards enst of the "Sulphur" shaft, is not at present accessible, but the old stopes and surface cuts have a strike of $N$. $22^{\circ} \mathrm{E}$. A shaft, sunk about 350 yards southeast of the "Sulphur" shaft, did not strike the vein. Several adits have been driven under the hill near the north end of the old workings, and though they were not carried far enough to intersect the "House" vein, they expose a number of large lenses and stringers which approximately parallel that vein. 'The larger lenses encountered have been mined out above the water Ievel.

General description of the geology.-There are almost no surface outcrops in the vicinity of the Young American mine, but there are many exposures along Big Byrd Creek, which cuts directly across the strike of the rocks, 3 miles southwest of the property. On the east side of the creek, about half a mile sonth of Bowles' bridge, rocks outcrop which are apparently identical with the country rock exposed in the underground workings of the mine, and they are in the same line of strike. These rocks are intensely metamorphosed schists and gneisses, derived from bedded sedimentaries, which were probably arkosic sandstones and grits. About three-quarters of a mile southeast of the mine this series of altered sedimentary rocks passes into and is interbedded with quartzites, which are in places highly ferruginous, containing both specular hematite and magnetite. Crystals of magnetite, consisting of octahedrons $1 \mathrm{~cm}$. and less in diameter, which have weathered from the underlying rock, are found on the surface 300 yards northeast of the veins, and at several other localities on the property and in its immediate vicinity. The wall rock exposed in the mine usually contains much fine-grained magnetite. 
The hornblendic border facies of the main granite batholith is exposed about a mile southenst of the mine, and what is probably a tongue from the latter comes within three-quarters of a mile or less, outcrops of granite occurring along the branch that runs about that distance northenst of the mine.

Two varieties of gneiss are exposed in the underground workings: The dominant type is a dark greenish-gray, fine-grained rock, usually banded, and composed essentinlly of quartz, feldspar, hornblende, biotite, and chlorite, with smaller amounts of magnetite, calcite, and sericite; the other, which is similar except for the absence of most of the iron-bearing silicates, is a fine-grained, light gray rock, composed essentially of quartz, feldspar, sericite, and smaller amounts of chlorite and calcite. 'The chief mineral constituents in these rocks, while varying somewhat in their relative proportions, are always the same.

In the openings on the "Sulphur" vein, the light-colored gneiss occurs as a bed, varying from $11 / 2$ to 8 feet in thickness and lying between strata of the darker gneiss. It was also found on the dumps of some small pits and shafts near the line of strike of the "House" vein, about 200 yards south of the Dietz shaft, but in most openings on the property that are now accessible the dark hornblendic rock is the variety exposed.

There-are trio principal veins on the property that have been worked for gold; the "Sulphur" and the "House" veins. In the vicinity of the "House" vein there is a large number of small stringers and lenses which have been mined to a limited extent.

The "Sulphur" vein at the surface has an average strike of about N. $40^{\circ} \mathrm{E}$., which is approximately the same as that of the country rock, but locally there is considerable variation, and in the underground workings near the Chittenden air shaft there is a sharp change in strike from $\mathrm{N} .21^{\circ}$ to $53^{\circ} \mathrm{E}$. The dip is toward the southeast, changing from almost vertical in places near the surface to an angle of $30^{\circ}$ in some of the lower workings, the average for the first 150 feet from the outcrop being about $50^{\circ}$. The width varies from 6 feet down to a few inches, and the average is probably between 2 and 3 feet. Where the vein is several feet wide it consists of a single mass of quartz, but elsewhere it frequently breaks up into a number of approximately parallel stringers and lenses, forming a belt 6 or 7 feet wide in which the country rock between the veinlets may be more or less mineralized. (See figs. 6 and \%) In one instance noted, the veinlets instead of being parallel to the general inclination of the vein cut across it in such way as to suggest their formation in 
a zone of shear faulting (see fig. 9, p. 130). Where exposed in the underground workings, the "Sulphur" vein occurs in the light-colored gneiss and also in both the overlying and underlying, dark, hornblendic gneiss.

The "House" vein, 200 to 300 yards east of the "Sulphur" vein, has a strike of about $\mathrm{N}$. $22^{\circ} \mathrm{E}$., which would cause the two veins to intersect if they both maintain their courses toward the northeast. The "House" vein is said to have an average width of 5 or 6 feet, but as the old workings have caved and are not now accessible this statement could not be verified. The strike was determined by means of the old surface cuts and caved stopes along the outcrop. Near the southwestern end of the old workings the country rock seems to be chiefly the light-colored gneiss or schist, but where the adits have been driven under the hill near the northeastern extension of the vein, the country rock, wherever exposed, is a dark green hornblendic gneiss, similar to that found in the openings on the "Sulphur" vein.

The adits, above mentioned, were not carried far enough to strike the "House" vein, but they cut through a large number of lenticular veinlets that apparently parallel the main vein. These veinlets range from stringers a fraction of an inch in width up to lenses 2 feet thick and 25 feet or, more in length, and are pegmatitic in character, frequently carrying much -plagioclase feldspar-a mineral which is only occasionally present in the "Sulphur" vein. No openings have been made much below water level, but where the lenses have been mined their dip is practically vertical.

While the veins and country rock at the Young American mine are much broken by jointing, and there is in places a small amount of faulting along these joints, there is no evidence of important faulting since the formation of the veins. The irregularities in the strike and dip which were mentioned above are believed to be due to faulting and fracturing prior to the formation of the veins, which left openings or lines of weakness along which the solutions that deposited the ores were able to penetrate.

In addition to the veins described above, several quartz veins carrying considerable tourmaline outcrop in the vicinity of the mine, but at the surface they contain only traces of gold and therefore practically no development work has been done on them.

Detailed descriptions of the veins and wall rock.-At the bottom of the incline from the "Sulphur" shaft, about 100 feet from the surface and 65 to 75 feet below the natural water level, the vein consists of lenses and irregular masses of quartz distributed over a belt 5 to 6 feet in width, which is here confined to the bed of light-colored gneiss. A sketch, drawn to scale, 
showing the distribution of vein quartz and the structural relations of the wall rock, is given in fig. 6. Only a short distance above this point the quartz begins to collect together so as to form a single well-defined and continuous vein.

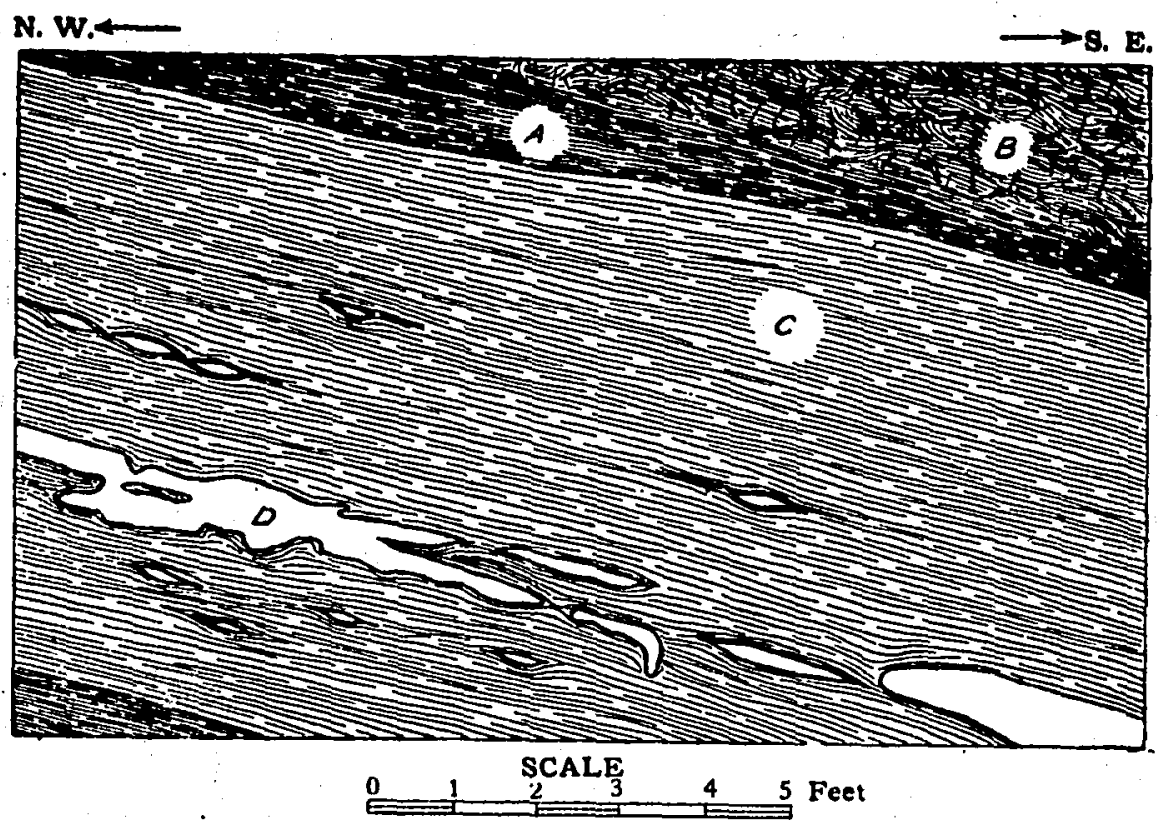

Fig. 6.-Vertical section showing vein at bottom of "Sulphur" incline, Young American Mine. $A$, dark-colored gneiss; $B$, partly decomposed gneiss; $C$, light-colored gneiss; $D$, vein quartz.

The vein quartz is white, translucent and coarsely crystalline. It contains a little over 1 per cent. of pyrite, slightly cupriferous and sometimes associated with fine-grained magnetite, and, rarely, crystals of white feldspar difficult to distinguish from quartz are present. . In places there are small masses of chlorite and flakes of biotite which probably represent altered inclusions of country rock. A carefully collected, average sample assayed $\$ 1.34$ in gold with no silver. In the vicinity of the quartz masses, the gneiss is also mineralized to a considerable degree, containing disseminated grains of pyrite and many small veinlets of quartz which decrease in number and size on passing away from the vein stringers, so that they are not noticeable at $a$ distance of 4 or 5 feet. These veinlets range from half an inch down to those that are microscopic in size and usually 
parallel the schistosity; the pyrite occurs in small grains and elongated masses less than $1 \mathrm{~cm}$. in diameter and is frequently more plentiful along the quartz veinlets.

The dark-colored gneiss overlying the bed of lighter color, while apparently fresh near the contact, passes gradually into partially decomposed rock a short distance above (see fig. 6), and this illustrates the great depth to which weathering has reached in this area. As this was the deepest opening accessible in the area when the region was studied by the writer, average samples of the different rocks exposed at this point were carefully taken. A partial analysis of the vein quartz was made, and complete analyses of the two varieties of gneiss and also of the partly decomposed gneiss. For convenience in comparison these analyses are assembled in the table given below, which is followed by a detailed petrographic description of the rocks. The analyses are arranged in the order of their relative distance from the vein quartz, which is also the order of decreasing mincralization as is indicated by the decreasing percentages of $\mathrm{SiO}_{2}$ and $\mathrm{FeS}_{2}$.

Analyses of vein and wall rock from the Young American Gold Mine.

\begin{tabular}{|c|c|c|c|c|}
\hline$\because$ & [ & II & III . & IV \\
\hline 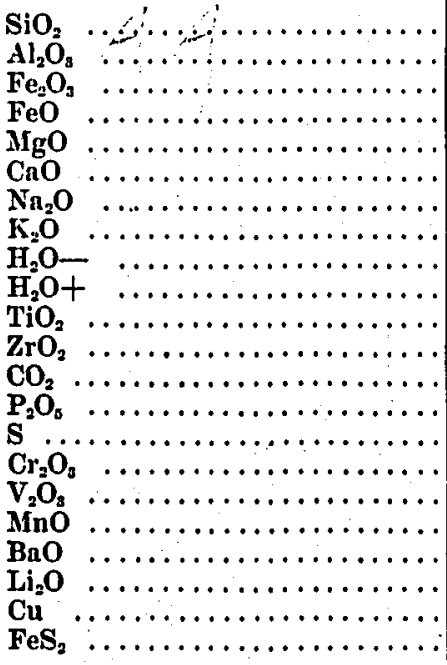 & 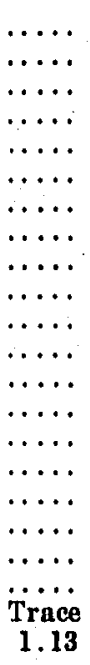 & $\begin{array}{r}75.72 \\
13.14 \\
0.33 \\
1.44 \\
0.31 \\
1.07 \\
3.77 \\
1.75 \\
0.12 \\
1.00 \\
0.10 \\
0.01 \\
0.63 \\
0.04 \\
\cdots \cdots \\
\because \cdots \\
\because \ldots .02 \\
0.02 \\
\text { Trace } \\
\text { Trace } \\
0.62\end{array}$ & \begin{tabular}{r}
66.68 \\
15.25 \\
1.46 \\
3.78 \\
2.80 \\
2.33 \\
3.56 \\
1.65 \\
0.33 \\
1.26 \\
0.41 \\
\hdashline 0.36 \\
0.06 \\
$\cdots \cdots$ \\
$\cdots \cdots$ \\
\hdashline 0.09 \\
Trace \\
Trace \\
0.00
\end{tabular} & $\begin{array}{r}63.68 \\
16.11 \\
4.05 \\
2.67 \\
3.55 \\
2.18 \\
3.75 \\
1.43 \\
1.07 \\
0.96 \\
0.46 \\
\ldots \ldots \\
\dddot{0.06} \\
. \text { Trace } \\
0.01 \\
0.01 \\
0.08 \\
\ldots \ldots . \\
\text { Trace } \\
\text { Trace } \\
\text { Trace }\end{array}$ \\
\hline \multirow[t]{2}{*}{$\begin{array}{l}\text { Gold (ounces) } \\
\text { Silver (ounces) } \\
\text { Siln } \ldots \ldots \ldots \ldots \ldots\end{array}$} & $\begin{array}{l}0.065 \\
\cdots \cdots\end{array}$ & $\begin{array}{l}\text { Trace } \\
\text { Trace }\end{array}$ & $\begin{array}{l}\text { Trace } \\
\cdots \cdots\end{array}$ & $\begin{array}{l}\text { Trace } \\
\cdots \ldots\end{array}$ \\
\hline & & 89.90 & 100.21 & 100.07 . \\
\hline
\end{tabular}


I. Vein quartz ( $D$ in fig. 0 ). This sample contained 0.87 per cent. iron in excess of the amount necessnry to form pyrite, the excess being present ns a constituent of magnetite and chlorite. Determinntions made by E. E. Burlingane and $\mathrm{Co}$.

II. Light-colored gneiss ( $C$ in fig. 0 ). Annlysis made by Roger C. Wells; gold and silver determined by $\mathrm{E}$. E. Burlingame and $\mathrm{Co}$. Another sample of this rock nssnyed by the writer gnve $0.050 \%$ of gold per ton.

III. Dark-colored gneiss ( $A$ in fig. 0 ). Annlysis made by Roger C. Wells; gold and silver determined by the writer.

IV. Decomposed dark-colored gneiss ( $B$ in fig. 6 ). Analysis mude by Foger $C$. Wells; gold and silver determined by the writer.

'The dark-colored gneiss is gray, and in places has a slightly greenish tinge. It is fine-grained, even-granular, and the minerals are imperfectly segregated into parallel bands $1 \mathrm{~mm}$. or less in width, which are frequently folded or contorted to a small extent. The dark bands are due to the presence of biotite, chlorite, hornblende, and magnetite; the light bands are composed chiefly of quartz with a little sericite. Pink garnets, about $2 \mathrm{~mm}$. in diameter, more or less crushed and elongated parallel to the schistosity, occur scattered through the rock, and a little pyrite may also be distinguished.

Examined microscopically, the rock (Spec. 112-A) has a well-defined schistose structure, the different minerals being oriented parallel to their greatest élongation, and largely segregated into bands which differ from one another in size of grain ns well as in mineral composition. In the order of relative abundance the minerals present in the slide are quartz, feldspar, biotite, chlorite, hornblende, magnetite, carbonate (calcite ?), pyrite, and sericite. The quartz grains are usually clear, show no optical distortion, and contain occasional rutile needles, and other minute inclusions. Some of the larger bands consist almost exclusively of quartz, the individual grains of which they are composed being slightly larger than those in the rest of the rock. These bands are probably chiefly due to the recrystallization of silica originally present in the rock, but may be formed in part from quartz brought in by the rein-forming solutions. Much feldspar (probably oligoclase) is present in the slide. It is partly kaolinized, seldom shows twinning, and, as the index of refraction is practically the same as quartz, is hard to distinguish from the latter. The biotite is light brown to greenish-brown in color, strongly pleochroic, and frequently shows partial alteration to chlorite. There is much chlorite present, occasionally showing multiple twinning, and it appears to have been derived chiefly from the hornblende. Hornblende occurs in two varieties; one light green in color, the other light brown to nearly colorless. It is extensively altered with the formation of carbonate (calcite ?) and chlorite. In places numerous fragments of hornblende occur, 
separated and completely surrounded by calcite, which extinguish simultaneously under crossed nicols, showing that all of the fragments belong to a single crystal which has undergone partial alteration. Much finegrained magnetite is present and occasionally a little pyrite.

In the chemical analysis, the excess of magnesium over calcium indicates that the rock is sedimentary in origin, and this is confirmed by the structural relations. Chemical analysis as well as microscopic examination shows that weathering has begun to affect the rock even where freshest. In comparing the analysis of the freshest material with that of the partly decomposed rock, it is seen that the chief changes, aside from kaolinization of the feldspars, have been the removal of carbonate and the oxidation of much of the ferrous iron to the ferric condition.

As the light-colored gneiss at this point is nearer to the quartz stringers than the darker gneiss, it contains more quartz veinlets and a larger amount of pyrite. The rock (Spec. 112-C) is white to light gray in color, and distinctly banded, though this feature is not as noticeable as in the darker gneiss, because of the lack of contrast in the colors of the principal constituents-quartz, sericite, and feldspar. The bands are frequently contorted, especially in the vicinity of the quartz stringers and lenses. The small veinlets of quartz, ranging up to about $1 \mathrm{~cm}$. in diameter, are usually parallel to the banding, but in places cut directly across. Pyrite occurs in grains and small lenticular masses elongated "parallel to the schistosity, is sometimes associated with magnetite, and is more plentiful in the vicinity of the quartz veinlets. A little chlorite, occasional pink garnets, crushed and elongated.parallel to the schistosity, and very rarely needles of black hornblende, make up the minor constituents which are recognizable in the hand specimen.

Microscopic study shows that the principal mineral constituents in the order of their relative abundance are quartz, sericite, feldspar, chlorite, and carbonate (calcite ?). The textural characteristics and mineral composition of the rock are similar to the darker gneiss (112-A) excepting that quartz and sericite are more abundant, while biotite and hornblende are essentially absent. The minerals, particularly sericite, are largely segregated into parallel bands. The feldspars are not so extensively kaolinized as in the overlying rock, but appear to be similar in composition. .They are seldom striated and have an index of refraction only a little below quartz, indicating that they are probably near albite-oligoclase in composition. Orthoclase is rare if present, and probably most if not all of the potash content is in the form of sericite. An analysis of this rock is given in column II of the table on page 124. 


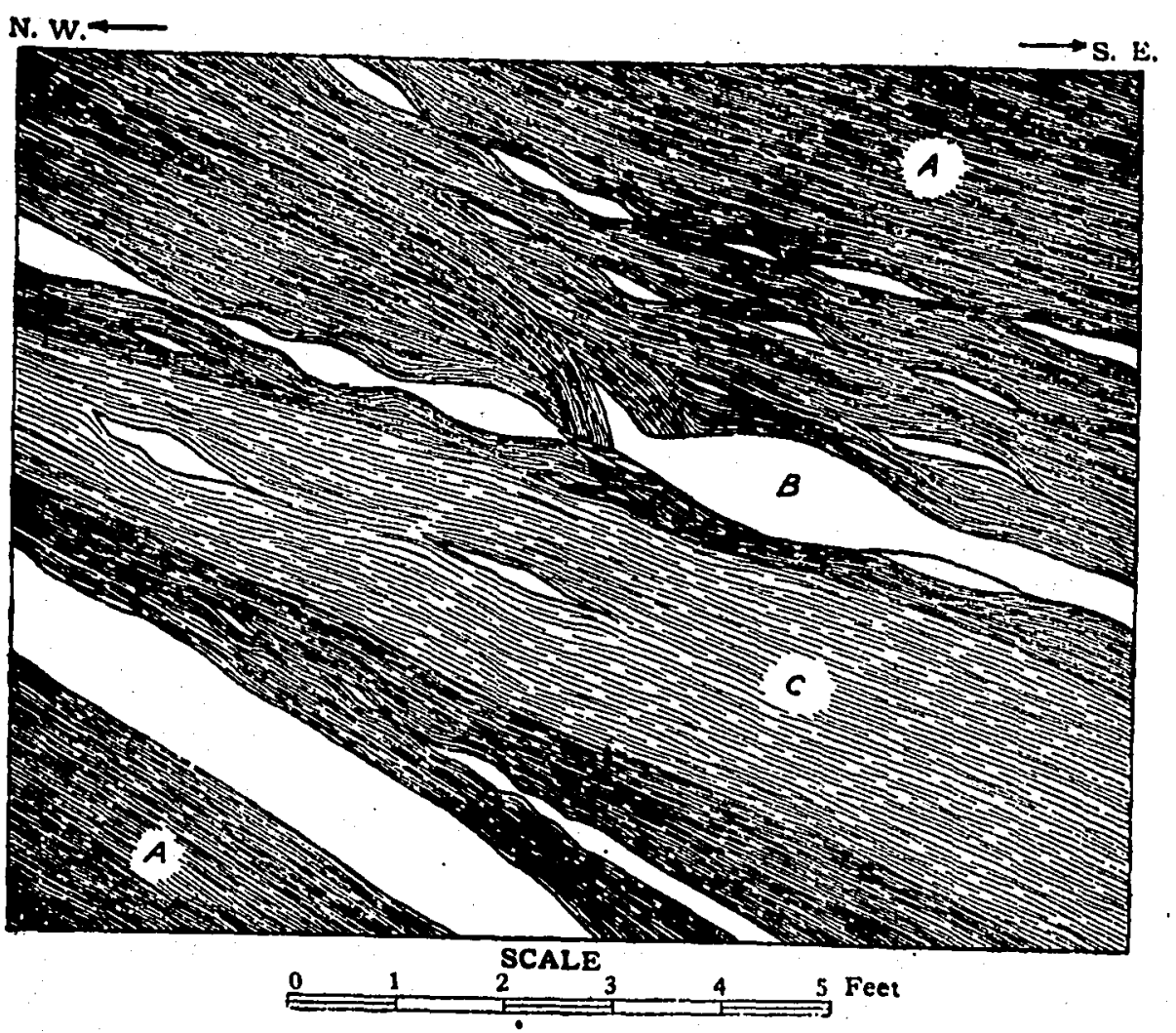

Fig. 7.-Sketch showing distribution of voin quartz in light- and dark-colored gneisses at the Young American Mine. $A$, dark-colored gneiss; $B$, vein quartz;

The sketch shown in fig. 7 indicates the appearnance of the face in the drive running southeast near the bottom of the "Sulphur" incline. 'The location is about 10 feet above the sketch shown in fig. 6, and 18 feet southeast. Here the bed of light-colored gneiss is thinner, and the vein quartz chiefly distributed in the overlying and underlying gneiss. The quartz vein, about a foot wide, shown in the lower left hand corner of the sketch, contains chalcopyrite as well as pyrite. Mr. Knutzen, Superintendent of the Young American mine, states that samples from this 1-foot vein yielded from $\$ 11.20$ to $\$ 24.00$ gold per ton, and that a picked specimen showing chalcopyrite carried $\$ 50.00$ per ton. The value of the ore in this drive seems to vary greatly within short distances; an average sample, obtained from 6 buckets (about 11/2 tons) after passing through the crusher, assayed $\$ 8.00$, while a similar sample from 4 buckets of ore 
that were obtained as a result of the next round of blasting gave only $\$ 1.00$ per ton. According to Mr. "Knutzen the gold content is highest where chalcopyrite is found.

A hand specimen (116) was obtnined from this drive showing the two varieties of gneiss in contact. The line of contact is quite sharp and is parallel to the banding which is slightly contorted. The rock is cut by narrow veinlets of quartz commonly parallel to the banding and in places showing a tendency to follow the contact between the light and dark gneiss, but which frequently cut directly across the schistosity. A thin section was made to show one of these veinlets about $0.5 \mathrm{~cm}$. in width. Under the microscope, numerons liquid- and gas-filled cavities can be seen in the quartz, usually arranged in rows or planes that occasionally pass without interruption from one crystal individual to another. Some of the cavities contain bubbles in constant and rapid vibration. The dark variety of gneiss, which in the slide forms the walls of the veinlet, is similar to that described above. The constituent minerals are quartz, feldspar, biotite, hornblende, chlorite, sericite, and calcite, and a little pyrite, magnetite, and ilmenite partly altered to leucoxene. A small colorless garnet, showing slight anomalous biaxial character, is also present in the slide. In several places pyrite occurs, bordered by a narrow rim of magnetite, which was probably produced under conditions of partial oxidation.

The smaller veinlets, especially in the light-colored gneiss, show a strong tendency to form lenses, but they are not as perfectly developed as those in the "Middle" vein at the Tellurium mine. A photograph of some small lenses in light-colored gneiss from the "Sulphur" shaft is shown in Pl. X, fig. 2.

Pyrite is more plentiful in the light-colored gneiss than in the clark variety, and occurs in elongated grains or broken lines parallel to the banding. Some secondary pyrite was noted along joint planes in both the vein quartz and the country rock.

Near the bottom of the "Sulphur" shaft, about 80 feet from the surface and just above the incline, the quartz vein is 2 feet wide, and the dark gray, biotite-sericite gneiss, which forms the foot wall, is heavily impregnated with pyrite and contains occasional lenses and veinlets of quartz. Mr. Knutzen obtained assays of $\$ 3.60$ gold per ton from this mineralized wall rock, which extends several feet from the vein.

In $\mathrm{Pl}$. X, fig. 1, is shown a photograph of one of the quartz veinlets in contact with the heavily mineralized gneiss. A crystal of light bluc cyanite $6 \mathrm{~mm}$. wide and $3 \mathrm{~cm}$. long extends from the wall rock out into 


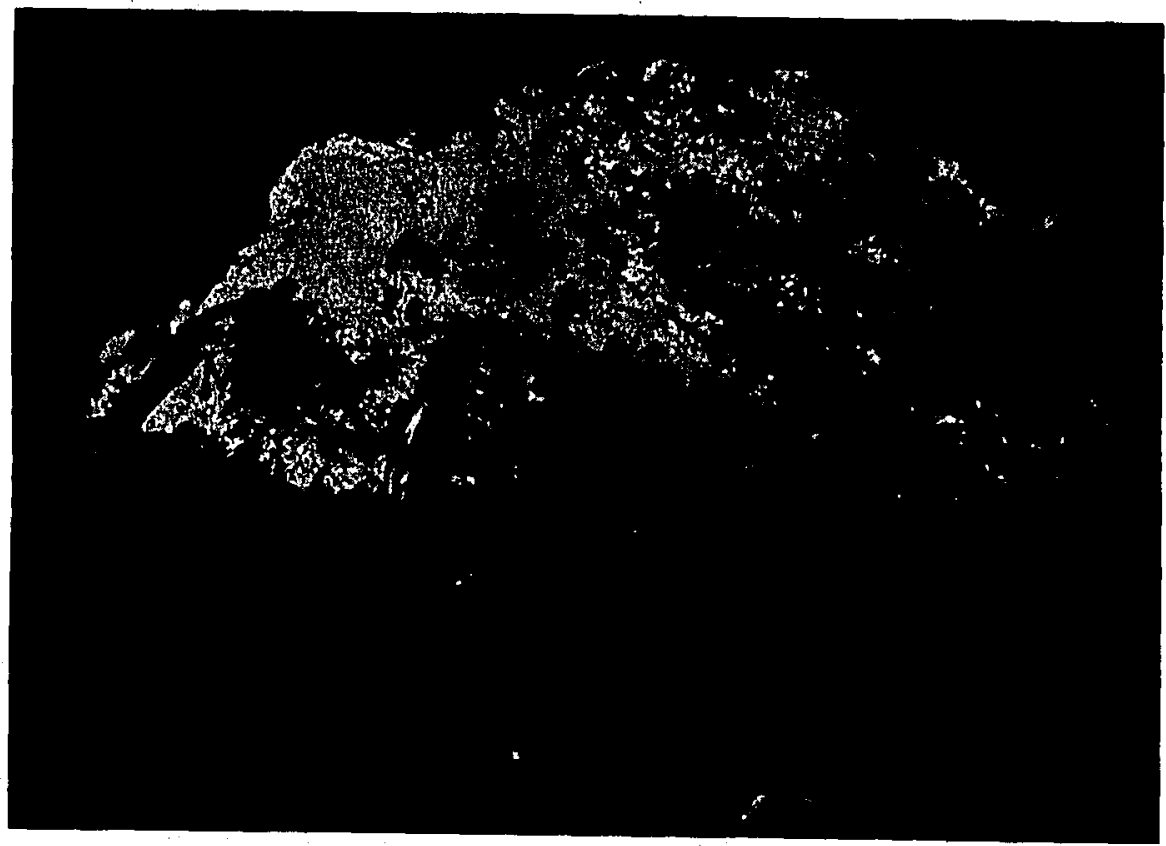

lig. 1.-Photograph slowing cyunite and muscovite in vein quartz from the Young American mine. $C$, cyanite; $M$, muscovite; $Q$, vein quartz; $P$, pyrite; $G$, gneiss.

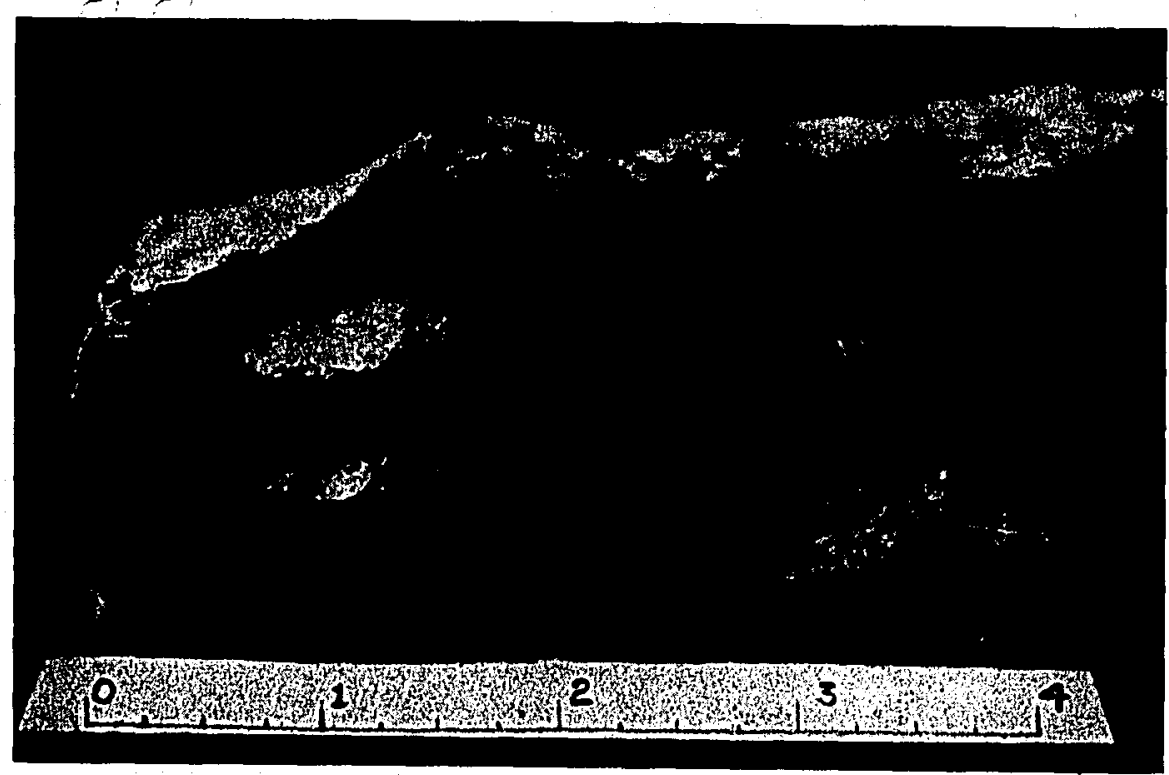

Fig. 2.-Lenses of vein quarty in gueiss from Young Amerienn mine. CYANITE AND MUSCOVIIE IN QUARTY, AND QUARTZ LTNSES IN GNEISS. 
the quartz. 'The vein quartz also contains a little white feldspar, flakes of muscovite, and a few specks of chlorite. Calcite occurs in the gneiss and is partly concentrated along the contact with the veinlet. Very little pyrite is present in the quartz, but it is abundant in the gneiss, where it occurs in bands and broken lines parallel to the schistosity, which is much folded in the vicinity of the veinlet. Pieces of vein quartz, similar to that just described, but containing both cyanite and tourmaline, wore found on the surface. The cyanite is sparingly distributed through the quartz in light blue prismatic crystals 3 to $4 \mathrm{~mm}$. wide and $1.5 \mathrm{~cm}$. long; and the tourmaline occur's in black prisms 2 to $3 \mathrm{~mm}$. in diameter, which usually radiate in all directions from a common center. Elsewhere cyanite was noted in the metamorphosed wall rock near the veins, but in the specimens described above it occurs in detached prisms within the vein quartz itself.

In the foot-wall, 5 or 6 feet from the vein at the bottom of the "Sulphur" s]aft, the rock is a dark gray, fine-grained, even-granular gneiss, with well-marked banding. It shows no evidence of mineralization, pyrite as well as the quartz veinlets being absent. The light-colored hands in the rock range up to $2 \mathrm{~mm}$. in width and are composed chiefly of feldspar and quartz, though they are not as a rule distinguishable from. each other in the hand specimen. The dark bands are narrower and consist essentially of biotite, hornblende, and chlorite. Much magnetite is present in small grains, but no garnets were noted. Under the microscope the rock is similar to the dark variety of gneiss described on pages 125-126, except that feldspar seems to be dominant over quartz, possibly because of the absence of silicification by vein-forming solutions. In the order of their relative abundance the minerals present are feldspar (probably. andesine or: oligoclase-andesine), quartz, hornblende, biotite, chlorite, calcite, and magnetite, with a few scattered grains of zircon and titanite. 'The hornblende occurs in two varieties, one green in color, and the other yellowish-brown. The latter, which is subordinate in amount, has parallel extinction and is present in long ragged prisms. It is one of the orthorhombic ampliboles. The other minerals present no unusual characteristics.

The drive connecting the "Sulphur" and "H. V." shafts exposes an offset of 10 to 15 feet in the course of the vein just north" of the "Sulphur" shaft, the space between being occupied by a zone containing numerous lenses and irregular masses of quartz. At the shaft the vein is standing nearly vertical. 'The sketch given in fig. 8 shows the distribution and shape of the quartz masses exposed on the enst side of the drive about $1 \dot{5}$ feet north of the shaft. The country rock here is the dark variety of gneiss, and is much folded and contorted. 


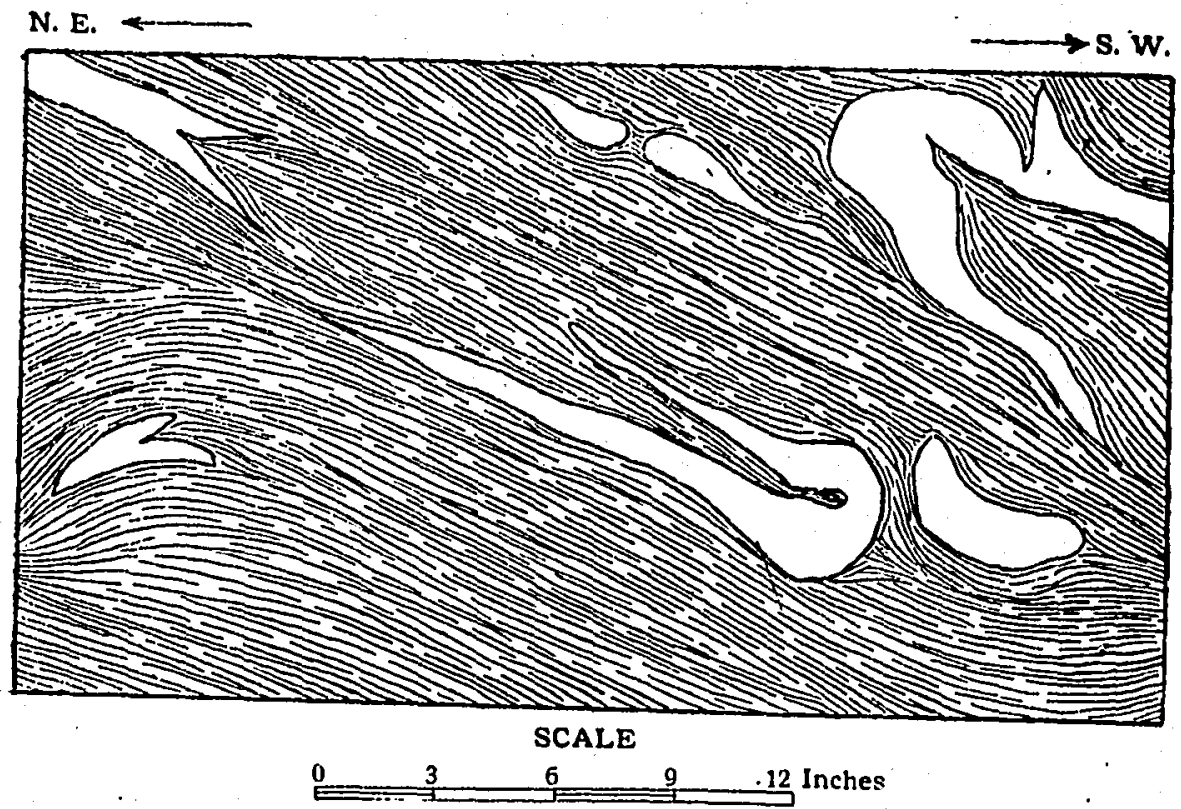

Fig. 8.-Vertical section showing distribution of vein quartz in a sheared zone at
the' Young American Mine. S. E. $\div$

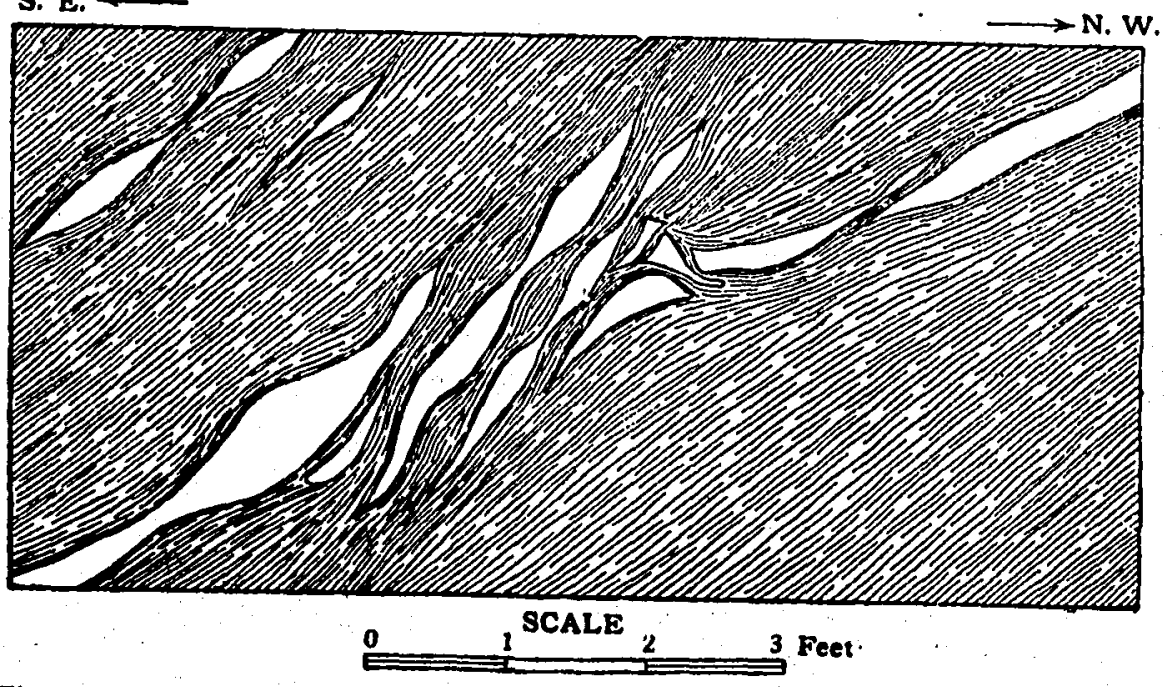
Fig. 0.-Sketch showing distribution of quartz lenses in a zone of slenr faulting,
Young American Mine. 
There is another sharp break in the course of the vein near the Chittenden shaft where the strike suddenly changes from $N$. $21^{\circ}$ to $53^{\circ} \mathrm{E}$., and at this point there is a similar breaking up of the vein into separate lenses and irregular masses. A sketch of the vein, exposed in a small opening opposite the Chittenden shaft, is given in fig. 9. The distribution of the quartz lenses relative to the average strike and dip of the vein suggests that they were formed in a zone of shear faulting. The country rock is the dark variety of gneiss which is slightly mineralized in the immediate vicinity of the vein. A sample from the hanging wall, assayed by the writer, gave 0.03 ounces gold per ton. A 12-ton mill run of mineralized gneiss from the foot-wall of the vein, in the main drive about 40 feet northeast of this place, is said to have averaged $\$ 3.60$ gold per ton.

In the "H. V." shaft, the vein is nearly vertical to a depth of 30 feet, at which point it begins to dip toward the southeast and leaves the shaft. (See fig. 10.) Where the vein is exposed by the cross-cut from the shaft, 54 feet below the surface, it is 3 to 6 feet in width, dips at an angle of $40^{\circ}$ toward the southeast and has a strike of about N. $30^{\circ} \mathrm{E}$. The wall rock on both sides of the vein is the dark variety of gneiss, much decomposed, and showing no evidence of mineralization, but Mr. Knutzen states that a sample from the hanging wall assayed $\$ 0.50$ per ton. The vein quarti is irregularly - mineralized, containing pyrite, chalcopyrite, and occasionally a very little sphalerite.

The sulphides are strung out in narrow lines or small lenticular masses approximately parallel to the walls, and the sphalerite usually occurs separate from the other ore minerals instead of being intermixed with them. A little white feldspar occurs in some of the quartz, but appears to be chiefly confined to the border portions of the vein. Very rarely, black tourmaline is present in small radiating prisms, and one specimen was found with a speck of free gold about $0.4 \mathrm{~mm}$. in diameter, resting on the tourmaline, which is imbedded in quartz and surrounded by a small: amount of limonite derived from pyrite. Pieces of the vein frequently show imperfect crystals of quartz lining joint planes, and several small vug-like openings were seen in which the walls were lined in a similar manner. It is probable, however, that these openings are due to the oxidation and removal of pyrite rather than to spaces that were left unfilled when the vein was originally formed. Some of these vug-like spaces contain a little pyrite, more or less oxidized, and in places the sulphide has a crystal form closely resembling marcasite. Small flakes of chlorite and muscovite occur in parts of the vein. 
The gold is not evenly distributed throughout the vein, much of it being apparently concentrated in the sulphides. Mr. Knutzen obtained an assay of 5.8 ounces of gold per ton from a piece of the chalcopyrite. A mill run made on 8 tons of ore from the vein at this point averaged $\$ 3.20$ per ton.

"The "H. V." shaft passes through the bed of light-colored gneiss about 15 feet below the cross-cut to the vein. At this point it is 3 to 4 feet thick

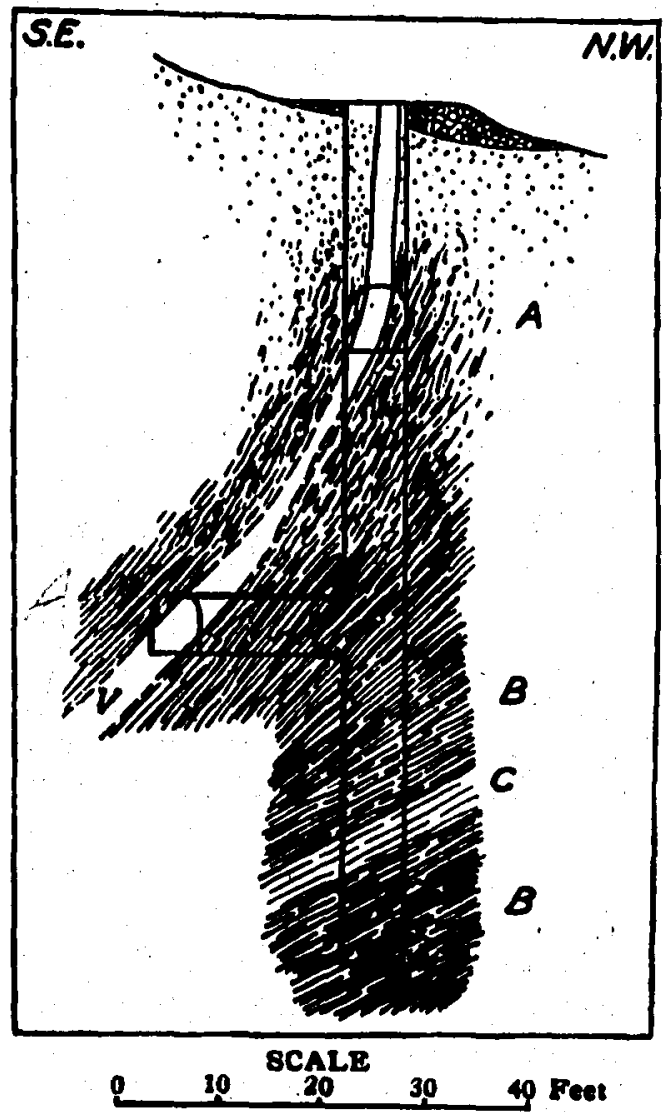

Fig. 10.--Vertical section through " $H$. V." shaft, Young American Mine. $V$, vein; $d$, decomposed gneiss; $B$, dark-colored gneiss; $C$, light-colored gneiss.

and dips towards the southeast at an angle of about $25^{\circ}$ (see fig. 10). The rock is white and highly lustrous on fracture surfaces parallel to the cleavage. In addition to the quartz and sericite, a little finegrained pyrite and rarely small needle-]ike prisms of hornblende are sparingly scattered through the rock. In thin section (Spec. 506) under the microscope, the rock shows distinct banding due to the partinl localization of sericite in narrow parallel bands. Quartz, the dominant mineral, occurs in small rounded grains associated with feldspar (albite ?), which is usually clear and unstriated, though mutiple twinning may be seen in places. Small cubes of pyrite and a very.little chlorite make up the accessory mincrals.

The rock exposed in the bottom of the shaft is a dark greenish-gray gneiss in which the banding is only imperfectly developed. In thin section (Spec. 503), the minerals identified in order of their abundance were hornblende, feldspár, quartz, biotite, chlorite, magnetite, and a little carbonate. The hornblende is light green in color 
and has rather low interference colors. The cleavage is good but the crystals are irregular in outline and contain occasional inclusions of the other minerals. Alteration to cllorite is frequently shown. Part of the feldspar is twinned after the albite law, but much of it is unstriated and difficult to distinguish from quartz, which it closely resembles in refraction and birefringence. The biotite is light brown in color and strongly pleochroic. Angular grains of magnetite are scattered through the slide and a little carbonate is present.

The small amount of carbonate contained in the gneiss just described, and its absence in the light-colored variety from the "H. V." shaft, is in marked contrast to its abuindance in specimens from other parts of the mine. The relative scarcity of carbonate in these rocks may be due to greater depth below water level-75 or 80 feet-or possibly it is to be explained by distance from the vein-about 25 or 30 feet.

In the sonthwest end of the mine near the "12th of May" shaft the vein is 2 inches to 3 feet wide and averages about 14 inches. For some distance it splits up into two separate stringers which in places are slightly contorted. Slickensides were noted in a number of localities, but the vein is little nflected by faulting. Radiating prisms of black tourmaline are of rare occurrence, being found occusionally in quartz from near the shaft. Most of thic wall rock in this portion of the mine shows much decomposition, but in the floor of the drive 125 feet southwest of the "Sulphur" shaft there is a little fresh gneiss exposed on the foot-wall side of the vein. 'The rock (Spec. 118) is white to light greenish-gray in color where fresh, but along joint planes it is stained brown from the alteration of iron minerals, and in places the stain extends several inches from the fracture surfnce. Quartz and feldspar are the chief minerals with chlorite, hornblende, calcite, biotite, cyanite, and sericite present in smaller quantity. Cubes and irregular grains of pyrite are sparingly disseminated through the rock, and upon assnying an average sample it yielded 0.01 ounce of gold per ton.

Examination under the microscope shows that part of the quartz is present in small veinlets, probably as a result of mineralization by the vein-forming solutions. Part of the feldspar shows albite twinning, and is unquestionably acid plagioclase, but in most cases the twinning is absent and identification could not be made with certainty. There probably is some orthoclase present, but most of the unstriated feldspar is plagioclase. There are large areas in the thin section consisting of intercrystallized calcite and chlorite, possibly derived from hornblende, but some of the chlorite 
was clearly formed from biotite. Areas of fine scaly sericite are present, some of which contain nuclei of unaltered mineral-probably cyanite.

The ore seems to occur in shoots that dip steeply toward the left as they descend along the vein, but this can not be verified until more development work has been done. One such ore shoot was found near the "Sulphur" shaft, and another between the "H. V." and the Chittenden shafts.

In the adits that were driven under the hill toward the "House" vein most of the country rock is soft and decomposed, but at several places where the floor of an adit approaches water level, fresh rock is encountered. Both the fresh exposures and the residual decay indicate that the rock is normally a hornblendic gneiss or schist, essentially the same as the dark variety of gneiss found in the underground workings on the "Sulphur" vein. In the immediate vicinity of the numerous veinlets and lenses which are exposed in the adits and have been worked to a limited extent for gold, the country rock exhibits certain important variations from the normal, which later will be described in detail.

The country rock, exposed near the portal of a prospecting tunnel that was started on the northwest side of the hill, is almost massive in the hand specimen (502), but shows a distinctly schistose structure under the microscope. Megascopically it is a dark greenish-gray, fine-grained rock, containing numerous idiomorphic garnets 1 to $2 \mathrm{~mm}$. in diameter, and occasional rare grains of pyrite. The constituent minerals are amphibole, quartz, soda-lime feldspar, chlorite, magnetite; carbonate, a very little greenish-brown biotite, and quartz. In thin section most of the amphibole is green to bluish-green in color, and probably corresponds to common hornblende, but there are two other varieties present in small amounts. One is pleochroic in shades of light pink and dark greenish-gray, the interference colors being blies and greens of the second order, and is monoclinic in crystallization; the other is light yellowish-brown in color and orthorhombic in its crystallization. The latter mineral is present in much of the gneiss in this vicinity, but always in very small quantity. Hornblende is dominant over the other minerals and usually shows parallel orientation. Some of the feldspar (andesine) shows albite twinning, but much of it is unstriated and difficult to distinguish from quartz, which it resembles in refraction and birefringence. Much of the chlorite shows multiple twinning.

The veinlets and lenses vary from a fraction of an inch in thickness up to masses 2 feet wide and 25 feet or more in length. The shape of some 
of the old openings suggests that even larger lenses may have been removed by previous mining operations. The veinlets are exposed in the adits on both sides of the hill, but are more plentiful in those that were driven from the west side. The larger lenses consist essentially of quartz, with pyrite and a little feldspar, the latter being chiefly concentrated near the walls though also occurring throughout the mass. In some of the smaller veinlets feldspar in places is dominant over quartz. Along fractures in the quartz-feldspar rock, much white mica is found in flakes 6 or $7 \mathrm{~mm}$. in diameter with no regular orientation. While these crystals are quite large - and may be primary muscovite, their localization along fractures indicates that they are probably secondary, derived from feldspar. Pyrite is very unequally distributed, occurring locally in masses several inches across, while elsewhere it is present in small quantity only. The larger masses seen were extensively altered to limonite.

Gold occurs in the native state both in the quartz and in pyrite, and there may also be a little telluride of gold present since tellurium has been detected in the ore. Mr. Knutzen states that the ore seems to be richest in gold near the walls of the lenses. The average value of $763 / 4$ tons of ore obtained from these lenses and veinlets was $\$ 4.10$. Small grains of visible gold ranging up to $1 \mathrm{~mm}$. and over in diameter are occasionally seen.

A piece of quiartz, obtained from one of the lenses, contains embedded in it a grain of gold, averaging about $0.75 \mathrm{~mm}$. in diameter, which is in contact with a minute speck of some soft cleavable mineral with metallic luster-probably tetradymite or sylvanite. Only $3 \mathrm{~mm}$. distant from the gold, there is a cavity in the quartz, roughly cubical in shape, and about $1.5 \mathrm{~mm}$. in diameter, which was filled with tetradymite, and in the latter a small crystal of pyrite was embedded. Part of the tetradymite was removed and tested for identification. It is tin-white in color, has a high metallic luster, perfect basal cleavage with flexible laminæ, and is quite soft, readily marking paper. Heated before the blowpipe it fuses easily and gives an orange-yellow sublimate. Upon gently heating with sulphuric acid in a test tube the acid assumes the beautiful reddish-violet color distinctive of tellurium. The same specimen of quartz contains a little kaolinized feldspar and some dark brown limonite derived from pyrite.

A thin section (Spec. 498) from one of the quartz-feldspar veinlets was examined under the microscope. The quartz individuals range up to 3 $\mathrm{mm}$. in diameter, contain numerous irregular gas- and fluid-filled cavities, usually arranged in long rows, and show slight wavy extinction, but no granulation or other evidence of crushing. The feldspars range up to. 
$1 \mathrm{~cm}$. or more in diameter, and are ensily distinguished from quartz because of a slight cloudiness due to partinl alteration. Multiple twinning after the albite law is sometimes though not always present. The average index of refraction is a little less than that of quartz, and this together with the extinction angle indicates a composition of approximately $\mathrm{Ab}_{2} \mathrm{An}_{1}$ (oligoclase-andesine).$^{a} \mathrm{~A}$ little sericite occurs in places, usually in clusters of curved and radiating scales. The only other minerals noted in the slide were a few grains of ilmenite and its alteration product leucosene.

The larger lenses appear to be parallel to the strike and dip of the country rock, but many of the veinlets cut directly across. In places, as shown in fig. 11, small jrregular veinlets and lenses r'un in every conceivable direction. Where stringers of quartz and feldspar cul across the cleavage of the gneiss, smaller veinlets branch off at short intervals and run parallel to the schistosity, giving rise to a banded rock which is very striking in appearance.

Specimens of this rock consist of alternating bands of light and dark minerals, ranging up to $1.5 \mathrm{~cm}$. in width, which widen here and narrow there, and frequently pinch out entirely. Some of the light-colored bands are composed essentially of quartz and feldspar, while other's consist largely of sericite; and the dark-colored bands are composed chiefly of dark green hornblende, with sulphides of iron and magnetite abundant in places. The quartz-feldspar bands resemble veinlets, and when the rock is fresh it is difficult to distinguish between the two component minerals, as they are both white. The rock breaks most readily along the sericite bänds and there presents a light gray surface on which long, narrow, glistening streaks of sericite are plentifully sprinkled. These streaks of sericite average about $2 \mathrm{~mm}$. in width and range up to 2 or $3 \mathrm{~cm}$. in length. On some of the specimens a little light blue cyanite can be distinguished, and the sericite streaks are probably due to the alteration of that mineral. The dark-colored bands. when narrow consist of dark green hornblende with a sprinkling of magnetite, but some of the wider bands have a narrow border of coarsely crystalline hornblende 2 to $3 \mathrm{~mm}$. wide along their contacts with the quartz-feldspar veinlets, while their central portions are filled with a fine-grained mixture of carbonate, hornblende, pyrrhotite, pyrite, and magnetite.

\footnotetext{
a A specimen of this feldspar was submitted to Dr. E. S. Larsen, Jr., for accurnte determination of the maximum and minimum indices of refraction by the immersion method. His report is as follows: "Oligoclase to andesine. Dominantly andesine or oligoclase-andesine.

$$
\alpha=1.539 \pm 0.003 \text { to } 1.544 \pm 0.003
$$

Extinction on the rhombic section $1212^{\circ}$ andesine."
} 
S. $\mathbf{E}, \leftarrow$
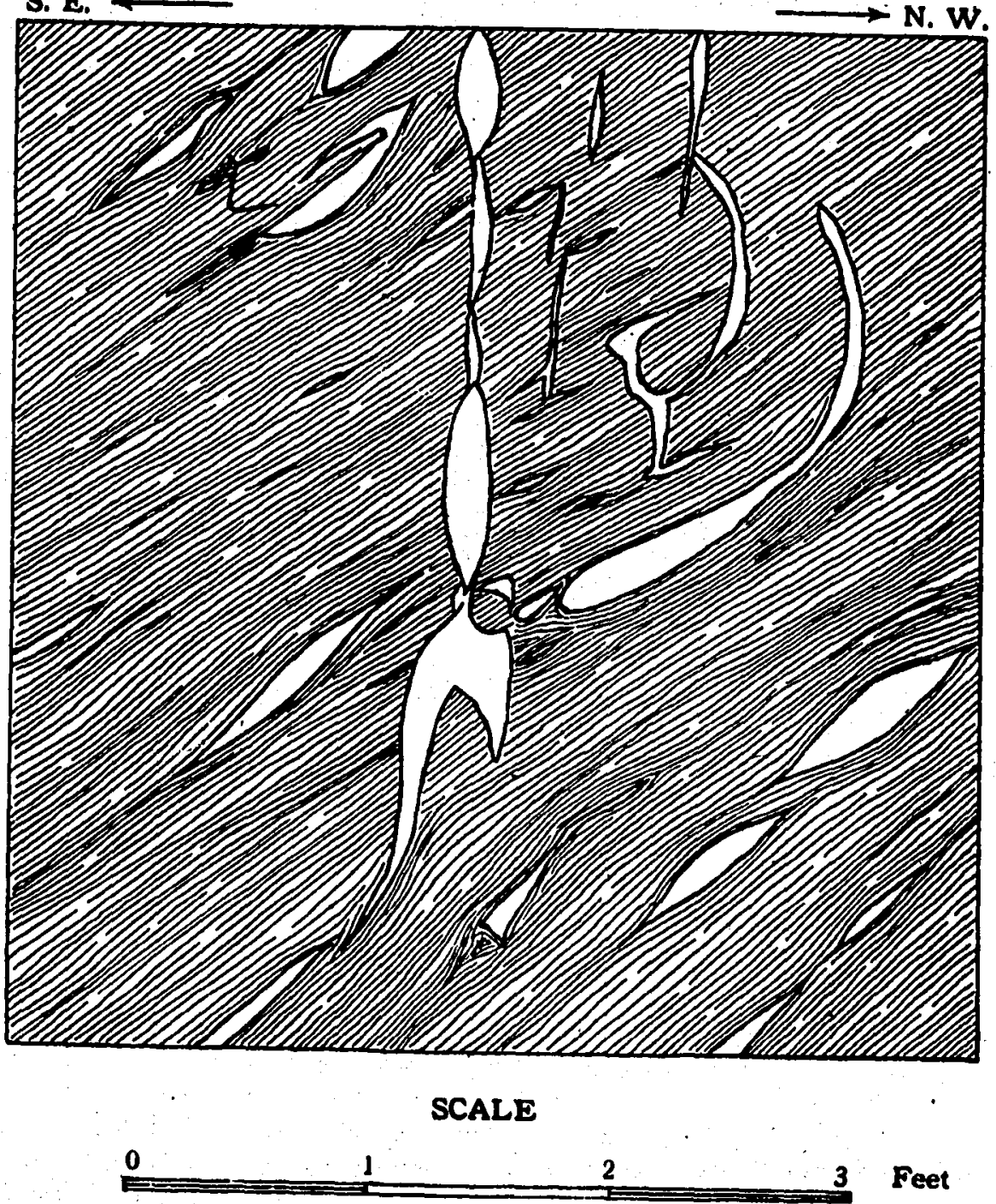

Fig. 11.-Sketch showing distribution of vein quartz, Young American mine.

The size of the hornblende crystals seems to vary somewhat with the width of the veinlets with which they are in contact, and along some of the larger veinlets they are $1 \mathrm{~cm}$. in diameter, while prismatic crystals of tremolite, which is also present, measure as much as 2 
cm. in length. Tremolite is frequently abundant near the quartz-feldspar stringers, sometimes being roughly segregated into bands, but does not appear to be an important constituent in the normal country rock. Occasionally elongated grains of a light brown mineral may be seen, which under the microscope were identified as orthorhombic amphibole.

Microscopic examination of thin sections (Specs. 499, 500, and 501) shows that the principal minerals have undergone extensive alteration, and it is not always possible to say just how much of this was due to the injection of the quartz-feldspar veins and how much is due to weathering. The hornblende is pleochroic in shades of light green, blue, and brown, and has low interference colors. The tremolite is colorless and shows rather high interference colors. In both varieties of amphibole, but especially in the hornblende, cleavage is well developed; both are ragged in outline and frequently show micropoikilitic texture; and each contains occasional inclusions of the other. Both show extensive alteration to carbonates, and chlorite, probably derived from hornblende, is also present. The carbonates in places contain small irregular fragments of amphibole, which, on rotating the stage, extinguish together, indicating that they belong to a single crystal individual. In addition to the monoclinic amphiboles there is a small amount of light yellowish-brown orthorhombic amphibole present. It occurs in elongated crystals with poor cleavage and ragged ontlines which only rarely show straight prismatic boundaries. Extinction is parallel to the elongation and the refraction." and birefringence are moderate. Quartz occurs in clear irregular anhedra which sometimes contain numerous liquid and gas inclusions. The feldspars usually show fine albite twinning, and some are also twinned according to the pericline law, while others show no visible striations. The index of refraction averages about the same or slightly higher than quartz, indicating that they are chiefly andesine or oligoclase-andesine. Orthoclase is rare if present, and has probably been entirely altered to sericite. Some of the feldspars show alteration to calcite. Sericite is rare except in lightcolored bands which are composed almost exclusively of this mineral. It occurs in long flakes or scales which usually show good cleavage, and is secondary after both cyanite and feldspar. In places a little unaltered cyanite can be distinguished in the slides, but it has almost entirely gone over to sericite. The iron ores-pyrrhotite, pyrite, and magnetite-are plentifully distributed throughout the slide, but are more abundant in the areas of dark-colored minerals. The magnetite is frequently idiomorphic, and the sulphides in places surround the magnetite. A little biotite, light 
brown to greenish-brown in color, is occasionally present in small disseminated flakes.

In the partly decomposed gneiss exposed by the adits, there are numerous slickensided surfaces stained black with manganese, probably in the form of wad. Some of these surfaces are very large, covering an area of at least several square yards. As a rule they conform in strike and dip to the schistosity of the formation, and they are common along the walls of the quartz veins. Similar slickensided surfaces occur in the workings on the "Sulphur" vein, but they were not found in the lower openings where the rock is unaltered by weathering. Because of their localization in the weathered material it is believed that these slickensides are due to changes in volume resulting from decomposition.

\section{The Belzoro Mine.}

Location.-The Belzoro mine, consisting of about 374 acres, is located 6 miles northeast of Columbia and three-quarters of a mile north of Lantana. The veins on this tract evidently belong to the same system as the "House" vein on the property of the Young American mine (see pp. 134-139), which adjoins the Belzoro on the northeast.

History $=$ Mr. Hamilton states that "the antiquity of the Belzoro mine is evident from the fact that crucibles, made by the Indians, or perhaps some remoter and unknown tribes, have been found on it, bearing a rude resemblance to an acorn cup, and manifestly devoted to the use of melting the precious metals," but in this belief he is probably mistaken. No articles of Indiain manufacture made from gold have been found in Virginia, and students of the North American Indian are generally agreed that he was ignorant of the art of melting metals. The so-called crucibles were probably used for some other purpose and doubtless were brought from the Indian soapstone quarries 3 miles northeast of this property, which are described on pages 170-171.

Gold was discovered on the Belzoro tract by surface washing in 1832, at which time the property belonged to $\mathrm{Mr}$. William Southworth. The placer gravels are said to have been very productive, $\$ 30,000$ having been recovered from a limited section known as "Dry Gulch." Bed rock was 1 to 6 feet below the surface and many nuggets weighing from 4 to 7 pennyweights were found. ${ }^{\circ}$ The work of washing gold from the gravels conaHamilton, J. R., The Natural Wenlth of Virginia, Harper's Magazine, 1805, .
vol, xxxii, pp. 32-42.

bSnell, P. A., From a report on the Belzora mine.

cHamilton, J. R., Op. cit. 
tinued with varying success up to 1849 , when the property was sold to Mr. Geo. Fisher.

Several shafts were sunk to depths 30 to 60 feet and many surface cuts and pits were opened. A 10-stamp mill was built to treat the ores which are said to have yielded as high as $\$ 300.00$ per day, but all mining operations were interrupted by the Civil War. After the close of the war a little work was done from time to time, but the mine has remained idle since the mill burned some years ago.

Descriplive geology.-There are no outcrops on the property and very little float rock aside from vein quartz can be found. The old workings have caved and are now inaccessible, but information obtained elsewhere in the vicinity confirms the data collected on the property and indicates that the country rock consists of a series of quartzose gneisses and schists varying somewhat in composition. A number of large pieces of float were found near the branch where it is crossed by the road a short distance northenst of the house. This rock is a light gray, slightly banded gneiss composed for the most part of quartz, white mica and feldspar, with a little dirk mica and magnetite. A detailed petrographic description is given on page 39. While the rock was not found in place at this point it does outcrop beyond the limits of the property in both directions along the strike and is probitily the dominant rock type in this yicinity. 'The ferruginous quartzite found on the Webb place (see pp. 19-20) also continues on this property. 'ilse veins are said to be enclosed in light-colored quartz-sericite schists (the talcose slate described by some of the early writers).

According to $P$. A. Snell there are two well-defined veins on the property 300 yards apart, one averaging from 2 to 3 feet in width, and the other from 3 to 4 feet, while the course of both is northeast and southwest and the dip $45^{\circ}$ toward the southeast, approximately parallel to the strike of the country rock. The two principal veins are paralleled by a large number of flat lens-like ore-bodies varying from 1 to 6 inches in width which are not continuous for any great distance, but pinch out and start in again a little to one side or farther along the strike. ${ }^{a}$

The ore is described as quartz carrying iron pyrite which is largely oxidized near the surface, and on either side of the veins there is said to be a narrow selvage of clay and grit (probably kaolin from the decomposition of feldspar), which is quite rich in gold, the latter showing plainly

aSnell, P. A., Op. cit

Credner, H., Report of Explorations on the Gold Fields of Virginia and North.. Carolina, Amer. Jour. Mng., 1808, vol. vi, p. 393. 
on panning a little of the material. This description indicates a type of ore-deposit similar to the lenses that parallel the "House" vein on the property of the Young American mine described in detail on pages 134-139.

These small lenses were worked entirely by open cuts and the ore obtained was washed through sluices or rockers to separate the free gold in the soft material (kaolin), which varied in value from $\$ 2$ to $\$ 20$ per ton. After the fine material was washed awny the balance consisting of coarse quartz was put through the mill to recover the gold that it contained.

Production.-Mr. Snell believes that about 2,000 to 2,500 tons of ore have been milled, this being derived mostly from the two principal veins but partly from the open cuts on the small lenticular ore-bodies. The property is estimated to have produced from placer gravels and from veins a total of not less thạn $\$ 100,000$. $^{\text {a }}$

\section{The Collins Mine.}

The Collins mine is situated on the east side of the Belzoro property 1 mile northeast of Lantana. It was probably the first mine worked for gold in this district if not in Virginia. Gold was first found in the branch crossing the property, and while the exact date of the discovery is not known, it must have been prior to 1830 . The Fishers made preparations to work the gravels, building dams across the branch and installing rockers, but before operations were actually under way they turned the property over to Steveu Collins and began work on the Busby branch instead. Mr. Collins washed the branch gravels successfully for several years, and later gold-bearing gravels were found 30 or 40 feet above the branch on the north side. Sluice ways were cut from the bottom of the hill and the gravel worked by hydraulic mining. Little if any vein-mining was ever conducted on the property.

In addition to the mines described above gold has been reported on a number of properties in the vicinity of Lantana, and a little prospecting has been done at several places, chiefly for placer gold. On a property lying south of the Belzoro mine and formerly known as the Marks mine, surface washing was commenced in 1830 by Woodfork and continued for some time by various owners. Other placer mines which have been operated at various times in this neighborhood were known as the Eades, Big Bird, and Laury mines.

\section{The Morgan Mine.}

The Morgan mine is located just west of the property belonging to the Young American mine. The placer gravels on this place were early

aSnell, P. A., Op. cit. 
worked for gold and later some vein mining was done. According to Credner the main vein is 4 feet wide. and a smaller parallel vein in the hanging wall was also worked. Before the war, ore was hauled to the Belzoro mill and is said to have yielded 70 pennyweights of gold per day, or about $\$ 3,000$ in eight months. ${ }^{a}$ Later a 10 -stamp mill was built but the size of the tailings pile indicates that little ore was milled. At present nothing remains of the mill and the old shafts and pits are completely caved.

\section{The Grannison Mine.}

The Grannison mine is situated on the west side of Camp Branch, a mile northwest of Lantana and a mile south of Caledonia. The placer gravels were extensively and successfully worked during the period that preceded the Civil War, and 3 quartz veins were opened up. . One of these was worked to some extent by open pits and a shaft 42 feet deep. After the war the veins were reopened and a 10-stamp mill built near the branch, but at present the mill is in ruins and all of the old workings caved. Most of the work seems to have been done a short distance northeast of the mill where there is a series of old shafts and pits extending for about 150 yards in a direction $N .45^{\circ} \mathrm{E}$. There are several pits located a quarter of a mile north, said to have been opened on a smaller vein which was very rich.

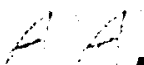

\section{Atmore, Kent, and Other Properties.}

On the Atmore and Kent properties, lying southwest of the Grannison mine, several veins have been explored and a little mining done, but all of the work has been of a superficial nature. Small veins have been prospected on a number of other places in this vicinity, but aside from placer washing practically no mining has been attempted. Nearly all the gravels along Camp Branch and some of the smaller branches that enter it have been washed for gold.

\section{The Bertha and Edith Mine.}

Location.-The Bertha and Edith mine is situated on the east side of Big Byrd Creek in Goochland County, 3 miles northeast of Columbia.

History.-The placer gravels along the branches were first worked prior to the Civil War, and the Maple and Camp branches which flow through the property are said to have yielded much gold. In $187 \%$, the Bertha and Edith Gold Mining Company bought the mineral rights and began

aCredner, $H_{\text {, }}$ Report of Explorations on the Gold Fields of Virginia and North Carolina, Amer. Jour. Mng., 1869, vol, vii, pp. 26-27. 
development work on the quartz veins. A little later a Fraser and Chalmers 20-stamp mill was erected to crush the ore and recover the gold. In 1882, the Tagus Mining and Milling Company, which was operating the Gilmer (Young American) mine, 4 miles northeast, obtained a lease and option on the property and began work. During this lease some hydraulic mining was carried on, water being furnished under pressure by a large pump and the gravel washed through sluice boxes. Several veins were prospected by surface openings but most of the underground development was limited to the "Oak Hill" and "Maple Branch" veins. The "Oak Hill" vein was explored by an adit 400 feet long, which drained the hill 75 feet below the summit and was connected with an upper level on which there were 300 feet of drives and cross-cuts. ${ }^{a}$. The "Maple Branch" vein was explored by a tunnel, but work had to be stopped on account of bad ground.

In 1897, the Rivanna Gold Mining Company reopened the "Oak Hill" vein and built a cyanide plant to treat the tailings from the stamp mill. Milling had scarcely begun before the whole plant was destroyed by fire in 1898, and since that date no work has been carried on. While the "Oak Hill" vein was being reopened the company prospected the placer gravels in the flat near the mouth of Camp Branch and started to work the deposits, the method being to first remove the overburden with scrapers and then wash the gravel in rockers, but this was discontinued when the mill burned. At the present time the shafts are partly caved and all the underground workings are inaccessible.

Description of veins and country rock.-The country rock in which the veins are located consists chiefly of schists and gneisses of sedimentary origin, and their contact with hornblendic border facies of the granite is only about half a mile southeast of the "Oak Hill" vein. The dominant rock in the sedimentary series is a medium-grained gneiss composed essentially of quartz, sericite, and feldspar in the order named; with a little biotite and a few grains of magnetite. This is the only rock outcropping on the property excepting along the bluffs that border Big Byrd Creek where quartz-sericite schists and hornblende schists occur in places.

The "Oak Hill" vein varies up to 6 feet in width and is said to have averaged about 3 feet. Ore found on the dump consists of ordinary vein quartz containing considerable fine-grained pyrite, which is partly oxidized to limonite, and on crushing and panning it shows fine grains and scales of free gold. Some of the pieces show a little white mica and kaolin un-

aHotchkiss, Jed, Virginia Minerals for the New Orleans Exposition, The Virginias, 1884, vol. $v$, p. 166 . 
donbtedly derived from feldspar. A little magnetite is occasionally present. The ore from this vein is said to have averaged a little over $\$ 5.00$ per ton: The "Maple Branch" vein has a northeast-southwest strike and is said to be much narrower but richer in gold than the "Oak Hill" vein. Miners, who worked on the property when the openings were made, state that this vein carried a large amount of white kaolin. The "House" vein, situated about a quarter of a mile northwest of the other two, has been worked to a limited extent, but nothing definite could be learned concerning it. Float rock picked up on the surface nssayed as much as $\$ 32.75$ per ton. There are some placer gravels remaining on the property that have never been worked (see pages 239-240).

\section{The Pryor Tract.}

The Pryor property is located 11/2 miles southeast of Tabscott and lies south of the Busby mine. The placer gravels along Busby Branch, which crosses this property, were worked soon after the first discovery of gold in the district. Recently several small shafts have been sunk on the property in the hope of locating the "Waller" vein, but, so far as is known, nothing of value was found.

\section{The Moss Mine.}

Location.-The Moss mine is located on the south side of the ColumbiaTabscott rond, about 8 miles northenst of Columbia and 11/2 miles southwest of Tabscott.

History.-The Moss vein, on which most of the work has been done, is said to have been discovered in 1835 by John Moss. ${ }^{a}$. Prof. Silliman, ${ }^{b}$ reporting on the property in 1836, found the mine developed by two incline shafts sunk on the vein; one measuring 31 feet along the slant and having a vertical depth of 25 feet, while the other was 50 feet deep, though the lower 20 feet was inaccessible at the time of his visit. The two shafts were connected by an adit 70 feet in length and the vein was exposed throughout the length of these workings. Measurements taken at intervals along the vein ranged from 16 to 30 inches in width and averaged about 24 inches. The inclination, about $45^{\circ}$ toward the southeast, and the strike, about north by east and south by west, were conformable with the stratification of the inclosing slaty rocks. A sample was taken by knocking off pieces of ore at intervals of 12 feet along the vein and this, after being

aNitze, H. B. C., and Wilkins, H. A. J., Gold Mining in North Carolina and Adjacent South Appalachian Regions, Bull. 10, N. C. Geol. Survey, 1887, p. 75.

bSillimnn, B., Remarks on Some of the Gold Mines and on Parts of the Gold Region of Virginia, Amer. Jour. Sci., 1837, vol. xxxii, pp. 98-130. 
broken down and subdivided to give a final sample of 9 pounds, was washed and amalgamated; the button of gold recovered in this manner weighed 11 grains, giving the ore a value of about $\$ 105$ per ton. In another trial Prof. Silliman obtained 6 grains of gold from $31 / 2$ pounds of powderec rock in which no gold was visible, and in a third experiment two pounds of ore yielded 5 grains of gold.

Credner states that the Moss mine was worked from 1836 to 1838 by a company ('The Richmond Mining Co.) whose shares rose in a year's time from $\$ 5$ to $\$ 300$, but fell as quickly to nothing. ${ }^{a}$

The mine was reopened in $\mathbf{1 8 9 1}$ and tests made on the ore with a 3 -stamp prospecting mill, ${ }^{b}$ and during 1904 the property was operated under lease by the Telluric Gold Mining Company. At this time the mine was developed by 2 main shafts, known as No. 1 and No. 2. 'The No. 1 shaft was sunk on an incline to a depth of 118 feet, and levels run enst and west a total distance of 285 feet in ore milling $\$ 15$ per ton. In the west level a small shoot was encountered which averaged $\$ 150$ per ton in gold, and 40 ounces in silver. The No. 2 shaft was carried to a depth of 130 feet and levels driven 60 feet east and west along the vein, the ore developed milling $\$ 14.40$ per ton. A 3-stamp battery was added, giving the mill a total of 6 stamps. Regular assays of tailings indicated an average of $\$ \$ 2.00$ per ton.

Descriplive geology-The vein is said to consist of laminated quartz lying in more or less lenticular masses between walls of micaceous slate. Pieces of the ore examined by the writer are in the form of thin plates 0.5 to 1 inch thick, and broken along joint planes spaced 5 to 9 inches apart. Coarse gold, in grains about $0.5 \mathrm{~mm}$. in diameter, is sprinkled along the surfaces of the laminæ, a little pyrite mostly altered to limonite is present, while flakes of white mica and considerable kaolin, probubly derived from feldspar, were also noted. Black tourmaline is said to have been common in some of the ore and prisms of this mineral were found in a number of pieces of float on the surface.

Specimens found on the shaft dumps indicate that the wall rock is a dark gray schist with slaty cleavage, composed for the most part of fine-grained quartz and biotite, varying somewhat in their relative propoitions but with the quartz always largely in excess. A few small black needle-like prisms

aCredner, H., Report of Explorations on the Gold Fields of Virginia and North Carolina, Amer, Jour. Mng., 1869, vol. vii, p. 27.

bEng. and Mng. Jour., 1001, vol. lii, p. 108 .

oFroehling and Robertson, A Hand-Book on the Minerals and Mineral Resourees of Virginia, 1004, pp. $51-52$. 
of tourmaline or hornblende are also present. The soft running ground which is reported to have given much trouble in shaft sinking, was probably due to disintegrated schist of this character saturated with water.

Pieces of hornblende schist were also found on one of the dumps. This is a greenish-gray, medium-grained rock composed of dark green hornblende in crystals ranging up to 2 or $3 \mathrm{~mm}$. in diameter, fine-grained, white quartz and feldspar, and numerous pink garnets, usually less than $1 \mathrm{~mm}$. in diameter. In thin section under the microscope the hornblende is light green in color, very ragged in outline, and micropoikilitic from numerous inclusions of quartz and feldspar. Quartz, the second mineral in relative abundance, frequently contains inclusious of broken zircons, and gas- and liquid-filled cavities. The feldspar is plagioclase, probably andesine, and in places shows albite twinning though this is usually absent. The large, light pink garnets which are plentiful in the slide are often ragged in outline and contain many included quartz grains. Chlorite, partly derived from garnet but mostly from the hornblende, is present in light green flakes. A very little biotite, scattered grains of magnetite, and some pyrite, partly altered to limonite, make up the minor accessories. In the absence of a chemical analysis or data bearing on the structural relations of this rock it is impossible to state whether it is igneous or sedimentary in origin, but the writer is inclined to the latter alternative.

An old shaft; partly caved, which is located close to the county road is said to have been sunk to cut the Hodges vein. Partly decomposed garnetiferous mica schist is exposed on the dump.

\section{The Busby Mine.}

The Busby mine lies $81 / 2$ miles northeast of Columbia and 1 mile southwest of Tabscott, joining with both the Moss and Bowles properties. It was one of the first gold mines in the' State to be worked, the placer gravels on Busby Branch having been washed by the Fishers as early as 1829 or 1830 . In working up the branch, the Busby vein was discovered, and then a small wooden stamp mill run by horse-power was put up by the Fishers and D. W. K. Bowles.

In 1836, when Prof. Silliman ${ }^{a}$ visited the district to report on the Moss and Busby mines, they were being developed by the Richmond Mining Company. A shaft had been sunk to a depth of $5 \%$ feet with the

aSilliman, B., Remarks on Some of the Gold Mines, and on Parts of the Gold Region of Virginia, founded on personal observations made in the months of August and September, 1836, Amer. Jour. Sci., 1837, vol. xxxii, pp. 88.130. 
expectation of striking the vein at 70 feet, the vein having first been proved by 4 prospecting pits 20 to 26 feet in depth. These openings showed the vein to be from 12 to 30 inches wide, averaging 15 to 18 inches. The rein quartz, as described by Prof. Silliman, has a coarsely granular texture with a strong resemblance to coarse lump sugar, much of it being white and apparently free from all foreign matter other than the inherent gold. A 6-pound sample picked at random from a large pile was crushed, washed, and the gold amalgamated with mercury; upon retorting it yielded 6 grains of gold worth $41 / 12$ cents per grain. This is equivalent to over $\$ 81$ per ton. A picked sample containing small points of visible metallic gold, when treated in the same way, yielded 6 grains of gold from 2 pounds of ore, or about $\$ 250$ per ton.

Notwithstanding the reported value of the ore, comparatively little mining seems to have been carried out on the property, and when it was visited by Credner in $\mathbf{1 8 6 5}$ the mill was in ruins. ${ }^{a}$ He states that the continuation of the Moss vein was exposed by 4 shafts the first and last of which were one mile apart.

When visited by the writer in 1910 the shafts had caved so that few observations could be made. Several old pits are located about 50 yards north of the Columbia-Tabscott road and in line of strike with the Tellurium vein system. On the dump of one of these openings pieces of quartzite werc found identical in appearance with the material from the "Big Sandstone" vein, but whether it has been mineralized at this point or not, could not be determined. About 100 yards south of the road a small pit had been sunk, apparently on a ferruginous quartzite similar to that known as the "Hodges" vein at the Scotia mine.

\section{The Payne Traot.}

The Payne tract is located on the south side of the county road half a mile southeast of Tabscott. It adjoins the Busby mine and was formerly a part of that property. There are a number of old surface cuts and caved shafts which extend in a line running about N. $58^{\circ} \mathrm{E}$. A large pile of mill tailings a short distance below the openings indicates the site of the old mill of which no other trace remains. The mill that Credner found in ruins when he visited the Busby mine was probably located at this point. In 1911 an attempt was being made to reopen one of the old shafts.

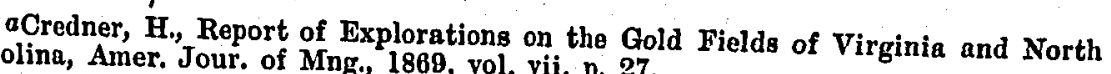




\section{The Waller Mine.}

Location.-The Waller mine is situated in Goochland County half a mile southenst of 'Tabscott and about 10 miles northienst of Columibia, the nearest railroad station.

History.--The Waller mine was discovered in 1831, and during that year Cole and Woolfork carried on surface washings for several months. Veins were discovered by Moss in 1832, and a vein 6 feet thick is said to have been opened by, the Fishers and worked until the lavd was purchased by Wm. K. Smith. Later it was sold to Richards, of New York, who worked the mine 12 months and then sold it to an English compuny for a large sum. After two years, during which it is said to have been badly managed, the property was divided and sold in two parts. Since that time only the western part of the old estate has been known as the Waller mine. In 1865, Turner, Hughes \& Co. sank a shaft and did some development work, but since that date nothing has been done, aside from 30 days' work in 1876, until the present company began operations in 1910. ${ }^{a}$ During the latter year a shaft was sunk to a depth of 72 feet and two cross-cuts driven northwest at depths of 45 and 60 feet, respectively. A small vein, said to be the Waller vein, was encountered in the 60-foot cross-cut, but the drive which was started southeast along the vein soon ran into old workings. Another shaft was started in 1911 to strike the vein at greater depth, but when the property was visited in the summer of that year the vein had not been reached. A small mill is said to have been operated on the property in the early days but no trace of it remains to-day. Before the property was divided, veins belonging to the Tellurium system which crossed the northwestern portion of the property were also developed to
some extent.

Descriptive geology.-The mine is situated in an area of schists and quartzites not far from their contact with the hornblendic border facies of the granite, which is found outcropping a short distance southwest of the property. Because of lack of exposures it is not possible to accurately locate the contact at this point, but many pieces of hornblende schist were found on the surface within less than 200 yards southwest of the vein. About a quarter of a mile northeast of the vein a small pit was sunk in prospecting for iron. The material encountered seems to have been a ferruginous quartzite similar to that found elsewhere in the district. About half a mile northwest of the mine occurs the same series of quartzites and schists found at the Tellurium mine.

aMost of the facts stated above were taken from "The Natural Wealth of Virginia," by J. R. Hamilton, Harper's Magazine, 1865, vol, xxxii, pp. 32-42. 
The strike of the Waller vein at the surfnce, as indicated by the old open cuts and caved stopes which extend for about 300 yards along the outcrop, is $\mathrm{N}$. $58^{\circ} \mathrm{E}$. When the mine was examined by the writer, the vein was exposed for a distance of only 25 feet along the strike at a deptl of 60 feet below the surface. At this point the dip was about $40^{\circ}$ towarl the southeast and the strike $\mathrm{N} .60^{\circ} \mathrm{E}$. The width of the rein where it could be nensured ranged from 4 inches down to less than an inch, and .was composed for the most part of quartz, feldspar, more or less knolinized, and a little limonite resulting from the alteration of pyrite. The relative proportions of these constituents varied grently; where widest the vein consisted almost entirely of white vitreous quartz, but in most places feldspar was abundant, and in some of the narrower portions was dominant. The limonite was commonly mixed with kaolin and quartz to give an earthy, yellowish-brown material, which often contained much coarse gold.

The textural relations of the quartz and feldspar are similar to those of a typical pegmatite and in places there is a suggestion of graphic intergrowths. The feldspar individuals range up to $1 \mathrm{~cm}$. or more in diameter, and in the wider portions of the vein are more or less concentrated nenr the walls. The gold when visible occurs in irregular grains and rough wire-like masses, some of which measures $3 \mathrm{~mm}$. in length, and is usually associated with decomposed earthy material heavily stained with limonite. Specks of gold may occasionally be seen in feldspar and clear, unstained quartz, and more rarely in the wall rock close to the vein.

Microscopic eximination of the vein rock in thin section (Spec. 217) shows no accessory minerals other than a little sericite derived from the feldspars. The quartz is nearly free from optical distortion and contains numerous gas- and liquid-filled cavities. These cavities occur partly in irregular branching and interlaced forms, and partly in smaller spherical and elliptical shapes which are usually grouped in rows and planes. In places the inclusions are so small and plentiful as to give the quartz a clouded appearance even under a magnification of 200 diameters. The feldspars are extensively kaolinized and show some alteration to sericite, but apparently consist entirely of acid plagioclase (albite-oligoclase to oligoclase). ${ }^{a}$ Twinning after the albite law is common, though much of

aDr. E. S. Larsen, Jr., using the immersion, method, determined these feldspars to be albite-oligoclase to oligoclase and states that the fresher crystals appear to be oligoclase. The indices of refraction as determined by him are:

$$
\begin{aligned}
& x=1.535 \pm 0.003 \text { to } 1.538 \pm 0.003 \\
& r=1.543 \pm 0.003 \text { to } 1.547 \pm 0.003
\end{aligned}
$$


the feldspar is unstriated. A photomicrograph of some of the striated feldspar is shown in Pl. VIII, fig. 2. The narrow veinlet crossing the feldspar is composed of quartz.

The wall rock is fine-grained and badly decomposed, so that it is very difficult to obtain specimens fresh enough for identification. The rock exposed on the hanging wall side of the vein is dark blue in color and consists essentially of quartz and magnetite in grains that are too small for sight determination. For a distance of 3 feet or more from the vein there are numerous veinlets composed of quartz and feldspar, which range. from an inch or more in thickness down to threads and lenses microscopic in size, and which are approximately parallel to the main vein. Limonite and iron-stained cavities due to the oxidation of pyrite occur in places, and there is probably some gold, for these veinlets appear to be essentially the same as the vein in which gold was identified. Small flakes of biotite usually occur along the contact between the veinlets and the country rock, and the mica is plentiful along both walls of the principal vein. The rock on the foot-wall side was not as well exposed. Where it could be examined it was much weathered, but appeared to consist of biotite, kaolinized feldspar, and quartz. Pieces of rock from the hanging wall sometimes contain smáll, light brown crystals, often radiating, which resemble sillimanite, but are too small and too much decomposed for positive identification.

A thin section (Spec. 219) of the hanging wall rock was also examined under the microscope. It is schistose in structure and consists of a finegrained ground-mass of quartz, magnetite, and a little feldspar, in which there are numerous small irregular lenses and veinlets composed of coarser grained quartz and feldspar. The quartz grains in the ground-mass show wavy extinction, the magnetite is present in idiomorphic grains, and the feldspar, which seems to be chiefly acid plagioclase, is more or less kaolinized. The quartz in the lenses shows no optical distortion, and frequently contains numerous small fluid-filled cavities. Many of these cavities contain rapidly vibrating bubbles. A little zircon and titanite are also present as inclusions in the quartz. Feldspar is not very plentiful, and is chiefly concentrated along the border portions and at points where the lenses pinch out. Most of the feldspar crystals show Carlsbad twinning and are probably orthoclase, but a little acid plagioclase is also present. 
On the surface nenr one of the old openings pieces of vein rock were found which consist of intercrystallized quartz and calcite. The calcite is coarsely crystalline, has curved cleavage surfaces, and contains much iron and a little magnesium. Dark green hornblende partly altered to chlorite and a little pyrrhotite are also present in the calcite and along its margins. Other pieces of rock on the old dump have a banded structure and are composed of alternating layers in which the dominant minerals are, respectively, coarsely crystalline, dark green hornblende and white finer-grained calcite. Lenses of quartz occur in places and there is a little pyrrhotite and some pyrite present.

\section{The Fleming Mine.}

Location.-The Fleming mine is situated in Goochland County about a mile northeast of Tabscott and on the southeast side of the county road.

History and description.-The placer gravels on this property are saicl to have been washed during the early days of gold mining in the district. Underground work was started by General Cook in 1846 and a 6-stamp mill operated by him is said to have yielded on occasions as much as $\$ 200$ per day. This, siccess, however, was short-lived as the vein was soon lost. At this time tivo shafts were sunk to depths of 60 and 35 feet, respectively. During its early history the property was known as Hodge's mine; but in 1848 it was sold to the L'Aigle d'Or Company of New York. ${ }^{a}$ Little development work was attempted until after the Civil War, when the mine was reopened by several small shafts, and since that time it has been known as the Fleming mine.

When the property was visited in 1910 all of the openings were inaccessible; a series of old pits and shafts was' seen' extending in a direction N. $60^{\circ}$ E. for about 150 yards, and in one of the shafts decomposed schists were exposed having a strike of N. $61^{\circ}$ E. and a dip of $45^{\circ}$ toward the southeast. A few pieces of vein quartz were found on the dump, but they showed little evidence of mineralization.

\section{Shannon Fill.}

Shannon Hill is the most northeasterly point within the area where gold has been found. Some prospecting was carried on here years ago,

"Credner, H., Report of Explorations on the Goll Fields of Virginin and North Carolina, Amer. Jour. Ming., 1869, vol. vii, p. 20. 
but nothing further seems to have been done. Credner examined the property in $\mathbf{1 8 6 5}$ and states that a lode, 1 to 3 feet wide and paralleled by two smaller veins, was exposed by surface pits. The strike is given as N. N. E. and the dip $40^{\circ}$ to the east. The veins are said to consist of white translucent tabular quartz with a great deal of earthy oxide of iron and some gold. Garnetiferous micn schist outcrops in the road at Shannon Hill, having a strike of N. $45^{\circ}$ E. and a dip of about $45^{\circ}$ southeast. While considerably decomposed it is apparently similar to the wall rock at the Tellurium mine and probably represents the same formation. Placer gravels were washed on this property before the Civil War and considerable gold is said to have been recovered.

\section{The Benton Mine.}

Location.-The Benton mine is located in Goochland County about three-quarters of a mile northeast of Talsscott and on the northwest side of the county road.

Description.-This property was explored by a shaft, now inaccessible, and the size of the dump indicates that it reached a considerable depth. The country rock found on the dump is a garnetiferous schist similar to the wall rock at the Tellurium mine, and pieces of vein quarti were seen that contained a little kaolinized feldspar and some white mica. The property is in direct line of strike with the Tellurium system of veins, and this fact together with the material found on the dump indicates that the vein is similar in its general characteristics to those described under that mine. 'There is a number of old pits and caved shafts between this point and Tabscott, which were probably sunk in prospecting the same vein or others belonging to this system, but the openings are so old that the material on the dumps lias completely disintegrated, and therefore no definite information could be obtained concerning the exposures. A few pieces of massive diorite, cvidently derived from some dike, were found on the surface. The rock is described in detail on page $\mathbf{8 5 .}$

\section{The Tellurium Mine.}

Location.-The Tellurium mine, locnted $71 / 2$ miles northenst of Columbia and $21 / 2$ miles southwest of Tabscott, lies partly in Fluvanna and partly in Goochland counties. 
Hislory and description.-It was one of the first properties in Virginin on which vein mining for gold was attempted, and its history differs from that of most mines in this section in that the veins were discovered and worked before the placer gravels. The first discovery on the place was made in 1832 by G. W. Fisher while hunting, and in 1834 the property was leased from its owner, Mr. Hughes, by Geo. Fisher, his two sons, G. W. and J. A. Fisher, and Judge D. W. K. Bowles.

At first the ore was raised and crushed by hand, and the gold separated from its gangue by washing in a box. The crushing was carried on in wooden mortar's lined with iron, the heavy pestles being attached to sweeps which were likewise operated by hand. Later an arrastra driven by horsepower was installed, and finally a small stamp mill was built on the branch about one mile below the mine. This was probably the first stamp mill, or "pounding mill" as they were originally called, to be erected in this country, and it is supposed that the innovation was derived from Europe. According to Nitze and Wilkins, ${ }^{a}$ a 6 -stamp mill was in operation at the Tellurium mine as early as 1836. The ore was crushed on an iron die plate by 50-pound wooden stamps with iron shoes; the stamp stems were square and did not revolve as in later mills, for the cams worked in slots cut into the stems.

The mine was! in continuous and profitable operation for 14 years under the Fisher-Bowles lease, and during that period the work was confined to the "Little" and "Middle" veins which are said to have been the richest, but very little authentic information regarding the production or the value and character of the ore is obtainable at this date. The "Little" vein is said to have averaged less than a foot in width and the deepest workings were only 65 feet, though as a rule the vein pinched out before this depth was reached. According to G. W. Fisher 100 pounds by weight of the richest ore ever obtained from this vein, on crushing and washing, yielded 210 pennyweight of gold. ${ }^{b}$ The "Middle" vein is said to have averaged $11 / 2$ to 2 feet in width but the ore was not so rich as the "Little" vein.

Dr. Gray, in a letter to Dr. Thomas Pollard, gives the average value of the ore obtained from the two veins during this 14 -year period as $\$ 100$ per ton. Prof. B. Silliman visited "Fisher's or Hughes' mine," as the property

aNitze, H. B. C., and Wilkins, H. A. J., Gold Mining in North Carolina and Adjacent South Appalachian Regions, Bull: 10, N. C. Geol. Survey, 1807, p. 35.

uStatement made to the writer by R. H. Fisher, nephew of G. W. Fisher.

oHotchkiss, Jed., The Tellurium Mine and Virginia Gold Mining, The Virginias, 1881 ; vol. ii, p. 85 .

Pollard, Thomas, The Gold Belt of Virginia in "Gold, Its Occurrence and Extraction," by A. G. Locke, New York, 1882, pp. 182-190. 
was variously called at that time, in $183 \%$, and quotes $\mathrm{Mr}$. Fisher as saying, that the average value of the ore was $\$ 3.15$ for every 100 pounds, while the cost did not exceed 30 to 35 cents per hundred pounds. ${ }^{a}$ According to local report, the lessees paid a royalty of 10 per cent. of the gold, recovered, and during the period of the lease Mr. Hughes received as lis share $\$ 13,000$ or $\$ 15,000$, the accounts differing as to the exact amount, making a total production of $\$ 130,000$ or $\$ 150,000$.

In 1848 , the property was bought by Commodore R. F. Stockton, who erected a 40-stamp mill and proceeded to work the mine on a larger scale. His operations extended over a period of about 9 years, and then the mill was burned to the ground. The "Middle" and "Little" veins were worked to a limited extent, but most of the mining was confined to the so-cnlled "Big Sandstone" vein, which averaged about 3 feet in widtl and in places reached 6 feet or more. The deepest shaft was sunk in the hanging wall about 300 feet from the outcrop and is reported to have reached a depth of 136 feet, but the other openings would not average 45 feet, and practically all of the ore came from above the water level. Starting from a small branch that crosses the outcrop, a tunnel was driven along the vein, and nearly all the stoping was above this level. These old workings are now mostly caved, but they can be traced across the property on the surface for a distance of about 1,500 feet along the strike.

Many remarkable tales cluster about the name of Commodore Stockton and the fortunes said to have been made by him in Virginia gold mines, but few of these can be verified. Estimates of the gold extracted by him from the Tellurium veins vary from $\$ 75,000$ to over $\$ 1,000,000$, but the lower figure is probably more nearly correct.

After the mill had burned the property was sold and no further work was carried on until after the war. Since that time there have been spasmodic attempts to reopen the mine, but none seem to have been attended with any great degree of success. About the year 1880, a 10stamp mill with amalgamated copper plates was built, and for a short time the mine was operated under lease. Most of the ore mined at this time was taken from the "Big Sandstone" vein. A few years later the stamp mill was pulled down and replaced by some kind of a revolving mill, which was used to treat ores from the "Gold Hill" veins on the Bowles tract, adjoining the Tellurium on the northeast. About the year 1890, two Tremain steam stamps were installed on the property, but they were never used to any extent.

aSilliman, B., Remarks on Some of the Gold Mines, and on Parts of the Gold Region of Virginia, Amer. Jour. Sci., vol, xxxii, pp. 98-130. 
The last work done on the property was in 1909-1910, when the Argus Gold Mining Corporation cleaned out part of the old workings on the "Big Sandstone" and "Middle" veins, and sank a 3-compartment incline shaft on the "Big Sandstone" to a depth of about 90 feet measured along the dip. Drives were started in either direction along the strike of the vein, but had only progressed a few feet when the mine was closed down. One of the old 'Tremain stamps was set up again and used in testing a few tons of ore from the "Middle" and "Big Sandstone" veins.

Present underground development.-When the property was examined by the writer in the summer of 1910, the "Big Sandstone" vein was exposed by the new 90 -foot incline with short drives at the bottom, and by an old drain tunnel which had been reopened for a distance of 90 yards along the vein, and which connected with a shallow incline. The "Middle" vein was exposed by an incline shaft 50 feet deep and about 125 feet of drives along the vein, all above water level. A little stoping had been done on the latter vein. While there has been a number of other shafts and openings made at various times, they are not now accessible.

\section{The Tellurium Vein System.}

Introduction.-The geological descriptions given below will suffice for all properties located along the line of the Tellurium vein system, and under each mine only such details will be referred to as are not mentioned in the description of the system as a whole. The Tellurium system of veins has been developed almost continuously for a distance of a mile, and prospected at short intervals for 5 miles or more along its line of strike. The greatest amount of development work, however, has been done at the Tellurium and Bowles mines. The only openings accessible, when the area was studied by the writer, were located on the adjoining properties of the Tellurium arid Scotia mines; and therefore the detailed geological descriptions will be limited to these two properties; but everything that could be learned concerning development work done elsewhere along the belt, indicates that the general structural relations are everywhere the same, though the veins have proved profitable in only a limited number of localities.

General description of veins and country rock.-The veins belonging to the Tellurium system are situated in a series of fine-grained quartzmica schists, usually garnetiferous, interbedded with fine-grained, evengranular quartzites, some of which contain much hematite and magnetite. All the gold-bearing veins observed occur either in quartzite beds, which 
are very narrow, or in the schists close to them. This serics of sedimentaries is bounded on the northeast by a fine-grained granite, which in places, especially near its borders, contains areas of hornblende schist. Exposures are very rare except where-openings have been made in prospecting for veins, so it is not possible to trace the exact boundaries of the granite area, but its field relations, the lack of schistosity in most places, and the extensive metamorphism exhibited by the schists in the vicinity, indicate that it is later in origin than the sedimentaries. The granite is exposed within less than half a mile of the Tellurium veins and probably comes much closer. Specimens found on one of the old dumps at the Tellurium indicate that there are probably apophyses from the granite, if not the main mass itself, within a few yards of the veins, and this hypothesis is supported by the extreme metamorphism of the rocks at the few places where they are exposed on the northeast side of the veins.

The veins which have received the greatest amount of attention on the Tellurium property are known as the "Big Sandstone," and "Middle," and the "Little" veins. In addition to these the "Hodges" vein on the Scotia property and several other veins belonging to the system have been prospected to a limited extent.

The so-called "Big Sandstone" vein consists of a bed of quartzite 2 to 6 feet thick,; cut in places by irregular gold-bearing veinlets, composed essentially of quartz with more or less feldspar and a little pyrite. (See fig. 12.) The veinlets range up to about 1 foot in width, and in their vicinity the quartzite is often impregnated with a very small amount of pyrite, chiefly along bedding planes, and carries a little gold. This bed of quartzite is remarkably uniform wherever it has been observed, and apparently extends continuously for a distance of 3 miles and possibly farther, but it is probably gold-bearing only in places and where it has been mineralized by the vein-forming solutions. . It has an average strike of $\mathrm{N} .64^{\circ} \mathrm{E}$. and dips at an angle of about $45^{\circ}$ toward the southeast.

The outcrop of the "Middle" vein is parallel to the "Big Sandstone" and located about 30 feet southeast, dipping in the same direction at an angle of $43^{\circ}$. Where exposed it consists of a series of lenses varying from 3 feet down to a knife edge in thickness, and is composed of quartz with variable amounts of feldspar, pyrite, largely oxidized to limonite, and a little gold. The lenses are. enclosed by a thinly foliated, garnetiferous schist the folia of which conform to the flexures of the vein. (See fig. 13.)

The "Little" vein, which is not at present exposed, is said to parallel . the "Middle" vein at a distance of 20 feet to the southeast. Descriptions 
indicate that it is similar in character to the "Middle" vein but narrower, averaging less than $a$ foot in width, and richer in gold. The deepest workings on the "Little" vein are said to have attained about 65 feet from the surface, but it usually pinched out before that depth was reached.

A vein known as the "West" vein is exposed by a shaft 40 yards northwest of the "Big Sandstone" vein at the Tellurium. Where exposed it has a strike of $\mathrm{N}$. $27^{\circ}$ E., a dip of $80^{\circ}$ to the east, and is about a foot wide. Quartz found on the dump yielded colors of free gold on panning. The nonconformity of this vein in strike and dip. with the other veins of the Tellurium system, suggests that it may belong to the Gold Hill system described on pages 176-179, but the shaft was partly caved and the rein and wall rock could not be examined closely.

The so-called "Hodges" vein, developed to some extent on the Scotia property, is a lenticular bed of ferruginous quartzite, which narrows from a width of over 6 feet to a fraction of an incle within a distance of only 40 feet. The quartzite is cut by a few small stringers of gold-bearing quartz, which have mineralized the enclosing rock to a limited degree. While this quartzite pinches out and is not continuous in its course, as is true of the "Big Sandstone" bed, pieces of float similar in every way are plentiful at several points in approximate alignmeint with one another. in a northeast-soythwest direction.

At a number of localities on the Scotia, Tellurium, and other properties along the course of the Tellurium vein system, there are bold outcrops of large veins, consisting of massive white quartz carrying a small amount of knolinized feldspar. Some of these veius are 10 to 20 feet wide and can be traced for several hundred feet along the strike. They are reported to carry traces of gold but none of then have been worked.

The wonderful uniformity and persistence of the bed of quartzite, known as the "Big Sandstone" vein, and hitherto regarded as a true vein, has given rise to a mistaken iden concerning the continuity of the veins in this district. The "Little" vein and the "Middle" vein and even the goldbearing stringers in the "Big Sandstone" vein itself, are not continuous for great distances, though it is probable that sections across the vein system, at two or more points, would intersect approximately the same number of veins; for while the veins frequently pinch out, they may be replaced by others a little to one side or farther along the line of strike.

Detailed descriptions of veins and wall rock.-The sketch given in fig. 12 shows the appearance and structural relations of the "Big Sandstone" vein in the northeast drive from the bottom of the new incline shaft at 
the Tellurium mine, which is about 65 feet from the surface; and this occurrence is typical of the vein wherever it could be observed. Here the quartzite bed is 6 feet thick, and distinctly laminated parallel to the bedding, the laminæ being disturbed in places where the quartz veinlets cut across them. At the top of the bed the quartzite grades into a finegrained quartz-sericite schist, and finally into the garnetiferous schist which forms the foot-wall of the "Middle" vein; but at the bottom the contact with the underlying rock is sharp and well defined. Below the quartzite there is a bed 4 to 5 inches thick, consisting for the most part of biotite, often altered to chlorite, large garnets, and a little feldspar. The rock underlying this bed is exposed for a short distance only. It is highly laminated and finer grained, but in mineral composition resembles the rock above except for the presence of more quartz. Detailed petrographic descriptions of all of these rocks are given below.

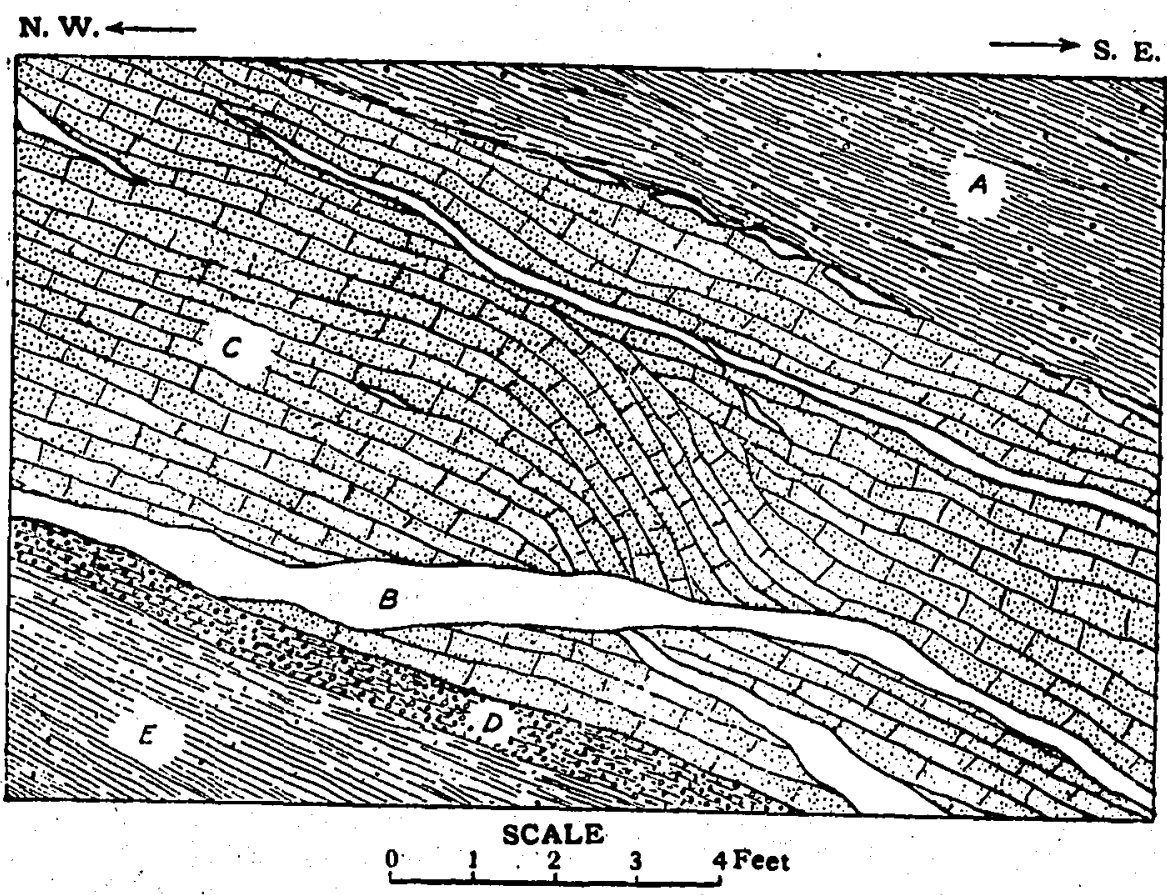

Fig. 12.- Sketch of quartzite bed cut by gold-bearing veins, Tellurium mine. A, hanging wall schist; $B$, quartz-feldspar veins; $C$, quartzite; $D$, garnetiferous foot-wall layer; $E$, foot-wall schist. 
The individual veinlets in the quartzite range up to 14 inches or more in width, and commonly follow bedding planes though they frequently cut directly across. Where the bedding planes are cut by veinlets, little spurs from the quartz sometimes extend out along them for a short distance. Lenses of vein quartz occasionally take the place of veinlets at the top of the quartzite, but rarely occur within the bed itself, and where seen were always small. The veinlets are composed essentially of white to translucent, coarsely crystalline quartz, and kaolinized feldspar is usually present, in places becoming an important gangue mineral. Pyrite is commonly a constituent in small quantity but rarely exceeds one per cent.; native gold occurs in small grains and scales that may usually be detected on panning the crushed ore ; and sphalerite, tetradymite, and tellurium (?) have been identified as rare accessory minerals. In the oxidized zone near the surface, joint planes and fractures in the quartz are frequently stained with black oxide of manganese.

The feldspar is distributed throughout the quartz veins in small angular shapes, but is more plentiful near the border portions where it sometimes forms small lenticular bands or streaks parallel to the walls, and may constitute as much as 10 per cent. of the mass. Rarely it occurs in lenticular masses 3 inches or more in maximum diameter. In most places where the vein is exposed the feldspars are completely altered to kaolin, and it is difficult to obtain specimens sufficiently fresh to admit of their determination.

The freshest feldspars were obtained from a piece of vein quartz found on a shaft dump at the Scotia mine, and which evidently came from the foot-wall side of the quartzite bed, for some of the underlying rock was firmly attached. In the hand specimen (143-A) the feldspars occur in somewhat angular individuals ranging up to $0.75 \mathrm{~cm}$. in diameter, and are white to light yellow in color and show good cleavage. While sparingly scattered throughout the quartz they are more plentiful near the contact with the country rock, forming perhaps 10 per cent. of the mass. A little chlorite, occurring chiefly near the contact, white mica and an infinitesimal amount of pyrite make up the chief minor constituents. A few thin plates of ilmenite occur in the quartz near the wall rock. Under the microscope the feldspars show extreme alteration to kaolin and sericite, but multiple twinning can be detected on some of them, and this with the index of refraction identifies them as oligoclase-andesine. ${ }^{a}$. There is probably some

aThe indices of refraction as determined by Dr. E. S. Larsen, Jr., using the immersion method, were $\alpha=1.542 \pm 0.003$ and $\gamma=1.551 \pm 0.003$. 
orthoclase present but it could not be positively iclentified. The quartz in the slide shows some optical distortion and contains numerous gas- and liquid-filled cavities.

Pyrite nowhere seems to be an abundant constituent of the veins cutting the quartzite. It is usually present in small quantities, rarely amounting to more than 1 per cent., and wherever observed was fine-grained.

Gold occurs chiefly in the native state and can frequently be detected by panning. In a piece of the vein quartz obtained within 6 feet of the surface, close to the incline shaft at the Tellurium mine, gold is present in small flakes about $0.25 \mathrm{~mm}$. in diameter. At greater depth much of the gold is probably contained in pyrite.

A small amount of black splaalerite was identified in vein quartz from one of the stringer's in the quartzite, but this mineral seems to be very rare in the veins of the tellurium system.

'Tetradymite has been identified in ore at the Tellurium mine, being first analyzed by Coleman Fisher, Jr., and later by Dr. F. A. Gentl. ${ }^{b}$ The analysis given by the latter is as follows:

Analysis of tetradymite from the Tellurium mine, Virginia.

(Dr. F. A. Genth, analyst.)

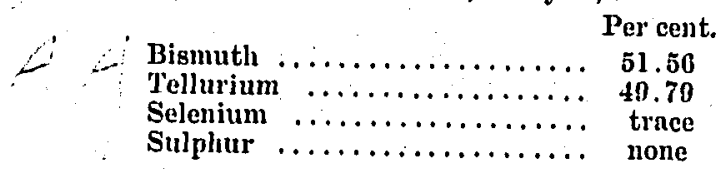

Genth states that in the specimen examined by him tetradymite occurs "in broad folia, sometimes 1 inch in diameter, implanted in a decomposed micaceous slate. . . . Before the blowpipe it fuses readily giving out a faint but distinct odor of selenium, leaving on charcoal white incrustations with a yellow center." Elsewhere he states that the tetradymite from the Tellurium mine is frequently interlaminated with gold, and experiments made by him proved that gold was easily precipitated from dilute solutions by tetradymite. ${ }^{\circ}$ His description of the gangue indicates that the specimen was probably obtained from the wall of the "Middle" or "Little" vein, rather than the veinlets in the quartzite bed, but these veins are all identical in their mineral composition and mode of formation.

aAmer. Jour, Sci., vol. vii, $2 d$ ser., p. 282.

bGentl, F. A., Contributions to Minernlogy, Amer. Jour. Sei, 1855, vol. vix, $2 d$ ser., pp. 15-10.

cGenth, F. A., Contributions to Mineralogy, Amer. Jour. Sci, 1858, vol, xxviii, $2 d$ ser., pp. $254-255$. 
Tellurium is mentioned by Credner as being present in the form of a conting together with gold, but the minernl seen by him was probably tetradymite. ${ }^{a}$

In order to show the distribution of the gold and the relative degree of mineralization, average samples of the veinlets and of the quartzite were carefully taken in the face of the drive sketched in fig. 12. The elements, gold, silver, iron, and sulphur, were determined in each of these samples and are tabulated below. The percentage of pyrite given in the table was computed from the amount of sulphur found, based on the assumption that all of the sulphur present is in the form of pyrite, which is essentially correct. The excess iron is present chiefly in the form of limonite, with a little chlorite, and possibly some ilmenite.

Partial analyses of ore from the Tellurium mine, Virginia.

(E. E. Burlingame \& Co., analysts.)

\begin{tabular}{|c|c|c|}
\hline & Vein quartz. & Qunrtzite. \\
\hline 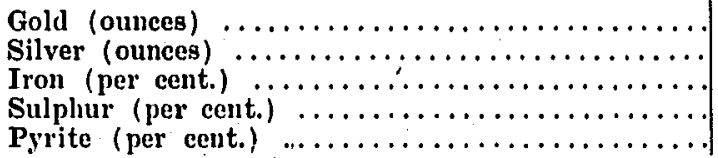 & $\begin{array}{r}0.12 \\
\text { trace } \\
1.00 \\
0.16 \\
0.30\end{array}$ & $\begin{array}{l}0.02 \\
3.00 \\
0.41 \\
0.77\end{array}$ \\
\hline
\end{tabular}

The quartzite which forms the greater portion of the "Big Sandstone" vein is fine-grained, even-granular, and light gray to almost white. when fresh, turning to light brownish-gray or pink on weathering. 'The rock has distinct schistosity parallel to the bedding, and when examined on fractures that cut across the schistosity it appears to consist entirely of quartz, while on surfaces paralleling the schistosity fine scales of sericite can always be distinguished and are usually abundant, giving the quartzite a high luster. A little fine-grained pyrite 'may' be recognized in places, but is never an important constituent. In a single instance, crystals of muscovite over $2 \mathrm{~cm}$. in diameter were found in quartzite adjacent to one of the veinlets.

In thin sections (Specs. 135, 147, and 189) under the microscope, the quartzite is composed essentially of interlocking quartz grains, less than $1 \mathrm{~mm}$. in maximum diameter and areraging about $0.25 \mathrm{~mm}$., which are partinlly oriented with their greater diameters roughly parallel to the schistosity. 'The quartz grains are so extensively recrystallized that they

$a$ Credner, H., Report of Explorations on the Gold Fields of Virginia and North Carolina, Amer. Jour. Mng., 1800, vol. vii, p. 9. 
furnish little evidence of their former size and shape. They usually show some optical distortion but little if any granulation, and contain occasional small fluid inclusions. Sericite is always present in small scattered flakes mostly parallel to the schistosity. The feldspars (orthoclase and acid plagioclase) are common in specimens of quartzite obtained near the veinlets, and seem to be rare or absent elsewhere in the quartzite. Where abundant the feldspars occur filling interstitial spaces between quartz grains, and in long, irregular, more or less broken lines parallel to the schistosity, indicating that they were formed later than the quartz, and suggesting that the feldspars may, have been introduced into the rock by the vein-forming solutions. The feldspars are partly kaolinized and show some alteration to sericite. The alteration of the feldspars together with their low index of refraction render easy their differentiation from quartz even where twinning is absent. The minerals chlorite, zircon, titanite, rutile, and ilmenite, partly altered to leucoxene, are present in small but varying quantities as unimportant accessory constituents.

The contacts between the stringers of vein quartz and the quartzite are well marked and easily recognized in the hand specimen because of difference in color and granularity, but under the microscope (Spec. 190) the contact is less sharply defined and is more of a gradation. The quartzite is completely recrystallized, so that the individual quartz grains interlock with those of the vein quartz, and the only difference between them is one of relative size. In the former the grains are seldom over $1 \mathrm{~mm}$. in diameter, while in the latter the quartz individuals average from 2 to $3 \mathrm{~mm}$. The quartz grains in both vein and quartzite show irregular, interpenetrating boundaries, strain shadows, and slight peripheral granulation. The vein quartz is practically free from impurities other than minute gaseous and liquid inclusions. The quartzite contains much feldspar, chiefly orthoclase with some acid plagioclase, which shows slight kaolinization and partial alteration to sericite. Sericite in small flakes is distributed throughout the quartzite, pyrite is present, usually in small cubes, and the minerals chlorite and zircon occur as minor constituents.

A specimen (188) found on an old dump at the Tellurium mine, contains a layer of rock 3.5 to 4 inches thick, which consists of fine-grained, impure quartzite, or schist interleaved with numerous narrow veinlets and lenticular eyes of quartz $1 \mathrm{~mm}$. to $1 \mathrm{~cm}$. in widt]. This layer was interbedded with the normal quartzite. Microscopic examination shows that the veinlets and lenses are composed chiefly of coarsely crystalline quartz, 
with minor amounts of feldspar-nlbite or albite-oligoclase and perliaps some orthoclase. The quartzite is very fine-grained and consists of quartz, feldspar, sericite, biotite, chlorite, pyrite, and a little titanite. The feldspars in the veinlets frequently have good crystal outline and range up to $1 \mathrm{~mm}$. or more in diameter. They usually occur near the border portions of the veinlets projecting into the fine-grained quartzite, and in places appear to be completely separated from the veinlets. These feldspars, while well formed, show rough outlines under the microscope, because along their boundaries the feldspars fill up the inequalities caused by irregularities in the adjoining quartz grains. Some of the feldspars show albite twinning but many are unstriated.

By decrease of quartz and increase of mica the quartzite passes into the overlying schists. In the hand specimen (141) the rock from the hanging wall of the "Big Sandstone" vein, where it was cut by a vertical shaft at the Scotia mine, is a light brown, fine-grained, schistose quartzite; and in thin section under the microscope it is even-granular, being composed of roughly rounded quartz grains, showing little or no optical distortion, and decreasing amounts of biotite, sericite, and chlorite. There is probably a little feldspar present, but it could not be positively identified. Some of the biotite shows partial alteration to chlorite. The minor accessory minerals are' a little pyrite, chiefly along bedding planes, small grains of ilmenite, largely altered to leucoxene, and occasional inclusions of zircon and rutile.

Another specimen (142) from the same locality is a fine-grained, light gray schist composed chiefly of quartz and sericite with scattered flakes of biotite and chlorite, and occasional garnets 1 to $3 \mathrm{~mm}$. in diameter. Other minerals present are pyrite, zircon, titanite, and leucoxenc.

Between the quartzite and the middle vein the rock is mostly a finegrained, light bluish-gray schist composed essentially of quartz, sericite, and biotite. In places it contains impure garnets 1 to $2 \mathrm{~mm}$. in diameter, and sometimes there is much fine-grained pyrite present.

The thin strip of rock underlying the quartzite (see fig. 12) in many ways resembles the garnetiferous bed that occurs on the east side of the quartzite near New Canton (see pp. 10\%-108), and elsewhere, except that no sillimanite or cyanite could be identified in the rock at the Tellurium mine. In color the rock varies from dark gray where freshest to dark brown or greenish-brown. It consists chiefly of numerous reddish-brown garnets ranging up to $5 \mathrm{~mm}$. in diameter, imbedded in a schistose ground-mass of biotite usually altered to chlorite. In thin sections (Specs, 186-A and -B)- 
under the microscope much feldspar-both acid plagioclase and orthoclase - can be distinguished, and the minerals, quartz, ilmenite, mostly altered to leucoxene, pyrite, and sericite, are also present. The garnets occur in well-formed dodecnliedrons containing inclusions of ilmenite and lencoxene. The biotite is light brown in color and in some specimens is largely altered to chlorite. The feldspars are extensively kaolinized, contain inclusions of biotite and chlorite, and in places show albite twinning.

This strip of foot-wall rock was encountered at the Bowles and Scotia mines as well as at the Tellurium. Pieces of rein quartz were found on the dump at the Bowles mine with some of the foot-wall adhering, which contained garnets orer $1 \mathrm{~cm}$. in diameter, partly imbedded in the vein quartz and partly in the wall rock.

At the Scotia mine dark green hornblende is found in places where the vein quartz, containing feldspar, occurs in contact with the rock underlying the quartzite. Occasionally small veinlets extend from the quartz vein out into the country rock and these carry much feldspar, white to yellow in color. 'The hornblende is present in the wall rock close to the rein, sometimes being the chief constituent, and does not seem to extend farther than 3 or 4 inches from the contact with the vein. This hornblendic rock grades into the normal biotite-chlorite-garnet schist described above. Examined microscopically (Spec. 143-B) the hornblende is light green to colorless, and shows alteration to chlorite and epidote. Quartz occurs in irregular grains showing optical distortion. Much titanite is present in clear, light pink to colorless grains, well-formed crystals of rutile occur as inclusions in the quartz, and ilmenite is also a minor constituent. Both rutile and ilmenite show partial alteration to leucoxene.

A specimen (194) of the rock underlying the narrow strip described above was obtained in the face of the northeast drive from the Tellurium incline shaft ( $E$ in fig. 12). It is a light brown schist similar in mineral composition to the overlying rock, except that it is finer grained and more siliceous. The minerals present are quartz, biotite and chlorite, garnet, feldspar, sericite, pyrite, leucoxene derived from ilmenite, and titanite, the order given being that of relative abundance. The quartz grains are small and show little optical distortion. Biotite is present in brown flakes containing occasional inclusions of quartz, and is extensively altered to chlorite. The garnets are light pink in color and show slight alteration to chlorite along fractures. They contain numerous -inclusions of quartz, pyrite, and ilmenite partly altered to leucoxene. 'The feldspars-orthoclase and acid plagioclase-nre extensively knolinized. 
'The "Middle" vein is conformable in strike and dip with the enclosing schists, and therefore parallel to the quartzite bed. It is extremely variable in width, consisting of a series of small lenses which range up to 3 feet or more in thickness; and these lenses are all strung out along the same line, being usually comnected by a narrow stringer. (See fig. 13.) In this respect the "Middle" vein is imnrkedly different from the veinlets in the

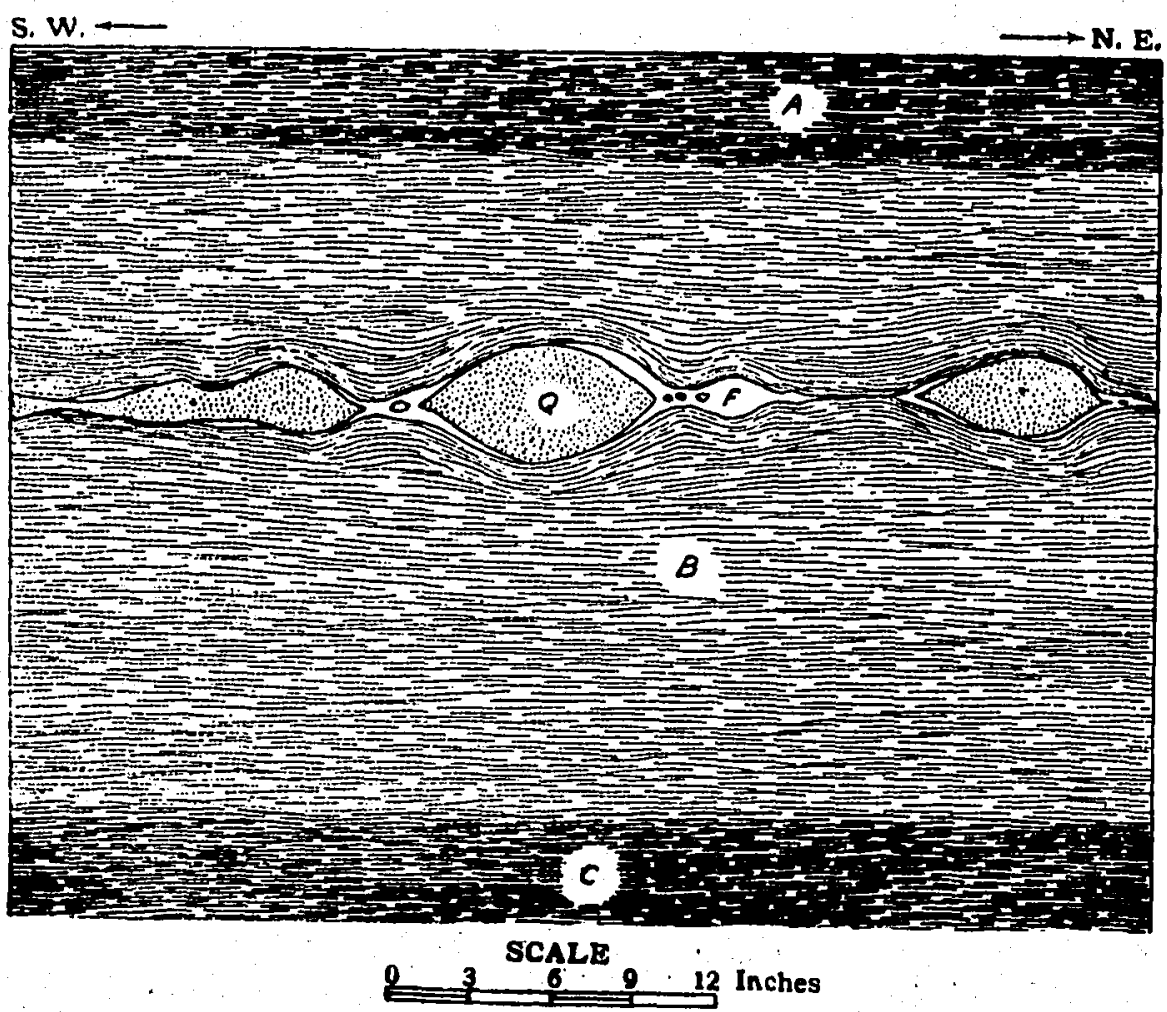

Fig. 13.-Dingrammatic sketel sliowing symmetrical lenses of the middle vein at the Tellurium Mine. $Q$, quart\%; $F$, feldspar; $A$, hanging wall schist; $C$, footwall schist; $B$, bed of light-colored schist.

quartzite, for the latter are seldom lenticular in shape, frequently cut across the bedding of the enclosing rock, and are variable in their strike and dip.

The lenses forming the "Middle" vein are separated in places by a distance of several feet, and the veinlets connecting them may pinch to almost nothing so that only a faint line remains, but it can usually be distinguished without difficulty. In the partly decomposed schists near the 
surface this line is marked by the dark stain of oxides of iron, probably from the alteration of pyrite; and when the soft material is broken away a little coarse grit, due to the presence of quartz, can be detected on the line. Feldspar is an important constituent of this vein, but in the openings that are now accessible it is completely altered to kaolin. The knolin

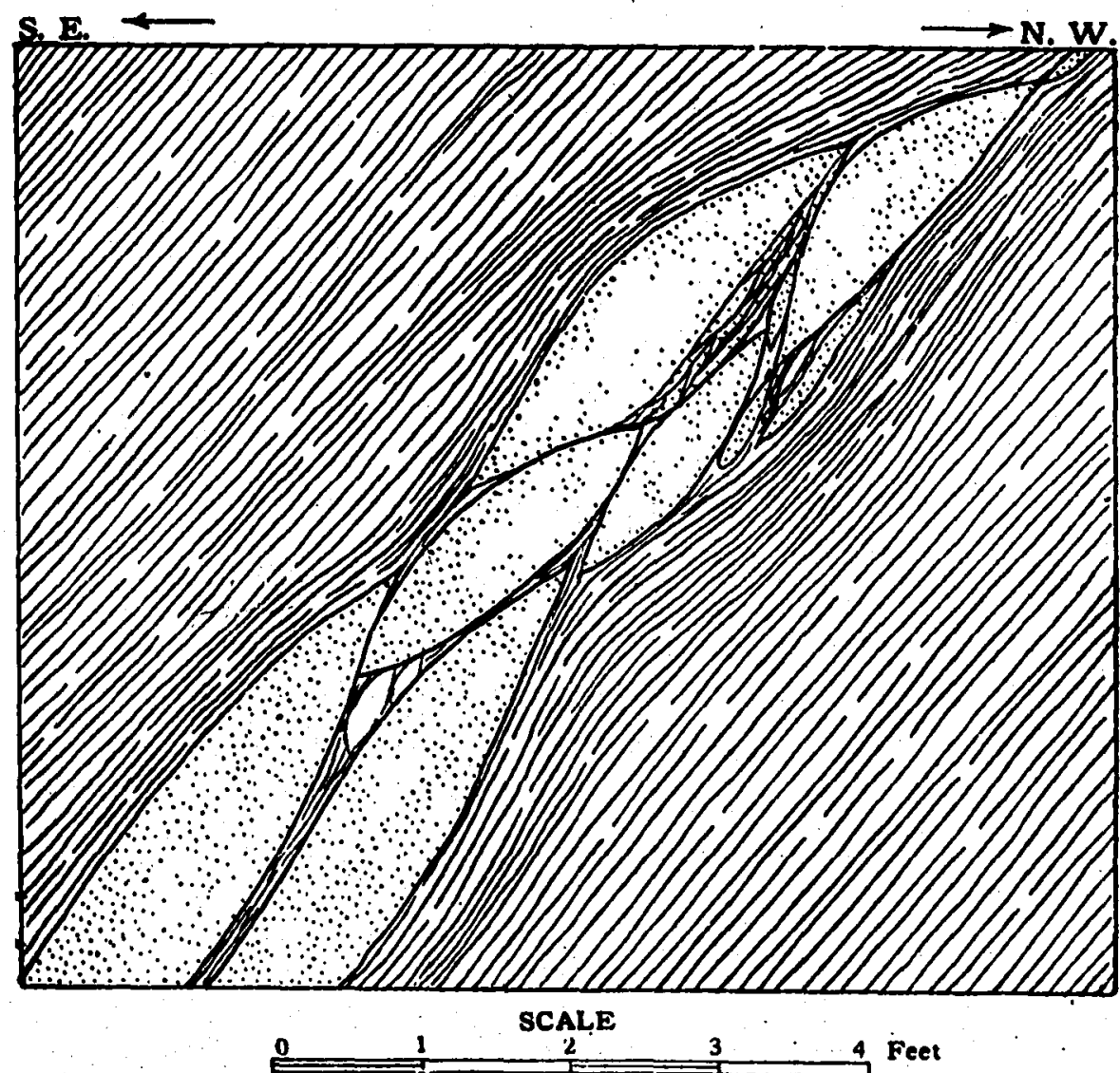

Fig. 14.-Vertical section of middle vein at the Tellurium Mine, showing large lens composed of smaller lenses.

occurs in small angular shapes distributed throughout the quartz, but is mostly found along the border portion of the lenses, and especially at points where they narrow and pinch out. (See fig. 13.) Some of the smaller lenses 2 or 3 inches in length are composed entirely of kaolin. In plnces the larger lenses are made up of a number of smaller ones as shown 
in fig. 14, and where this occurs there is occasionally a little schist included between the component lenses. At one point the vein is cut by a vertical fault which displaces the vein about 2 feet. (See fig. 15.)

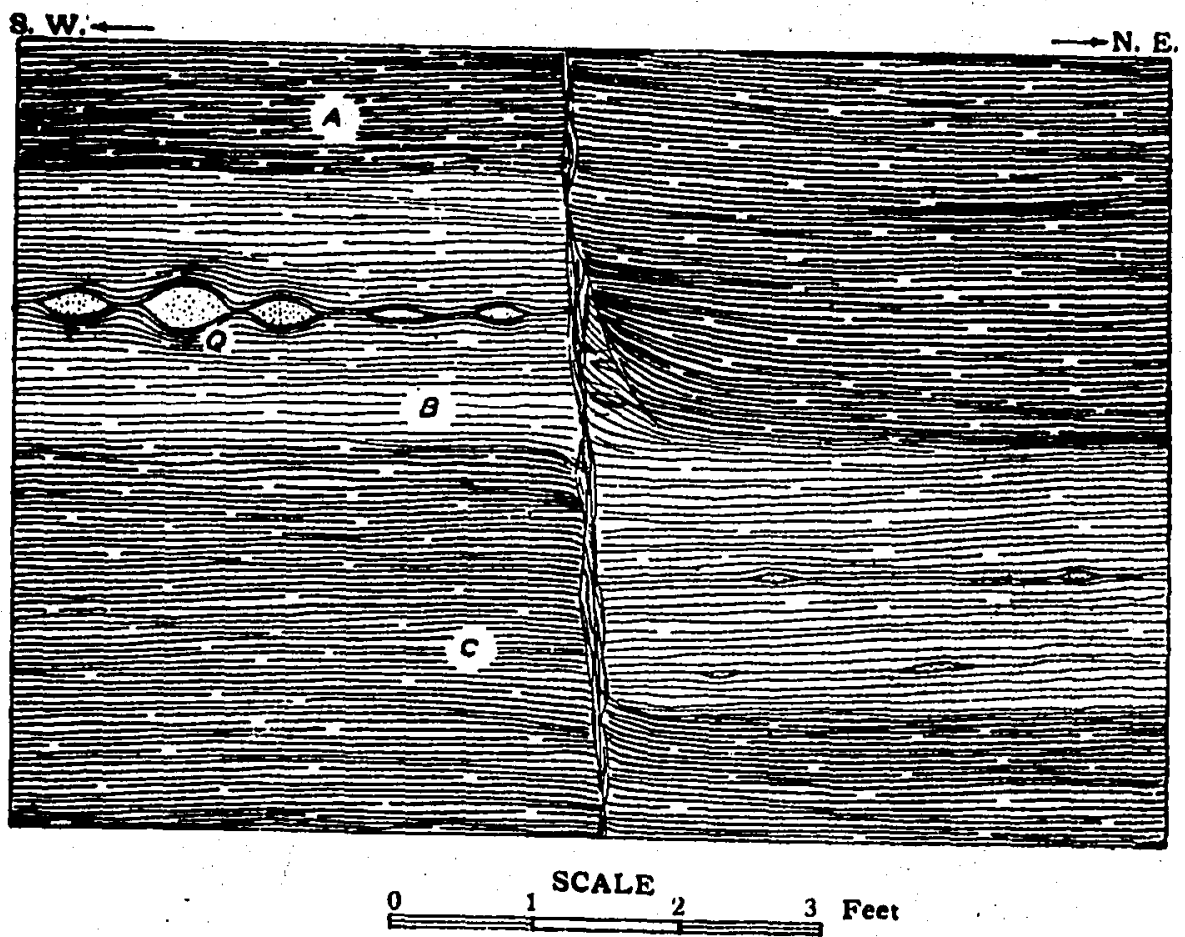

Fig. 15.-Vertical section showing symmetrical lenses of the middle vein of the Tellurium Mine, and a small fault. $Q$, quartz-feldspar lenses; $A$, hanging wall schist; $C$, foot-wall schist; $B$, bed of light-colored schist.

The formation of the peculiar lenses which constitute the "Middle" vein is discussed in detail in the chapter on genesis, pages 224-230, and therefore nothing further concerning them will be said here.

'The "Middle" vein is similar in mineral composition to the veinlets that cut the quartzite bed and constitute the chief gold-bearing portion of the "Big Sandstone" vein, but it probably contains a larger percentage of feldspar. According to report, the "Middle" vein is much richer in gold than the "Big Sandstone," and this is unquestionably true if the whole bed of quartzite is included with the veinlets, but it is questionable whether the average value of the gold-bearing veinlets that occur in the quartzite is greatly below that of the "Middle" vein. An average sample, 
taken across a lens in the vein $21 / 2$ feet wide, yielded $\$ 2.07$ gold per ton, but it should be understood that this does not represent the average value of the vein. The best ore seems to occur in pockets or shoots, and much of the ore that has been stoped out unquestionably carried high values in gold. An ore pile on the surface showed much gold when tested by panning, and specks of visible gold are not infrequent in fragments of the ore. The wall rocks apparently are not mineralized to any appreciable extent.

The "Middle" vein is enclosed in a series of fine-grained, knotted schists, containing pseudophenocrysts of garnet. 'The folia of the schists in the immediate vicinity of the vein are wrapped around the lenses, conforming to every curvature of the ore-body, but in passing away from the vein the flexures gradually disappear, and at a short distance the folia are straight and undisturbed. (See fig. 13.)

The vein appears to follow a bed of light-colored schist 2 to $21 / 2$ feet thick interbedded with darker schists. Where exposed these rocks are so badly altered that it is not possible to obtain material sufficiently fresh for microscopic examination. The light-colored schist is composed essentially of quartz and sericite, with small, scattered brown spots due to the alteration of garnet. Along fractures and joint planes it is stained with iron, but elsewhere it is almost white in color. The overlying schist is light bluish-gray, and contains decomposed garnets 3 or $4 \mathrm{~mm}$. in diameter, embedded in a fine-grained ground-mass. The folia of the schist are wrinkled or folded to form lenticular eyes around the garnets. The underlying schist is similar to the one last described excepting that the garnets are less numerous and smaller in size.

Pieces of unaltered garnetiferous schist, similar to the decomposed schist described above, were found on the dump of the 136-foot vertical shaft sunk in the hanging wall of the Tellurium veins. In the hand specimen (178) it is a thinly foliated, fine-grained, bluish-gray rock with high luster on surfaces parallel to the schistosity, and is spotted with numerous garnets in well-formed dodecahedrons 1 to $2 \mathrm{~mm}$. in diameter. With the aid of a pocket lens, quartz, sericite, and biotite may be identified as the chief minerals of the ground-mass. Under the microscope the garnets are seen to be full of small inclusions consisting of grains of quartz, ilmenite partly altered to lencoxene, and a black opaque mineral in dust-like particles, possibly ilmenite: The ground-mass is composed of small irregular grains of quartz, with flakes of sericite, biotite, and chlorite, all of which are crowded with the black dust-like inclusions. Leucoxene is plentiful in grains which frequently contain muclei of unaltered ilmenite." 
Occasionally the garnets are partly or wholly surrounded by a zone from which most of the minerals other than quartz have disappeared, probably entering into the composition of the garnet; and the quartz has recrystallized into small, elongated grains, with their longer diameters oriented in approximate alignment with radii extending from the garnet. (See Pl. V, fig. 2.)

Pieces of rock, evidently igneous in origin, were found on the dump of an old shaft, which was sunk in developing the "Big Snndstone" vein at the Tellurium mine, but is now completely caved. In the absence of chemical analyses or knowledge of the structural relations, it is impossible to definitely classify this rock, but it is not improbable that it is genetically related to the granite on the northwest. In the hand specimen (185) the rock is light gray in color, fine-grained, and very schistose. Roughly formed, reddish-brown garnets and small flakes of biotite can be distinguished in a white ground-mass composed of quartz and feldspar. Examined in thin section, feldspar phenocrysts are seen, ranging up to $2 \mathrm{~mm}$. in length, which, with flakes of biotite about $0.5 \mathrm{~mm}$. in length and irregular garnets, occur in a fine-grained ground-mass composed of quartz, feldspar, biotite, a little sericite, and inclusions of lencosene, zircon, titanite, and rutile needles. The feldspars are acid plagioclase (albiteoligoclase (?) $A$ ' and orthoclase, the larger individuals have very irregular outlines, and they contain numerous fluid-filled cavities and small. inclusions of zircon and the titanium minerals.

A different appearing igneous rock found on the same dump is much more schistose than the one previously described, and may represent an interbedded acid extrusive, or a dike rock older in age than the granite and its differentiates. It contains numerous garnets 1 to $2 \mathrm{~mm}$. in diameter and flakes of biotite, embedded in a light brown, schistose groundmass, composed essentially of feldspars, more or less knolinized. Examined under the microscope the garnets are very ragged in outline and contain numerous inclusions of quartz. Feldspars, chiefly soda plagioclase, are dominant in the thin section, though a little orthoclase is present. Some of the larger feldspars are bent and broken, the fractures being filled by minerals of later crystallization. The minor constituents are quartz, pyrite, and leucoxene.

'The hypothesis that these rocks are genetically connected with the granite is strengthened by the presence on one of the dumps of hornblendic schists, such as are found in the immediate vicinity of granite throughout the area. A hand specimen (179) of hornblende schist found 
on the dump of the 136-foot shaft at the Tellurium mine, consists of coarse-bladed crystals of dark green hornblende ranging up to 1.5 or $2 \mathrm{~cm}$. in length, and white, fine-grained quartz and feldspar. Small grains of pyrrhotite, pyrite, and magnetite are plentifully distributed throughout the rock. Under the microscope the hornblende is ragged in outline, and micropoikilitic in texture from numerous inclusions of quartz, magnetite, and pyrite. The cleavage is well developed and they are usually dark green in color, though some are nearly colorless. The quartz occurs in small rounded grains and is difficult to distinguish from the unstriated feldspar. The latter is acid plagioclase; probably no orthoclase is present in the rock. Magnetite is plentiful in small idiomorphic grains. Calcite and fibrous serpentine occur as vein-filling in a microscopic fracture.

Another variety found on the same dump is much finer grained. It is a greenish-gray schistose rock (Spec. 180) in which quartz, hornblende, magnetite, pyrite, and a little sericite can be distinguished with the aid of a pocket lens. In - thin section the hornblende occurs, partly in dark green to colorless crystals with well-developed cleavage and strong absorption in the darker varieties, and partly in nearly colorless needles often clustered together in radiating groups. Quartz and an unstriated feldspar, probably acid plagioclase, are present in rounded grains showing little optical distortion.' Much magnetite, in idiomorphic crystals ranging up to $1 \mathrm{~mm}$. in aiameter, is plentifully distributed throughout the rock.

'The lenticular bed of ferruginous quartzite, known as the "Hodges" vein, which has been developed to some extent at the Scotia mine, is situated about 600 yards southeast of the course of the "Big Sandstone" vein. 'The few exposures in the vicinity indicate that the quartzite is interbedded with quartz-sericite schists. A small prospect pit, located about 300 yards northeast of the openings on the "Hodges" vein and approximately in line of strike, exposes a thinly foliated schist, which in the hand specimen (211) appears to be composed entirely of sericite and quartz. It is white in color when not stained with limonite, and contains occasional eyes of light blue opalescent quartz about $0.5 \mathrm{~cm}$. in lengtli. The strike of the schistosity is $\mathrm{N} .60^{\circ} \mathrm{E}$. and the dip $30^{\circ}$ toward the southeast.

The shape of the quartzite bed, where it is exposed by short drives from the bottom of the incline shaft, is shown in fig. 16. The maximum width is over 6 feet, and from this the bed tapers down to a fraction of an inch at either end. The average dip is southeast $35^{\circ}$ and the strike about N. $40^{\circ} \mathrm{E}$. Although the quartzite apparently pinches out at either end of the lens, much float rock identical in appearance and composition occurs on the 
surface about three-quarters of a mile northeast, and at several other points in the same general alignment.

Megascopically the quartzite is fine-grained, even-granular, and somewhat variegated in color because of local concentration of the various oxides of iron. In places the rock is white to light gray in color, consisting chiefly of quartz, with only a small amount of iron in the form of specular hematite and octahedral crystals of magnetite. Elsewhere the rock is dark brown

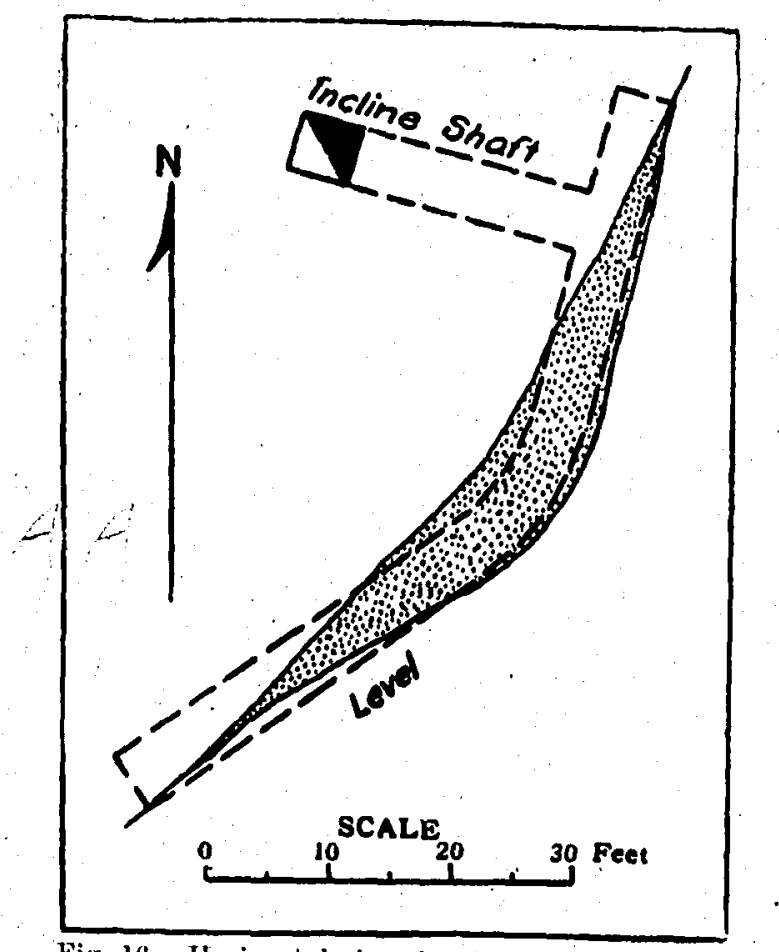

Fig. 10.-Horizontal plan showing lenticular shape of ferruginous quartzite bed exposed in under. ground openings at the Scotia mine.

to black in color and contains a larger percentage of the iron minerals, which are usually extensively altered to limonite. The two colors are irregularly intermixed, blotches of white being enclosed in areas that are dark brown in color and vice versa. Near the center of many of the dark areas, much fine-grained magnetite is found, and along the contact between the light and dark areas there is often a narrow, red-colored band, probably due to iron stain on the quartz grains. 
In thin section (Spec. 153) under the microscope the rock is essentially the same as the non-gold-bearing ferruginous, quartzites which occur at a large number of localities in the area, described in detail on pages 19-22. The quartz grains are roughly rounded, nearly uniform in size, averaging about $0.25 \mathrm{~mm}$. in diameter, and show no optical distortion. This close interlocking texture is due to recrystallization, which probably resulted in some enlargement of the individual grains. Small idiomorphic inclusions of martite (magnetite altered to hematite) are present in the quartz; and the larger masses of iron ore, occurring between the quartz grains, show considerable alteration to limonite, which in many places stains the boundaries of the other minerals. Zircon and a fẹ small rutile needles are unimportant minor constituents.

The quartzite is cut by occasional irregular stringers of quartz, which range up to 10 inches or more in width, and very rarely contain rug-like cavities lined with quartz crystals. The stringers occur mostly on the foot-wall side of the quartzite. They carry a little pyrite largely altered to limonite, and probably a small amount of feldspar, though the latter mineral was. not positively identified. The presence of gold is casily detected by panning, and sometimes small specks of free gold can be identified in hand specimens, usually in association with limonite derived from pyrite.

Tests made by panning indicate that the quartzite away from the goldbearing veinlets carries little if any gold. Sometimes a small amount of pyrite may be found in the quartzite near the veinlets, but most of it occur's as a coating along fractures and is evidently secondary in origin.

\section{The Scotia Mine.}

Location.-The Scotia property is situated about half a mile north of Caledonia and 7 miles northeast of Columbia. 'It adjoins the Tellurium mine and is crossed by the sopthwestern extension of the same vein system.

History and description.-This property was formerly known as the Perkins mine and under that name was prospected in the early days of gold mining in Virginia. According to Credner the ore used to pay the working expenses. After 1849 very little work was done until the Scotia Mining Co. began prospecting in 1910. An account of the development work is given below and a detailed description of the veins and country rock will be found on pages $15 \%$ to 172 .

A drain tunnel was driven 105 feet in a direction $S .11^{\circ}$ E., cutting the "Big Sandstone" vein near the portal and also two small stringers that were called the "Middle" and "Tittle" veins. The country rock is much decomposed, but where fresh enough for identification consisted of 
knotted garnetiferous schists similar to those at the Tellurium mine. A 67-foot vertical shaft sunk in the hanging wall, cut the "Big Sandstone" vein near the bottom. It was partly filled with water when the property was examined by the writer, but much fresh rock was exposed on the dump and this is described, together with the veins of the Tellurium system, on pages 157 to 164 . The "Big Sandstone" vein was exposed in a pit sunk on the outcrop 100 feet northwest of the vertical shaft. Here the quartzite bed had a strike of N. $50^{\circ}$ E., a dip of $35^{\circ}$ southeast, and varied from 8 inches to 3 feet in width, averaging about 18 inches. It is cut by veinlets of massive white quartz carrying considerable kaolinized feldspar. The same vein has been prospected on this property by several other surface cuts.

An old incline shaft near the western boundary of the property was reopened by the Scotin Mining Co. It was sunk on a vein called the "Middle" vein, which has a maximum width of 2 feet about 12 feet from the surface and pinches to an inch near the bottom, 25 or 30 feet from the surface. The strike is approximately N. $60^{\circ} \mathrm{E}$. and the $\operatorname{dip} 35^{\circ}$ southeast. The enclosing rock, consisting of knotted, garnetiferous schist, is conformable in strike and dip, and is cut by vertical joint planes, spaced 12 to 18 inches apart, which have a strike of $N .44^{\circ} \mathrm{W}$. It is improbable that this vein is continuous; with either of the stringers in the drain tunnel or with the "Middle" vein at the Tellurium. Small stringers like these are not as a rule continuous for great distances but pinch out and are replaced by others a little farther along the line of strike.

Near the southwestern corner of the Scotia property there is a bed of ferruginous quartzite cut by small gold-bearing stringers, which is known as the Hodges vein. It has been developed by several surface cuts and an incline shaft on the vein, 43 feet deep, from which short drives were run in northeast and southwest directions. A detailed description of the ore and country rock is given on pages $170-172$.

\section{Gold Prospects Southwest of the Scotia Mine.}

Passing southwest along the strike of the Tellurium vein system, old prospect holes are found at short intervals as far as Big Byrd Creek, but, while gold has been found at a number of these places, very little development work has been done.

On the Jennings tract adjoining the Scotia there are several old shafts and surface pits located along the strike of the Tellurium veins, but these are now caved and do not seem to have reached a depth of more.than 40 . 
feet. Knotted garnetiferous schist, having a strike of N. $60^{\circ}$ E. and dip of $30^{\circ}$ southeast, is exposed in one of the openings, and quartzite similar to that at the Tellurium mine is present on one of the shaft dumps.

By means of surface cuts, the quartzite bed has been traced across the Mosby, Fountain, and Cocke properties, and placer gravels have been worked along the branches that run through them and enter Big Byrd Creek. It is said that the "Big Sandstone" vein was prospected on the Fountain property in 1837 by Geo. Fisher, and another vein, known as the Marks vein, was also opened and worked to some extent. The ore was crushed in a small 3-stamp mill on Horsepen Creek and yielded $\$ 75$ per day. ${ }^{a}$

Some mining has also been done on the old Bartlett place in this vicinity. Gold was discovered in the Bartlett Branch, which enters Big Byrd Creek from the east a short distance above Bowles' bridge, and the placer gravels are said to have been worked by the Fishers. Later the Bartlett vein was discovered and prospected and a little mining done. The ore from this vein was carried to Bowles' Mill on Big Byrd Creek and crushed in a small wooden stamp mill operated by the same power that ran the grist mill.

Recently some prospecting has been done on a part of the old Payne farm, now known as Cassell's mine. The place is situated on the county road about 2 miles northwest of Caledonia and 3 miles southwest of Kent's Store. A small amount of ore has been mined and milled but all the work has been of a superficial nature. Several shafts and cross-cuts, all above water level, have been sunk in decomposed rock, and the only veins exposed when the openings were examined by the writer, consisted of a few quartz stringers less than an inch in width. Part of the workings are in a decomposed dike-like rock about 20 feet wide which appears to be pegmatite. It is not well exposed but has a probable strike of N. $6^{\circ} \mathrm{E}$.

Close to the other openings a pit has been sunk on a highly ferruginous quartzite bed 8 feet or more in thickness. The quartzite is dark brown with occasional light-colored spots, and is cut by closely spaced joints. It is composed of fine-grained quartz, hematite, and a little magnetite, and the light spots seem to be due to recrystallization of silica. In places along cracks or cleavage planes a crust of magnetite has been formed consisting of crystals 2 to $3 \mathrm{~mm}$. in diameter. The quartzite is cut by quartz veinlets 1 to 2 inches in width which frequently contain plates of micaceous

aCredner, H., Report of Explorations on the Gold Fields of Virginia and North Carolina, Amer. Jour. Mng., 1869, vol, vii, pp. 42.43. 
hematite. Examined under the microscope (Spec. 209) it seems to have undergone greater recrystallization than the other ferruginous qunrtzites of the area. The quartz grains lack uniformity in size and are irregular in outline; they usually show optical distortion and contain comparatively few inclusions of the iron ores, while the larger masses of hematite contain small inclusions of quartz. The iron ores are partly altered to limonite, and the latter in places stains the contacts between the quartz grains.

\section{The Bowles Mine.}

Location.-The Bowles property is situated 11/2 miles southenst of Tabscott and about 8 miles northeast of Columbin. It lies east and northeast of the Tellurium mine, and embraces a large area of land in both Goochland and Fluvanna counties.

History and general description.- The placer gravels along the two branches that run through the property were extensively worked for gold prior to the Civil War. After the veins of the Tellurium system had been developed on the property of that name, they were traced across on to the Bowles tract and prospected at several points. Prospecting has been renewed at several different periods and considerable development work carried out. A'shaft started on the outcrop of the "Big Sandstone" vein was sunk about 100 feet on the dip of the vein, and 50 feet from the collar a cross-cut was driven southeast to connect with a vertical shaft at a point about 4.0 feet below the surface. The vertical shaft was sunk to a depth of 72 feet, and after striking the "Little" vein was continued for 45 feet. along the dip of the vein. When visited by the writer in 1910 the shafts were partly filled with water and all the workings inaccessible. The data given above were furnished by Mr. Ferris, who was in charge of the property at the time. The character of the veins and the structural relations of the wall rock, which are the same as at the Tellurium mine, are described in detail on pages $15 \%$ to 172.

The Gold Hill vein system crosses the northwestern end of the Bowles property, and several of the veins belonging to it were prospected at an early date. A number of shafts and other openings have been made, but practically all of them are now caved. The most extensive workings are located on the Gold Hill vein, and the Shaw or Back Field vein. Ores from the former vein were hauled to the Tellurium mill for treatment when mining was in progress about 25 years ago. A little work has been carried on recently by Mr. Ferris, who mined a few tons of high-grade ore from a small opening on the Back Field vein and crushed it in the Tellurium mill. The veins belonging to the Gold Hill system are described in detail below. 


\section{The Gold Hill Vein System.}

Introduction.-The Gold Hill vein system is situated about 2 miles southenst of Kent's Store and 2 miles west of Tabscott, and extends for a mile or more in a general northeast-southwest direction. It consists of a series of small veins, which show a greater variation in strike and dip than is found elsewhere in the district, but none of them seems to be very persistent. The veins have been developed to some extent at several places on the Bowles, Shaw, and McGloam properties, but all the work has been rather superficial in its nature. These veins differ from other veins of the district in several important characteristics besides their lack of uniformity in strike and dip. They are located in an area of fine-grained granite, and are the only known gold-bearing veins within this district that occur in granite. The veins are characterized by the presence of coarsely crystalline pyrite, which frequently occurs in large cubical shapes $1 \mathrm{~cm}$. or more in diameter.

Country rock.-. There are few exposures of the country rock except where openings have been made in prospecting the gold veins. The dominant rock is a fine-grained granite, and this contains areas of hornblende and chlorite schists, which are more noticeable near the border portions. Because of the extensive decomposition of the rocks in this section it is not possible to accurately map the boundaries of this granite area, but it has a width of more than one mile, and extends for an unknown distance in a northeasterly direction, probably connecting with the main granite batholith that lies to the east.

The granite where freshest is a light gray, fine-grained rock, with scarcely any schistosity. The minerals visible to the naked eye are quartz and feldspar, with numerous small flakes of dark green chlorite, a little sericite, small cubes of pyrite, and occasional grains of magnetite. In thin sections it varies from granitic to granophyric in texture, intergrowths of quartz and the feldspars being common, and in places very abundant, while small phenocrysts of feldspar are present in some of the rock. The feldspars are acid plagioclase and orthoclase, with sometimes a little microcline. The white mica is apparently all secondary, and frequently shows intergrowths with quartz. The chlorite is probably derived from biotite. a mineral which is present in small quantities only. Calcite is plentiful in some slides and is probably derived chiefly from the feldspars. The minor constituents occurring in the rock are zircon, leucoxene, apatite, and rutile needles, while fluid inclusions are numerous in some of the quartz grains. (Specs. 82, 83, 158, 161, and 166.) 
The hornblende schist is exposed at several points in narrow bands interleaved with granite, and also in areas at least several hundred feet across. Theșe schists are similar to the corresponding schists in the larger granite area, and are doubtless the same in origin. The rock is dark green in color and varies from medium conrse- to fine-grained. Hornblende, often largely replaced by chlorite, quartz, and feldspars, are the chief constituents ; pyrite and magnetite can usually be recognized megascopically; and in some of the rock small grains of rutile and ilmenite can be identified. Under the microscope the larger hornblendes are ragged in outline and micropoikilitic from numerous inclusions of quartz and magnetite. The feldspars (acid plagioclase) are clear, unstriated, and difficult to distinguish from quartz except by their lower index of refraction. Occasional grains of titanite, inclusions of zircon, and small rutile needles constitute the minor accessories. (Specs. 80, 81, 159, 160, 165, and 167.)

Granite is the principal rock composing the dumps from shafts sunk on reins belonging to this system, and the hornblende schist is present in smaller amounts or entirely absent.

The McGloam mine.-The McGloam mine is situated half a mile north of the Tellurium and joins the Bowles property which lies to the east. There are 2 shafts on the property 300 yards apart, one vertical and the other on a flat'jncline, but both are now filled with water. A vein, 1 to 2 feet wide, is exposed in the mouth of the incline shaft. It has a strike of N. $70^{\circ}$ E. and dips soutleast at an angle of $30^{\circ}$. 'The fine-grained granite, a little hornblende schist, and considerable vein quartz are present on the dump.

The vein quartz contains much coarsely crystalline pyrite, and in some pieces this has been partly or wholly removed, learing cavities in the quartz which frequently show no staining from oxides of iron. A little free gold can sometimes be detected by panning. In places the vein quartz is interleaved with narrow bands of fine-grained granite which in the hand specimen resembles quartzite, for it contains practically no ferromagnesian minerals. A thin section (162) examined under the microscope, contains a veinlet of quartz $3 \mathrm{~mm}$. wide enclosed by granite. The veinlet has sharply defined boundaries and is composed of quartz, containing numerous fluid inclusions, a very little feldspar, and some sericite. The enclosing rock is granitic to granophyric in texture, and consists of irregular rounded grains of quartz and feldspar, with a fine intergrowth of feldspar and quartz filling the interstitial spaces. The feldspar is chiefly acid plagioclase, usually slowing albite twinning, but orthoclase is also present and 
occasionally forms Carlsbad twins. A few flakes of sericite, small, scattered grains of magnetite, inclusions of zircon, and minute ruilile needles make up the minor accessory minernls. A piece of granite found on the dump was cut by a stringer of quartz 1 inch in width, which contained small vugs lined with quartz crystnls.

Fine-grained granite and vein quartz were found on the dump of the vertical shaft, but no hornblende schist. The vein quartz (Spec. 162) contains coarsely crystalline pyrite, and angular inclusions and irregular streaks of the country rock. The inclusions, which are often large, give to the weathered rock the appearance of pegmatite. They are composed essentially of fine-grained feldspar and quartz which under the microscope are seen to be closely intergrown. The vein quartz shows little optical distortion and contains numerous fluid inclusions, usually arranged in long, broken lines which may pass without interruption from one individual to another.

The Shaw mine.-The Shaw property is situated $11 / 2$ miles northeast of the Tellurium mine, and on the east side of the northern portion of the Bowles tract. There are several shallow shafts located close to the small branch which passes through the property, but they are now partly caved and filled with water. They are said to have been sunk on the Shaw vein which has a strike of N. $80^{\circ} \mathrm{E}$. Granite and hornblende schist were found on the dump, and the former rock outcrops at several places.in the vicinity.

The Bowles mine.-The Bowles property is described on page 175, and therefore only the veins belonging to the Gold Hill system will be mentioned here.

Near the northern end of this property there are scveral pits and small shafts, which are said to have been sunk on the "Shaw" vein, or "Back Field" vein as it is sometimes called. Only one of the openings was accessible when the property was examined by the writer, and this was not over 30 feet in depth. The vein where it is exposed varies from 1 foot down to a fraction of an inch, but Mr. Ferris, who was in charge of the property, states that in places it attains a width of 4 feet. The strike is about $\mathrm{N} .60^{\circ} \mathrm{E}$. and the dip $30^{\circ}$ southeast, so it is hardly probable that this vein is the extension of the one opened on the Shaw property. In places the vein carries considerable pyrite, partly altered to limonite, and at such points it is said to be rich in gold. A specimen examined by the writer contained grains of gold $2 \mathrm{~mm}$. in dinmeter. Some of the vein quartz found on the dump contains cavities, evidently left by the oxida- 
tion and removal of pyrite, for some of them are partly filled with limonite; and attached to the walls of these cavities are numerous octahedra of magnetite $1 \mathrm{~mm}$. and less in diameter. The wall rock where exposed consists of kaolin and quartz stained with a little iron, and is undoubtedly residual decay from the fine-grained granite found elsewhere in the vicinity.

About 500 yards south, a vein 1 foot in width is exposed by a small pit. It has a strike of $N .22^{\circ} \mathrm{E}$. and is nearly vertical. The quartz contains coarse cubical crystals of pyrite similar to those found in the other goldbearing veins in this granite area. Between this point and the McGloam vein numerous openings have been made, but they are not in perfect alignment and the veins which were prospected seem to have different courses. The greatest amount of development work was done at a point where the Gold Hill vein, running northeast-southwest, is said to be intersected by the "Cross" vein. There are several shafts and pits now caved along the course of the latter vein, which has a strike of $\mathrm{N}$. $30^{\circ} \mathrm{W}$., and is said to dip southwest at an angle of about $35^{\circ}$. This work was done many years ago and little is now known concerning these veins. A piece of quartz containing small prisms of black tourmaline was picked up near the outcrop of the "Cross" vein.

\section{The Page Mine.}

The Page mine is located in Fluvanna County on Long Island Creek a mile west of Wilmington. The reins on this property were first mined in 1856 and an 8-stamp mill was built to crush the ores. ${ }^{a}$ According to Credner the ore was derived from 2 quartz veins, carrying fine-grained galena and gold, which were opened by several tunnels and shafts. ${ }^{b}$ The mill was in ruins at the time of his visit in 1865 . It is reported that prospecting was renewed about 1895 , but no mining seems to have been done.

When the property was visited by the writer in 1911 the only accessible opening was a tunnel about 20 feet long which ran under the hill on the west side of the creek. The country rock exposed in the tunnel is a partly decomposed slate but no vein could be seen. Most of the work was done on the east side of the creek where there is an old caved tunnel, and on the hill above it several pits and open cuts. No rock was exposed on this side of the creek, but on the tunnel dump large pieces of vein quartz were found and some of them contained inclusions of chloritic slate, and narrow, irregular veinlets of calcite.

aNitze, H. B. C., and Wilkins, H. A. J., Gold Mining in North Carolina and Adjacent Appalachjan Regions, Bull. 10, N. C. Geol. Surver, 1897 . 75 .

bCredner, H., Report of Explorations on the Gold Fields of Virginia and North Carolina, Anier. Jour. Mng., 1860, vol. vii, pp. $42-43$. 
The gold-benring gravels along Long Island Creek and some of its tributary branches have been worked, and gold nuggets worth $\$ 20$ to $\$ 25$ were found on one of the properties a short distance up the creek from the Page mine. ${ }^{a}$ Placer mining is said to have been carried on as late as 1865 .

About 11/2 miles up strenm from the Page mine there are several openings and a tunnel 100 to 200 feet in length which are said to have been made by Commodore Stockton. Credner states that a series of lenticular quartz concretions were exposed by an incline on top of the hill. The ore was a very hard, sandy quartz, carrying free gold in minute particles. Another quartz vein, nearly 60 feet wide, was exposed by prospecting pits but the ore was very poor. ${ }^{b}$

On several properties lying $11 / 2$ to 2 miles north of Wilmington a little gold has been found in the placer gravels along the branches, and some quartz veins in that vicinity have been prospected by openings now caved, but all of the work seems to have been very superficial.

\section{The Snead Mine.}

Location.-The Snead mine is situated in Fluvanna County, 1 mile north of Fork Union, and is about 3 miles northenst of Fork Union station on the Virginia Air Line Railway.

History According to Credner the mine was first opened in 1838 and worked for nine months, during which time it yielded $\$ 6,0000^{\circ}$. The ore was treated in a primitive stamp mill operated by water-power, and much of the gold is said to have been lost in the tailings. Hamilton states that the mine was worked until $1850 . d$ The vein was opened by a shaft 25 feet deep, several open cuts along the outcrop, and a tunnel. An attempt to reopen the mine was made after the close of the war, and in 1881 the chlorination process of extraction was tried.c ${ }^{\circ} N_{0}$ work has been carried on for many years and the old workings are caved and inaccessible.

Geology.-The vein is located very close to the contact between the sedimentary rocks and the granite. On the west side of the vein near the

aCredner, H., Op. cit.

bCredner, H., Op. cit.

cCredner, H., Op. cit., p. 58. lHamilton, J. R., The Natural Mineral Wealth of Virginia, Harper's Magazine,
1805, vol. xxxii, pp. 32.42. cHotehkiss, Jed., The Tellurium Mine and Virginia Gold Mining, The Virginias,
1881, vol. ii, p. 85. 
branch that flows through the property, knotted schists are exposed that are identical with those in the bluffs at New Canton. The rock is bluishgray, fine-grained, and contains pseudophenocrysts of garnet and biotite 1 to $1.5 \mathrm{~mm}$. in diameter.

The granite on the east side of the vein is a medium-grained gneissic rock composed for the most part of feldspar and quartz; white to light gray in color, with large black blotches of biotite in small flakes. Under the microscope the soda-lime feldspars (oligoclase) are seen to be dominant over the potash feldspars (chiefly orthoclase). Some microperthite is present. Quartz occurs in irregular grains showing slight optical distortion and contains fluid-filled cavities, zircon, and rutile needles. The biotite is greenish-brown in color and shows strong absorption. Tourmaline occurs in occasional light brown prisms. Much carbonate, a little cllorite, and epidote are present as secondary minerals.

The vein is 3 to 6 feet wide and runs in a northenst-southwest direction, the dip being about $65^{\circ}$ toward the east. Credner states that the vein consists of hard white quartz, "containing sulphurets of iron, copper, lead, and zinc, and also oxide of iron, phosphate of lead, carbonate of copper and free gold." Hamilton mentions the presence of argentiferous galena.

\section{The Hughes Mine.}

Location.-The Hughes mine comprises a tract of 275 acres located in Fluvanna County on the Virginia Air Line Railway about 2 miles northeast of Fork Union station and $21 / 2$ miles southwest of Carysbrook.

History.-This mine was first opened in 1836, but for many years it changed hands frequently and very little development work was done. - The last period of operation began about 1895 and continued until the spring of 1906 , since which time the mine has remained idle. During this period the mine was developed by the Hughes Gold Mining and Milling Company to a depth of 115 feet, and an elaborate plant installed to treat the ore. .

Equipment.-The surface equipment consisted of a double cylinder steam hoist at each of the 2 shafts; a boiler house, mill, and cyanide plant. The mill building contained 2 batteries of 5 stamps each, amalgamated copper plates, and 4 Frue concentrators. The concentrates which carried 60 per cent. of the values were roasted and the gold extracted by treatment with cyanide solutions, while the tailings from the stamp mill were cyanided raw. The extraction is said to have been over 90 per cent. and the cost

$a$ Credner, H., Op. cit. 
of mining and milling a little over $\$ 4.00$ per ton. At present the mill is partly dismantled and some of the inachinery has been removed.

Underground development and description of veins.-According to Mr. Bugbee, who was general manager for the Hughes Gold Mining and Milling Company, the underground development work has been limited to 3 veins, two of which strike in a northeast-southwest direction parallel to the country rock, while the third running in an east-west direction cuts across the rock formations and intersects one of the other veins. The figures given below were taken from a prospectus issued by the Hughes Gold Mining and Milling Company in $\mathbf{1 9 0 5 .}$

Shaft No. 1 was sunk to a depth of 40 feet on the larger vein, a level was driven from the bottom of the shaft 140 feet southwest along the vein, and more than 50 feet of ore above this level has been stoped and milled. A mill run on 585 tons of this ore is said to have given a gross value of $\$ 9.00$ per ton. The vein has been proved by surface pits for 1,500 feet along the strike and has an average width of $21 / 2$ feet.

Shaft No. 2 was sunk to a depth of 110 feet on a second vein about 800 feet southwest of the first, and levels were driven at depths of 60 and 110 feet, respectively. From these levels cross-cuts were driven to reach the third vein 128 feet from the shaft. The second vein has been stoped out fiom the 60 -foot level to the surface. It averaged $1 \frac{1}{2}$ feet in thickness between the extremes of 1 and 3 feet, and the average value is given at $\$ 20.00$ per ton. The third vein, which has been developed for 230 feet along its strike, varies from 1 to 4 feet in width, averaging 2 feet, and is said to be worth $\$ 13.00$ per ton. In addition to the veins mentioned above 4 other veins have been prospected by surface pits and found to contain good values in gold.

Geology of veins and country rock.-At the time this property was visited the underground workings were filled with water and therefore inaccessible, so that it was not possible to examine the veins and wall -rock in place. The ore found on the surface is chiefly vein quartz, varying from coarsely crystalline to saccharoidal in texture, and in places it contains much pyrite. Fine flakes of light green chlorite are frequently present in the quartz chiefly along fractures, and chloritic schist containing pyrite was found attached to some of the ore.

The wall rock, as indicated by material found on the shaft dumps, is a greenstone schist derived from an igneous rock, probably a diorite porphyry. In the hand specimen it varies from light to dark green and contains eyes of light blue opalescent quartz, ranging up to $0.5 \mathrm{~cm}$. and 
over in diameter. In thin section (Spec. 36) ${ }^{a}$ the large quartz eyes show optical distortion and some granulation. Rutile needles are occasionally present as inclusions. The ground-mass is composed of soda-lime fèldspars, quartz, chlorite, epidote, zoisite, sericite, and a little titanite. The minerals show the effects of mashing, and the feldspars are extensively altered to saussurite and chlorite.

With the exception of the veins belonging to the Gold Hill system, this is the only mine in the district where gold-bearing veins have been found in rock of igneous origin. A short distance west of the veins ferruginous quartzites occur which are similar to those found interbedded with the schists in many localities throughout the area. At several places on the property pieces of almost pure magnetic iron ore are present on the surface, and some specimens ${ }^{b}$ were seen which have the appearance of a hematite breccia recemented with magnetite and hematite. The magnetite occurs in masses that are composed of small grains and octahedral crystals ranging up to $2 \mathrm{~mm}$. in diameter.

\section{MINES IN BUCKINGHAM COUNTY.}

\section{The London and Virginia Mine.}

Location.-The London and Virginia mine, or London mine as it is sometimes called, is located about a mile north of Dillwyn, a station on the Buckingham Branch of the Chesapeake and Ohio Railway. It joins the property of the Buckingham mine on the southwest.

History.-This property was first known as the Eldridge mine, and it was worked for a number of years by Mr. Eldridge before being sold to the London and Virginia Gold and Copper Mining Company, which was formed in London and incorporated in Virginia in 1853.

At first most of the ore was derived from open cuts, which were carried to a depth of 20 to 40 feet, and extended for a distance of 150 yards along the outcrop. Later, shafts were sunk proving the vein to a depth of at least 150 feet, and underground mining was extensively carried on. Operations were being conducted at the same time on the adjoining property, known as the Buckingham mine, and the two mines were connected underground by a continuous drive along the vein.

The mill used by Mr. Eldridge to pulverize the ores was located some distance north of the mine and operated by water-power. This mill was

aThis thin section was made from a specimen collected by Dr. J. S. Grasty.

bSpecimens collected by the State Geologist, Dr. Thomas I. Watson. p. 128 .

olVhitney, J. D., 'The Metallic Wealth of the United States, Philadelphia, 1854, 
in operation for about $15^{\circ}$ years, and Mr. Partz, in 1854, stated that there were at least 200,000 bushels of tailings lying on the ground, which could be advantageously worked over a second time. ${ }^{a}$ Later a mill was built a few hundred yards southeast of the vein, and the pile of tailings, which remains to this day, is mute evidence of an industry long since suspended. The property was closed down 5 or 6 years before the Civil War, and since that date active mining has not been resumed, but it is said that the old piles of tailings have been reworked at a profit, and $\$ 10,000$ extracted from them.

Descriptive geology.-The London and Virginia "vein," or "bed" as it has been variously called, has been opened up for practically the entire distance across the adjoining properties of the London and Virginia and the Buckinghani mines, and there are numerous shafts and pits located along its line of strike for a distance of several miles. Since the greatest amount of development work has been done on the two properties above mentioned, and since the character of the ore and the structural relations of the enclosing country rocks are essentially identical wherever they hare been observed; a single detailed description will suffice for both the London and Virginia and the Buckingham mines, and in the case of other properties located along the same vein only the variations from this description will be noted.

The London and Virginia vein is situated in a series of fine-grained schists and schistose quartzites, all of which are probably sedimentary. in origin. The formation has an average strike of N. $40^{\circ}$ E. and dips at a steep angle toward the southeast, in places being practically vertical. While there are few outcrops in the vicinity of the mines, the material on the dumps and the rocks exposed in the open cuts, which are almost continnous along the outcrop, together with the descriptions of the mines by Ansted, Henwood, and others, who examined, them when they were accessible, furnish sufficient facts to make possible the drawing of general conclusions in regard to the character of the ore, and the relation of the ore deposit to the surrounding rocks.

Henwood states that "a rather fissile and somewhat contorted clayslate, of homogeneous texture and leaden lue-the lowest rock observed in the neighborhood-is succeeded by a narrow band of whitish quartzose mica-s]ate, frequently interspersed with talc [probably sericite]; the auriferous deposit which succeeds is overlaid by thin lamellar greenishwhite chloritic talc-slate [sericite-schist] now and then flecked with 'mica."

aPartz, A., Examinations and Explorations on the Gold-Bearing Belts of the Atlaintic States, Mining Magazine, 1854, vol. ii, p. 380 .

bHenwood, W. J., Observations on Metalliferous Deposits, Irans, Royal Geol. Soc. of Cornwall, $187 i$, vol. viií, p. 376 . 


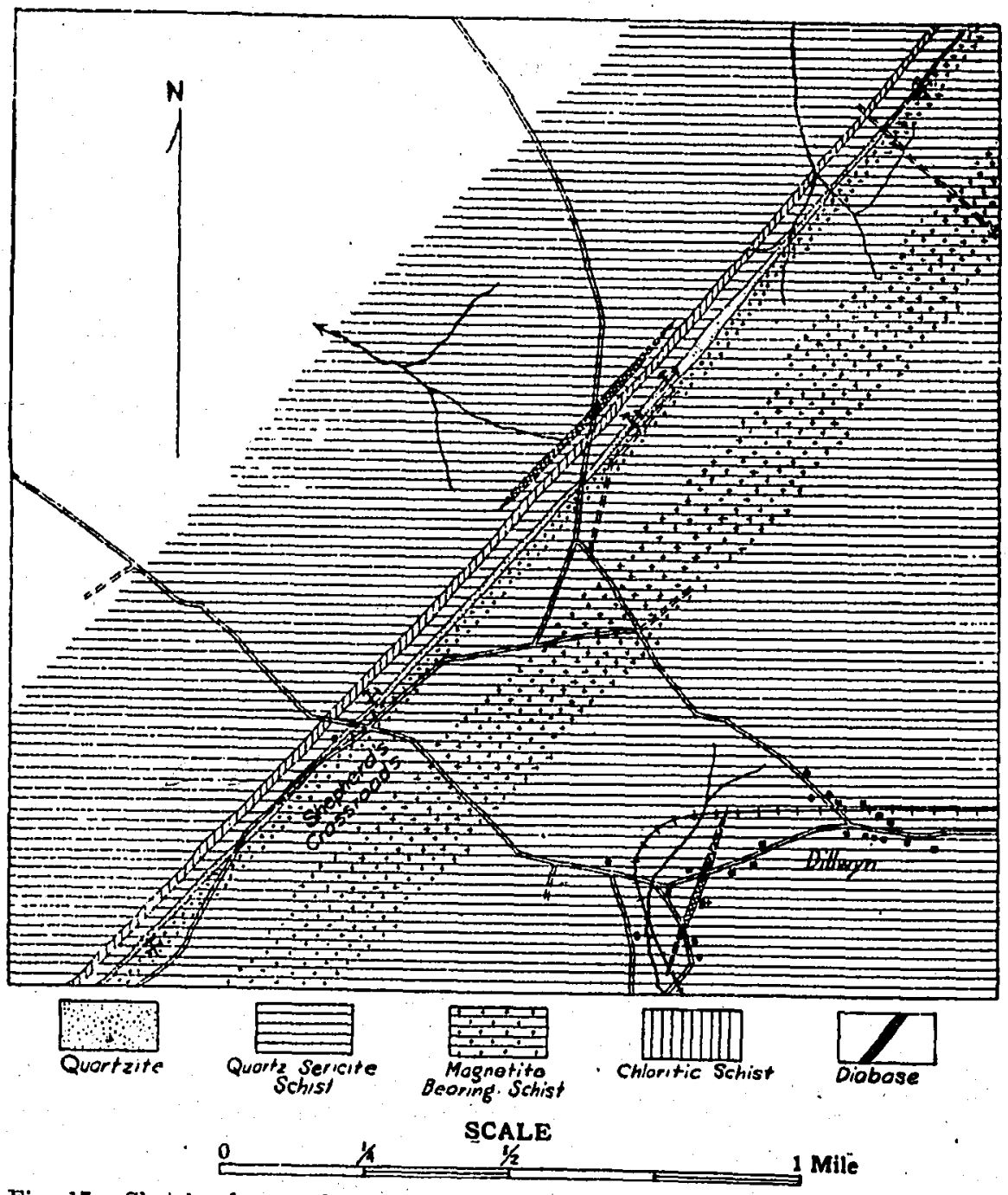

Fig. 17.-Sketch of map showing surface geology and locntion of mines and pros. pects along the strike of the London and Virginia vein, in the vicinity of Dillwyn.

A rock (Spec. 340) probably corresponding to the lead-colored slate mentioned above was found by the writer at the Buckingham mine, on the dump of a small pit which is located on the west side of the road crossing the property, and about 100 yards northeast of the outcrop of the vein. This rock is a chloritic schist varying somewhat in granularity but 
usually fine-grained. The dominant type is a dark gray schist in which most of the minerals are too fine for megascopic identification. It is cut by frequent fracture lines along which a little epidotization has taken place. Sericite, quartz, and chlorite can be identified with the aid of a pocket lens, and the rock contains much fine-grained magnetite, a little pyrite, and is closely sprinkled with small pink garnets, less than $0.5 \mathrm{~mm}$. in diameter.

Apparently the same chloritic schist as that just described crosses the road 125 yards northeast of Shepherd's Crossroads. While much weathered at this point the rock does not appear to be more than 50 or 60 yards wide. Northwest of this bed no exposures were found but the residual decay indicates that, for some distance, the country rock is for the most part a light-colored quartz sericite schist.

About 50 yards southeast of the rock described above, and 50 yards northwest from the outcrop of the vein, there is an old shaft or pit, now caved, but the dump contains some comparatively fresh rock (Spec. 341). It is a yery fine-grained quartz-sericite schist, pure white in color, which breaks readily along the cleavage planes, exhibiting a bright lustrous surface due to minute flakes of sericite. The rock is cut in two or more directions by closely spaced joints that cut the planes of schistosity at an oblique anglé A-few grains of opalescent quartz, $0.75 \mathrm{~mm}$. in diameter, and very fine grains of pyrite are the only minerals that can be distinguished megascopically.

In thin section under the microscope the rock is seen to consist largely of small quartz grains, the spaces between them being filled with a clear colorless mineral without cleavage and having a much lower index of refraction than the quartz (probably albite or orthoclase feldspar). Small flakes of sericite occur, mostly segregated in separate bands. There are also narrow bands or veinlets of quartz, slightly coarser grained than the rest of the rock, and the frequent association of these with pyrite suggests that they may in part be due to the circulation of solutions, rather than to recrystallization without migration of the mineral particles. Gas- and liquid-filled cavities are present in the larger quartz individuals. The pyrite ranges up to $0.2 \mathrm{~mm}$. or over in diameter, but most of it is much finer. A little titanite is present in small grains.

The quartz-sericite schist by decrease of sericite passes into a finegrained schistose quartzite, , which usually carries more or less sericite. In places the change from schist to quartzite is quite sharp, but the fact that the two rocks are contemporaneous and have had a similar origin 
can not be doubted. In the vicinity of the vein both the quartzite and schist are heavily impregnated with pyrite.

West of the vein, the rocks in places contain much magnetite. Some of the quartzite carries fine-grained magnetite and hematite, and on the surface, near the outcrop of the vein, pieces of biotite schist were found which contained numerous well-formed octahedra of magnetite. This rock is fine-grained, dark gray to black in color, and is composed for the most part of biotite, quartz, numerous reddish-brown garnets, and, in places, much magnetite in perfect octahedral crystals about $1 \mathrm{~mm}$. in diameter. In the different laminæ the proportion of these minerals varies somewhat and a little sericite may also be present. The rock is cut by a number of bands or veinlets of fine-grained quartz, which are usually parallel to the schistosity.

Southeast of Shepherd's Crossroads 150 yards, a fine-grained sericite schist outcrops in the road. It has a strike of N. $40^{\circ}$ E. and dips steeply to the southenst. The rock is composed essentially of fine-grained white sericite with little if any quartz, and contains numerous small iron-stained cavities left by the oxidation and removal of pyrite or magnetite. For a distance of several hundred yards southeast of this point, while there are no exposures, much magnetite is concentrated on the surface, and it has probably weatherce out from magnetite-bearing schists essentially similar to those already mentioned.

About 100 yards northwest of the vein, where it outcrops at the Buckingham mine, a diabase dike about 75 feet wide crosses the road in a northeast-southwest direction, but could not be traced for any great distance along the strike. A short distance west of the road a small pit furnishes exposures of the fresh rock. It is a coarse-grained, olivine-bearing rock, with marked ophitic texture. The feldspars are 3 to $4 \mathrm{~mm}$. long and twinning is easily detected with the naked eye. It is unlikely that this rock has in any way influenced the ore deposits.

Description of vein.-Since most of the vein exposures have been rendered inaccessible through the caving of old workings it is not now possible to examine the ore-body in detail, but Henwood gives the following description:

"The metalliferous bed, conforming to the-dissimilar flexures of the rocks on opposite sides, varies in width from 3 to 20 feet on the northeast, but 4 to 5 only toward the southwest. 'The northeastern portion consists, near the surface, of granular, massive, and cellular quartz; . sometimes embedded in, but frequently mingled with, earthy brown iron ore. Traces of galena occur at intervals; and small drusy cavities often afford crystals 
of the phosphate of lead and of selenite. The quartzose parts contain bodies of friable iron pyrites; of which the most deeply seated are the largest and most numerous. These . . . enclose isolnted masses of copper-pyrites; invested occasionally with copper-glance, but more generally with earthy black copper ore. ${ }^{\text {a }}$ The southwestern portions include many unconnected, angular blocks of slate; of all which the composition resemble, and the planes of structure conform to, the compositions and structures of the rocks in their respective neighborhoods. Except in this particular, and that massive quartz is more abundant, the southwestern parts differ but little from the northeastern. ... . The earthy brown iron ore and the quartz are slightly auriferous when separate; but when united in certain manners and proportions-more easily recognized than described-they frequently enclose small nuggets, thin plates, and crystalline grains, united by threads of gold; which constitute from 0.0000056 to $0.00000 \% 0$ of the ore extracted."

According to Partz the oxidized or "soft ores" extended to a depth of 20 to 40 feet "where the slate became hard and solid on account of the undecomposed auriferous pyrites in it" ${ }^{\circ}$ and Ansted states that "about 80 feet down from the surface threads of copper ore were found consisting of copper pyrites mingled with iron pyrites which forms the staple."d

The sides of the old open cuts from which the ore was taken frequently furnish exposures of dark iron-stained quartzite, usually containing small cavities due trin the removal of pyrite. At the Buckingham mine a large mass of this quartzite remains standing in the center of the opening, ore having been removed from either side, and the walls of the cut are of the same material. Where the surface has not been disturbed there are in places outcrops of quartzite in line of strike with the old workings.

The ore found on the dumps and in the vicinity of the mine which came from the deeper workings is mostly fine-grained, white quartzite with more or less disseminated pyrite. White quartz-sericite schist similarly

- impregnated with pyrite also occurs, but does not appear to be as plentiful at the Buckingham and London and Virginia mines, as at some other localities along the strike of the vein.

aThe following note is given by Henwood on page 376 of the publication previously cited:

"This ore afforded 0.230000 its weight of copper

0.001142 its weight of silver 0.000000 its weight of gold

Johnson and Matthey, Prospectus of the London and Virginia Company, p. 2."

bHenwood, W. J., Op. cit., pp. 376 and 379.

oPartz, A., Op. cit., p. 370 .

aAnsted, D. T., The Alleghnnies and the Gold District of Eastern Virginia in Scenery, Science and Art, London, 1854, p. 287. 
A specimen (342) found on the dump at the Buckingham mine shows the quartzite in contact with the quartz-sericite schist. The quartzite is a white, fine-grained, even-granular rock, impregnated with fine crystals of pyrite; and a little sericite in minute flakes can be distinguished on fracture surfaces approximately parallel to the schistosity. The schist is composed of the same minerals as the quartzite, the difference being in their relative proportions; sericite is very prominent, though in this specimen quartz is probably the dominant mineral, and pyrite is more abundant than in the quartzite. The contact between the two rock types while slightly irregular is quite sharp, and makes an angle of about $40^{\circ}$ with the schistosity of the rock. The pyrite is uniformly disseminated, except that it is more plentiful in the schist than in the quartzite, maling up perhaps 10 or 15 per cent. of the former and not more than 4 or 5 per cent. of the latter.

In thin section under the microscope the quartzite is seen to be com-. posed of small clear, interlocking grains of quartz showing no optical distortion, idiomorphic crystals of pyrite ranging from dust-like particles up to crystals $1 \mathrm{~mm}$. in diameter, and a few flakes of sericite. Occasional scattered crystals of orthoclase and acid plagioclase may be observed, and in places interstitial space between the quartz grains contains a light brown or colorless to cloudy mineral which is isotropic, and has a low index of refraction. At is probably some variety of opal. The quartzite has undoubtedly undargone extensive recrystallization, and the pyrite which impregnates the rock is probably secondary, replacing some of the quartz.

Only a very little massive vein quartz can be seen on the dumps, but several pieces of quartzite were found cut by small veinlets of massive quartz, ranging up to several inches in thickness. One specimen (343) shows a vein of massive quartz, 2 to 4 inches wide, which contains feldspar, nearly white in color with a slightly pinkish cast, and difficult to distinguish at a glance from the quartz. The feldspars occur partly in single individuals 1 to $2 \mathrm{~mm}$. in diameter and partly in clusters having an area of $2 \mathrm{~cm}$. or more. Occasionally coarse multiple twinning can be distinguished with the naked eye. 'The quartzite and schist in contact with these veinlets are heavily impregnated with pyrite, but the vein quartz contains comparatively little of this mineral.

In addition to the minerals mentioned in the above descriptions, several others have been reported by various writers. Partz states that "in one pit we found several specimens of fibrous (asbestiform) actinolite. . . Specular ore of a great variety, in form and color, is frequently met with. 
There were shown to us pretty specimens of heavy spar (sulphate of barytes) and talcite, taken also from these mines."

Genth found $a$ mineral associated with quartz and auriferous pyrite in ore from the London and Virginia mine which in composition corresponds to tennantite, the analysis being closcly similar to that of a specimen from the Jucud mines, given by Dana. ${ }^{b}$ The description of the mineral as given by Genth is quoted below.

"In granular masses; lustre metallic; color between iron-black and lead-gray; streak iron-black; opaque; $\mathrm{H}_{\mathrm{H}}=4$. Very brittle; fracture uneven-subconchoidal.

"B. B. in an open tube disengages sulphurous acid; and gives a sublimate of arsenious acid. On charcoal it emits fumes of an alliaceons odor, and fuses with intumescence to an iron-black, slightly magnetic globule, covering the charcoal with white incrustations. With fluxes it gives the reactions of copper and iron."

A preliminary analysis, made by dissolving the mineral in aqua regia, gave Mr. Wm. J. Taylor the following results: ${ }^{c}$

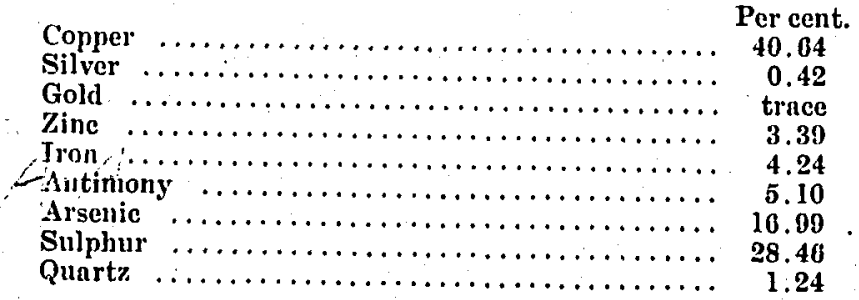

\section{The Buckingham Mine.}

Location.-The Buckingham mine is situated three-quarters of a mile northwest of Dillwyn, and on the northeast it joins the property of the London and Virginia, both being located on the same vein.

History.- In some of the earliest descriptions of this property it is referred to as the Wiseman mine. The Buckingham Gold Mining Company was organized to operate the property in 1853, and proceeded to develop the mine on a larger scale. ${ }^{d}$ The earliest work was limited to open cut mining and the surface openings were carried to a depth of 20 to 40 feet. Later 2 shafts were sunk and levels were driven to some extent along the

"Partz, A., Op. cit., p. 370:

DDana, E. S., A System of Mineralogy, 0th ed., New York, 1802, p. 140.

cGenth, F. A., Contributions to Mineralogy, Amer. Jour. Sci., 2d ser., 1855, vol. xix, pp, 18.10. p. 128

IWhitney, J. D., The Metallic Wealth of the United States, Philadelphia, 1854, 
vein, connecting through with the underground workings of the London and Virginia mine. The deepest shaft is said to have reached 180 feet, but practically all the ore mined came from the upper portions of the vein. It seems probable that two or more mills have been operated on the property, but the principal mill was located near the branch some distance northenst of the mine. The pile of tailings still in existence indicates that much ore was milled here. Austin writing in 1854 states that an nverage of 20 tons of ore were being crushed daily, yielding $130 \mathrm{dwt}$. of gold per day, and that during the previous yen 1,500 ounces of gold were obtained from the mine. Mining operations ceased several years before the outbreak of the Civil War and have not been resumed since that date. At present the shafts and underground workings are all caved, while the mills were destroyed years ago.

One of the most noticeable features both at the Buckingham and the London and Virginia mines is the absence of large dumps of waste rock. Practically all the material taken from the mines appears to have been put through the mills.

Geology of the ore-body.-As the character of the ore and the gcology of the deposit have already been referred to in describing the London and Virginia mine (see pp. 184-190) they will not be repeated here.

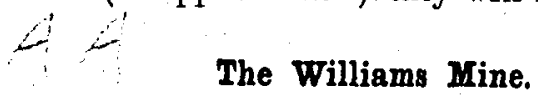

Location.-The Williams mine is located at Shepherd's Crossroads about a mile northwest of Dillwyn. It is less than three-quarters of a mile southwest of the principal workings at the Buckingham mine, and lies directly on the same line of strike (see map, p. 185).

Description.-There are several old prospect pits in this vicinity and recently a shaft has been sunk to a depth of perhaps 50 feet. The dump is covered with white quartz-sericite schist impregnated with .pyrite and is similar to that at the Buckingham mine already described. Only a very few small fragments of vein quartz are to be seen, indicating. the presence of occasional veinlets, mostly less than an inch in thickness. Pieces of this quartz sometimes contain a little pyrite, chiefly along their edges. The recent work is said to have been done with the hope of developing a pyrite mine. Some of the material on the dump carries as high as 80 or 85 per cent. pyrite. A thin section of this high-grade ore (Spec. 344) when examined under the microscope was found to consist of more or less idiomorphic crystals of pyrite, sericite, a few small grains of titanite, and little or no quartz. The pyrite seems to have replaced quartz in the sericite 
schist in preference to the other minerals, chiefly sericite, the latter being affected little if at all.

Passing southwest along the strike of the London and Virginia vein, old prospect pits, trenches, and a few shafts are found at short intervals for a distance of 10 or more miles, until the Bondurant mine is reached a short distance southwest of Andersonville. Most of this work was done over 50 years ago, and to-day the dumps are for the most part reduced to soil and overgrown with trees and bushes, so that there is very little to indicate the character of the material that was removed from the openings. The few written records of this early work confirm the data collected in the field, and indicate that the bed of quartzite, which where mineralized forms the greater part of the ore-body at the London and Virginia and Buckingham mines, is practically continuous throughout most of this distance. The quartzite varies somewhat in width and degree of mineralization, but is remarkably uniform in texture and appearance wherever observed. The outcrops are usually stained with iron and the rock more or less porous from the oxidation of pyrite, but in most cases the sulphides could not have been so abundant as in the vicinity of the London and Virginia, and Buckingham mines. While gold is reported to have been found at many of these places, it is improbable that the values anywhere along this southern extension of the vein approach those obtained from the ores at the London and Virginia, and Buckingham, when these. mines were being worked. At several of these properties surface washing has been attempted, but with little success, and no underground mining has been carried on.

\section{The Bondurant Mine.}

Location.-The Bonduiant mine is located about a mile southwest of Andersonville and about 10 miles from Dillwyn.

History.-Placer mining is said to have been conducted on this property as early as 1836, and some of the hillsides as well as the branches were washed for gold. A few years later it was leased from the owner, Mr. Bondurant, by Major Miller, who built a small stamp mill on the branch flowing through the property and worked a vein that outcrops on the hill about 400 feet to the south. A royalty of a tenth of the gold recovered was paid to the owner, and during the period of 10 months in which mining was carried on, he is said to have received $\$ 240$. Credner visited the property in 1865 and writes that "two parallel veins, 30 feet distant from each other, have been opened by excavations 20 to 25 feet deep, and by two shafts, 35 and 45 feet deep, respectively. One of these veins is two 
feet wide and the other four and a half feet. They stand nearly vertical, cross the property for three-quarters of a mile, and carry sandy quarts with much oxide of iron and free gold. 'The ores were crushed in a stamp mill and amalgamated in arrastras; but tailings only now mark the place where these works stood." $"$ a

About 1875 a small stamp mill was operated on the property for a short time, with what results is not known. In 1901, a tumnel starting near the creek was driven southenst for a distance of 410 feet, comnecting with three shafts having depths of 30,40 , and 71 feet, respectively, and from a point near its extremity a drive was opened for 96 feet southwest along a vein. Mr. Moore, who had charge of the work at the time, states that 5 parallel veins were encountered in the tunnel, the largest being 31 feet thick while the others ranged from 3 to 8 feet, and that another vein was located by a test pit on the opposite side of the creek. He says that assays were obtained running as high as $\$ 65$ per ton, the veins averaging $\$ 4.50$ per ton in gold.

Descriptive geology.-The few exposures observed in the vicinity of the Bondurant mine indicate that the country rocks are similar to those at the mines near Dillwyn, which have already been described in detail on pages 184-18\%. Quartzite, frequently containing magnetite and specular hematite, is the chicf rock found on the surface. When the property was visited by the writer in 1911 the greater part of the tumnel had been rendered inaccessible through caving, but the dump aftorded much information concerning the character of the rocks.

The so-called "veins"- appear to be beds of quartzite, more or less mineralized and cut by occasional veinlets or stringers of massive crystalline quartz, which frequently contain large crystals of muscovite. A specimen (312) of the quartzite cut by small lenses and stringers of vein quartz is shown in fig. 18. The quartzite is white when fresh, fine-grained, evengranular, and slightly schistose, the schistosity being parallel to the beclding. Looking at a piece that has been fractured across the schistosity, the rock appears to consist entirely of quartz with a little fine-grained pyrite, but on a fracture parallel to the schistosity, much white, fine, scaly sericite is visible. Lenticular eyes and stringers of vein quartz occur parallel to the bedding and also cut directly across, as shown in fig. 18. Fine-grained pyrite, much of which is in such small particles as to be almost invisible to the naked eye, is disseminated through the quartzite,

aCredner, H., Report of Explorations on the Gold Fields of Virginia and North Carolina, Amer. Jour. Mng., 1860, vol, vii, p. 72. 
being somewhat more abundant along the principal bedding planes and in close proximity to the veinlets, but the impregnation with sulphides does not appear to be nearly so extensive here as at the London and Virginia, and Buckingham mines.

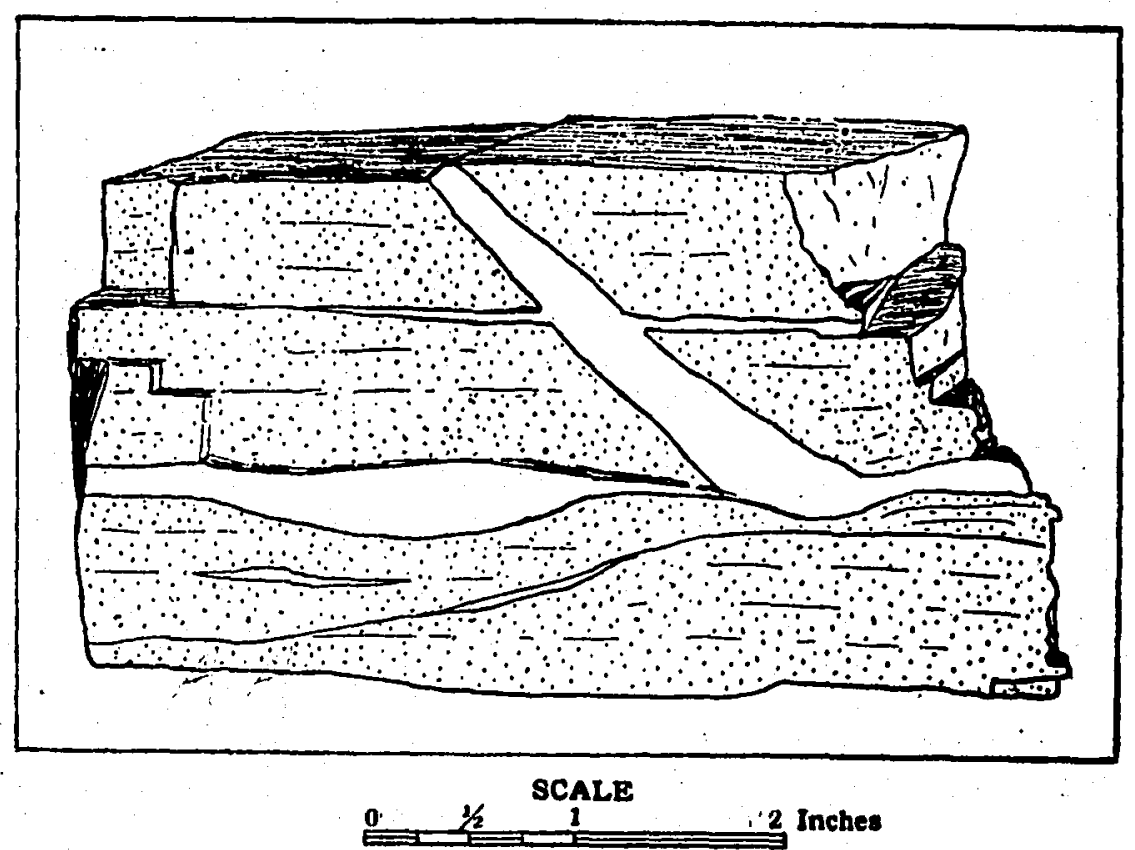

Fig. 18. - Sketch of specimen showing quartz veinlets cutting across bedding and schistosity of quartzite, Bondurant Mine.

The quartzite is interbedded with a fine-grained quartz-sericite schist, containing lenticular eyes of light blue opalescent quartz ranging up to $0.75 \mathrm{~cm}$. in length. The folia of the schist are wrapped around these eyes giving a knotted or bird's-eye maple like structure to the rock. Pieces of quartzite were found on the dump with the schist still adhering, and the contact between the two is not perfectly sharp but shows some gradation. Another piece of schist contained interbedded layers of quartzite that were only a half to an inch in thickness.

Some of the rock (Spec. 366) found on the dump is. intermediate in composition between the typical quartz-sericite schist of the district and the quartzite. It is a fine-grained, close-textured, light gray schist, with a faintly greenish tinge due to microscopic flakes of chlorite and sericite. In 
thin section under the microscope the minerals present, in the order of relative abundance, are quartz, pyrite in cubical crystals ranging up to about $0.5 \mathrm{~mm}$. in diameter, small flakes of sericite and chlorite, a few grains of magnetite, and occasional inclusions of zircon and titanite.

A little diabase (Spec. 368) was found on the dump. It is a finegrained, close-textured, dark gray rock in which no olivine could be identified with the aid of a pocket lens.

\section{The Anderson Mine.}

Location.-'The Anderson mine, located about a quarter of a mile south of Andersonville postoffice, lies just northeast of the Bondurant mine.

Description.-'The big bed of quartzite opened on the Bondurant can also be traced across this property by outcrops and old pits scattered along its line of strike. A shaft is said to have been sunk on the property to a depth of 50 feet, connecting with a tunnel 70 yards long, but both had caved before 1865, and to-dny there is little trace of their former existence. A little placer washing was done in the branches soon after gold was discovered, but that is the extent of the mining operations conducted on this property.

\section{The Flood Mine.}

Location the Flood mine lies southwest of the Bondurant and is separated from it by Willis River.

Description.-This property was formerly known as James Anderson's mine, and a little placer washing in the branches is said to have been carried on soon after gold was discovered in the district, but with what success is not known. A shaft and tunnel were opened prior to the Civil War, but they have long since caved, and nothing is now known as to the character of the vein exposed.

\section{The Gilliam Mine.}

The Gilliam mine adjoins the Flood mine and is the most southwesterly opening on the bed of quartzite, apparently continuous for so many miles northeast of the property. Whether it stretches yet further to the southwest is not known. According to Credner, who examined the property in 1865, when the "vein" was exposed by 7 cuts and a shaft 20 feet deep, the "vein" is standing vertical and has thinned to a width of only 4 feet. He states that the outcrop consists of brown oxide of iron with only a little quartz, which indicates that the quartzite is probably more heavily impregnated with pyrite than at the Bondurant mine. 


\section{The Burnett Mine.}

Location.-The Burnett mine is situated on the London and Virginin vein about three-quarters of a mile northeast of the London and Virginia mine and 11/4 miles north of Dillwyn.

History.-This property was formerly known as the Staples mine, and, when visited by Credner in 1865 , there was a shaft 54 : feet deep exposing "a multitude of lenticular quartz concretions in talcose [quartz-sericite] slate of bluish color which contain oxide of iron and free gold. 'The bushel, or one liundred pounds of this ore, is worth one dollar." $a$. The London and Virginia vein was not opened on this property until 1881, when the Burnett Mining and Milling Co. began development work. A shaft was sunk to a depth of 80 or 90 feet and a short tunnel driven from the southwest along the vein to connect with the shaft. There was another shaft a few yards northeast and a number of pits, all of which are now caved. The mine was worked during 1881,1882 , and a part of 1883 , but has since been idle.

A mill was located 300 to 400 yards west of the mine on the west side of a large branch. It consisted of 3 batteries of 4 stamps each. The mortar boxes were of cast-iron, while the stamps had square wooden stems with cast-iron shoes. The mill burned some years ago, but the charred stiumps of the stems can still be seen standing in the batteries. There is quite a large tailings pile below the mill, but it is said that most of the ore milled was hauled from the London and Virginia mine.

Descriptive geology.-The country rock, as indicated by the dump and by rock in place in the shaft, is a white, lustrous quartz-sericite schist impregnated with fine-grained pyrite, similar in every way to the rock occurring on the northwest side of the vein at the Buckingham mine. The "vein," exposed in the shaft, is a bed of quartzite 3 to 4 feet thick, having an approximate strike of $\mathrm{N} .45^{\circ} \mathrm{W}$. and a dip that is vertical or steeply inclined toward the southeast. The quartzite is very schistose and contains considerable sericite. In most places near the surface it is colored dark brown by the oxidation of pyrite, which has left small cavities in the rock. This ore is similar to that at the London and Virginia and the vein has been traced from one mine to the other by means of surface cuts, outcrops, and float.

aCredner, H., Report of Explorations on the Gold Fields of Virginia and North Carolina, Amer. Jour. Mng., 1809, vol. vii, p. 72 . 
The Hobson Tract.

The Hobson tract, formerly known as the Morton mine; lies between the Burnett mine and the London and Virginia. According to Credner a 40-foot shaft was sunk on the Lonclon and Virginia vein which here attains a width of 10 to 15 feet and exhibits the characteristic appearance of the quartzite where the pyrite has been thoroughly oxidized. 'The vein has never been worked to any extent on this property.

The Morton Mine.

Location.-The Morton mine is located half a mile west of Johnson, a station on the Buckingham Branch of the Chesapeake and Ohio Railway, and is about 7 miles northeast of the London and Virginia mine.

History.-This property was formerly known as the Hobson mine, and according to Pollard it was the first mine opened in the county. Surface washing was carried on in the early clays. When the property was visited by Credner in 1865 three parallel veins had been opened to a depth of 25 or 30 feet. He states that they are from 3 to 10 and in some places even 20 feet wide, and consist of granular massive quartz carrying oxide of iron and free gold. One of these veins is said to be the continuation of the London and Virginia vein. ${ }^{a}$ In 1906, two shafts, the deepest probably not more than 30 feet, ivere sunk on the property, but there is nothing on the dumps to indicate that either one struck a vein. When the writer visited the property in 1911 all openings had caved except the last mentioned shafts. There is an old dam on the small bianch west of the shafts, and on the opposite side the iuins of a building, said to have been used in washing gold. A little water-worn gravel was found around the building.

Geology.-'l'he mine is situated in an area of quartzites and schists, lying just west of the Arvonia slate belt and in line of strike with the London and Virginia mine which is 7 miles southwest. The two shafts sunk in 1906 were put down in a quartz porphyry, fresh specimens of which were exposed on the dump.

The rock (Spec. 360) is light gray to nearly white, slightly schistose, and is composed for the most part of feldspar and quartz. Occasional eyes of light blue to colorless, opalescent quartz, ranging up to $0.75 \mathrm{~cm}$. in diameter, are distributed through the rock. A few grains of ilmenite and pyrite, and along cleavage planes a little sericite and chlorite make up the remaining constituents visible to the naked eye. In thin section

$a$ Credner, H., Report of Explorations on the Gold Fields of Virginia and North Carolina, Amer. Jour. Mng., 1809, vol. vii, p. 58. 
under the microscope, the large quartz eyes are seen to be full of small zircon crystals, exceedingly minute rutile needles, and gas and liquid inclusions. The potash feldspars (orthoclase and microcline) are dominant over the soda-lime feldspar (albite-oligoclase or oligoclase) and orthoclase is more abundunt than microcline. 'There is also much microperthite present in the slide. The minerals show no granulation and little if any optical distortion, but the feldspars show some alteration to sericite, and to calcite, while the ilmenite is partly altered to leucoxene.

Between the Morton and the London and Virginia mine, and along the same general strike, a number of properties liave been prospected by means of pits and surface cuts, but no regular mining, aside from placer washing, has been conducted on any of them.

A property, formerly known as the Rough and Ready mine, adjoins the Morton mine on the southwest. At some time before the outbreak of the Civil War a shaft was sunk on a quartz vein carrying pyrite, and, in 1879, a pit opened on the property is said to have exposed a vein 6 feet in width which showed gold on panning.

On the Duncan tract, about $11 / 2$ miles west of Alpha, the gravel deposits along the branches were formerly worked for gold and a vein on the property was prospected a little but never worked.

Lying between the London and Virginia and the Duncan properties is a tract of land, which at different times has been known as Le Seur's or Apperson's mine, and on it a vein is said to have been explored and some ore raised before the war. Later prospecting was renewed, and in 1882 Campbell writes that 3 veins were exposed. The first, measuring 10 to 15 feet in width, consisted of a porous siliceous mass containing disseminated particles of gold. 'The second vein, about half a mile east of the first, was of whiter quartz but had not been well exposed. The third vein, which was still farther to the east, consisted of gold-bearing quartz disseminated in hard schistose rock like that at the Morrow mine. ${ }^{a}$

\section{The Norrow Mine.}

Location.-The Morrow mine is located about 31/2 miles southwest of Dillwyn and 2 miles east of Enonville.

History.-It was one of the first properties in Virginia on which underground mining was attempted and has had a long and varied history. When Prof. W. B. Rogers wrote his "Report of the Geological Recon-

aCampbell, J. L., The Virginia Gold Belt near the Richmond and Alleghnny. R. R., The Virginias, 1882, vol. iii, p. 120. 
noissance of the State of Virginia, 1835," Booker's mine, as it was then called, was already in active process of development. In its early history the property consisted of 2 separate mines on the same vein within 100 yards of each other, which were worked by W. M. Moseley and Co., and the Garnett Mining Co., respectively; but in 1852 they were consolidated under one management and incorporated under an act of the Virginia Legislature. For several years after this the property was controlled by an English company. In the early writings on geology and mining, the workings were usually referred to as the Garnett and Moseley mines, or the Booker mine, but since about 1880, when it was worked for a few years by the Morrow Mining Co., it has been known as the Morrow mine.

Several mills have been built on the property and much money has been wasted through the installation of expensive machinery, which after little or no use was pulled out to make room for later inventions. While the Garnett and Moseley mines were being worked separately there were two small mills in operation. In 1854, soon after the English company had bought the mine, Mr. Partza states that a new mill with 72 stamps was in operation, replacing the 24 . stamps that had previously been employed, and that the amalgamation was performed on two sets of shaking tables. When Credner visited the district in 1865 the mines were shut down, but he describes two mills he found on the property; one containing 4 shaking tables, nearly new, and a very large ball-crusher which had not been used; the other with 12 batteries of 3 stamps each, 72 shaking tables, arranged in 2 systems, and Chilian mills. ${ }^{b}$ In later years, a Howland mill, consisting of a flat circular disk revolving in an iron shell, was used to pulverize the ore, and the sulphides were concentrated on 2 vanners. An attempt was made in $1893-4$ to treat the sulphides by the Mears chlorination process, but it is said to have failed because of mechanical defects in the process used, though a satisfactory extraction of the gold was obtained. ${ }^{\circ}$ In 1911 there was no mill on the property.

Production.-Because of lack of records it is not possible to state the total amount of gold produced by this property. A prospectus of the Garnet Gold Mining Co., printed in 1852, gives the production of both mines for the previous year as follows:

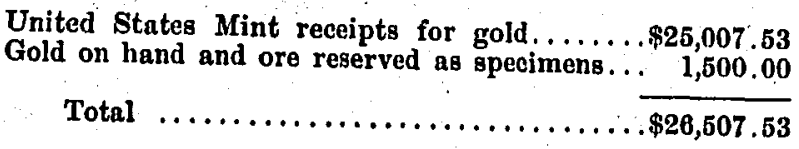

aPartz, A., Examinations and Explorations on the Gold-Bearing Belts of the Atlantic States, Mng. Mag., 1854, vol. ii, p. 378.

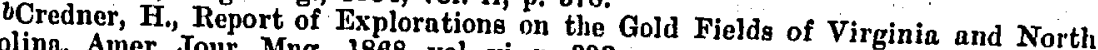
Carolina, Amer. Jour. Mng., 1808, vol. vi, p. 393. of Virgehling and Robertson, A Hand-Book on the Minerals and Mineral Resources
of 
Mr. W. J. Henwood gives the amount of gold derived from both mines for the yenrs 1850-2 inclusive.

Annual production of gold in pounds Troy.

\begin{tabular}{|c|c|c|}
\hline Yenr & Garnet mine. & Moseley mine. \\
\hline 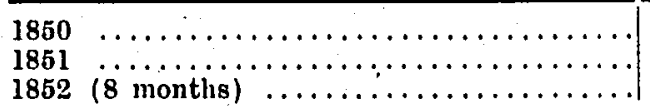 & $\begin{array}{l}30.75 \\
20.17\end{array}$ & $\begin{array}{l}97.02 \\
71.74 \\
31.10\end{array}$ \\
\hline
\end{tabular}

Over $\$ 60,000$ is said to have been recovered from the placer washings near the veins.

Underground development.-Before underground work was resorted to, most of the upper portion of the Booker vein was removed by open-cut surface mining down to a depth of 30 feet, and for a distance of over 400 yards along the outcrop. By 1853, it is said that 5 shafts used for hoisting, ventilation, and pumping had been sunk to an average depth of 100 feet, and connected by drives 350 feet in length. The vein had been proved for over half a mile by 4 or 5 shafts 30 to 50 feet deep, and by as many as 50 surface cuts. ${ }^{b}$ Later development work extended the underground workings, and a good deal of stoping was done, but none of the shafts seem to have been,carried below 115 feet. When the property was visited in the summer of 1911 , the openings had partly caved and none of them was accessible.

Descriptive geology.-The Morrow mine is situated in an area of intensely metamorphosed. schists and gneisses, which, for the most part, are probably derived from sedimentary rocks. At Tongue Quarter Creek about a mile southwest of the mine there is a large area of fine-grained, dark green, hornblende schists, and 2 miles southwest of the property are the bold outcrops of cyanite schist and quartzite that form Willis Mountain.

In the immedinte vicinity of the mine there are few rock exposujes, but the old shaft dumps furnish much information concerning the character of the country rock enclosing the ore deposits. These rocks are all schistose and usually show more or less banding; they range from light to dark gray and green in color, are usually garnetiferous, and frequently contain an abundance of calcium-iron carbonate, probably a variety of ferrocalcite. The latter mineral is finely crystalline and light brown in

aHenwood, W. J., Observations on Metalliferous Deposits, Trans. Royal Geol. Soc. of Cornwall, 1871, vol. viii, p. 382.

bThe Garnet and Moseley Mines, Virginia (Reprinted from a paper by "The Editor," in the Richmond Enquirer), Mining Mag., 1853, vol. i, pp. 164-167. 
color when fresl, turning to dark brown on weathering; it effervesces very slowly in cold dilute hydrochloric ncid; and on henting before the blowpipe becomes only slightly magnetic. Wet tests give heavy precipitates of calcium and iron, but little or no magnesium.

A thin section was made from a light gray, gneissic rock in which the carbonate was particularly plentiful. Megascopically the rock (Spec. 378) shows imperfect banding of the light- and dark-colored minerals; the lighter bands being largely composed of carbonate and quartz, while in the dark ones biotite is a prominent constituent. White mica, pink garnets, and a few small grains of magnetite and pyrite may also be recognized. Under the microscope, carbonate is dominant in the thin section, with quartz, sericite, biotite, soda-lime feldspar (andesine ?), and garnet following in the order named. Some of the quartz shows much optical distortion, but large clear grains of secondary quartz are also present. The feldspars are fresh and clear, and usually show multiple twinning after the albite law. The garnets show no suggestion of crystal form, and are simply gramular aggregates, intermixed with the other minerals, principally carbonate.

'There is much light gray schist (Spec. 3r9) on the dumps, in which the principal constituents distinguishable without the aid of the microscope are fine-grained quartz, sericite, scattered flakes of biotite, averaging $1 \mathrm{~mm}$. in diameter, and occasional eyes of opalescent quartz 5 or $6 \cdot \mathrm{mm}$. in diameter.

Another rock type (Spec. 376) occurring on the dumps, is a dark green and reddish-brown gneiss in which most of the minerals (especially mica and garnet) are very largely concentrated in narrow bands or lenses. Megascopically, the following minerals can be distinguished: Biotite, in black flakes 0.5 to $1.5 \mathrm{~mm}$. in diameter, which occur partly in narrow bands, the cleavage of the mica being at varying angles with the schistosity of the rock; garnet, in irregular lenticular masses $1 \mathrm{~cm}$. or more in thickness; fine flakes of sericite and light green chlorite; quartz; much finegrained magnetite; and occasional feldspars, 1 to $1.5 \mathrm{~mm}$. in diameter.

In thin sections under the microscope, much feldspar can be distinguished, partly a soda-lime feldspar with albite twinning, and partly a clear feldspar with low index of refraction and no twinning (albite or orthoclase). Much of the feldspar and quartz show optical distortion, and in places zonal extinction can be observed. In addition to the minerals already mentioned, much calcite was noted, and occasional fragments of zircon and titanite. Gas- and liquid-filled cavities occur in some of the quartz. 
Dark green hornblende is present in part of the schists, and some pieces are heavily loaded with the sulphides, pyrite and pyrrhotite. Some of the pieces of schist and gneiss contain lenses or stringers of quartz and carbonate, usually with a little white mica; and there is a great deal of rock (Spec. 373) on one of the dumps, consisting of dark-colored, finegrained schists, cut by numerous branching veinlets of quartz and carbonate, with some muscovite and light green chlorite. These veinlets range up to several inches in thickness, and often make up as much as 50 per cent. of the rock mass. This material is very similar to some of the "vein". stuff described by a number of geologists who have examined the underground workings. 'Thus, Prof. Campbell states that, "the 'vein,' as it is called, in which work was going on [at the time of his visit in 1881 or 1882], is at least 30 feet wide, and is composed of a schistose rock with injected quartz, forming in some places secondary veins and thin sheets, and at other points, apparently dispersed, with its accompanying auriferous pyrites, in the slaty beds of hard rock that make up the main mass of what is taken from the mine."a

\section{E. Springs}

w.

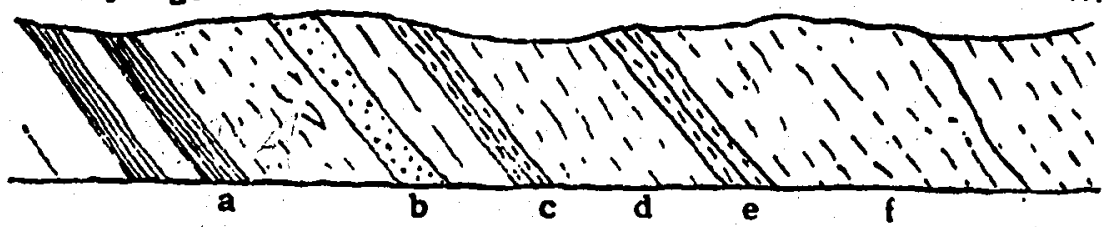

Fig. 19.-Section across the district worked for gold in the Morrow Mine. (After Ansted, Scenery, Science and Art, p. 289.) a, rotten schists with pipe clay; $b$, stentite; $c$, principal auriferous band called east vein; $d$, hornblendic rock;

$c$, upper auriferous band (west vein); $f$, overlying beds.

Prof. Ansted describes the "belt" of rocks in which the ore bodies occur and gives a geological section showing the structural relations of the rocks in their immediate vicinity. (See fig..19.) His description is as follows:

"The actual breadth of this belt I had no means of exactly ascertaining, but it certainly exceeds 200 yards, and is probably much greater. It is, however, subdivided, including distinct bands of mixed quartz threads and rotten red and yellow or greenish schists $(a)$. On these repose bands of talcose or chloritic schist, which pass into an imperfect steatite $(b)$, occasionally used as a firestone to line furnaces. All these are on the east or lower side of the series. In the middle, between the two well-marked. auriferous bands which next succeed, is a certain thickness of hornblendic greenstone $(d)$ hard, and tolerably compact. The eastern auriferous band
has been extensively worked at the surface.")

aCampbell, J. L., The Virginia Gold Belt near the Richmond and Alleghany R. R., The Virginias, 1882, vol. iii, pp. 120-121; Geology and Alineral Resources of the James River Valley, New York, 1882, pp. 00-100. Unsted, D. T., Scenery, Science and Art, London, 1854, Chap. 3, The Alleghanies
and the Gold District of Eastern Virginia, pp. 289-290. 
Henwood states that the rocks exposed in the mine contain "mica, tale [probably sericite], and chlorite in large but ever-varying proportions," so that one or the other may dominate in lamine only a few inches apart, or even in different portions of the same rock layer. ${ }^{a}$

Besides the "principal bed," Henwood mentions four other "auriferons beds," occurring in and immediately northwest of the mines, which "maintain tolerable parallelism; except where they are affected by unequal flexures of the adjoining rock; to the schistose structure of which they strictly conform." They vary from 4 to 18 feet in maximum width, but average much less, and "within short distances some of them divide, dwindle, and die away; occasionally, however, they reappear and again enlarge." $b$

The slates beneath the "principal bed" dip northwest at an angle of $40^{\circ}$ to $60^{\circ}$, but those above preserve the same inclination to a depth of 60 feet only, and thence downward dip $20^{\circ}$ to $30^{\circ}$. As the hanging-wall or northwestern side recedes from the foot-wall, and the "auriferous bed" between them becomes broader, it encloses lengthwise a wedge-shaped nuass of slate, which widening downward partakes in some measure of the mineral character of the surrounding "vein-stone," while in structure it coincides with the neighboring rocks. ${ }^{\circ}$

According to Prof: Ansted, "the enclosing rock, which within 20 feet of the surface is hardly to be distinguished from the vein, gradually changes below this point, and within a depth of 10 or 1.5 feet becomes a hard, compact talcose [probably quartz-sericite] schist, often containing fine garnets, and not infrequently iron pyrites. In this schist, at a smoll depth, are a multitude of quartz threads, and farther down these thrends come together, forming a distinct quartz band, often enclosing portions of the schist. 'The gold disseminated indifferently near the surface, amongst the quartz, rotten schists and enclosing walls, gradually collects together into threads, usually ranging with the schistose portions within the quart\% band. The walls are very distinctly marked, and easily separated, and are found to be no longer auriferous, while the quartz, of which the thickness amounts to 10 feet at a depth of about 100 feet from the surface, seems to
increase continually in value."

The appearance of the vein is shown in the generalized sketch (fig. 20), which is drawn from pieces of rock found on the dump, and is in accordance with the descriptions of several observers, who have examined the underground workings.

aHenwood, W. J., Observations on Metalliferous Deposits, Trans. Royal Geol. Soc. of Cornwall, 1871, vol, viii, p. 370 .

ubid., p. 380.

olbid., pp. 380-381.

ansted, D. T., Op. cit., p. 200 . 


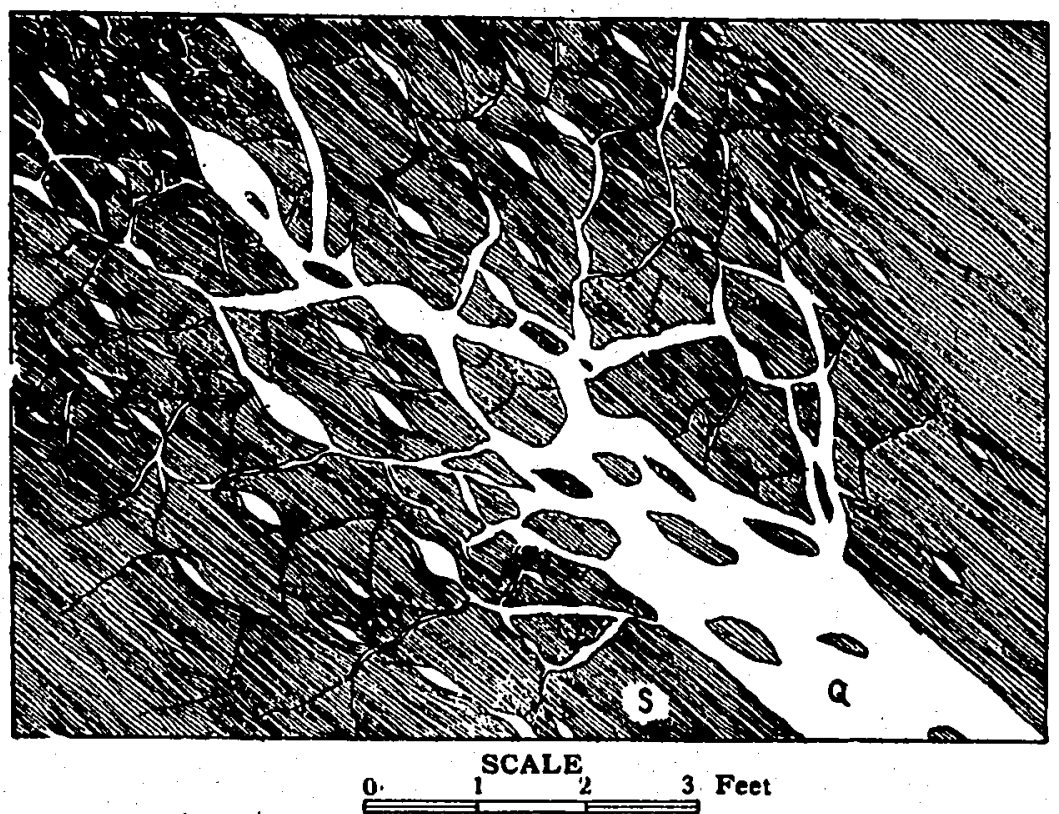

Fig. 20.-Sketch showing reticulated veinlets with inclusions of wall rock at the Morrow Nine. $Q$, quartz; $S$, schist.

Description of ores.-Quartz and schist, varying in relative proportions, always make up the greater part of the ore-body, but Henwood also mentions the presence of small quantities of feldspar scattered throughout, and in the deeper portions calcareous spar, pyrite, and crystals of common garnet. He states that veinlets of quartz, feldspar, and calcareous spar cut the metalliferous beds at intervals irrespective of their slightly foliated structure, which is generally parallel to the cleavage of the adjoining strata. Near the surface all parts of the rock-mass contain particles and grains of gold but at greater depths, in the "principal bed" flakes, granules, nuggets, and threads here and there intertwine the quartz with groups of golden filigree. It is stated that tellurium often accompanies the gold but is never abundant. According to Campbell the gold is said to carry a considerable percentage of silver. ${ }^{b}$

aHenwood, W. J., Op. cit,, p. 382.

- UCampbell, Op. cit. 
Henwood believes that there is a decrease in values with depth, and after calling attention to the gradual decrease in production for the years 1850-52 (see p. 200), during which time approximately the same number of men were employed in extracting the ore, states that, "these results show the proportions of gold to have been larger in the shallower and narrower, than in the deeper, wider, and flatter parts of the principal bed."

Selected samples are said to have carried $3 \mathrm{oz} .16 \mathrm{dwts}$. in gold, but ore from a depth of 90 feet in the Garnett mine yielded an average of 10.1 dwt., and from the Moseley mine an average of $8.1 \mathrm{dwt}^{b}$

Credner says that the gold-bearing beds are cut off by domes and ridges of diorite; but the mines were closed at the time of his visit in 1865, and he does not give his authority for this statement.o

Placers.-During the early history of the property the placer deposits were much worked, and over $\$ 60,000$ is said to have been recovered from the gravels near the reins. Henwood quotes Major Miller as writing that "a nugget of nearly 9 pounds, besides many masses of a few ounces each were mixed with grains of gold in the bed of a rivulet immediately sonth of the Garnett and Moseley mines."d

\section{The Seay Mine.}

The Seay property adjoins the Morrow mine on the west, lying between it and Enonville, and belongs to the same company.

The placer gravels were washed for gold and several quartz veins containing pyrite and gold were opened by cuts and small shafts. There was a mill on the property before the Civil War, but little mining seems to have been done. After the war a shaft is said to have been sunk to a depth of 150 feet but nothing further was done.

\section{The Greeley Mine.}

Location.-The Greeley mine, lying on the headwaters of Hatcher Creek. is situated about 11/2 miles southeast of Alpha, a station on the Buckingham Branch of the Chesapeake and Ohio Railway, and a mile southwest of Gravel Hill.

History-The placer deposits at the Greeley mine, formerly known as Ayres' mine, were worked during the early days of gold mining in this

aHenwood, W. J., Op. cit., pp. 282-283.

bIbid., pp. 282-283.

cCredner, H., Op. cit.

dHenwood, W. J., Op. cit., p. 384. 
county, and it is reported the branch gravels yielded much gold. Prospecting has been carried on at various times in the endeavor to locate the vein from which the placer gravels derived their gold, and many pits, trenches, and shafts have been opened with this object in view, but to-day they are all caved. There are several large trenches, leading toward the top of a hill, the largest being 30 to 40 feet wide, about the same depth, and several hundred feet long in a northeast-southwest direction. While these trenches look rather large for the purpose, they are said to have been cut while prospecting for the vein. When Credner visited the mine in 1865 a mill was being started, but it was probably never finished, and except for the placer washing no mining has been done on the property.

Veins and country rock.-Several veins were located by open pits and one of them is reported to have carried free gold, but the vein quartz exposed when the property was visited by the writer showed little evidence of mineralization.

The lack of outcrops on the property and in its immediate vicinity makes it difficult to draw conclusions in regard to the country rock. A few pieces of quartz-sericite schist are found on the surface, and at a distance of a mile or more northeast and southwest along the strike of the formations, schists and quartzites are exposed which appnrently belong to the same series as the rocks in the bluffs near New Canton.

One of the shafts is sunk in a gray granitic rock (quartz monzonite) which is distinctly schistose. The rock (Spec. 348) is fine-grained and even-granular, and a microscopic examination showed it to be composed of the following minerals, the order given being that of relative abundance: Quartz, biotite, feldspar, hornblende, calcite, garnet, chlorite, magnetite, zircon, and tourmaline. The feldspar corresponds to andesine in composition and shows albite twinning, and orthoclase if present is rare. The biotite is dark brown in color with strong absorption. Hornblende occurs in light to dark green crystals, with ragged ontline, and low interference colors. Calcite which is fairly abundant frequently shows multiple twinning. The garnets which are light pink in color show ragged outlines and contain numerous inclusions of the other minerals. Both biotite and hornblende show alteration to chlorite which is dark green in colos. Magnetite occurs in clusters of small grains and zircon is quite plentiful as inclusions. A prism of tourmaline is present in the slide. It is strongly pleochroic changing from reddish-brown to dark green.

Much of the rock is cut by veinlets ranging up to 2 inches or more in width, but mostly less than an inch. In places calcite forms one side. 
and quartz the other of a veinlet, but usually they are intermixed, quartz occurring in calcite and calcite in quartz. Often the veinlets are much contorted, and again they branch and intersect. The contact between the rock and the veinlets is not always perfectly sharp but shows a slight gradation. Occasionally large crystals of muscovite 4 or $5 \mathrm{~cm}$. in diameter are intercrystallized with the quartz and calcite. Where plentiful the flakes of muscovite meet one another at all angles, and the interstitial space is filled with quartz and calcite. Light-colored pyrite is present in the vicinity of some of the veinlets, occurring in cubes 2 to $3 \mathrm{~mm}$. in diameter.

\section{The Iightfoot Mine.}

Location.-The Lightfoot mine is situated on the southeast side of Slate River, 2 miles north of Arvonia.

History.-While this property is now better known as a copper mine (see p. 241) it was first worked for gold. It is said that the discovery of the mine was due to Geo. Fisher, who worked the property, for several years under lease. After the expiration of his lease it was worked successively by three different companies, who leased it from the proprietor, Mr. Lightfoot. The first of these companies is reported to have made $\$ 300$ to $\$ 400$ per day stamp-milling for gold. The second company confined its, work to surface washing, and the last company developed the copper deposits, shipping 100 tons of $\$ 80$-ore to Baltimore, before the mine was closed by the outbreak of the war in 1861. Since that time no work has been done on the gold veins and at present there is little trace of these former operations. In working the placer deposits, gold nuggets worth $\$ 20$ to $\$ 30$ are said to have been found.

Gold veins.-The country rock in this vicinity is a greenstone schist, which is described in detail on pages 49-51. Credner states that at the time of his visit, in 1865, two gold veins were exposed by pits and shafts which had partly caved. One of these was 4 feet wide and carried iron sulphide and free gold.

Gold has also been found on the Ford property (see p. 243). 


\section{CHAPTER VI. \\ GENETIC RELATIONS OF THE GOLD DEPOSITS.}

\section{INTRODUCTION.}

The genesis of ore deposits has frequently been regarded as a question of scientific interest only, but with increasing knowledge of the subject it is beginning to be of great practical value from an economic standpoint. The unraveling of the structural relations of ore-bodies, particularly in regions of extensive faulting, has long been recognized as invaluable to the miner, and there is a growing appreciation of the importance of ore genesis. A thorough understanding of the mode of formation and of the subsequent alterations which may have enriched or impoverished an ore deposit, is the only logical basis on which it is possible to predict the continuity and character of the ore-body in depth, or to indicate the probable location of other deposits that may not be exposed.

\section{Previous Theories.}

The first geologists to study the gold-bearing veins in this district advanced two-antagonistic theories to explain the formation and occurrence of the ore deposits, and both of these theories have had strong supporters. According to one theory, the veins were forcibly injected by igneous agencies into older rocks; and since the lines of least resistance were usually along planes of bedding and schistosity, the veins, as a rule, conformed to the structure of the enclosing formations, although in places they split up and cut across. This explanation was advanced and supported chiefly by Rogers (see page 10). The opposing theory was based on the assumption that the ore-bodies were layers or beds deposited contemporaneously with the enclosing rocks. This explanation as applied to the origin of Virgina gold veins seems to have been advocated first by Clemson and Taylor ${ }^{a}$, and was later supported by Silliman, Ansted, Credner, and others. Most of these geologists seem to have ignored the fact that some of the veins in places cut across the bedding of the country rock, but others, following Ansted, attributed this anomaly to changes brought about by "chemical agency" or by a "process of segregation" (see p. 11).

"Clemson, 'T. G., and Tayilor, R. C., The Gold Region of Virginia, Trans. Geol. .. Soc. Pa., 1835, vol, i, p. 300 . 
The facts established by the present report in many ways support the views advocated by Rogers but there are certain important exceptions which will be noted later. After examining, at the Tellurium mine, the bed of quartzite known as the "Big Sandstone" vein (see pp. 15\%-164), it is easy to understand how the early geologists came to regard the veins as sedimentary in origin, for this quartzite is at a glance closely similar to the auriferous quartz veinlets which it encloses.

\section{Types of Deposits.}

The primary gold deposits in this district may be divided into two principal types: (1) Veins accompanied by little or no replacement or impregnation of the wall rock, and (2) ore-deposits which have been formed chiefly through replacement-but there is apparently every gradation between the two extremes. Ores belonging to the first type consist essentially of quartz, with more or less feldspar and variable quantities of gold. The sulphides, chiefly pyrite, are always present in small quantities, but seldom average more than 1 per cent. In the ores belonging to the second type, pyrite is the most important constituent and chalcopyrite it fairly common. The veins belonging to the Tellurium system, particularly the "Micldle" vein, may be mentioned as typical examples of the first class. The veins at the Young American mine are also of this type, for though there has been in places considerable mineralization of the wall rock, it is nowhere extensive, and is usually in the nature of silicification of the country rock.

The typical replacement deposits were found only in the southern portion of the area in Buckingham County. The London and Virginia rein is an example of the latter class, and the New Canton ore-body probably represents an extreme variety of this type. Under a strictly logical trentment of the subject the genesis of the New Canton ores should probably be considered in this chapter, but because of their localization near an igneous contact, their insignificant gold content, and the fact that they have been worked chiefly for copper, it has been thought best to discuss them elsewhere (see pp. 257-259).

\section{MINERAL COMPOSITION OF THE VEINS.}

The consideration of minerals associated with gold is important, not only because of their possible value as indicators of the presence of the precious metal, but also for the reason that such minerals furnish the most reliable evidence bearing on the genesis of the ore-deposits. A table, 
summarizing the minerals which have been found in the gold-bearing veins of this district, is given below, together with the names of mines where they have been identified, and the authority for each instance cited. Both the minerals and the mines are listed in alphabetical order. The details in regard to any particular occurrence may be found under the description of the mine in chapter $V$. The table is limited to minerals found within the quartz veins, and no attempt has been made to list those occurring in the replacement deposits as that would necessarily include all minerals present in the wall rock. Common secondary minerals, undoubtedly derived from one of the primary minerals listed, are also omitted. 
List of minerals in the gold veins of the James River basin area, Virginia.

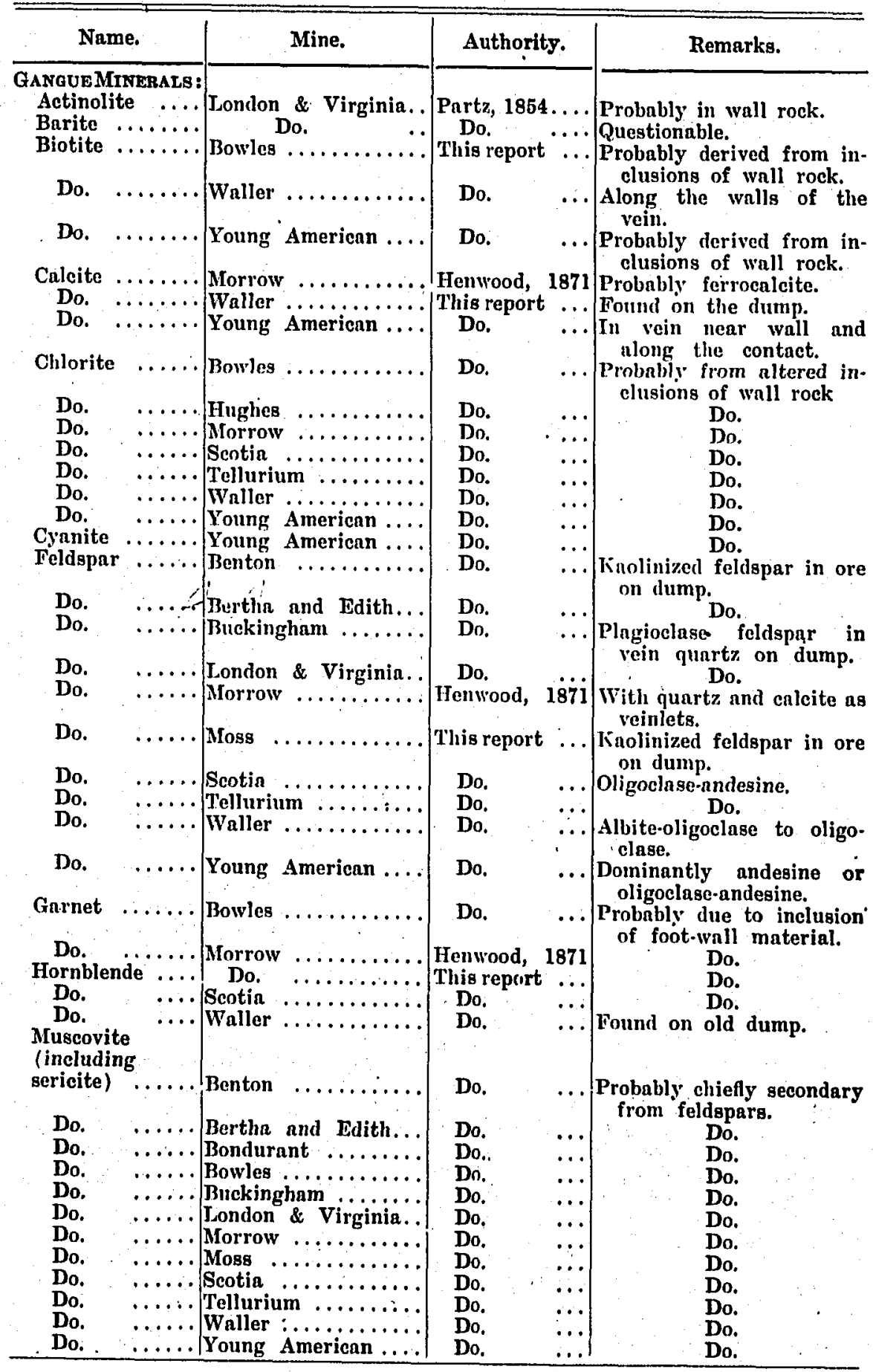


List of minerals in the gold veins of the James River basin area, Virginia(Continued).

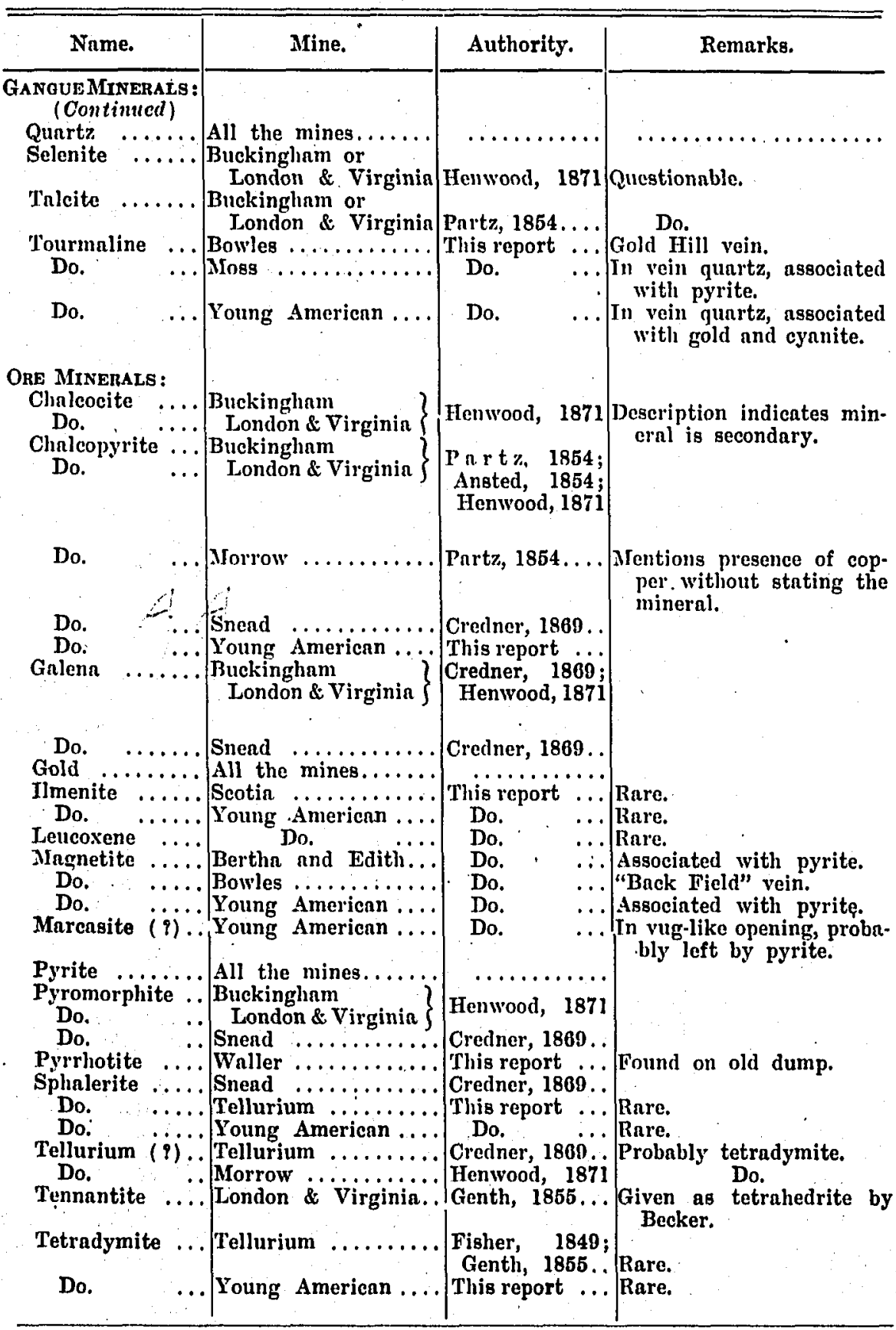




\section{Description of the Gangue Minerals.}

Quartz is always the most abundant gangue mineral. It varies from milky white and translucent to clear and glassy. It is coarsely crystalline, in places approaching saccharoidal in texture, and is apparently the same wherever it occurs in well-defined veins, lenses, or as a replacement mineral. Crystal faces are rare except along joint planes and in cavities left by the removal of pyrite, where they are probably due to the enlargement of primary individuals by deposition of a little secondary silica. Examined microscopically, the quartz frequently shows some optical distortion but little or no granulation or other evidence of crushing. The individual grains have irregular interlocking boundaries and average from 1 to $3 \mathrm{~mm}$. in diameter. Gas- and fluid-filled cavities are common, sometimes occurring in irregular branching and interlaced forms, but more often in smaller spherical and elliptical shapes, which are usually grouped in rows or planes that occasionally extend unbroken from one crystal individual to another.

Feldspar is the second gangue mineral in relative abundance, having been identified in all veins that were well exposed, and in places constitutes as much as $\mathbf{1 0}$ per cent. of the vein material. It occurs in angular crystals, ranging up to $1 \mathrm{~cm}$. or more in diameter, scattered through the quartz, but is usually much more plentiful near the walls of the veins. In some of the smaller veins, and in places. where quartz lenses narrow and pinch out (see fig. 14), feldspar is sometimes for a limited distance practically the only constituent. When fresh, the feldspars are white to light yellow or light pink, and are often difficult to distinguish from the quartz without careful examination. In the upper portion of the veins above water level the feldspars seem to be entirely kaolinized, but wherever specimens could be obtained, sufficiently unaltered for identification by optical methods, they proved to be soda-lime plagioclase, rangịng from albite-oligoclase to andesine. No orthoclase or albite could be distinguished in any of the veins. In thin sections under the microscope the feldspars commonly show albite twinning but many of them are entirely. unstriated. There is no evidence of optical distortion, granulation, or other pressure effects. In places a little sericite is present as an alteration product of feldspar, occurring in clusters of curved and radiating scales, but kaolin is the chief secondary minernl. The feldspars are probably of earlier crystallization than most of the quartz.

White potash mica is one of the important gangue minerals, apparently occurring in all of the veins. Some of it is in large flakes such as are usually called muscovite, while much is in the form of shreds and scales, 
evidently secondary in origin, and commonly designated as scricite. Sericite is a prominent constituent of the wall rocks and is especially plentiful in some replacement deposits.

Biotite and chlorite are frequently present in the reins, but their occurrence is such as to suggest that they were chiefly if not entirely formed from inclusions of country rock through alteration by vein-forming solutions. The chlorite is partly secondary after biotite and partly derived from hornblende; it is doubtful if any of it is an original constituent of the yeins. Garnet and hornblende rarely occur within the quartz veins and where identified were found close to the walls. These four minerals are occasionally prominent in the wall rock, and their occurrence and distribution indicate that their formation was chiefly due to metamorphic agencies accompanying the formation of the veins.

Black prisms of tourmaline, usually arranged in radiating groups, occur in some of the gold-bearing veins, and one specimen was found showing visible gold resting on tourmaline (see p. 131). Tourmaline was seen in association with auriferous pyrite, and was also identified in a piece of vein quartz containing cyanite. Tourmaline was not noted in any of the veins containing much feldspar, and seems to be most plentiful in certain bold outcrops of white quartz, which show little evidence of mineralization and contain onily triaces of gold.

Cyanite was identified in only one of the gold-bearing veins (see pp. 128129), but was found in several quartz veins not known to contain gold. It was found in metamorphosed wall rock close to veins under conditions that indicate its origin was due to vein action.

\section{Description of the Ore Minerals.}

Gold occurs chiefly in quartz and mechanically enclosed in pyrite, always so far as known in the native state. In the oxidized ores it is frequently found in cavities associated with limonite. It was seen in small scales, grains, and irregular wire-like masses ranging up to $3 \mathrm{~mm}$. in length, and much larger particles have been reported from some veins. No evidence of crystal form could be distinguished. Gold was found in feldspar and in kaolin derived from feldspar. At the Young American mine the presence of chalcopyrite in the ore is considered a favorable indication. Gold was identified in association with tetradymite at the Young American mine, and at the Tellurium mine it is said to occur interfoliated with that mineral. At the former mine gold was found resting on tourmaline. 
Silver is usually present in traces, probably alloyed with the gold. It is said to be abundant in some of the ore at the London and Virginia mine, and argentiferous galena has been reported at the Page mine.

Pyrite is the most abundant of the ore minerals and usually carries gold values. In veins belonging to the Gold Hill system it occurs in large cubes, $1 \mathrm{~cm}$. or more in diameter, but elsewhere it is fine-grained. Cubes are the commonest crystal form, pyritohedrons are also present, and octahedral faces may occasionally be identified. The pyrite rarely constitutes any considerable proportion of the quartz veins, and where it is unusually abundant the gold content is apt to be higher. Occurring as a replacement mineral in the schists and quartzite it sometimes forms 90 per cent. or more of the rock mass. At the Moss mine it occurs associated with tourmaline. Limonite is the common alteration product, and in places magnetite is associated with the pyrite in such way as to suggest its possible formation through partial oxidation of the sulphide. Unstained quartz from the Gold Hill veins frequently contains large cubical cavities from which pyrite has been wholly or partly removed. This phenomenon may be due to solution by ferric solutions or sulphuric acid instead of direct oxidation. Secondary sulphides occur along joint planes in some of the lowest workings.

Pyrrhotite is not' common and occurs chiefly in altered wall rock close to the veins. Chalcopyrite is the most abundant sulphide after pyrite, but is not an important constituent except in the replacement deposits, and there it is largely secondary, occurring chiefly in zones of enrichment near water level. Chalcocite has been identified only in replacement deposits and is probably all secondary. Galena and sphalerite are both rare.

Tetradymite, a telluride of bismuth, is sparingly present at two of the mines, and the failure to identify it elsewhere is probably due to the lack of sufficient exposures as much as to its rarity. While always occurring in small quantities this mineral has been identified at many gold mines in the eastern gold belt, and seems to be one of the distinctive minerals.

Manganese minerals were not recognized in the unaltered ores below water level, but in the oxidized zone near the surface black stain (probably psilomelane) is common along joint planes and fractures.

\section{Summary.}

A number of the vein-forming minerals are of rare occurrence in goldbearing deposits, and cyanite and soda-lime feldspar have not previously been reported. The character and association of many of the minerals are 
indicative of deep-seated origin, under conditions of great pressure and high temperature. The presence of soda-lime feldspars in gold-quartz veins is of considerable importance because of its bearing on the theories of ore genesis. The occurrence of these feldspars as primary constituents in rocks has been considered the strongest evidence of igneous origin.

\section{GENESIS OF THE DEPOSITS.}

In presenting the data contained in the previous sections of this report, it has been assumed that the ores were deposited from aqueous solutions. This theory of vein formation is so well established that it is unnecessary to discuss it here. From facts which were developed in the detailed descriptions and which will later be assembled for further consideration, it is believed that the solutions were magmatic in origin.

The theory of a magmatic origin for gold-quartz veins has been developed within the last 15 years by Vogt, Spurr, Kemp, and others. The formation of this class of veins is closely related to the formation of pegmatites-a question which has interested geologists for nearly a hundred years. It would be out of place in a report of this kind to enter into a detailed discussion of the voluminous literature bearing on the subject, but, for a proper understanding of the argument which follows, it is necessary to outline the theory of magmatic differentiation in so far as it applies to vein formation.

The microscope has shown that in granites and similar rocks, the order of mineral crystallization is hot that of relative fusibility; and synthetical experiments have proven that certain minerals always present in granites, can not be formed by dry fusion without the aid of water or other mineralizers. These minerals are more abundant and better developed in pegmatites-rocks which accompany and in places pass by gradation into the large granite masses with which they' are 'commonly associated. Not only has it been found that every intermediate gradation exists between granite and pegmatite, but that pegmatites, by decrease of feldspar; pass into quartz veins, apparently similar to those which are known to be deposited from circulating solutions. The microscopic study of granites in thin sections, together with chemical analyses, proves that the mineral constituents-especially quartz, the last to crystallize-contain inclusions of primary water which was imprisoned in the solidifying rock. It is believed that the original magmas, from which granites are formed, contain water and other gases, and that as crystallization progresses these are gradually concentrated in a residuum. Pegmatites, and later quartz veins; 
are formed from this residunl magma as it, through partial crystallization, becomes richer in water and relatively poorer in the minerals which are of early formation. In this process of differentiation it is impossible to draw sharp lines for, as Spurr states, "At one end of the series the true granites are not wholly igneous, and at the other end the quartz veins are not wholly aqueous. The processes which formed them all are nearer together than these terms signify." "a

The veins considered in the present report appear to be farther removed from the aqueous end of the series, and more closely allied to pegmatites than any gold-bearing veins which have previously been described. The first part of this chapter dealt with the mineral constituents of the oredeposits, the succeeding sections will be devoted to the nature of the veinforming solutions, their source, the conditions governing ore-deposition, and the origin of the spaces occupied by the veins.

\section{Nature of the Solutions.}

The best information as to the nature of the ore-forming solutions is furnished by a consideration of the primary minerals in the veins and the character of the changes that have taken place in the wall rock, but the absence of a sufficient number of analyses of the vein material and of the country rock, make anything other than a general discussion of the subject impossible.

Microscopic examination of the vein quartz shows that it contains numerous gas- and liquid-filled cavities, and while analyses of these fluids are not available, their composition may be inferred from that of similar inclusions in granitic quartz which have frequently been analyzed. Such inclusions have been found to consist chiefly of water containing alkaline salts and carbon dioxide. Experiments have proved that silica, gold, and the sulphides of arsenic, antimony, iron, copper,' lead, and zinc, are soluble in waters containing carbonates and sulphides of the alkalies, and their. solubility is probably much greater under the conditions of high temperature and pressure which obtained in the ore-depositing solutions.

The solutions must have carried large amounts of silica, and the production of feldspars and mica indicates that aluminum, sodium, calcium, and potassium were present in about the order named. The sulphides of iron, copper, zinc, and lead are all primary minerals, and were therefore essential constituents of the ore-forming solutions. Gold was also present

aSpurr, J. E., Ore Deposits of the Silver Peak Quadrangle, Nevada, Prof. Paper, U. S. Geol. Survey, No. 55, 1906; p. 131. 
and at least some of the solutions contained bismuth and tellurium. While carbonates were noted in only a few of the veins, carbon dioxide was probably a constant constituent. The mineral tourmaline; which is of rare occurrence in gold-bearing veins, contains boron, and some geologists have attributed to this element unusual properties as a mineralizing agent. Fluorine has been found necessary for the artificial production of mica, and Spurr has suggested that the alteration, near mineral veins, of orthoclase to muscovite or sericite, is due to the presence of fluorine in the mineralizing waters. ${ }^{a}$ The absence of orthoclase from the veins in which feldspars were identified, although a little potash mica is of common occurrence, indicates the possibility of some such action, but no fluorite, apatite, or other fluorine-bearing mineral was noted in any of the ore-
deposits.

The question of the degree of concentration which obtained in the oreforming solutions is an interesting one, but until more experimental work has been done on the synthesis of vein minerals under varying conditions, it must, for the most part, remain unanswered. It is probable that under the unusually high pressures and temperatures, which are believed to have prevailed during ore-deposition, the concentration was relatively highhow high is not known.

The presence of much soda-lime feldspar in some of the veins, and occasionally of the-minerals, tourmaline and cyanite, point to unusual conditions in the formation of gold deposits. 'The character and association of these minerals, together with the extensive alteration of the wall rocks, are indicative of a deep-seated origin under conditions of high temperature and great pressure. The metamorphism of the wall rock in many places is similar to that produced by igneous intrusions, and is accompanied by the production of such typical contact minerals as garnet, hornblende, biotite, sericite, tremolite, and cyanite. . In view of these facts it seems unquestionable that the temperature and pressure must have been much higher than those which usually prevail during the formation of gold veins. With the present knowledge of the subject any estimate of the probable temperature and pressure of vein-forming solutions must necessarily be rough, but an attempt may be of value and serve to bring out additional data bearing on the question.

Wright and Larsen, as a result of their investigations, reached the conclusion that vein and geode quartzes and coarse-grained siliceous pegmaaSpurr, J, E,, Geology of the Tonopah Mining District, Nevada, Prof. Paper,
U. S. Geol. Survey, No. 42, 1905, p. 231. 
tites were formed below $575^{\circ}$ C., while graphic pegmatites, granites, and porphyries were in all probability crystallized above $575^{\circ}{ }^{a}$ If the same relation holds in regard to the gold veins described in this report, they must have been deposited at temperatures below $575^{\circ}$. C., and from the metamorphic effects on the wall rocks and the character of some of the vein minerals, it is believed that the temperature of the vein-forming solutions was probably above the critical temperature of water, which is about $365^{\circ}$.

Becker, Graton, Lindgren, and others have recognized that the southern gold veins originally extended far above their present outcrops and it has been estimated that a depth of possibly 15,000 or 20,000 feet may have been removed by erosion. ${ }^{b}$. Taking the average specific gravity as 2.7 , the rock pressures at these depths would be, respectively, 17,550 and 23,400 pounds per square inch. From facts which will be considered in detail in discussing the origin of the spaces occupied by the veins, the writer believes that the veins were formed in the zone of fracture and flowage as defined by Van Hise. There is evidence that, at the time of vein formation, hard quartzites were deformed chiefly by fracturing, while the softer rocks with which they are interbedded, adjusted themselves to unequal strain by flowing. The schists exposed at the Tellurium mine are the weakest rocks found enclosing, veins, and their crushing strength is probably greater than that of good routing slates, for they have undergone greater recrystallization. The crushing strength of strong slates averages from 15,000 to over 30,000 pounds per square inch. While the figures given above are only roughly approximate they serve to indicate the great pressures which prevailed during the formation of the veins. For the rocks under consideration the higher figure is probably more nearly correct.

\section{Source of the Material.}

The composition of the gold-bearing veins is independent of the character of the wall rock, which varies greatly in different localities; and therefore it is improbable that the vein material could have been derived from the enclosing formations. On the other hand, the composition and texture of some of the veins closely resemble that of pegmatites, and it is difficult, if not impossible, to account for the presence and association of such minerals as tourmaline, magnetite, ilmenite, and much soda-lime feldspar, on any hypothesis other than that of magmatic origin.

aWright, F. E., and Larsen, E. S., Quartz as a Geologic Thermometer, Amer Jour. Sci., 1907, vol. xxvii, pp. 446-47.

bLindgren, W., Notes on the Dahlonega Mines, U. S. Geol. Survey, Bull. 203,
, p. 124. 1006, p. 124. 
Additional evidence in favor of this hypothesis is furnislied by the alteration of the wall rock, an alteration which in places resembles on a small scale the contact metnmorphism produced elsewhere in the area by the intrusion of granite into older sedimentaries. The great depth at which the veins were formed and the conditions of high temperature and pressure which must have prevailed, have already been discussed. It is obvious that the solutions from which the ore-bodies crystallized must have originated at points of even higher pressure and higher temperature; for in moving upward the pressure would decrease, and some heat be expended in raising the temperature of the surrounding rocks. These conditions would be fulfilled if we assume the presence of an underlying mass of igneous rock, and this conclusion was reached by an entirely independent line of reasoning (see pp. 102-103).

An examination of the geological maps (Pls. I and II) shows that most of the gold-bearing veins are distributed in belts that roughly parallel the known contacts between intrusive granite and older sedimentaries. In the chapter on structure and metamorphism evidence was presented in support of the hypothesis that the veins are located chiefly along the limbs of anticlinal folds, and that the underlying granite extends highest in the crests of these folds.

Anothers line of argument helping to prove a connection between the reins and granite is furnished by evidence bearing on their relative ageevidence which indicates that the formation of the veins marked the close of the period of granite intrusion and that they were not improbably contemporaneous in origin with the pegmatites and other residual differentiates.

If the solutions that deposited the ore-bodies were derived by differentiation from the original granite magma, the granite itself would be expected to contain some gold, although the quantity might be so extremely small as to make its detection difficult and its quantitative determination impossible. Two samples of granite were tested in order to ascertain, if possible, the presence of any gold. One of these samples consisted of gneissic granite from the quarry at Columbia, and upon assaying it gave negative results. The other was obtained from an outcrop of weathered granite on the farm of H. Williams, one mile northeast of Rivanna Mills. After removing several inches of the partly decomposed rock in order to insure against possible contamination, an average sample was taken over an area of several square feet, and this was quartered down to give a final sample of about 5 pounds. A careful assay of this yielded 0.015 ounce of gold per ton, equivalent to about $\$ 0.31 .^{a}$

a'These two assays were made by E. E. Burlingame \& Co., Denver, Colorado. 
In prospecting for gold, a 15 -foot shaft was sunk on a pegmatite dike, located about 400 yards north of the granite outcrop described above. The pegmatite is partly fine-grained, but contains large angular masses of quartz showing a little pyrite (see sketch, p. 74). Mr. Williams states that some of this quartz assayed nearly $\$ 3.00$ gold per ton.

The results given above prove that the granite does carry gold in places, and while it would be rash to draw conclusions without taking a large number of samples, it is interesting to note that the granite in which gold was identified, is the porphyritic variety showing only slight schistosity, and that it is located near the crest of the hypothetical anticline (see pp. $98-99$ ), at a point where the granite is believed to have been formerly covered by schists at no great distance above the present surface.

\section{Deposition of the Ores.}

The manner in which ores are deposited and the causes which bring about precipitation are of the utmost importance in any consideration of their genesis, but exact knowledge on this subject is as yet very limited. In this district, the inaccessibility of most of the underground workings, which confined the detailed examination of ore-bodies to a very few localities, and the lack of a sufficient number of analyses, necessitates that the discussion of this subject be extremely limited.

The precipitation of ores from solution may be brought about by any one of the following causes, or by two or more of them acting together:

(1) Change in temperature.

(2) Change in pressure.

(3) Change in chemical composition due to

(a) loss of some substance from the solution;

(b) mixture with other solutions; :

(c) reaction between the wall rock and solution.

It has been shown that the temperature and pressure of the ore-bearing solutions must have been higher at the points of origin than they were where deposition took place. Decrease in temperature was probably the chief cause in bringing about the separation of the gangue minerals, and possibly of the ore minerals as well. The effect of changes in pressure is not so well known, but certainly in the case of quartz, decrease in pressure is an important factor in causing supersaturation. The separation of some of the gangue minerals may have altered the composition of the solutions to such an extent that other minerals were thrown down. It is doubtful 
whether the solutions mingled to any extent with other solutions differing in chemical composition, for meteoric waters could hardly be abundant at a depth where the pressure was sufficient to prevent the formation of appreciable openings.

Reaction between solutions and wall rock seems to have been an extremely variable factor in the deposition of the ores, and while these variations may in part be explained by differences in the character of the wall rock, many things indicate that there was probably considerable difference in the composition of the ore-forming solutions in different parts of the district. North of James River there is little evidence of important changes in the chemical composition of the wall rock. In places there has been considerable metamorphism, resulting in recrystallization and the formation of new minerals, but the changes in chemical composition are comparatively slight, and are chiefly due to silicification. Sulphides have replaced some of the minerals in the wall rocks but usually to a very limited extent.

In some of the ore-deposits south of the river, such as the London and Virginia vein, chemical interchange between the solutions and wall rock has been of the utmost importance. Porous rocks are of course most readily penetrated by solutions, and this may help to explain the occurrence of the replacement deposits in quartzites and quartz schists. In these deposits the chief replacement mineral is pyrite. The iron-bearing minerals in the country rock seem to have been attacked first, but in places practically all of the quartz has been replaced. Feldspars, if present, were altered to sericite, and this mineral is about the only gangue mineral left in some of the ores that are most concentrated.

While nothing definite is known concerning the rate of ore deposition, the formation of the deposits was probably exceedingly slow and extended over a considerable period of time. This is indicated by facts connected with the probable manner in which the spaces occupied by the veins were formed-a question which is considered in detail in the following section.

\section{Origin of the Spaces Ocoupied by the Veins.}

Formerly it was generally believed that all true veins were deposited by aqueous solutions circulating through preëxisting fissures. That some veins were formed in such openings is indicated by the presence of symmetrical banding, comb structure, and similar evidence, but in recent years doubts have arisen as to whether all veins could have been formed in this manner. The theory of replacement is applicable in many cases but 
does not furnish a satisfactory explanation of the origin of veins which are accompanied by little or no replacement of the wall rock.

As early as 1898, Russell, in describing certain "brecciated veins," stated that the separation of the rock fragments "seems to be due in part, at least, to the crystallizing of the quartz and calcite." He suggests "that these minerals, in crystallizing, have exerted a force analogous to the expansion of water on freezing, which has crowded the rock fragments asunder." $a$

The fact that growing crystals exert a linear pressure in the direction in which they grow, was noted by Jean Lavalle in $1853,{ }^{b}$ but no quantitative experiments seem to have been attempted until Becker and Day began their investigations. In 1905 , Becker and Day, as a result of their experiments, stated: "It was at once evident that it [the linear force of growing crystals] amounted to many pounds per square inch, and as observations multiplied, it became reasonably certain that it is actually of the same order of magnitude as the ascertained resistance which the crystals offered to crushing stresses." 0 In conclusion they called attention to the geological importance of the force of crystallization and pointed out the possibility of its action in widening quartz veins.

Graton, in studying the gold-quartz veins in North and South Carolina, reached the conclusion "that the solutions, pushing their way along what may in many cases have been the merest fractures, actually forced the walls apart and made receptacles in which their load was deposited."d

Lindgren, advocating the explanation advanced by Graton as opposed to the hypothesis that veins could be formed through the force of crystallization, states that "it scarcely seems possible to attribute such power to it as would be necessary to force deep-seated crevices apart to form room for the crystals, and another strong objection is that it would seem impossible that under these conditions comb structure and coarsely evengrained quartz could be produced."e

The study of veins in the Virginia area, and especially of those exposed at the Tellurium mine, has convinced the writer that the force

aRussell, I. C., A Preliminary Paper on the Geology of the Cascade Mountains in Northern Washington, 20th Ann. Rept. U. S. Geol. Survey, 1808-99, pt. ii, p. 207. bCompt. Rend., 1853, vol, xxxvi, p. 403.

CBecker, G. F., and Day, A. I., The Linear Force of Growing Crystals, Proc Washington Academy of Sciences, 1905, vol. vii, pp. 286-287.

dGraton, L. C., Reconnaissance of Some. Gold and Tin Deposits of the Southern Appalachinns, U. S. Geol. Survey, Bull. 203, 1906, p. 60.

eLindgren, $W$., The Relation of Ore-Deposition to Physical Conditions, Economic Geology, 1007, vol. ii, p. 107. 
exerted by growing crystals must have been the chief factor in the formation and enlargement of these gold-bearing veins. A discussion of the facts on which this conclusion is based, is given below.

The "Middle" vein at the Tellurium mine consists of a series of lenses, varying in size, but remarkably symmetrical in form (see figs. 13-15), Horizontal sections through these lenses resemble the vertical sections in every way. The wall rock is a fine-grained, highly foliated schist containing scattered crystals of garnet, and closely approaches a slate in perfection of cleavage and fineness of texture. The schistosity is parallel to the bedding and older than the formation of the vein, which is conformable in strike and dip. Thirty feet northwest of the "Middle" vein the schist is interbedded with a layer of quartzite about 6 feet thick, known as the "Big Sandstone" vein. This quartzite is also slightly schistose parallel to the bedding. It encloses veinlets similar in composition and texture to the "Middle" vein and evidently formed at the same time and in the same manner, but these veinlets frequently cut across the schistosity of the enclosing rock (see fig. 12). A detailed description of these veinlets and of the "Middle" vein, together with a petrographic description of the wall rocks, is given on pages 157 to 170 .

The fact that the veins of this district show practically no crushing or other evidence of deformation, although the surrounding country rock is intensely foliated, is sufficient proof of their formation since the crustal movements that produced the schistosity, and moreover in some of the harder rocks they occasionally cut directly across the prevailing schistosity.

The space occupied by lenticular veins is sometimes accounted for on the supposition that displacement has occurred along an irregular fault, but in the case of veins like the "Middle" vein, this explanation would be improbable, in view of the symmetrical shape of the lenses, which is the rule even where adjoining lenses differ greatly' in size. This argument is confirmed by the fact that the folia of the enclosing schist, where in contact with the vein, conform absolutely to the curvature of the lenses. It may also be mentioned that single detached lenses are occasionally present near some of the veins (see Pl. X, fig. 2) and such occurrences can not be explained by any method of faulting. In passing away from the lenses the flexures in the schist gradually straighten, so that at a distance of about 2 feet the cleavage is straight and uniform.

From the facts stated above, it is conclucled that the "Middle" vein could not have been formed in a preëxisting fissure, and since the contacts with the wall rock are sharp and without evidence of replacement, the 
lenticular spaces must be due to pressure. That the rock pressure during vein-formation was greater than the crushing strength of the schist, is proved by the uniform curves of the folia-the schists have made room for the lenses by flowing and not by fracturing. The faint line connecting the lenses shows that the ore-bearing solutions, following the lines of least resistance, entered along the planes of bedding and cleavage; but great pressure was necessary to expand such microscopic openings into lenses 2 or 3 feet in thickness. How could such a pressure be developed?

There are two hypotheses that may be advanced to account for the existence of such pressure: (1) The ore-bearing solutions were forced in from below under sufficient pressure to push the walls apart, and (2) the pressure was exerted by the crystallization and growth of the vein-forming minerals.

The chief argument against the first hypothesis is the symmetrical and, in places, almost spherical shape of the lenses. If the expansion of the openings was due to fluid pressure exerted by the ore-bearing solutions, the pressure would necessarily have been equal at all points of contact between the fluid and the walls, except for the slight variations due to friction and difference in elevation. The enclosing schists are apparently uniform in texture and composition, and therefore would offer uniform resistance to the fluid pressure at all points, except those lying in the plane of clenvage along which the solutions entered. Under these conditions very flat lenticular- or tabular-shaped openings must have been formed. In explaining, by means of this hypothesis, the formation of a series of openings. similar to the lenses shown in figs. 13 and 15 , it would be necessary to. assume the presence of areas of unusual weakness at evcry point where an enlargement of the vein occurred. Moreover, since most of these enlargements are symmetrical, it would be necessary to assume that, at these points, there were similar areas of weakness on both sides of the cleavage. plane. Such assumptions are almost inconceivable.

Unless the spaces were filled by ore-deposition as soon as formed, the fluid pressure would have to be uniformly maintained in order to prevent. the walls from collapsing. The great fluidity of the solutions is indicated by the microscopic size of some of the openings along which they entered. Additional evidence against the formation of the openings by fluid pressure. is furnished by the existence of large lenses, consisting of a number of smaller quartz lenses separated by feldspar and layers of schist. (See. fig. 14.)

In a previous paragraph it was mentioned that the veinlets occurring in the bed of quartzite frequently cut across the schistosity. This is ex- 
plained by the greater rigidity and more nearly massive texture of the quartzite which caused it to rupture under the forces of deformation while the weaker schist yielded by flowing. In other words, the rigidity of the quartzite under the conditions of vein-formation was probably greater than the rock pressure, while that of the schist was less. The line of least resistance for the ore-bearing solutions which entered the quartzite was frequently along minute fractures instead of along the poorly developed cleavage planes, and therefore the veinlets do not always conform to the structure of the enclosing rock. If the spaces occupied by the veins are due to fluid pressure, it is difficult to understand why veins a foot or more in width were formed in the quartzite, when the less rigid schist was present on either side. Under these conditions veins might be expected along the contact between the quartzite and schist, or wholly within the schist, but not in the quartzite.

In view of all of the facts outlined above, it seems very improbable, if not impossible, that the vein spaces could have been produced by fluid pressure and then filled by ore-deposition.

According to the second hypothesis, the solutions entered along narrow openings-probably capillary or subcapillary in size-and while under pressure, the pressure was insufficient to expand the openings. Crystallization began at favorable points, possibly about grains of quartz, and as the crystals grew, the walls were locally pushed aside. At first a growing lens may have consisted of a single crystal, but as the folia began to separate, others would form in the space created immediately around the original crystal, where the pressure was lowered by its supporting effect. Since the resisting pressure was equal on opposite sides of the cleavage plane the growth would be symmetrical with reference to that plane. When once started a lens would continue to grow as long as the material for growth was available.

There are many points of similarity between the formation of these lenses and the growth of chert concretions in limestones, or of garnets and similar pseudophenocrysts in fine-grained schists. The localization of growth is probably due to the physico-chemical law by which solutions become supersaturated with respect to large crystals, while at the same time they may exert a solvent action on small crystals of the same substance.

When individual crystals are enlarged their shape is controlled by the tendency to form crystal faces, by the external forces resisting growth, and by the accessibility of the material from which they are composed. When 
masses, consisting of numerous crystals, are enlarged by crystal growth, the resulting shape is controlled chiefly by the forces resisting expansion. The schist enclosing the lenses described above has a much greater tensile strength parallel to the schistosity than across it, and the folia offer considerable resistance to rupture, even when the rock is under sufficient pressure to make it more or less plastic. The resistance offered by these folia to the enlargement of the ore-bodies is somewhat analogous to surface tension, which in liquids causes the assumption of shapes giving a maxi-

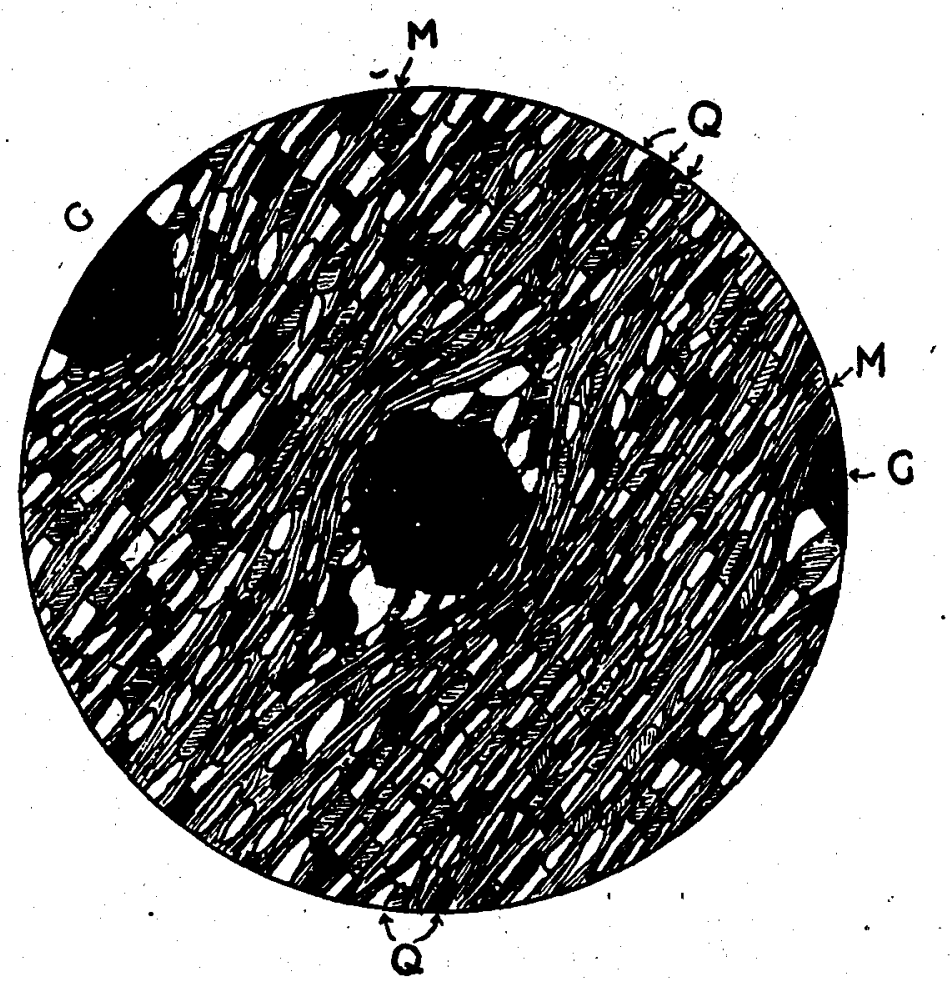

Fig. 21.-Sketch showing recrystallization of quartz about garnets which are of later origin than the foliation of the schist. Thin section cut at right angle to cleavage. With analyzer. $Q$, quartz; $\mathbb{M}$, mica; $G$, garnet. Enlarged about 20 diameters.

mum volume for a minimum exposure of surface. The solubility of quartz decreases with decrease in pressure and supersaturation is reached first where the pressure is lowest. If the resistance to growth were equal in all directions spherical bodies would be formed instead of lenses; and under any given condition the shape produced is that shape which requires the least expenditure of energy. 
The fact that difference in pressure may be an important factor in determining the location of crystal growth, is strikingly illustrated by the recrystallization of qunrtz around the garnets occurring as pseudophenocrysts in the knotted schists of the area. These schists form the wall rock of the "Middle" vein, and it should be noted that where this variety of garnet schist has been found elsewhere in the area, it occurs only in the immediate vicinity of granite contacts. 'The garnets are of later origin

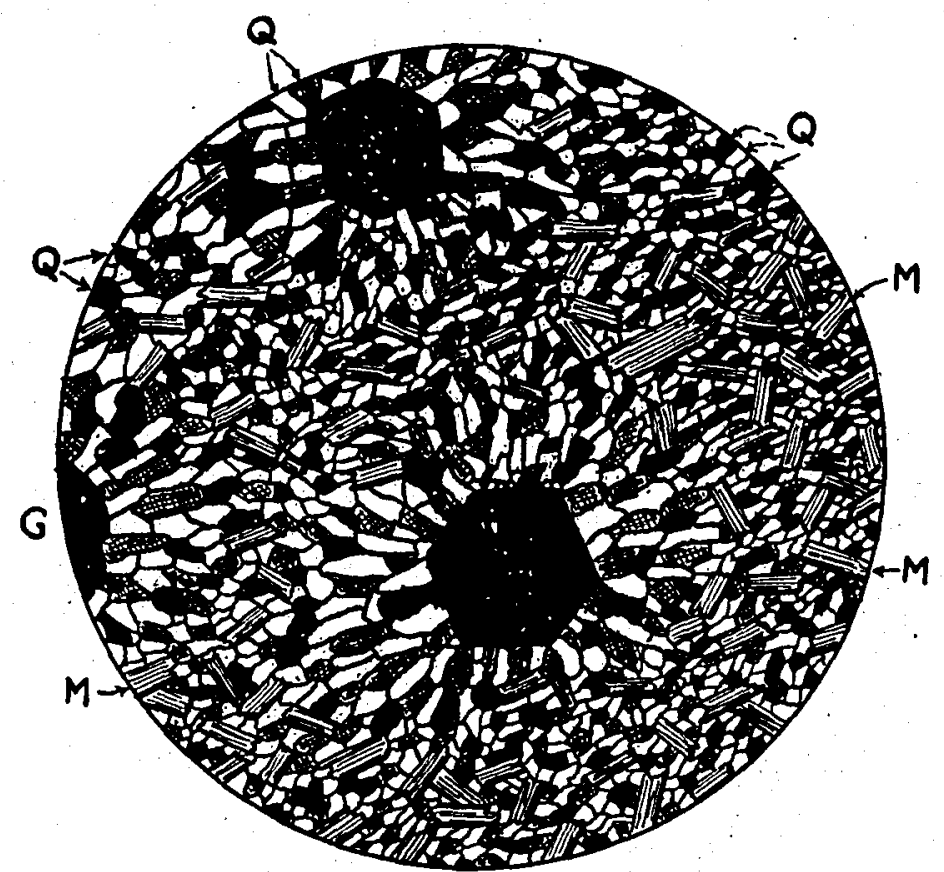

Fig. 22.-Sketch showing radial arrangement of quartz in garnetiferous schist. Thin section cut parallel to cleavage. With analyzer. $Q$, quartz; $M$, mica; $G$, garnet. Enlarged about 15 diameters.

than the schistosity of the rock, and it is believed that their formation in the schist at the Tellurium mine, is due to the close proximity. of granite rather than the metamorphic action of the vein-forming solutions. In either case their origin must have been practically contemporaneous with the formation of the veins. Under the microscope the schists are seen to consist essentially of elongated quartz grains and small flakes of mica, the two minerals being interleaved to form thin layers or imperfect alternating bands. The garnets in their growth have pushed the folia aside, 
and opposite the points of greatest pressure the mica bands run closer together, while the quartz removed from these points has recrystallized between the folia and close to the garnets where the pressure was least. (See fig. 21.) The transfer of the material was undoubtedly due to the small amount of water present in the rock; solution occurred where the pressure was greatest and deposition where it was least. In recrystallizing the quartz grains were roughly oriented so that their greater elongation points toward and away from the garnets. (See fig. 22.)

The partial concentration of feldspar near the ends of quartz lenses, and in small separate lenses practically free from quartz; is caused by the selective power which enables a growing crystal to abstract from solutions material like itself; and this may be taken as additional evidence in favor of the second hypothesis.

An examination of the lenticular veins show that in some instances neighboring lenses in expanding have grown into one another so as to form double lenses, and it is not unlikely that other occurrences of this sort have disappeared through continued growth. The large lenses composed of smaller ones, such as the occurrence shown in fig. 14, were probably caused by the circulation of the ore-forming solutions along several adjoining cleavage planes at the same time, thus permitting the simultaneous growth of lenses at a number of points close together. An alternative hypothesis is that the solutions were deflected into new channels after a lens had been formed causing subsequent deposition to take place about other nuclei located between adjacent folia.

In describing the veinlets occurring in the quartzite, reference was made to the absence of the symmetrical lenses which are characteristic of the vein in the schist. This difference in the shape of the ore-bodies is probably chiefly due to the difference in texture and rigidity of the two varieties of wall rock. If crystallization began at separate points along the fractures in the quartzite and exerted a force tending to open spaces, the rigidity of the rock was sufficient to cause the walls to separate for an appreciable distance beyond the points where the pressure was applied. Any openings formed in this way were filled by deposition from the solutions, and therefore the tendency was to form veins without important variations in width. In other words, rigidity of the wall rock under the conditions of ore-deposition is an essential factor in the formation of veins having a uniform width. This is another illustration of the law controlling the growth of bodies by crystallization, in opposition to outside forces.

The composition of the quartzite has probably aided in producing uniformity in the growth of the veins which it encloses, and this may have 
been of as much importance as the rigidity. Since the quartzite is composed almost entirely of quartz grains, the walls of the fractures would furnish innumerable nuclei on which the vein quartz could separnte out. In thin sections showing the contact between the quartzite and vein quartz, when examined under the microscope, it may be seen that the quartzite grains along the contact have been enlarged, and that there is therefore a gradation instead of a sharp division in passing from one to the other.

Under the conditions which prevailed during the vein-formation, the gneiss, which forms the wall rock at the Young American mine, appears to have been intermediate in rigidity between the quartzite and knotted schist described above. It was folded and contorted by movements preceding the deposition of the ores, and adjustment took place partly by flowing and partly by minor faulting along fractures and shear zones. The vein-forming solutions entered along these lines of weakness and the enlargement of the openings was brought about by the same causes that operated at the Tellurium. In the gneiss, most of the small quartz masses and some of the larger ones are lenticular in form, but these lenses are flatter and as a rule less symmetrical than those of the "Middle" vein at the Tellurium. They are most plentiful in some of the shear zones. (See fig. 9, p. 130, and Pl. X, fig. 2.)

The hypothesis that vein spaces may be enlarged through the force exerted by growing crystals, furnishes a logical explanation for the presence of numerous detached fragments of the country rock in the veins of some districts. These occurrences have usually been explained on the supposition that the veins were deposited in preëxisting fissures, and that the inclusions represent fragments which have fallen from the walls. That this is sometimes true can not be questioned, though it seems probable that such cases are relatively rare. Where the country rock has been shattered so that numerous small fractures are formed, 'ore-deposition may take place in any number of them at the same time, and as the veinlets grow the individual fragments of country rock are gradually separated. According to this hypothesis of vein-formation there is no essential difference between the cementation of many breccias and the formation of branching or reticulated veins. The processes by which both are formed are exactly the same and differ only in degree.

At the Morrow mine, in Buckingham County, ore-deposition seems to have occurred in a zone of fracturing; in places the ore-body consists of vein matter with minor inclusions from the walls, while elsewhere the ore occurs in reticulated veinlets which ramify in all directions through the 
barren schists that form the country rock. All gradations exist between these two extremes. (See fig. 20, p. 204.) The detached masses of country rock have apparently reached their present positions without noticeable rotation, for as a rule the schistosity of the inclusions is parallel to that of the neighboring walls.

The localization of the veins of this district in or near the more rigid rocks, especially quartzites, is very noticeable, and may indicate that at greater depth where the pressure was necessarily greater the solutions were unable to force their way through the fine-grained and more plastic rocks. The greater porosity of the quartzites may also have been a factor.

\section{General Conclusions as to the Origin of the Gold Deposits.}

The primary gold deposits of this area, while varying somewhat in general character, are all intimately related, and owe their origin to the same cause, namely, the intrusion of granitic rocks into the older sedimentaries. They are of two types-quartz veins and replacement deposits-with intermediate gradations between the two extremes. The ores were deposited from highly siliceous and alkaline solutions which ascended from below under great pressure and high temperature. The solutions were magmatic in origin and residual from the crystallization of the underlying granite. This conclusion is borne out by the grouping of the ore-deposits around granite contacts; by the presence and association in the veins of soda-lime feldspar, tourmaline, magnetite, and ilmenite; by the metamorphism of the wall rocks with the production of such typical contact minerals as garnet, hornblende, biotite, sericite, tremolite, and cyanite; by the presence of gold in the granite and its associated pegmatites; and by the evidence as to the relative age of the granites, pegmatites, and veins. It is believed that the precipitation of the ores was due chiefly to decrease in temperature and pressure, though in the replacement deposits interchange of material between the solutions and country rock was an important and perhaps the principal factor.

The ores were deposited at great depths below the surface where the pressure of the overlying rock was sufficient to prevent the formation of open spaces appreciable in size. The solutions forced their way upward along cleavage planes and, in the more rigid rocks, along minute fractures. When deposition began these spaces were gradually expanded by the force of crystallization. The formation of the replacement deposits was probably due to differences in the ore-bearing solutions, but the character of the country rock may have had a determining influence. 
The veins in this district differ markedly from the typical auriferous quartz veins of California, which many geologists regard as having been formed by magmatic waters derived from cooling granites. The California veins are much later in origin, have been subjected to less erosion, and therefore their present outcrops were much nearer the surface when oredeposition took place. This suggests that many of the distinguishing characteristics of the two types are due to the depth below the surface at which the veins were formed. It is not improbable that at greater depth the California veins more closely resemble the gold deposits described in the present report, and that the upper portions of the Virginia veins, long since removed by erosion, were in many respects similar to the veins which are now being worked for gold in California.

\section{SECONDARY ENRICHMENT.}

The distribution of the gold in the ore-deposits is a question of great economic importance, and it is regretted that so little is known concerning the subject. The lack of sufficient development work at any of the mines, which were accessible when the area was studied by the writer, makes it impossible to reach definite conclusions in regard to secondary. enrichment, and therefore the following discussion is necessarily brief.

The facts gathered indicate that the gold is very irregularly distributed through the veins. There appear to be more or less well-defined pockets or ore shoots of relatively rich ore, but the size and distribution of these is unknown. It is probable that the values vary from point to point in depth as well as along the strike of the veins, and this increases the difficulty of ascertaining the extent to which secondary enrichment has been a factor in determining the present value and distribution of the ores.

It seems unquestionable that the veins were much richer near their outcrops than they are at even a short distance below the surface. The greater production of the mines when they were first worked can not be attributed solely to the fact that the ores were oxidized, and therefore freemilling, for the reports of such reliable observers as Silliman, Ansted, and Henwood, furnish evidence of the unusual richness of the veins when the mines were first opened. Henwood, in describing the Morrow mine, expressed his belief that the gold values decreased in depth (see p. 205), and cited the statistics of production in support of this contention. Ansted, in his report on the same property, mentions that near the surface the gold is indifferently disseminated through the quartz, rotten schists, and enclosing walls, while deeper down it gradually collects together and is found 
chiefly within the quartz bands. This local enrichment of the vein and wall rock near the surface, is probably due chiefly to the mechanical concentration of some of the gold formerly contained in the now eroded portions of the ore-bodies, though it is not unlikely that chemical processes have aided in the concentration. Gold is one of the most insoluble substances found in nature, but the long period during which erosion has been almost at a standstill has given every opportunity for concentration to take place through solution and redeposition. Most of the gold that may have been dissolved in this manner was probably reprecipitated before it had been carried far, for precipitating agents were plentiful.

In some of the deeper openings which extended below the oxidized zone, secondary pyrite is found occurring along joint planes and fractures, but the development work is insufficient to determine whether or not there has been any enrichment of the gold values at this depth.

\section{AGE OF THE ORE-DEPOSITS.}

Geologists have usually assumed that all the primary gold deposits in the Southern Appalachian region belong to the same metallogenetic epoch. While it is not improbable that this is true, it has not, as yet, been established by sufficient detailed geological work. Many of the older geologists considered the-voins contemporaneous with the enclosing rocks which were classified as "primary." Becker and most of the recent workers have placed the deposits in the pre-Cambrian.

The veins in the district covered by the present report, were formed after the intrusion of the granite, and probably represent the final stage in the period of igneous activity which preceded their deposition. They show no evidence of having been subjected to the great crustal movements which so intensely metamorphosed the enclosing sedimentary rocks and even the massive granites. These movements were probably inaugurated and the sedimentaries rendered schistose prior to the intrusion of the granites with which they are in contact. The well-developed schistosity of most of the granitic rocks is evidence that the movements continued throughout the greater part of the period covered by their intrusion. The porphyritic facies of the granite show decreasing pressure effects and many of the pegmatites are practically massive. 'These facts are discussed at greater length in the chapter on structure and metamorphism.

The profound changes to which the ore-bearing formations were subjected prior to the intrusion of the granite, indicate that a considerable time interval must have intervened between the deposition of the sedi- 
ments and the formation of the veins; and this together with the lack of important crushing, or other evidence of disturbance in the quartz veins, suggests that they are later than pre-Cambrian in age.

Subsequent to the intrusion of the granite and the formation of the gold veins, sufficient time elapsed for erosion to remove the overlying material and expose the deep-seated granite, before the surface was again depressed to receive the sediments of late Ordovician time. The Arvonia slates, which are known to be Cincinnatian in age, were laid down on the older schists and in places on granite which is only slightly schistose. Therefore even the granites which were last to solidify are older than Cincinnatian in age. The slight evidence of dynamic metamorphism exhibited by the gold-bearing veins was probably induced by the movements which elevated and folded the Ordovician sediments.

A consideration of the facts outlined above makes it appear reasonably certain that the primary gold deposits in the James River basin are older than Cincinnatian in age, and they are probably younger than preCambrian. Until further evidence is available, the writer is of the opinion that the veins should be classified as Cambrian. 


\section{CHAPTER VII.}

\section{PLACERS.}

Gold has been found in the gravels of all streams that cross the goldbearing rocks of this area, and also in certain ancient stream gravels that are now located high above the neighboring water-courses. Most of these "branch" gravels, as they are locally called, have been worked, and some of them reworked a second time in order to recover the precious metal which they contained. Gold also occurs, concentrated in considerable quantity, in the accumulations of residual decay overlying the gold-bearing veins and in their immediate vicinity, and such deposits have been profitably worked in a number of places.

When the gold-bearing veins and the enclosing country rocks were exposed by denudation to the chemical and mechanical action of the agents of erosion, the slow process of concentrating the heavier and more resistant constituents into the placer deposits began, and this has been in continuous operation ever since. The minerals with least resistance are attacked first, their decomposition, making easier the disintegration of the remainder, and under this process the rocks slowly go to pieces. If the products of weathering collect faster than the streams can transport them, deep residual soils are gradually formed. Of the common minerals, quartz is the hardest, the least soluble, and does not undergo chemical decomposition; and since it is the principal vein-forming mineral, the veins usually extend for some distance above hard rock into the overlying mantle of residual decay, but frost and plant roots step by step brenk up even the larger veins and add their constituents to the soil.

With the breaking down of the rocks and the formation of disintegrated material, the next step in the process of concentration is that of sorting and transportation. Expansion and contraction, due to changes in temperature and to freezing and thawing where water is present, cause the soils to gradually creep down hill. The wash of rain water aids in this slow movement by carrying off the lighter particles, while the heavier fragments lag behind. In this way a partial concentration of the heavier constituents in the residual decay is brought about, and as gold has a very high density and is relatively insoluble, it frequently occurs in considerable quantity in the decomposed material lying vertically above gold-bearing veins, and along the hill slopes immediately below them. The gold found 
in such localities has not traveled far and is therefore comparatively rough and angular, while the quartz and other rock fragments which may accompany it do not show the rounded waterworn surfaces of stream gravel. Deposits of this nature have been worked in a number of places, notably at the Tellurium and Waller mines where they are said to have been very rich.

The slow creep of the soil and occasional heavy rains gradually bring the products of disintegration within reach of running streams, which continue the work of concentration, but here an additional process is brought into play-that of abrasion. The swiftly flowing streams rapidly remove the finer sediments in suspension while the heavier fragments are rolled along more slowly by the current, constantly striking and grinding against one another. This continual impact and friction, in time, is sufficient to wear away the toughest rocks, and quartz while hard is rather brittle. The gold, being malleable, escapes most of this comminution, and because of its high specific gravity settles through the sand and gravel until it finds lodgment close to bedrock. In this manner the placer deposits are gradually formed in the stream beds.

If for any cause the course of a stream is changed, the placer gravels which have been formed in its bed may remain as deposits of dry gravel which, as the stream deepens its channel, are left high above the water level. Placer gravels of this type were at one time extensively worked on the Collins place, a mile northeast of Lantana.

As a result of the hammering which they have undergone, the gold nuggets found in placer deposits are smooth and rounded, differing in this respect from those found closer to the original vein deposits. The placer gold is, moreover, somewhat purer or of a higher degree of fineness than - the vein gold, for during the long time in which it has been subjected to the oxidizing and solvent action of the agents of weathering, impurities have been largely removed. In other words, the gold has passed through a sort of natural refining process as well as one of concentration.

The unusual richness of the branch gravels as compared with the original vein deposits from which they were derived is due to the great length of time in which the process of concentration has been going on, the large amount of material which has been worked over, and the very limited extent of the gold-bearing gravels formed.

The area has probably been subjected to erosion almost continuously since the close of Ordovician times, and this has affected the gold deposits ever since the veins were first exposed by degradation. Everything bearing 
on the genesis of the gold veins, as has been stated in detail elsewhere, indicates that the portions of the veins that are now exposed, were formed at a great depth below the surface; and a study of the physiography of the area gives independent evidence as to the thousands of feet of overlying rock removed by erosion. The veins, when formed, must have extended several thousand feet above the present surface, and while most of the gold originally contained in this vast amount of material was probably carried away and lost, a considerable proportion of the metal, because of its toughness, resistance to ordinary solvents, and high specific gravity, has been retained and concentrated into the relatively small bulk of material composing the placer gravel deposits.

The placer gravels of Virginia are limited to the immediate vicinity of the vein-deposits from which they have been derived, and nowhere do they cover large areas, being almost entirely confined to the branches and smaller creeks. Much of the placer gold is coarse, and this together with its comparative roughness indicates that it has not traveled far. The branches are frequently reported to have been richest near the veins, and none of them was worked for any great distance below the lowest known veins, usually less than a mile. They carried little or no value above the veins, and in fact many of the veins, which seldom outcrop, were located by panning ip the branches. Large deposits of low-grade gravels, such as those in California which were extensively worked at one time by hydraulic methods and are now being worked by dredging, have not been found in Virginia. The only place within the present area where it would be possible to find similar gravels is in the Triassic beds, which are exposed near the southern boundary of the area. It is interesting to note that Becker, working in a similar district, found transported gold in the Newark (Triassic) conglomerates of North Carolina. ${ }^{a}$

During the time in which the present branch gravels were being concentrated, the physiographic conditions in Virginia were not suitable for the formation of low-grade placers. The fact that approximate peneplaination has continued for a long period of time is probably the reason that large deposits of auriferous gravels are absent and that the placer gravels are all concentrated close to the primary deposits. The factors which make the Virginia branches such perfect "concentrators" having been outlined above, it might be of interest, for purposes of comparison, to state briefly the conditions under which the large low-grade deposits of California were formed.

aBecker, Geo. F., Reconnaissance of the Gold Fields of the Southern Appalachians, 16th Ann. Rept., U. S. Geol. Survey, 1894, pt. iii, pp. 315-316. 
In California the mountain streams crossing the gold area are swift, and consequently their powers of transportation high; the rainfall is light, but largely confined to certain seasons of the year when sudden floods are not uncommon. The result of these conditions is to give a maximum of transportation efficiency for a given volume of water, and the streams are able to carry down vast quantities of gravel and even boulders of considerable size. When the streams, however, reach lower elevations and enter the large valleys that stretch back from the coast, their velocity is checked and their power of transportation suddenly diminished, causing them to drop a large part of their-load. In this way gravel deposits, which often cover large areas to a depth of 30 or even 100 feet or more, and which in places contain small quantities of irregularly distributed gold, have been built up in some of the valleys.

The placer gravels were extensively worked during the early days of mining in the James River district, and in many places they are reported to have been very rich. At this late date no authentic records are obtainable that would give the amount of gold produced by the placer deposits of this district, or even of the State as a whole, but it is unquestionable that a very large percentage of the total gold production in Virginia has been derived from the gold-bearing gravels. While most of these branch gravels were worked' out years ago, it is still possible to estimate the extent of the deposits from the irregular piles of gravel that were always left behind.

In this section all known placer deposits that could be profitably worked by the simple methods formerly employed, were long ago exhausted, and it is improbable that new ones will be discovered in the future. In regions, such as this, which have long been inhabited, one can no longer expect to find rich, easily workable placer gravels, and this is especially true in a section where the presence of gold has been known for so many years, and where so much prospecting has been carried on. The presence of gold in such deposits is so easily detected, even by those witl little experience, that there is little likelihood of its being overlooked, and the methods that may be used to recover it are so simple and inexpensive that the deposits are quickly worked out.

Much gold was lost by the wasteful methods commonly employed when the branch gravels were first worked; and it.would probably pay to rework many of these deposits, if a suitable method could be devised for handling them cheaply on a large scale. In the early days of mining the branches were usually leased, and the gravel washed in rockers by tributer's who 
payed a certain percentage of the gross proceeds, as a rule a fifth of the gold recovered. Some gold escaped recovery or was overlooked, and when the gravels were poor or mixed with sufficient clay to make washing difficult they were left untonched. Panning shows considerable gold even in the gravels that have been washed, and these also contain some mercury and amalgam lost by the early miners. Most of this gold is fine but it is granular and easy to recover; the gravel is small in size, contains but little sand and there are no boulders. In most places the grade is not sufficient for sluices.

The only known placer gravels which have not been worked are those that occupy the bed of Byrd Creek and in places underlie the adjacent lowlands, but up to this time the difficulties involved in the profitable handling of these gravels have proved insurmountable. While they have not been systematically prospected, it seems certain that the Byrd Creek placer gravels must contain much gold. Byrd Creek is one of the larger streams of the area, and it cuts directly across the gold belt, while its tributaries include most of the rich branches formerly worked for gold.

So far as known the only effort to work the Byrd Creek gravels was made about the year 1900 . During the summer, while the water was low, an attempt was made just above Bowles' Bridge, 4 miles northeast of Columbia, to turn the creek aside, sink pits down to bedrock in the stream bed, and wash the gravel in rockers, but this experiment proved unsuccessful, for the water could not be kept out and the pits soon caved. It is said that the gravel was about 7 feet deep and that there was no overburden of mud; bedrock looked like slate and was covered with a layer of soft, decomposed rock that made shoveling easy. The gold was coarse, most of it being "about the size of wheat grains." The conditions may have been unusually favorable at this place as a branch that had rich placer gravels entered the creek not far above.

The only other information bearing on the value of the Byrd Creek gravels is furnished by some prospecting done on the Bertha and Edith tract, which lies on the east side of the creek 3 miles northeast of Columbia. All the branch gravels on this place were washed for gold years ago, and the placers along Great Camp and Maple branches are reported to have been very rich. At that time Big Byrd Creek was dammed to furnish power for a mill located near the southern end of the property; and the mill pond thus formed covered about 3 acres including the lower portions of Great Camp and Little Camp branches. The gravels covered by the old mill pond, which has since been drained, have never been worked. In 
1897, a company, which held the property under lease and option, sank a number of prospect pits in the flat near the mouth of Great Camp Branch and started to work the deposits, but all work was discontinued when their nearly completed mill and cyanide plant were destroyed by fire. Where the prospect pits were sunk the gravel was found to be from 1 to $21 / 2$ feet thick and covered with an overburden of from 4 to 7 feet of sandy soil. It is stated that all the gravel carried gold, the values averaging from 1 to 2 pennyweight per square foot. The amount of gold did not seem to vary with the thickness of the gravel and most of it was found close to bedrock. The gold was quite coarse, many of the grains weighing from 0.10 to 0.20 pennyweight, while the largest nugget recovered weighed 1.78 pennyweight.

These facts prove that coarse gold was carried by the branches as far as the creek, and it can hardly be doubted that the gravels of the creek bed contain sufficient gold to make their mining profitable, providing a suitable method of handling them can be devised.

Any successful method of working these placer gravels will have to take into consideration the following facts:

(1) Along much of its course Byrd Creek is bordered by steep banks, which in places give way to high bluffs, and this would make its diversion difficult if not. impracticable.

(2) The mean discharge of the stream is large and it is subject to occasional floods.

(3) There is not sufficient fall in the creek to allow the emplovment of sluices, and the disposal of tailings would be difficult.

(4) While no boulders occur in these gravels, the banks are in many places lined with trees, and their roots would probably interfere with dredging or similar methods of mining.

(5) At several points there are rapids in the creek caused by ledges of resistant rock which outcrop in the bed of the stream. 


\section{CHAPTER VIII.}

\section{DESCRIPTION OF COPPER MINES AND PROSPECTS.}

\section{TYPES OF COPPER DEPOSITS.}

Copper ores have been prospected at three localities in this district and the ore-deposits consist of two distinct types. The Lightfoot mine on the southeast side of Slate River about 2 miles northwest of Arvonia, and the Anaconda mine, located $31 / 2$ miles west of Johnson and 5 miles north of Dillwyn; belong to one type, while the mines near New Canton are opened in a very different kind of ore-deposit.

Ores of the type first mentioned occur as veins or lenticular masses in greenstone schists derived from basic igneous rocks, while ores of the lastnamed type are found impregnating crystalline schists, adjacent to their contact with an intrusive granite (quartz-monzonite with a dioritic border facies). In both types the principal ore-minerals are pyrite, more or less auriferous, and chalcopyrite. The origin of the ores belonging to each type will be discussed after the individual occurrences have been described.

\section{DESCRIPTION OF INDIVIDUAL MINES.}

\section{The Lightfoot Mine.}

Location.-The Lightfoot copper mine is located on the southeast side of Slate River, 2 miles northwest of Arvonia.

History.-The property was first worked for gold (see p. 207), but the copper deposit was opened shortly before the war by a company which is said to have shipped 100 tons of the ore to a smelting house in Baltimore, where it brought $\$ 80$ per ton. ${ }^{a}$ The outbreak of the war in 1861 put a stop to work at the mine, and since that time while there have been some spasmodic attempts to develop the property (the last about 1904) little has come of them. A shaft has been sunk to a depth of 85 feet, the collar of the shaft being about 20 feet above the level of the nearby stream, and several short drives have been opened.

Country rock.-The Lightfoot mine is situated in an area of greenstone schists, which under the microscope are seen to be igneous in origin. The strike of the schistosity is northeast and southwest and the dip is steeply

aHamilton, J. R., The Natural Wealth of Virginia, Harper's Magazine, 1805, vol. xxxii, p. 41 
toward the northwest. The schists show little variation in texture or color, being usually dark green and fine-grained. Megascopically, chlorite and epidote with occasional eyes and stringers of quartz and calcite are the most prominent minerals; and when the powdered rock is tested with a magnet it is found to contain an abundance of fine-grained magnetite. In addition to these minerals, plagioclase feldspars, hornblende and some titanium minerals can usually be recognized under the microscope. These rocks are described in greater detail on pages 49-51. A little pyrite, often more or less cupriferous, and the secondary copper mineral-malachitewere found in the schist at several places within a mile or less of the mine. Where the rocks have been much fractured the openings are filled with quartz, epidote, calcite, or mixtures of these, forming irregular veinlets. In places magnetite appears to have undergone a similar concentration and may be picked up on the surface in pieces the size of hen's eggs or even larger.

Ore-deposit.-According to Credner, the vein was 4 to 5 feet wide near the surface, and consisted of iron oxide; below this capping, iron pyrites was encountered and continued for about 20 feet before chalcopyrite began to appenr; and in the lower workings he found a coarse-grained mixture of iron and copper sulphides, which carried 11 per cent. copper. ${ }^{a}$ The lower workings of the present opening are said to show an irregular vein, which in places consists of roughly parallel veinlets, ranging from several feet in width down to an inch or less, and the walls are rather shiarply defined.

The waste rock found on the dump shows that the country rock in the immediate vicinity of the vein las been greatly crushed and fractured. Extensive epidotization has taken place along the fractures, and where openings had been formed they are usually filled with quartz containing crystals of epidote and sometimes considerable calcite. The veinlets formed in this way are usually 4 or 5 inches in widtli or less. In places vug-like openings occur lined with quartz and crystals of epidote. Pyrite and chalcopyrite are occasionally present in the wall rock as well as in the veinlets, and where these minerals have been long subjected to oxidation the green stain of malachite is usually prominent. All the rock contains more or less magnetite, and fine-grained masses of this mineral, weighing several pounds, were noted, in which the only impurities that could be detected megascopically, were a little quartz, epidote, and occasionally

aCredner, H., Report of Explorations on the Gold Fields of Virginia and North Carolina, Amer. Jour. Mng., 1869, vol, vii, p. 58. 
chalcopyrite. A piece of the greenstone schist found on the dump contained a veinlet or segregated area of white feldspars, which were 0.5 to 1 $\mathrm{cm}$. in diameter, and showed fine albite twinning. Chalcopyrite and magnetite were plentifully distributed between the feldspars, and in places along their cleavage planes, in a way that indicated a later origin for the ore minerals.

The best ore seen at the mine consisted essentially of a mixture of pyrite and chalcopyrite, but most of the ore found on the dump was composed chiefly of pyrite, slightly cupriferous, with a little quartz, chlorite, and epidote visible to the naked eye. Assays of the ore are said to show good values in gold, and Hamilton states that native copper was found in some of the ore, but this could not be confirmed.

\section{The Bumpus Property.}

At several other localities in this vicinity a little prospecting for copper has been carried on. The old Bumpus place lies northwest of the Lightfoot mine on the opposite side of Slate River, and here a 20-foot shaft was sunk at a point where much limonite and magnetite were found on the surface. The shaft was opened in soft chloritic slate, and no copper ore seems to have been found.

\section{The Ford Property.}

On the Ford property, about three-quarters of a mile southwest of the Lightfoot mine, a vein is said to have been discovered in 1835 , which was rich in gold at the surface, but at a depth of 4 or 5 feet copper pyrite became so plentiful as to interfere with amalgamation, and the work was abandoned. ${ }^{a}$ Later, a 60 -foot shaft was sunk to strike the vein at another point, but a few lenticular quartz concretions containing copper pyrite seem to be all that was found. Credner mentions two small veins that were exposed by open cuts, the gangue being quartz, while iron and copper pyrite, and a little free-gold were present. ${ }^{b}$

\section{The Anaconda Mine.}

Location.-The Anaconda mine is located near Eldridge Mill, and is about $3 \frac{1}{2}$ miles west of Johnson and 5 miles north of Dillwyn, stations on the Buckingham Branch of the Chesapeake and Ohio Railway.

History. - The Anaconda mine was formerly known as the Eldridge mine, and about 1903 it was under development by the Q. Q. Copper Co.,

\footnotetext{
aHamilton, J. R., Op. cit.
}

uCredner, H., Op. cit. 
which sank a shaft to a depth of approximately 60 feet. About 1905 the United States Mineral Co. did a little development work, and in 1910 the shaft was again pumped out, but almost immediately allowed to refill with water. The shaft is now said to have a depth of nearly 75 feet, and near the bottom, a short drive extends in a northeast direction. While work

- was going on, 3,300 pounds of ore running 103/4 per cent. copper were shipped to the smelter at Norfolk.

Descriptive geology.-The ore-deposit lies in the same belt of greenstone schists in which the Lightfoot mine is located and the country rocks are, for the most part, similar to those already described. About 400 yards northeast of the mine several openings have been made exposing amphibole asbestos, some of the fiber being 7 or 8 inches in length, talc, and chloritic schists carrying needle-like crystals of actinolite. The rock found on the dump is practically the same as that at the Lightfoot mine. It is mostly a dark green, fine-grained chloritic schist, in which considerable epidote is present especially along fractures. A little calcite in small crystals is in places scattered through the rock mass, but no veinlets or large masses were seen. Fine-grained magnetite and occasional grains of pyrite and chalcopyrite were noted. In a thin section (Spec. 352) the minerals present, in the order of their relative abundance, are quartz, chlorite, epidote and-ziosisite, hornblende, calcite, plagioclase feldspar, pyrite, and titanite. The hornblende occurs in dark green, needle-like prisms largely altered to chlorite. The calcite frequently shows multiple twinning. It is apparently a basic igneous rock which has been extensively altered by pressure and hydrometamorphism.

Specimens of the ore seen at the mine consist essentially of pyrite and chalcopyrite intercrystallized with quartz as gangue. A little bornite, probably secondary, was noted in places, and the carbonates azurite and malachite, derived from the sulphides, are also present, usually along fractures in the rock. The vein is snid to be several feet wide in places, but elsewhere pinches to almost nothing.

\section{Genesis of Ores at the Lightfoot and Anaconda Mines.}

Many basic igneous rocks in different parts of the world have been found to contain small quantities of copper. Rocks of this type are common throughout much of the Blue Ridge region in Maryland and Virginia where there are basaltic lava flows, which, since their extrusion, have been greatly altered, with the production of secondary minerals, especially chlorite and epidote. As a result of the metamorphic changes 
which these rocks have undergone, the small amount of copper originally disseminated in the rock has, in places, been locally concentrated along joints and fractures, giving rise to copper deposits which have become known as the Blue Ridge or Catoctin type. ${ }^{a}$

The ores at the Lightfoot and Anaconda mines are similarly situated in an area of altered basic rocks, igneous in origin; and copper-bearing minerals have been found occurring in the country rock in small quantities at a number of widely separated localities; but there is a marked difference between the ore-deposits in this area and those of the Blue Ridge type, especially in the character of the ore-minerals. In the Blue Ridge type of deposit, the ore-minerals are chiefly cuprite and native copper, the latter often as nucleal masses surrounded by cuprite, together with small amounts of azurite and malachite, and, very rarely, of copper sulphide. ${ }^{b}$ At the Buckingham County mines the copper minerals are chiefly sulphides, malachite and azurite being present only to a limited extent, and where they have been clearly derived from the sulphides, while cuprite and native copper are rare if they occur at all.

Both the Lightfoot and the Anaconda mines were inaccessible when the writer visited the district in 1910, and it would be impossible to make definite statements in regard to the genesis of the ore-deposits without more detailed examination, but it seems probable that the copper, which they contain, Wris originally disseminated through the surrounding rocks, and that it has been concentrated by the circulation of meteoric waters, at favorable points in openings formed by local fracturing. Some of the principal facts in favor of this hypothesis may be summed up as follows:

(1) Copper-bearing minerals are present in small quantities in the country rock at considerable distances from the ore-deposits, and therefore the country rock furnishes a possible if not the probable source of the ore-minerals.

(2) The principal gangue minerals in the ore-deposits-quartz, epidote, calcite, and magnetite-are important constituents of the country rock, the difference being one of relative proportions only, and no minerals have been observed in the ores that have not been found in the country rock. Therefore the country rock furnishes a possible if not the probable source of the gangue minerals.

aWeed, W. H., Types of Copper Deposits in the Southern United States, Trans. Amer. Inst. Min. Eng., 1900, vol. xxx, p. 498.

bWeed, W. H., Copper Deposits of the Appalachian States, U. S. Geol. Survey, Bull. No. 455, p. 14. 
(3) The frncturing of the rocks furnished a clinnnel for the circulation of concentrating solutions and openings for the deposition of the oredeposits.

(4) The extensive formation of lyydrous from anhydrous minemals, which is the chief feature in the metamorphism of the great mass of rocks in this immediate area, necessitates the introduction of much water, and circulating water is an agent sufficient to account for the transportation and concentrintion of the mincrals forming the ore-deposits.

(5) The extensive formation of epidote adjacent to fractures in the immediate vicinity of the ore-deposits is evidence of the circulation of solutions at these points.

The difference between the Buckingham copper deposits and those of the Blue Ridge type may possibly be due to the formation of the former at a greater depth, and to the fact that the greenstone schists in this district are, as a whole, more dense, closer textured and without the amygdaloidal cavities and similar openings common in much of the Catoctin schist. As originally deposited, these ores probably consisted chiefly of cupriferous pyrite, and in that case most of the clialcopyrite owes its origin to secondary enrichment. It is doubtful whether the copper values will continue to any considerable depth from the surface, and the writer does not believe that these deposits will prove to be very extensive or of much cconomic value.

\section{THE NEW CANTON MINES}

'The New Canton ore-body has been exposed by a series of openings, consisting chiefly of shafts and tumnels, which begin at a point half a mile south of New Canton and extend in a straight line for a chistance of a mile in a southwesterly direction. (See map, fig. 2, p. 17.)

HISTORY, ,

While the New Canton mines have never been of much economic importance, they have had a long and varied history, having been first worked for iron, later for copper, and more recently prospected for pyrite. The gossan or oxidized ore, which consists principally of limonite and forms the surface cap of the sulplide bodies, first attricted attention.; and according to Prof. Rogers, iron was manufactured from the Buckingham ore as early as the Revolutionary War. However, very little mining was done until some time in the early 30's, when a charconl furnace, known as the Bear Garden or Denn furnace, was built about half a mile south of New Canton. In his "Report of the Geologicnl Reconnoissance of the 
State of Virginia, 1835," Rogers states that, "the limestone on the western edge of the county furnishes the flux employed in the smelting of this ore, which, under the superintendence of Mr. Dean of New Canton, is now conducted on a scale of such extent as to give a weekly product of between thirty and forty tons of pig metal, much of which is of a superior quality." a Piles of slag indicate that there was another furnace locnted less than a mile southwest of New Canton. Mining was entirely confined to surface cuts along the outcrop, and as these became deeper pyrite began to appear and rapidly increased until the percentage of sulphur became prolibitive. Rogers says that fine specks of gold were discovered in the cinder or slag at these works. Iron ore was also hauled from Ore Bank, three-quarters of a mile southeast of Arvonia, and smelted at the New Canton furnace, but in 1840 the furnace was abandoned and no further work seems to have been done until prospecting for copper was started.

The Johnson Mine.

At the Johnson mine, formerly known as the Staples mine, which is located three-quarters of a mile west of south from New Canton, a 78-foot shaft was sunk by Mr. Staples, who mined and shipped 780 tons of ore averaging 8 per cent. copper. After this the property was leased and operated by White $\&$ Walters for a period of 2 or 3 years, beginning about 1891. Several shipments were made and $\$ 4,000$ is said to have been realized from the copper in the ore. About 1903, the Johnson Mining Co. bought the property and began development work. A vertical slinft, started on top of the hill, was sunk to a depth of 278 feet, and an adit was driven from the creek northwest to connect with the shaft. There are 3 levels in the mine and the total length of the drives is said to be 1,000 feet or more, but little or no mining was doue.

\section{The MoKenna Mine.}

The McKenna mine joins the Tohnson mine on the northeast, and is situated a little over half a mile south of New Canton. It was first prospected for copper by J. P. McKenna about 1895, and in 1906 the Virginia Copper Co. began to develop the property. A 53-foot shaft was sunk at the foot of the hill in the lowlands near the creek, and two short drives opened from it, but work was stopped in 1907, and has not been resumed since that time.

a Rogers, W. B., Geology of the Virginias, p. 80. 


\section{The Hudgins Mine.}

The Hudgins mine, located 1.5 miles sonthrest of New Canton, was opened about the same time that the other two mines were being prospected. A shaft was sunk to a depth of about 70 feet, which seems to have been the extent of the development work. When visited by the writer in 1911 the shaft had partly caved and was inaccessible.

\section{The Margaret Mine.}

The Margaret or Terrell mine adjoins the McKenna mine and is situated on the west side of Phelps Creek about half a mile south of New Canton. This property was first opened in April of 1910, when a shaft was sunk to a depth of 80 or 90 feet in search of a pyrite deposit that could be profitably worked. When examined by the writer in the summer of 1911 the shaft had been pumped out, and preparations were being made to sink it deeper.

\section{GENERAL DESCRIPTION OF THE GEOLOGY.}

The bluffs along James River and Phelps Creek furnish an almost perfect section across the rock strata in which the New Canton mines are situated, and this section, together with the mine openings and occasional outcrops-elsewhere in the vicinity, make it possible to study these oredeposits in somewhat greater detail than can be done in the case of most of the reins that occur in this area.

The New Canton sulphide deposits occur in a schist, sedimentary in origin, which; a few hundred yards west of the mines, is interbedded with a schistose quartzite. East of the mines, stretches the area of intrusive granite (chiefly granodiorite), but between the granite and the oredeposits is a belt of hornblendic schists 700 to 900 yards wide, part of which represents a basic border facies of the granite, while the rest is probably sedimentary in origin, though intensely metamorphosed. by the intrusion of the great igneous magma. It is not possible to draw with certainty a line between the hornblende schists that are igneous, and those that are chiefly sedimentary in origin, for the former as well as the latter have been greatly changed by metamorphism under mass-mechanical conditions; and the difficulty is increased by the fact that there are dikes or apophyses from the igneous mass, interleaved with metamorphic rocks which are apparently sedimentary in origin. The series of rocks encountered in passing across this contact is described in detail on pages $107-112$, and therefore they will be discussed here only in so far as it is necessary to bring out their relations to the ore-deposits. 
Northeast of the mines, at a distance of 300 to 400 yards, the country rock is a dark gray knotted slate, or schist, containing numerous rounded pseudophenocrysts of biotite averaging 1 to $1.5 \mathrm{~mm}$. in diameter. These crystals of biotite are dark brown to black in color and have no regular orientation relative to the schistosity of the fine-grained slaty ground-mass in which they are embedded. Small reddish-brown garnets may also be present but are not plentiful. In the ground-mass quartz, sericite, and a few scattered grains of magnetite, are the only minerals distinguishable megascopically, but under the microscope biotite, chlorite, and rarely plagioclase feldspar, may also be identified.

Passing eastward toward the contact, the biotite crystals gradually give place to garnets, and at the same time the schists become slightly coarser grained and lighter in color. The difference in color may be due to difference in composition, but is probably, in part, caused by increased development of sericite and a greater concentration of the iron in certain iron-bearing minerals. Small crystals of pyrite are abundant in the schists near the ore-bodies, which have no definite walls or boundaries. The ore is found in white to light gray, garnetiferous schists which, aside from the impregnating pyrite, are composed essentially of sericite and quartz, though chlorite is usually present and sometimes in considerable quantity. Plagioclase feldspar occurs to a limited extent, and occasional crystals of hornblende begin to make their appearance.

The ore-minerals, chiefly pyrite, occur irregularly disseminated through the quartz-sericite schist, and where most abundant form irregular stringers or lenses parallel to the schistosity. The mineralized schists are cut by occasional small lenticular veins of quartz, carrying more or less feldspar, but as a rule they contain little pyrite, though the latter, in places, is concentrated along the walls of the veins.

The hornblende schists on the east side of the ore-bodies are usually fine-grained but vary somewhat in composition and texture in passing. across their strike. In the vicinity of the ore-deposits, and for some distance along their line of strike where they have not been found, there is usually much pyrite in the hornblende schists. Within 100 or 150 yards of the ore-bearing schists, apophyses of the granite occur as intrusions in the hornblendic rocks, and, at least in places, there is a narrow band along their contacts composed essentially of chlorite and garnets. The line drawn on the map (fig. 2) to represent the approximate contact between the rocks that are igneous and those that are sedimentary in origin, is located on the basis of the structural relations and appearance of the rocks 
in the field, rather than on any difference in texture or mineral composition, and while it is unlikely that there are important masses of altered sedimentary rocks on the east side of the line, there are known to be apophyses or dikes on the west of it. Much vein quartz oceurs as small pieces in the soil derived from the sedimentary schists in the vicinity of their contact with the area of igneous rocks on the east.

The ore-body is apparently continuous for a distance of more than a mile along its course. It is not exposed in the section furnished by the bluffs along Phelps Creek, although nenr the line of its strike much pyrite is present in the schists. Southwest of the Hudgins mine, outcrops are not as plentiful, and it is impossible to say how much farther the orebody extends in that direction. A little prospecting is reported at several places, but nothing of value has been discovered.

DETAILED DESCRIPTION OF THE ORE AND INCLOSING ROCK.

\section{The Margaret Mine.}

The outcrops of the ore-bearing rocks are stained with limonite and more or less porous from the oxidation of sulphides. In places directly above the ore-body there are large outcrops of gossan, consisting of dark brown, porous limonites containing comparatively little silica, and only occasional fragments of decomposed schist. At the Margaret mine, the dark bluishgray schist with phenocrysts of garnet and biotite occur less than 100 feet west of the shaft started in the limonite capping, and pieces of hormblende schist were found lying on the surface only a short distance toward the east. Intermingled with the hornblende schist were found a few pieces of fine-grained quartzite, carrying irregular dark green crystals of hornblende and light greenish-brown needles. of sillimanite. Pieces of rock were also found which appear to be intermediate in mineral composition between the hornblende schists and the quartz-sericite-chlorite schists.

The shaft at the Margaret mine was sunk on top of a ridge abouit 30 to 40 feet above the creek and the limonite ores continued to a depth of 28 or 30 feet, which is approximately the water level, before pyrite was encountered. Pyrite more or less cupriferous is the chief ore-mineral from this point down, but at a depth of about 55 feet it is accompnnied by some chalcopyrite and bornite. The copper sulphides are not very plentiful and seem to be confined to a zone having a vertical thickness of 4 or 5 . feet. In the bottom of the shaft which is about 90 feet deep, pyrite, slightly cupriferous, is the only ore-mineral. Fractures or joints. in the rocks are frequently coated with hyalite, usually white but some- 
times light green from copper stain. The strike of the schistosity is about N. $30^{\circ}$ E. and the dip practically vertical. All the schists exposed in the shaft are more or less impregnated with sulphides; but the distribution is very irregular, the areas of greatest concentration frequently having the appearance of veinlets of pyrite. The schists are cut by occasional small lenticular veins of quartz and feldspar ranging up to 5 or 6 inches in width. The sketch shown in fig. 23 roughly illustrates the structural relations of the ore-deposit and the distribution of the pyrite.

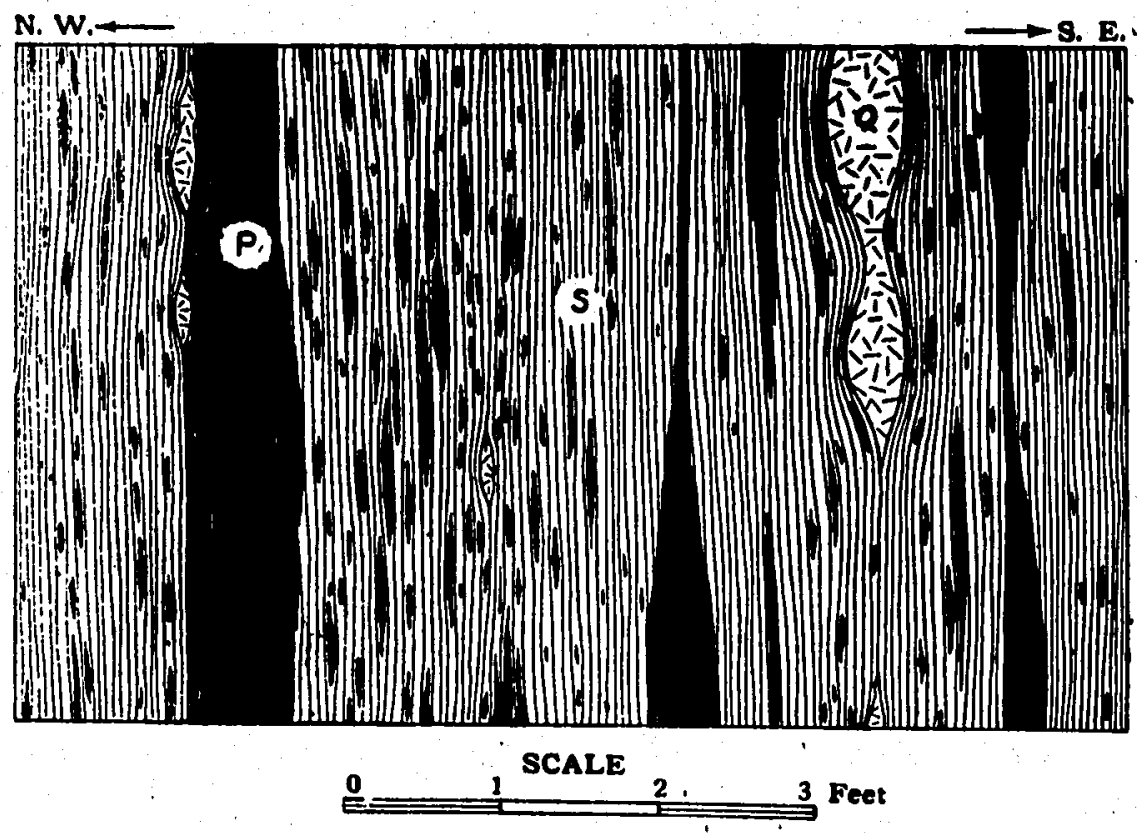

Fig. 23.-Diagrimmatic section showing quartz-feldspar lenses nnd distribution of sulphides in schist at the Margaret Mine. $Q$, quartz-feldspar lens; $S$, schist with a little disseminated pyrite; $r$, chiefly pyrite.

The richest ore consists of 80 or 90 per cent. pyrite, a little white sericite, scattered pink garnets 1 to $1.5 \mathrm{~mm}$. in diameter, a few small flakes of chlorite, and a little quartz. A thin section for microscopic examination was made from a piece of schist.(Spec. 312-C) carrying about 60 per cent. pyrite. In the hand specimens the rock appears to consist almost wholly of slightly cupriferous granular pyrite $(1.5$ to $2 \mathrm{~mm}$. in diameter) and white sericite, with only a few small pink garnets. The distribution of the sulphides is closely related to the schistosity of the rock. 
Near joint planes the sulphides have a dark coating and the white sericite is stained green by the presence of a small amount of copper. Under the microscope the smaller crystals of pyrite frequently show cubical form, but the larger masses have irregular outlines. The sericite is mostly oriented parallel to the schistosity, but many of the flakes look as though they had been pushed aside by the pyrite. Quartz is more plentiful in the thin section than one would suppose from a megascopic examination of the rock. It shows marked optical distortion and slight granulation from crushing, and contains occasional liquid and gaseous inclusions. A little magnetite is present in small grains and is usually closely associated with pyrite.

Another specimen (316) of schist, showing the contact with a quartzfeldspar stringer which cuts across the cleavage and has narrow veinlets of quartz branching off parallel to the schistosity, is a light gray, closetextured rock composed of fine-grained quartz, sericite, chlorite, a little magnetite, and numerous red garnets ranging up to $1 \mathrm{~mm}$. in diameter. Pyrite is plentiful but not abundant, occurring in grains and small lenticular masses elongated in the direction of schistosity; and while disseminated throughout the rock appears to be slightly more concentrated near the quartz veinlets. Under the microscope the quartz grains show irregular internenétrating outlines and wavy extinction. The flakes of sericite and most of the light green chlorite are oriented parallel to the schistosity. The garnets are very ragged in outline and micropoikilitic in texture from numerous inclusions of quartz. In places they show slight alteration to chlorite. Plagioclase feldspars are also present and the minerals magnetite and pyrite are plentiful, frequently showing a close association, with pyrite occurring as inclusions in the magnetite or with the latter surrounded by the former.

'The quartz-feldspar veinlets range up to 6 ' inches or more in width, and are composed essentially of coarsely crystalline quartz, varying from white and translucent to clear and glassy, with more or less feldspar in angular crystals, having sharp straight outlines, ranging up to $i \mathrm{~cm}$. or over in diameter, and white to light yellow in color. In portions of the veinlets feldspar constitutes 10 per cent. or more of the mass while elsewhere it is practically absent. The feldspar crystals occur throughout the vein but are more plentiful near the walls and in places extend for a fraction of $1 \mathrm{~cm}$. into the enclosing schists. Small masses of chlorite and garnet, probably representing inclusions of the country rock, are occasionally present. A little pyrite occurs in the central portions of the veinlets, 
usually along cleavage planes or contacts between feldspar and quartz, but most of it is found near the walls and is yet more abundant in the enclosing schists. In thin section (315) under the microscope, the quartz shows some granulation and marked undulatory extinction, but the feldspars, aside from a slight warping of the cleavage planes, which is visible in the hand specimen, show no pressure effects. The feldspar is a soda-lime plagioclase, chiefly oligoclase-andesine, and usually shows multiple twinning after the albite law, though this appears to be absent in places. $^{a}$ Liquid and gas inclusions, usually arranged in rows or planes, are plentiful in the quartz and occur to a lesser extent in the feldspar.

\section{The McKenna Mine.}

At the McKenna mine the gossan is exposed in the side of the hill just above the shaft, and apparently grades into the enclosing schists. It is said to be only about 8 feet deep in the shaft, which is located not far from the creek and fills with water almost to the surface. Descriptions of the ore-body exposed by the underground workings, and the rock lying on the dump, indicate that the deposit is similar in every way to that at the Margaret mine. It is reported that "peacock" copper ore was struck in the shaft about 35 : feet from the surface, where it. was about 8 feet wide and 6 feet thick. The walls of this secondary copper deposit were fairly well defined, but the large masses of pyrite graded into the country rock without definite walls.

A specimen obtained by Dr. Maynard from the bottom of the shaft, 53 feet from the surface, is darker colored and more chloritic than most of the rock found on the dump or in this vicinity. It is a dark green foliated schist in which chlorite, quartz, biotite, garnet, pyrite, and magnetite are easily distinguished megascopically. In thin section (Spec. 6) plagioclase feldspars can be identified, but as they closely resemble the quartz in index of refraction and do not always show twinning, it is impossible to estimate their relative abundance, though the quartz is probably much in excess. Part of the chlorite gives evidence of its derivation from biotite. A little sericite is also to be seen and a few light brown prismatic crystals, probably of hornblende. Pyrite is abundant and magnetite plentiful, the two minerals being closely associated, with pyrite usually surrounding the magnetite.

aA specimen of this feldspar was submitted to Dr. E. S. Larsen, Jr., for determination by the immersion method. He identified the feldspars as albite-oligoclase to oligoclase-andesine and states that the fresl and dominant feldspar is oligoclaseandesine. The maximum and minimum indices of refraction are: $q=1.535 \pm 0.003$ to $1.541 \pm 0.003$ $\stackrel{\gamma}{r}=1.542 \pm 0.003$ to $1.549 \pm 0.003$ 
Some of the rock on the dump contains a jittle hornblende and probably represents the first stage of the gradation into hornblende schist. It is a light gray schist (Spec. 34) with a greenish tinge, consisting of finegrained quartz, chlorite, sericite, garnets about $1 \mathrm{~mm}$. in diameter, small grains of mngnetite, and much disseminated pyrite, which is partly arranged in irregular planes parallel to the schistosity. The hornblende which is not plentiful occurs in dark green crystals ranging up to 2 or 3 $\mathrm{mm}$. in diameter. Fxamined under the microscope, the smnller garnets have well-defined outlines but the larger ones are usually ragged, and all of them contain included grains of quartz. The magnetite is disseminated in grains and small angular masses showing more or less distinct crystal outline. Pyrite is frequently in contact with magnetite and often occurs in narrow planes or lenses parallel to the schistosity. Small plagioclase feldspars and dark green prismatic crystals of hornblende, with a few grains of titanite, and small inclusions of apatite and zircon, make up the minor accessories.

About 50 yards southenst of the McKenna shaft, a small diabase dike outcrops, but could not be traced any distance. The strike is probably northenst and southwest. It is a medium-grained, dark gray rock with ophitic texture easily recognizable in the hand specimen, and twinning can be seen on the feldspars with the aid of a pocket lens. Pieces of rock found on the dump indicate that a very fine-grained diabase dike, which in places is only $11 / 2$ inches wide, was encountered in the underground workings.

\section{The Johnson Mine.}

At the Johnson mine, the gossan may be seen outcropping in the road 100 yards south of the sliaft, and there is much vein quartz lying on the surface in the same vicinity. A short distance north, there are outcrops of the same knotted schist found on the east side of the ore-body wherever there are exposures. This rock was also encountered in the underground workings, and a thin section was made from a piece of the schist (Spec. 319-A) found on the shaft dump. It is a dark gray, thinly foliated schist with the folia wrinkled by numerous small pseudophenocrysts of garnet and biotite around which they are folded. The garnets are much more plentiful than the biotite crystals, and there is also a little pyrite. Under the microscope the biotite crystals are seen to contain numerous included grains of quartz and in a few instances the flakes are bent or curved, giving the mineral an undulatory extinction. They have no uniform orientation. The ground-mass is composed essentially of quartz and sericite with a little 
chlorite, biotite, and very rarely plagioclase feldspar. The quartz occurs in elongated grains interleaved with fine shreds of sericite, all being perfectly oriented parallel to their greatest dimension. Flakes of sericite in the same vicinity extinguish together except where the folin are bent around the pseudophenocrysts, and there they look as though they had been pushed aside by the mineral in its growtl, forming lenticular eyes, with quartz usually filling the ends of the lenses. Sonı of the eyes contain two crystrals instead of one, though this is not common. A similar rock (Spec. 307) in which the eyes are formed chiefly of biotite instend of garnet, is found at a somewhat greater distance from the granite. It is described on pages 32-33.

Hornblende schist outcrops in the road less than 100 feet south of the gossan, and a microscopic slide (Spec. 458) was made from some of the rock obtained within 200 feet. In the hand specimen it is a finegrained, dark green rock, close-textured and slightly schistose, composed for the most part of hornblende, quartz, and chlorite. Under the microscope the rock is distinctly schistose because of the approximate orientation of the hornblende. 'This mineral is dark green in color, ragged in outline, and only occasionally contains inclusions of the other minerals. The hornblende constitutes about 75 per cent. of the rock mass. Irregular grains of quartz, chlorite, partly if not wholly derived from hornblende, a little plagioclase feldspar, and a few grains of magnetite make up the remaining constituents. In the absence of chemical analyses it is impossible to say whether this rock is igneous or sedimentary in origin, but the manner in which it is interbedded with other schists varying slightly in composition, leads the writer to believe that this schist is more likely derived from a sedimentary rock.

At the mouth of the adit about 150 feet southeast of the Johnson shaft, a fine-grained, dark gray schist is exposed,' in which quartz, chlorite, probably hornblende, magnetite, and pyrite are the only minerals coarse enough for megascopic identification. A thin section (Spec. 319-B) was made from a similar rock found on the dump. In the hand specimen it is a fine-grained, compact rock, gray with a slightly greenish tinge. It is slightly banded and contains a little disseminated pyrite, but most of the minerals are too small for megascopic identification. Under the microscope it is seen to consist of quartz, hornblende, soda-lime feldspar, chlorite, and magnetite, the order given being that of relative abundance. The quartz occurs in clear grains showing no gramulation and little optical distortion. Hornblende is present in ragged individuals with numerous. 
inclusions of quartz and magnetite, and varies in size up to nearly $1 \mathrm{~mm}$. in length. The crystals are uniformly oriented parallel to the schistosity. Plagioclase feldspar (probably andesine) is plentiful, and usually shows albite twinning. The chlorite is light green in color and occasionally shows multiple twinning. Magnetite occurs in small irregular grains uniformly distributed throughout the slide.

Another variety of hornblende schist found on the dump is coarser grained (Spec. 320-A). Megascopically it is a dark green schistose rock containing crystals of green hornblende 1 to $2 \mathrm{~mm}$. in diameter, brown biotite, green chlorite, and occasional brown garnets. In thin section the hornblende is light green in color, very ragged in outline, and contains numerous inclusions of the other minerals, principally quartz. It shows extensive alteration to carbonate and chlorite. The biotite has strong absorption, changing from brown to pale brown or colorless, and in places. it shows alteration to chlorite. Quartz and soda-lime feldspar (andesine) are present in small grains, partly as inclusions in the hornblende and partly filling interstitial spaces. The feldspars usually show albite twinning. Grains of titanite, magnetite, and occasional rutile needles make up the minor accessories.

Descriptions of the ore-body by men who worked in the mine, and the material faund on the dumps, indicate that the ore-deposits at the Johnson mine are essentially the same as at the mines previously described. The ore-body is said to dip toward the northwest at an angle of about $80^{\circ}$. In some of the ore found on the dump pyrite occurs mixed with pyrrhotite and a little chalcopyrite, the gangue minerals being a small amount of quartz and sericite. Fragments from quartz-feldspar veinlets are also present on the dumps. The copper ore that was mined and shipped from this property is said to have consisted chiefly of "rich black copper ore" (chalcocite) found a short distance below the water level, and little or no high-grade copper ore seems to have been found in the lower workings.

\section{The Hudgins Mine.}

The country rock at the Hudgins mine, as indicated by outcrops in the vicinity, is exactly the same as at the other mines described above, and there seems to be no essential difference in the character of the ore-deposit. The material found on the dump is not as heavily impregnated with sulphides as at the Johnson and McKenna mines, and most of the orebearing schist is much lighter colored. Some of the rock closely resembles the quartz-sericite schist at the London and Virginia and Buckingham 
mines. It is a fine-grained, white, lustrous schist in which quartz, sericite, and disseminated pyrite are the only minerals that can be identified with a pocket lens. Other pieces found on the dump are similar but contain a few scattered flakes of biotite.

GENESIS OF THE NEW CANTON ORE DEPOSITS.

The New Canton ores belong to that class of ore-deposits known as contact deposits, and it is believed that the sulphides which occur impregnating the schists near the contact were derived from the mass of intruded igneous rock that lies to the east. Acid igneous rocks on cooling give off a large amount of water in the form of highly heated vapor or gas, and this water may carry minerals in solution and deposit them where the conditions are most favorable. That this has been the mode of formation of the New Canton deposits is indicated by the facts, brought out in the detailed descriptions, which may be summarized as follows:

1. The location of the ores in highly metamorphic schists close to their contact with an acid igneous intrusive.

2. The extensive alteration of the ore-bearing schists with the production of sericite, chlorite, and garnet.

3. The presence of lenses and veinlets of quartz and feldspar, which in places approach pegmatite in composition and appearance.

4. The association of pyrite, chalcopyrite, pyrrhotite, and magnetite as the principal ore minerals.

As has been stated elsewhere in this report, the intrusion of the granite (granodiorite) was accompanied by a partial segregation or concentration of the more basic minerals in the border portions of the cooling magma, and the extensive metamorphism of the sedimentary rock along the contact. The rocks nearest the granite possibly owe their alteration, which resulted in the production of hornblendic rocks, chiefly to heat and pressure, but the alteration of the schists at a somewhat greater distance from the contact, seems to have been due primarily to the heated vapors expelled from the cooling magma. This is indicated by the predominance of the anhydrous minerals, chiefly hornblende, in the rocks nearest the contact; while in the ore-bearing schists, such hydrous minerals as sericite and chlorite were extensively developed. The occurrence of masses of chlorite containing many large garnets, which even under the microscope show no alteration, is difficult to account for if the chlorite was formed entirely as a result of superficial agencies, and, moreover, the inclusions of country rock found in the quartz-feldspar veinlets are all altered to chlorite, biotite, 
and garnet. The same solutions that altered the schists and formed the quartz-feldspar veinlets, deposited the sulphide ores, chiefly pyrite. Some chalcopyrite may have been deposited as a primary mineral at this time, but it seems probable that most if not all of the copper was originally deposited as cupriferous pyrite. The sulphides undoubtedly filled any openings that may have been present, and while the schist may have been injected with veinlets and stringers of pyrite, as with quartz and feldspar, most of the sulphide masses, even where purest, give evidence of formation through metasomatic replacement of the schist.

The frequent association of pyrite and magnetite suggests that the latter was formed by the reducing action of pyrite, since siderite is a prominent constituent in some of the knotted slates a few hundred yards west of the contact. Van Hise has called attention to the development of magnetite from iron carbonate on an extensive scale where igneous rocks have been intruded into ferruginous sedimentaries, and gives the following chemical equation as the probable reaction by which the magnetite is produced :a

$$
2 \mathrm{FeCO}_{3}+\mathrm{FeS}_{2}+2 \mathrm{H}_{2} \mathrm{O}=\mathrm{Fe}_{3} \mathrm{O}_{4}+2 \mathrm{H}_{2} \mathrm{~S}+2 \mathrm{CO}_{2}
$$

'The hydrogen sulphide set free by the reaction would aid in the alteration of the schists by combining with the iron derived from the iron-bearing silicates, and ist. not improbable that the light color of the ore-bearing schists is partly due to the formation of pyrite at the expense of the darkcolored, iron-bearing silicates.

The primary ore consisting chiefly of pyrite, slightly cupriferous, with perhaps more or less chalcopyrite, had a very low copper content. The high-grade copper ore, such as that obtained at the Johnson mine a short distance below water level, owed its formation to concentration through meteoric agencies, of the copper originally present in the upper portion of the ore-body. 'Surface waters, entering the' ore-body by means of small pores, cracks, and joints, carry oxygen and carbon dioxide in solution which react on the sulphides to form copper sulphate and other more or less soluble salts. The copper salts, being more soluble than the iron compounds formed, are mostly leached out and carried farther down, where the copper is reprecipitated by replacing iron in the fresh sulphides below. As a result of these reactions, oxides and carbonates of copper may be present in the upper, oxidized portion of the ore-body, while the rich sulphurets, such as chalcocite, bornite, and chalcopyrite, occur near the

aVan Hise, C. R., A Treatise on Metamorphism, Monograph XLVII, U. S. Geol. Survey, 1004, p. 838 . 
water level, and in the deeper portions of the ore-body only the low-grade, primary sulphides are found.

The practical absence of malachite, azurite, and copper oxide from the oxidized portion of these ore-deposits is probably due to the low copper content of the primary ores, the humid climate, and the long period during which the copper has been suljjected to concentration. The ore-bodjes originally extended much higher above the present surface, and part of the copper contained in the zone of secondary enrichment undoubtedly came from the upward extension of the deposits, which have been removed by erosion during the long period of time which has elapsed since the ores were first formed.

COMPARISON WITH OTHER ORES OF THE DISTRICT.

There is a marked resemblance between the New Canton ores and those at the London and Virginia, and Buckingham mines, the difference being chiefly in the relative proportion of the minerals present. At the latter locality the sulphides, which are apparently not as plentiful, occur chiefly as impregnations in a quartzite instead of a schist, the quarty-feldspar veinlets are more prominent, and the gold content is greater while that of copper is less. The New Canton type of deposit seems to represent one extreme of a gradational series, the typical gold-bearing reins of the district being at the other extreme, with the London and Virginia type intermediate between the two. At the $\mathrm{New}$ Canton mines the secondary ores were, in places, rich enough in copper to pay for their extraction, but these ores can not be expected to extend any great distance below the water level, and it is not believed that the copper content of the primary ores is sufficient to make them of value as a source of that metal. While in places high-grade pyrite occurs in the deposits, the greater portion of the orebody contains a large amount of gangue material, and it is improbable that these mines could be profitably worked at the present time for their. sulphur content alone. 


\section{BIBLIOGRAPHY OF THE GOLD BELT IN THE JAMES RIVER BASIN.}

ANsted, D. T., The Alleghanies and the Gold District of Eastern Virginia, Third Chapter in Scenery, Science, and Art, London, 1854, pp. 277-293.

Becker, G. F., A Reconnaissance of the Gold Fields of the Southern Appalachians, 10th Ann. Rept., U. S. Geol. Survey, 1894.5, pt. iii, pp. 251-331.

Campers, J. L., The Virginia Gold Beit near the Richmond and Alleghany Railway, The Virginias, 1882, vol. iii, pp. 120-121.

- Geology and Mineral Resources of the James River Valley, Virginia, U. S. A., with Map and Geologienl Sections, New York, 1882, pp. 14-10,
00-106, and 112.

Clearsox, T. G., AND Taylor, R. C., The Gold Region of Virginia, Trans. Geol. Soc. Pa., 1835, vol. i, p. 300.

Credner, $H_{\text {, }}$ Report of Explorations on the Gold Fields of Virginia and North Carolina, Amer. Jour. Mng., 1868, vol. vi, pp. 361, 377, 303, and 406.407; 1869 , vol. vii, pp. $9,20-27,42-43,58,72 \cdot 73$, and 105 .

DALE, T. N., Slate Deposits and Slate Industry of the United States, U. S. Geol. Survey, Bull. 275, 1006, pp. 111-115.

DARToN, N. H., Fossils in the "Archean" Rocks of Central Piedmont, Virginin. Amer. Jour. Sei., 1802, vol. xliv, pp. 50-52.

EdiTOR, THE. Reprinted from paper by "The Editor," in the Richmond Enquirer, The Garnet and Moseley Mine, Virginin, The Mining Magazine, August, 1853, No. 2, vol. i, pp. 164-167.

FroemLina, Henry, AND RoBentson, ANDrew, A Hand-Book on the Minerals and Mineral Resources of Virginia, Prepared for the Virginia Commission to the St. Loujs Exposition, Richmond, 1904, $150 \mathrm{pp}$. For gold see pp. 43-52.

Gentr, F. A., Contributions to Mineralogy, Amer. Jour. Sci., 2d ser., 1855, vol. xix, pp. $15-23$; 1850, vol. xxviii, pp. 246-255. Hammow, J, R., The Natural Wealth of Virginia, Harper's Magazine, 1865, vol.

Hanaison, RaNDoLPI, Hand-Book of Virginia, 4th el., p. 50.

Hewwoon, Wá: Joky, Observations on Metalliferous Deposits, Trans. Royal Geol. pp. 371-384.

Hotchkiss, JED, Virginia: A Geographical and Political Summary, Rjchmond, Va., $1870,320 \mathrm{pp}$. For gold see pp. 34-35.

The Resources of the Virginins on and near the Proposed Route of the Richmond and Southwestern Railway, The Virginias, 1880, vol. i, pp. 00-03. vol. ii, p. 85.

Jorsson, W. R., Some Observations on the Gold Formations of Maryland, Virginia, and North Carolina, Proc. Amer. Asso. Adv. Sci., 1850, vol. iv, pp. 20-21.

Locke, A. G., Gold, Its Occurrence and Extraction, New York, 1882, pp. 182-190.

MAURY, M. F., Physical Survey of Virginia: Her Resources, Climate, and Pro. ductions, Richmond, 1878, $143 \mathrm{pp}$. For gold see p. 38

Nitze, H. B. C., AND Wilkens, H. A. J., The Present Condition of Gold Mining in the Southern Appalachian States, Trans. Amer. Inst. Mng. Engrs., 1896, vol. Xxv, pp. 601-790, 1016-1027.

Regions Mining in North Carolina and Adjncent South Appalnchian

vey, Bull. 10, 1807.

, A., Examinations and Explorations on the Gold Belts of the Atlantic Strtes, The Garnet and Moseley Mines, Virginia, Mining Mragazine, 1854, vol. ii,

Pollakd, Thomas, A Hand-Book of Virginia, Richmond, 1879, pp. 16-18, 20, and 102 ; Ibid., 3d ed., Richmond, 1881, pp. 106-107, 120 .

by A. G. Locke, New York, 1882, In "Gold, Its Oecurrence and Extraction," 
Rogers, War. B., Report of the Geological Reconnoissance of the State of Virginia, Made under the Appointment of the Board of Public Works, Richmond, 1830 Republished at Philadelphia, 1830. (See Geology of the Virginias.) Report of the Progress of the Geological Survey for the Year 1830,
Richmond, 1840. (See Geology of the Virginias.)

Richmond, 1841 . (See Geology of the Virginins.)

- Geology of the Virginias. (A Reprint of Annual Reports and Other Papers on the Geology of the Virginias, Edited by Mrs. W. B. Rogers) New York, 1884 .

Srchman, B., Remarks on Some of the Gold Mines, and on Parts of the Gold Region of Virginia, Founded on Personal Observations Made in the Months of August and September, 1830, Amer. Jour. Sei. and Arts, 1837, vol. xxxii, pp. 98-130.

Watson, Thosas L., Mineral Resources of Virginia, Lynchburg, Va., 1907, xxxi+ 018 pp. For gold see pp. 540-507; Copper deposits of Buckingham County, pp. 500.502; The Buckingham-Fluvannn counties slate belt; pp. 42-46. Survey, 1910, pp. 112-113.
Granites of the Southeastern Atlantic States, Bull. 420, U. S. Geol.

ANd Powers, S. L., Fossil Evidence of the Age of the Virginia Piedmont Slates, Amer. Jour. Sci., 1911, vol. xxxi, pp. 33.44

WhIrsey, J. D., Metallic Wealth of the United States, Philadelphia, 1854. For Virginin, see pp. 110, 124-120.

Wrrlisus, G. H., Anatase from the Arronia Slate Quarries, Buckingham County, Virginia, Amer. Jour. Sei., 3d ser., 1801, vol. xlii, p. 431.

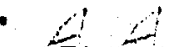

List of Mining Reports and Prospecti.

Johrson AND Mathex; Prospectus of the Garnet and Moseley Gold Mining Co. (Not seen.)

- Prospectus of the London and Virginia Co. (Not seen.)

- Prospectus of the Garnet Gold Mining Co., of Buckingham County, Virginia, New. York, 1852. (Quotes from a letter by E. W. Johnson.)

SNeld, P. A., Report on the Belzora Mine.

Vinarisia Goid, (A prospectus issued by the Hughes Gold Mining and Milling Company),. Roanoke, Va., 1005.

\section{Miscellaneous Notes on Mines in the District.}

The following publications contain occasional notices of gold mines in : Virginia and have been consulted in the preparation of this report:

American Journal of Mining.

Engineering and Mining Journal.

Mineral Industry.

Mineral Resources of the United States.

Mining and Scientific Press.

Mining Journal.

Mining Magazine.

Reports of the Director of the United States Mint on the Production of Precious Metals in the United States.

United States Census Reports.

Thas Virginias. 


\section{N D E X}

Acknowledgments, 1.

Age, diorite dikes, 84.

granites, 54.

greenstone schists, 40.

ore-deposits, $233-234$.

Annconda copper mine, 243-244.

Descriptive geology, 244.

History, 243-244.

Locntion, 243.

Annconda gold mine, $50 \cdot 51$.

Annlyses, vein and wall rock, Young American Gold mine, 124 . partial, ore, Tellurium mine, 161.

Analysis of tetradymite from Tellurium mine, 160

Anderson mine, 105.

Description, 105.

Location, 105.

Annual production of gold, 200.

Arvonin, 44-45.

Atmore, Kent, and other properties, 142.

Ayre tract, 20-21.

Ballinger Creek, 52-53.

Belzoro mine, 30, 139-141.

Descriptive geology, 140-141.

History, $130 \cdot 140$.

Location, 139.

Production, 141

Benton mine, 85, 152 .

Descriptión, 152:

Location, 152.

Berthar and Edith mine, 38-39, 142-144.

Description of veins and country rock, $143-144$

History, 142-143.

Iocation, 142.

Bibliography of the gold belt in the Tames River Busin, 260-261.

Big Byrd Creek, 35-36, 08-69, 79-80.

Bluffs along James River, 45.

Bondurant mine, 26, 192-195.

Descriptive geology, 193-105.

History, 102.103

Iocation, 102.

Bowles bridge, 38.

Bowles mine, 85, 175, 178.179.

History and general description, 175.

Location, 175.

Bremo Bluff, 16-18, 52 .

Buckinghnm County, mines in (See Mines in Buckingham County).

Buckingham mine, 190.191.

Geology of the ore-vody, 101.

History, . 100-101.

Location, 190.
Juln, 61.

Bumpus property, 243.

Burnett nine, 108.

Descriptive geology, 100.

History, 106.

Jocntion, 106.

Busby mine, 140-147.

Cambrian, 115, 116.

Cambrian or post-Cambrian, 84-85. Diorite dikes, 84.

Cartersville, 56.

Curtersville uren, 54-506.

Detuiled descriptions, $\mathbf{5 5 - 5 0}$.

General description, $54-55$.

Carysbrook, 41-42, 45.46, 75-77.

Cinrysbrook bridge, 75 .

Classification, general, 14.

Climate, 4.

Collins mine, 141

Columbia, 64-68, 86.

Columbia area, 62-67.

Detniled descriptions, 64-77.

General description, 62-04.

Comparison with other ores of the distriet, 250 .

Conglomerate, 40-42.

Detrils of occurrences, 41-42.

General character and distribution, $40 \cdot 41$.

Contact metamorphism, 100.

Country rock, $170-177$.

Cuiture, 4.

Cyanite schists, 26-20.

Detnils of occurrences, $27-20$.

General character and distribution, 26.27.

Genesis, 24

Deposition of the ores, 221-222.

Description of Anderson mine, 195.

Belzoro mine, 152.

Flood mine, 105.

gangue minerals, 213 214.

ore minerails, 214-215.

ores, Morrow mine, 204205.

vein, Iondon and Virginil mine, $187-100$.

veins and country rock,

Bertha and Edith

mine, 143.144.

IVilliams mine, 101-102.

Description of copper mines and pros. pects, 241-259.

Description of individanl mines, 241 . 240

Anaconda mine, 243-244. 
Descriptive geology, 244.

History, 243.244.

Locntion, 243.

Bumpus property, 243.

Ford property, 243 .

Genesis of ores, Lightfoot and Anaconda mines, $244-246$.

Lightfoot mine, 241-243.

Country rock, 241-242.

History, 241

Joention, 241.

Ore-deposit, 242-243.

New Canton mines, 246-250.

Comparison with other ores of the district, 259 .

Detniled description of the ore aml inclosing rock, 250-257.

Hudgins mine, 256-257.

Johnson mine, 254-250.

McKenna mine, 253-254.

Margaret mine, 248.

General description of the geology, 248.250.

Genesis of the New Canton ore deposits, $257-250$

History, 246-248.

Hudgins mine, 248.

Johnson mine, 247 .

Mclienna mine, 247.

Margaret mine, 248.

Types of copper deposits, 241.

Description of -individual copper mines, 241-240.

Anaconda mine, 243-244.

Bumpus property, 243.

Ford property, 243.

Genesis of ores, Lightfoot and Anu. condn mines, 244-246.

Lightfoot mine, 241.243.

Descriptive geology, Annconda mine, 244. Belzoro mine, 140 . 141.

Bondurant $\mathrm{mine}$, $193-195$.

Burnett mine, 190.

London and Virgin.

ia mine, 184-187.

Morrow mine, 200204

Moss mine, $14 \overline{5}$.

Waller mine, 148. 151.

Descriptive geology and petrogrnphy, 1387.

Introduction, 13.

Rocks igneous in origin, 47-87.

Cambrian or post-Cambrian, $84-85$.

Diorite dikes, 84 . Age, 84.
Detrils of oceurrences, 84-85.

Benton mine, 85.

Bowles mine, 85 .

long Island Creek, 85.

Pulinyra, 84-85.

Distribution and general character, 84 .

Genernl classification, 47.

Pre-Cambrian, 47-53.

Greenstone schists, 47-51.

Age, 40.

Detnils of occurrences, $49 \cdot 51$.

Anncondn mine, 50-51.

Hughes mine, 51.

Lightfoot farm, 50.

Palmyra, 51.

Shores, 51 .

Slate River, 40-50.

Quartz-feldspar porphyries, 51-52. Rhyolites, 52-53.

Detnils of occurrences, 52.53.

Ballinger Creek, 52-53.

Bremo Bluff, 52.

Palmyra, 53.

Slate River, 52.

General description and age relations, 52 .

Pre-Cambrian and Cambrian, 53-84.

Granites, their associnted pegmatites and ho rnblende schists, 53-82.

Age, 54.

Cartersville area, 54-50.

Detailed descriptions, $54-50$ Cartersville, 50.

Pemberton, 55-50.

Stokes, $\mathbf{5 0}$

General description, 54-55.

Columbia area, 82-77.

Detriled descriptions, $04-77$.

Big Byrd Creek, 68-60.

Carysurook, 75-77.

Carysturook bididge, 75 .

Columbin, 64-68.

Fork Union, 73 .

Iantana, 60 .

New Canton, 71-72.

Payne farm, 70-71.

Rivanna Mills, 73-75.

Stenrnes, 72-73.

'Tubscott, 70.

Trent furm, 71 .

Trenton Mills, 71 .

General description, 02-64.

Elk Hill complex, 57.59.

Detailed descriptions, 57-59.

General description, 57.

Gold Hill granite aren, $7 \overline{7}-80$.

Detniled descriptions, 78-80. 
Big Byrd Creek, 70-80. Hughes farm, 80 .

McGloam mine, $78 \cdot 70$

General description, 77 .

Granite at Greeley mine, 82

Introductory statement, 53-54.

Pegmatite belt, 50-02.

Detailed descriptions, 59-62.

Buln, 61 .

Dickey farm, 01 .

James River section, 50-60

Lantana, 61.

Little Byrd Creek, 00.61.

Other localities. 62.

Shannon Hill, 61.

General description, 50 .

Rosney granite area, $\mathbf{8 0 - 8 2}$.

Porphyries, 82-84.

Details of occurrences, 82-84.

Distribution and general description, 82 .

Triassic, $\mathbf{8 5} \cdot 87$

Diabase dikes, 85-87.

Details of occurrences, 80.87 .

Columbia, 86 .

Dillwyn, 87.

Grannison mine, 80 .

Other localities, 87

Pemberton, 87.

Rocks sedimentary in origin, 14-4T.

General classification, 14

Ordovician, $30 ; 46$

Conglomerate, 40-42.

Details of occurrences, 41-42.

Carysbrook, 41-42.

Long Island Creek, 42.

Penlan, 41 .

General character and distribu. tion, 40-41.

General statement; $30-40$.

Quartzite, 42

Schist, 42-43.

Slate, 43-46.

Details of occurrences, 44-40. Arvonia, 44-45.

Bluffs along James River, 45

Carysbrook, 45-40.

General character and distribu.

Tuff, 43 tion, 43-44.

Pre-Cambrian, 14-39.

Cyanite schists, 26-29.

Details of occurrences, 27-20.

Trent farm, 28.29.

Willis Mountain, 27-28.

General character and distribu. tion, 20-27.

Genesis, 27.

Ferruginous quartzite, $19-22$.
Detnils of occirrences, 10-22.

Ayre tract, 20.21.

Other locnlities, 21-22.

Scotin mine, 21 .

Tiebl trinct, 10.20.

Genernl charneter and distribution, 10.

Garnetiferous quartzites, 22-23.

Details of oceurrences, 22-23.

Lantamu, 22-23.

Stage Junction, 23.

General character and distribu. tion, 22.

- General statement, 14-15.

Gneisses, 30-30.

Details of occurrences, 38-39.

Belzoro mine, 30.

Bertha nnd Edith mine, 38 . 30:

Bowles bridge, 38

Foung Amerienn mine, 38.

General chnracter and distribu. tion, 30-3i.

Genesis, 37 .

Hornblende-bearing quartzites, 23.

Hornblende schists, 34-36.

Details of occurrences; $35-30$.

Big Byrd Creek, 35-30.

Lantana, 36.

New Canton, 35.

General cliaracter and distribution, 34-35.

Knotted schists, 29-34

Details of occurrences, 30-34.

New Canton, 30-34.

Stage Junction, 34

Strathmore, 34.

Tellurium schists, 34

General character and distribution, 20.30.

Quartzite, 15-19.

Details of occurrences, 16-10.

Bremo Bluff, 16-18.

London and Virginia mine, 10.

Tellurium mine, 18-10.

General character and distribution, $15-10$

Quartz-sericite schist, 23-20.

Details of occurrences, 24-20.

Big Byrd Creek, 24.

Bondurant mine, 26.

Lantana, 24-25.

London and Virginia mine, 25.20.

New Canton-Dillwyn road, 25

Other localities, 20. 
General character and distribu. Genesis, 24 .

Trinssic, 46-47.

Detailed description, ore and inclosing rock, $250-257$.

Cartersville area, 55.57.

Columbir aren, 64$7 i$.

contact phenomena, 107-114.

Elk Hill complex, 57.59 .

Gold Hill granite area, $\mathbf{7 8 - 8 0}$.

pegmatite belt, 50 .

62.

Tellurium vein sys-

tem, $157-172$.

veins and wall

rock, $157-172$.

Young American

mine, 122-139.

James River section across granite contret, $107-112$.

Rivanna River, section across granite Veins, 113 .

Willis Mountrin, 113-114.

Details of occurrences, conglomernte, 40 . $-42$.

cyanite schists, $27-29$.

diabnse dikes, 80 . 87.

diorite dikes, 8485.

ferruginous quartz. ite, 10-22.

garnet'f' $\mathbf{1}^{\prime}$ 's quartz. ites, 22-23.

gneisses, 38-30.

greenstone schists, 40-5̄.

hornblende schists, 35-36.

knotted schists, 30-34.

porphyries, 82-84.

quartzite, $16-10$.

rhyolites, $52-53$.

slate, 44-46.

quartz-sericite schist, 24-20.

Diabaso dikes, $85-87$.

Details of occurrences, 80.8\%.

Distribution and general charneter, 85-86.
Dickey farm, 61

Dillwyn, 87.

Diorite dikes, 84 .

Age, 84.

Detnils of occurrences, 84-85.

Distribution and general character 84

Drainage, 3.4, 91.03.

Elk Hill complex, 57-50.

Detailed descriptions, 57-59.

General description, 57.

Equipment, Hughes mine, 181-182.

Faulting, 100.

Ferruginous quartzite, 10.22.

Details of occurrences, 10-22.

General character and distribution, 10.

Fleming mine, 151

History and description, 151.

Location, 151.

Flood mine, 105.

Description, 105.

Location, 105.

Folding, 08.09.

Ford property, 243.

Fork Union, 73.

Garnetiferous quartzites, 22-23.

Details of occurrences, 22-23.

General character and distribution, 22.

General character and distribution: conglomerate, 40-41.

cyanite schists, 26-27.

diabaso dikes, $85 \cdot 86$.

diorite dikes, 84 .

ferruginous quartzite, 10

garnetiferous quartzites, 22 . gneisses, 36-37.

greenstone schists, $47-40$.

hornblende schists, 34-35.

knotted schists, 20-30.

quartzite, 15-16.

slate, 43-44.

General conclusions as to the origin of the gold deposits, 231-232.

General description, Curtersville a rea, 54-55.

Columbia, aren, 6264.

Elk Hill complex, 57.

geology, 248-250

geology, Young A. merican mine, 120 . 122.

Gold Hill granite area; 77 .

veins and country rock, Tellurium system, 155.15̄7. 
Genernl description and age relations, jhyolites, 52.

General stritement, Ordovician, 39-40.

Genesis, cyanite schists, 27 . Pre.Cambrian, 14 gneisses, $3 \mathbf{7}$. quartz-sericite schist, 24.

Genesis of the deposits, 216-232.

Deposition of the ores, 221-222.

General conclusions as to the origin of the gold deposits, 231-232.

Nature of the solutions, $217-210$.

Origin of the sprees occupied by the veins, 222-231.

Source of the materinl, 210-221.

Genesis of the New Cunton ore deposits, $257-250$.

Genesis of ores, Jightfoot and Annconda mines, 244-240.

Genetic relations of the gold deposits, 208-234.

Age of the ore-deposits, 233-234.

Genesis of the deposits, 210-2n2

Deposition of the ores, 221-222.

General conclusions is to the origin of the gold deposits, 231-232.

Nature of the solutions, 217-210.

Origin of the spaces occupied by the veins, 222-231.

Source of the material, 210-221. .

Introductioń? 208.209.

Previous theories, 208-209.

Types of deposits, 200.

Afineral composition of the veins, 200216.

Description of the gangue minerals, 213-214.

Description of the ore minerals, 214-215.

List of minernls in the gold veins of the James River basin area; 211.212 .

Summary, 215.216.

Secondary enriclument, 232-233.

Geography and history, 2-12.

Climace, 4.

Culture, 4.

Drainage,' 3-4.

History, $\mathbf{5} \cdot \mathbf{9}$.

Iocation, 2-3.

Previous geologic work, 9-12.

Production, 8.

Soil, 4.

Topography, 3.

Geology, Anaconda mine, 244.

Bondurant mine, 193-105.

Buckingham mine, 101.

Burnett mine, 190.

Hughes mine, 182-183.
London and Virginia mi ne, 184-18i.

Morrow mine, 200-204.

Snead mine, 180-1s1.

Geology of veins and country rock, Hughes mine, 182-183.

Gilliam mine, 105.

Gold Hill grunite aren, $77-80$.

Detailed descriptions, $78-80$,

General description, 62-64.

Gold Hill vein system, 170-170.

Bowles mine, 178.179.

Country rock, $176-175$.

Introduction, 170 .

McGlonm mine, 177-178.

Shaw mine, 178.

Gold mines of the district, 118.208.

Introduction, 118.

Mines in Buckinghnm County, 183 . 207.

Anderson mine, 195.

Description, 105.

Jocntion, 1!n.

Bondurant mine, 192-185.

Descriptive geology, 193-195.

History, 192-193. .

I.oention, 102.

Buckingham mine, 100-191.

Geology of the ore-body, 101.

History, 100-101.

Location, 190.

Burnett mine, 196

Descriptive geology, 196.

History, 196.

Location, $10(6$.

Flood mine, 105.

- Description, 105.

Iocation, 105.

Gilliam mine, 195.

Greeley mine, 205.207.

History, 205-206.

Jocntion, 205.

' Veins and country rock, 200.207.

Hobson tract, $19 i$.

Jight font mine, 207.

Gold veins, 207

History, 207.

Location, 207 .

London and Virginia mine, 183-100.

Description of vein, 187-190.

Descriptive geology, 184-18i.

History, 183-184.

Locution, 183.

Morrow mine, 198-205.

Description of ores, $204-205$.

Descriptive geology, 200-204.

History, 108.101.

Location, 198.

Placers, 205. 
Production, 190-200.

Undergroumd development, 200.

Morton inine, 107-108.

Geology, $197-108$.

History, 197.

Iocntion, 107.

Seny mine, 205.

Williams mine, 101-102.

Description, 101-102.

Locntion, 191.

Mines in Goochlnnd and Fluvnumn counties, 118-183.

Atmore, Kent, and other properties, 142.

Belzoro mine, 130-141.

Descriptive geology, 140-141.

History, 130-140.

Location, 139.

Proluction, 141.

Benton mine, 152.

Deseription, 152.

- Iocntion, 152

Bertlin and Edith mine, 142-144.

Description of veins and country rock, 143.144.

History, 142-143.

Location, 142.

Bowles mine, 175.

History and general description, 172-173.

Locntion, 175.

Busby minie, 146.147 .

Collins mine, 141 .

Fleming mine, 151 .

History ani description, 151.

Ioention, 151 .

Gold Hill vein system, 170-179.

Bowles mine, 178-179.

Country rock, 170-177.

Introduction, 170.

Medloam mine, 177-178.

Shaw mine, 178.

Gold prospects southwest of the Scotin mine, 173-175.

Grnnnison mine, 142.

Hughes mine, 181.183.

Equipment, 181-182.

Geology of veins and country rock, 182-183.

History, 181 .

Location, 181.

Underground development and description of veins, 182.

Morgan mine, 141-142.

Moss mine, 144-140.

Descriptive geology, 145 .

History, 144-145.

I.ocation, 144

Page mine, 170-180.
Payne trinet, 147 .

Pryor tract, 144.

Seotin mine, 172-173.

History und description, 172-173.

Location, 172 .

Shamon Hill, 151-152.

Snend mine, 180-181

Geology, 180-181.

History, 180.

Jocrition, 180.

Tellurimm mine, 152.155 .

History and description, 153-155.

I.ocation, 152.

Present underground develop. ment, 155 .

Tellurium vein system, 155-172.

Detailed descriptions of veins and wall rock, 157-172.

Genernl deseription of veins and country rnek, $155 \cdot 157$.

Waller mine, 148.151.

Descriptive geology, 148-151.

History, 148.

Iocntion, 148

Young American mine, 118.139.

Detailed descriptions of the veins and wall rock, 122-139.

Genernl description of the geology, 120-122.

History, 118-110.

Iocation, 118.

Present equipment, 110.

- Underground levelopment, 119 120.

Gold prospects southwest of the Scotin mine, 173-175.

Gold veins, Lightfoot mine, 207.

Goochland and Fluvanna counties, mines in, (See dlines in Goochland and Fluvanna conntios).

Gineisses, 36-39.

Details of occurrences, 38.39 .

General character and distribution, $36-37$.

Genesis, 37.

Granite at Greeley mine, 82

Grannison mine, 86, 142:

Greeley mine, 205-207.

History, 205.200.

Iocntion, 205.

Veins and country rock, 200-207.

Greenstone schists, 47-51.

Age, 49.

Details of oceurrences, 49)-51.

Anaconda mine, 50-51.

Hughes mine, 51.

Lightfoot farm, 50.

Palmyra, 51.

Shores, 51. 
Slate River, 49-50.

History, 5-0.

Anaconda mine, 243-244.

Belzoro mine, 139-140.

Bertha and Edith mine, 142. 143.

Bondurant mine, 102-103.

Buckingham mine, 190-101.

Burnett mine, 106.

Greeley mine, 205-200.

Hughes mine, 181.

Lightfoot mine, 207, 241 .

London and Virginia mine, 183. 184.

Morrow mine, 198-100.

Morton mine, 197.

Moss mine, 144-145.

New Canton mines, 246-247.

Snead mine, 180.

Waller mine, 148.

Young American mine, 118-119.

History and description, Bowles $\mathrm{m}$ in e 172-173.

Fleming $\mathrm{m}$ ine, 151.

Scotia mine, 172-173.

Tellurium mine, 153-155.

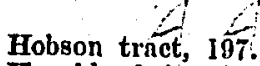

Fornblende-bearing quartzites, 23.

Hornblende scliists, 34-36.

Details of occurrences, 35-36.

General character and distribution. 34-35.

Hudgins mine, 248, 250-257.

Hughes farm, 80.

Hughes mine, 51, 181-183.

Equipment, 181-182.

Geology of veins and country rock, 182-183.

History, 181.

Location, 181.

Underground development and description of veins, 182.

Introduction, 1 .

acknowledgments, 1

contact metamorphism, 106 .

descriptive geology and petrography, 13.

genetic relations of the gold deposits, 208-200.

Gold Hill vein system, 176 .

gold mines of the district; 118.

physiography, 88.

structure and metamorphism, 08

tellurium vein system, $\mathbf{1 5 5}$.

Introductory statement, granites, etc., $53-54$.
James River section, 50-60.

James River section ncross granite contact, 107-112.

Johnson mine, 24i, 254.256.

Jointing, 100 .

Knotted schists, 20-34.

Details of occurrences, 30-34.

General character and distribution 29-30.

Lantana, 24-25, 36, 61, 60.

Lightfoot farm, $\mathbf{6 0}$.

Lightfoot mine, copper, 241-243.

Country rock, 241-242.

History, 241.

Location, 241.

Ore-denosit, 242-243.

Lightfoot mine, gold, 207.

Gold veins, $20 \%$.

History, 207.

Iocation, 207.

Iist of minerals in the gold veins of the James River basin area, 211. 212.

Little Byrd .Creek, 60.61.

Location, Annconda mine, 243.

Anderson mine, 185 .

Belzoro mine, 152.

Benton mine, 152.

Bertha and Edith mine, 142.

Bondurant mine, 102.

Bowles mine, 175 .

Buckingham mine, 100.

Burnett mine, 180 .

Fleming mine, 151 .

Flood mine, 195.

Greeley mine, 205.

Hughes mine, 181.

James River basin gold belt, 2-3.

Lightfoot mine, 207, 241.

London and Virginia mine, 183.

Morrow mine, 198.

Morton mine, 197.

Moss mine, 144.

Scotia mine, 172

Snead mine, 180-181.

Tellurium mine, 152

Waller mine, 148.

Williams mine, 101.

Young American mine, 118.

London and Virginia mine, 19, 25-26, 183-180.

Description of vein, 187-190.

Descriptive geology, 184-187.

History, 183-184. .

Location, 183.

Long Island Creek, 42, 85

McGloam mine, 78-70, 177-178. 
MoKenna mine, 247, 253-254.

Margaret mine, 248.

Metamorphic fentures. 105-114.

Contact metamorphism, 106.

Regional metamorphism, 105-106.

Mineral composition of the veins, 200 . 216.

Description of the gangue minerals, 213-214.

Description of the ore minernls, 213 . 214.

List of minerals in the gold veins of the Jnmes River basin, 211. 212.

Summary, 215-216.

Mines in Buckingham County, 183-207.

Anderson mine, 105.

Bondurnt mine, 102-195.

Buckingham mine, 100-101.

Burnett mine, 100

Flood mine, 195.

Gillinm mine, 185.

Greeley mine, 205-207.

Hobson tract, 107.

Lightfoot mine, 207

London and Virginia mine, 183-190.

Morrow mine, 198-205.

Morton mine, 197-108.

Seny mine, 205.

Williams mine, 191-102.

Mines in Goochland and Fluvanna counties, 118-183.

Atmore, Kent, and other properties, 142.

Belzoro mine, 130-141.

Benton mine, 152.

Bertha and Edith mine, 142-144.

Bowles mine, 175 .

Busby mine, 146-147.

Collins mine, 141 .

Fleming mine, 151 .

Gold Hill vein system, 170-170.

Gold prospects southwest of the Scotia mine, 173-175.

Grannison mine, 142.

Hughes mine, 181-183.

Morgan mine, 141-142.

Moss mine, 144-146.

Page mine, 170-180.

Payne tract, 147.

Pryor tract, 144.

Scotia mine, 172-173.

Shannon Hill, 151-152

Snead mine, 180-181.

Tellurium mine, 152-155.

Tellurium vein system, 155-172.

Waller mine, 148-151.

Young American mine, 118-139.

Morgan mine, 141-142.
Mrorrow mine; 108-205.

Description of ores, $204-205$.

Descriptive geology, 200-204.

History, 108-100.

Location, 108.

Placers, 205.

Production, 109-200.

Underground development, 200.

Morton mine, 107-108.

Geology, 107-108.

Historv, 107.

Location, 197.

Moss mine, 144-146.

Descriptive geology, 145.

History, 144-145.

Locntion, 144.

Nature of the solutions, 217-210.

New Canton, 30-34, 35, 71-72.

New Canton-Dillwyn road, 25

New Canton mines, 240-250.

Comparison with other ores of the district, 259.

Detailed description of the ore and inclosing rock, 260-257.

General description of the geology, 248-250.

Genesis of the New Canton ore deposits, $257-250$

History, 246-247.

Ordovician, 30-40, 110

Conglomernte, 40-42.

General statement, $30 \cdot 40$.

Quartzite, 42.

Schist, $42-43$.

Slate, 43-40.

Tuff, 43.

Ore deposit, Lightfoot mine, 241

Origin of the spaces occupied by the veins, 222-231.

Other localities, 62,87 .

quartz-sericite schists, 20.

ferruginous quartzites, 21-22.

Outline of geological history, 114-117.

Cambrian, 115.110.

Ordovician, 110.

Pre-Cambrian, 115

Trinssic, 116-117.

Page mine, 170-180.

Palmyra, 51, 53, 84-85.

Payne farm, 70-71.

Payno tract, 147.

Pegmatite belt, 59-62.

Detailed descriptions, 59-62.

General description, 59.

Pemberton, 55-56, 87.

Penlan, 41.

Physiographic history, 03-07.

Physiography, 88.97.

Drainage, 91-83. 
Introduction, 88.

Physiograplic history, 03-07.

Relief, 88-91.

Plncers, 235-240.

Porpliyries, 82-84.

Detnils of occurrences, 82.84.

Distribution and general deseription, 82.

Pre-Cambrian, 14-3D, 47-53, 115.

Cynnite schists, 20-20.

Ferruginous quartzite, 10-22:

Garnetiferons quartzites, 22-23.

General statement, 14-15.

Gneisses, 30-30.

Greenstone schists, $4 \overline{7}-\tilde{n}$ l.

Horneblende-benring quartzites, 23.

Hornblende schists, 34-36.

Knotted schists, 20-34.

Quartz-feldspar porphyries, 51-52.

Qunarzite, $150-10$.

Quartz-sericite schist, 23-26.

Rliyolites, 52-53.

Pre-Combrinn and Cambrian, 53-84.

Granites, their nssocinted pegmatites

and hornble

Present equipment, Young $A$ m e ri c a n mine, 110.

Present underground development, 155.

Previous geologic work, 0-12.

Previous thénries; 208-209.

Production, 0.

Belzoro mine, 141

Morrow mine, 109-200.

Pryor tract, 144.

Quartz-feldspar porplyyries, $51 \cdot 52$.

Quartzite, 15-10, 42.

Details of occurrences, 10-10.

General character and distribution, $15 \cdot 10$.

Quartz-sericite schists, 23-20.

Details of occurrences, 24.26 .

Gencral character and distribution, 23-24.

Genesis, 24

Regional metamorphism, 105-106.

Relations of the holnblencle schists to

Relief, 88-91. the granites, 103-105.

Rhyolites, $52 \cdot 53$.

Detuils of occurrences, 52-53.

General description and age relations, 52.

Rivanna Mills, $73 \cdot 75$.

Rivama River section neross granite conitnet, 112-113.

Rocks igneous in origin, $47-87$.

Cambrian or post-Cambrian, 84-85.

General clnssification, 47.
Pre-Cambrian, 47-53.

Pre-Cambrian and Cambrian, 53-84.

Trinssic, $85 \cdot 87$.

Rocks sedimentary in origin; $14-47$.

General classification, 14.

Ordovician, 30-40.

Pre-Cimbrinn, 14-30.

Trinssic, $40-47$.

Rosney granite aren, $\mathbf{8 0 - 8 2 .}$

Schist, 42-43.

Schistosity, 101.102.

Scotin mine, 21, 172.173.

History and description, 172-173.

Locntion, 172.

Seay mine, 205.

Secondnry enrichment, 232-233.

Shannon Hill, 61, 151-152.

Shaw mine, 178.

Shores, 51.

Slate, 43.46 .

Details of occurrences, $44 \cdot 46$.

General character and distribution, 43-44.

Slate River, $40-50,52$.

Snend mine, $180-181$.

Geology; 180-181.

History, 180.

Location, 180.

Soil, 4.

Source of the material, 210-221.

Stage Junction; 34 .

Stenrnes, $72 \cdot 73$.

Stokes, 50.

Struthmore, 34.

Structure and metamorphism, 98-117.

Introduction, 98.

Outline of geological history, 114-117. Cumbrian, 115.110.

Ordovician, 116.

Pre-Cambrian, 115.

Triassic, 116-117.

Metomorphic features, $105-114$.

Contact metamorphism, 100 .

Detniled descriptions of contnet phenomenn, 107-114.

James River section. a cross granite contact, $107 \cdot 112$.

Rivanna River section a cross granite contuct, $112-113$.

Veins, 113.

Willis Mountain, 113-114.

Regional metrumorphism, 105-100.

Structurnl fentures, 08-105.

Faulting, 100 .

Folding, 98-99.

Jointing, 100.

Relations of the lornblende schists. to the granites, 103-105.

Schistosity, 101-102. 
Structural relations of the granite, $102-103$.

Structurnl fentures, 08-105.

Faulting, 100.

Folding, 98-00.

Jointing, 100 .

Relntions of the hornblende schists to the granites, 103-105.

Schistosity, 101-102.

Structurni relntions of the granite, 102-103.

Structural relations of the granite, 102 103.

Summary, 215-210

Tabscott, 70.

Tellurium mine, 18-10, 152-155.

History and description, 153-155.

Locntion, 152.

Present underground development, 155.

Tellurium schists, 34.

Tellurium vein system, $155-172$.

Detailed descriptions of veins and wall rock, $157-172$.

General description of veins and country rock, $155-157$.

Topography, 3.

Trent farm, 28-20, 71 .

Trenton Mills, 71 .

'Triassic, 40-47, 8ī-87, 116-117.
Tuff, 43.

Types of copper deposits, 200, 241.

Underground development, Morrow mine, 200.

Young Amerieni in ine, 110.120 .

Underground development and descripVeins, 113.

Veins and country rock, Greeley mine, $205 \cdot 207$.

Waller mine, 148-151.

Descriptive geology, 148-151.

History, 148.

Jocation, 148.

Webb tract, 10-20.

Williams mine, 181-102.

Description, 191-192.

Location, 191

Willis Mountrin, 27-28, 113-114.

Young Americnn mine, 38, 118-139.

Detailed descriptions of the veins and wall rock, 122-130.

General description of the geology. $120 \cdot 122$.

History, 118-119.

Location, 118.

Present equipment, 110.

Underground development, 110-120. 